$$
\text { UNIVERSIDADE DE SÃO PAULO }
$$

FACULDADE DE FILOSOFIA, LETRAS E CIÊNCIAS HUMANAS PROGRAMA DE PÓS-GRADUAÇÃO EM HISTÓRIA ECONÔMICA

\author{
ANDRÉ LUIZ LANZA
}

De Braços para a Lavoura a Proprietários Rurais: Imigrantes e Acesso à Terra em São Paulo, 1886-1920

Versão corrigida

SÃO PAULO

2021 
Prof. Dr. Vahan Agopyan

Reitor da Universidade de São Paulo

Prof. Dr. Paulo Martins

Diretor da Faculdade de Filosofia, Letras e Ciências Humanas

Profa. Dra. Maria Cristina Correia Leandro Pereira Chefe do Departamento de História

Prof. Dr. Dario Horácio Gutiérrez Gallardo Coordenador Do Programa de Pós-Graduação em História Econômica 


\title{
De Braços para a Lavoura a Proprietários Rurais: Imigrantes e Acesso à Terra em São Paulo, 1886-1920
}

\author{
Versão corrigida
}

Tese apresentada ao Programa de PósGraduação em História Econômica da Faculdade de Filosofia, Letras e Ciências Humanas da Universidade de São Paulo como requisito parcial para a obtenção do título de Doutor em Ciência.

Área de concentração: História Econômica

Orientador: Prof. Dr. Renato Perim Colistete 
Autorizo a reproduçào e divulgaçào total ou parcial deste trabalho, por qualquer meio convencional ou eletrônico, para fins de estudo e pesquisa, desde que citada a fonte.

Catalogaçào na Publicação

Serviço de Biblioteca e Documentaçào

Faculdade de Filosofia, Letras e Ciências Humanas da Universidade de Sào Paulo

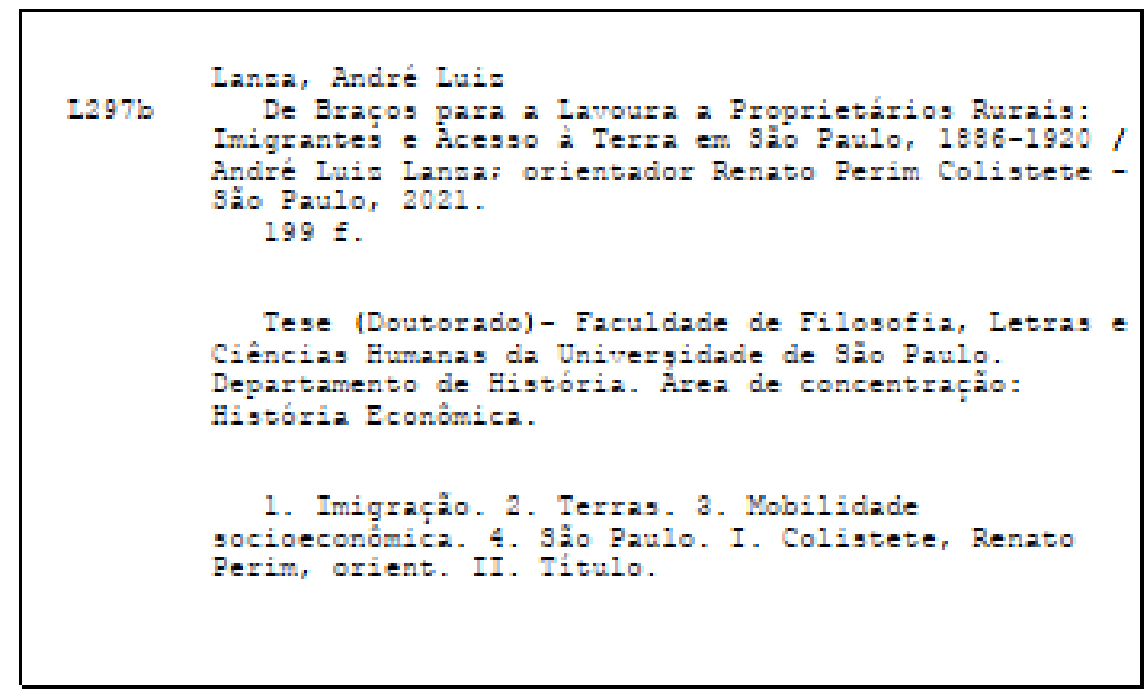




\section{ENTREGA DO EXEMPLAR CORRIGIDO DA DISSERTAÇÃO/TESE}

\section{Termo de Ciência e Concordância do (a) orientador (a)}

Nome do (a) aluno (a): André Luiz Lanza

Data da defesa: $30 / 04 / 2021$

Nome do Prof. (a) orientador (a): Renato Perim Colistete

Nos termos da legislação vigente, declaro ESTAR CIENTE do conteúdo deste EXEMPLAR CORRIGIDO elaborado em atenção às sugestões dos membros da comissão Julgadora na sessão de defesa do trabalho, manifestando-me plenamente favorável ao seu encaminhamento e publicação no Portal Digital de Teses da USP.

São Paulo, 22/6/2021

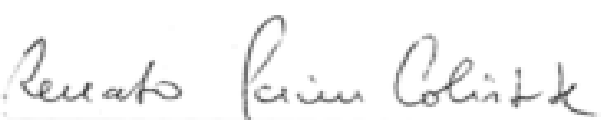

(Assinatura do (a) orientador (a) 
Fanus

Universidade de São Paulo

Faculdade de Filosofia, Letras e Ciências Humanas

\section{ATA DE DEFESA}

Aluno: 8137 - 5879389 - 1/ Página 1 de 1

Ata de defesa de Tese do(a) Senhor(a) André Luiz Lanza no Programa de História Econômica do(a) Faculdade de Filosofia. Letras e Ciências Humanas da Universidade de São Paulo.

Aos 30 dias do mês de abril de 2021, no(a) Sala virtual realizou-se a Defesa da Tese do(a) Senhor(a) André Luiz Lanza, apresentada para a obtenção do título de Doutor intitulada:

"De braços para a lavoura a proprietários rurais? Imigrantes e o acesso à terra em São Paulo, 1886-1920"

Após declarada aberta a sessão, o(a) Sr(a) Presidente passa a palavra ao candidato para exposição e a seguir aos examinadores para as devidas arguições que se desenvolvem nos termos regimentais. Em seguida, a Comissão Julgadora proclama o resultado:

$\begin{array}{llll}\text { Nome dos Participantes da Banca } & \text { Função } & \text { Sigla da CPG } & \text { Resultado } \\ \text { Renato Perim Colistete } & \text { Presidente } & \text { FEA - USP } & \text { Não Votante } \\ \text { Paulo Cesar Gonçalves } & \text { Titular } & \text { FCL-UNESP - Externo } & \text { Aprovado } \\ \text { Lelio Luiz de Oliveira } & \text { Titular } & \text { FEARP - USP } & \text { Aprovado } \\ \text { Bruno Gabriel Witzel de Souza } & \text { Suplente } & \text { GAUG - Externo } & \text { Aprovado }\end{array}$

Resultado Final: Aprovado

Eu, _. lavrei a presente ata , que assino juntamente com os(as) Senhores(as) examinadores. Săo Paulo, aos 30 dias do mês de abril de 2021

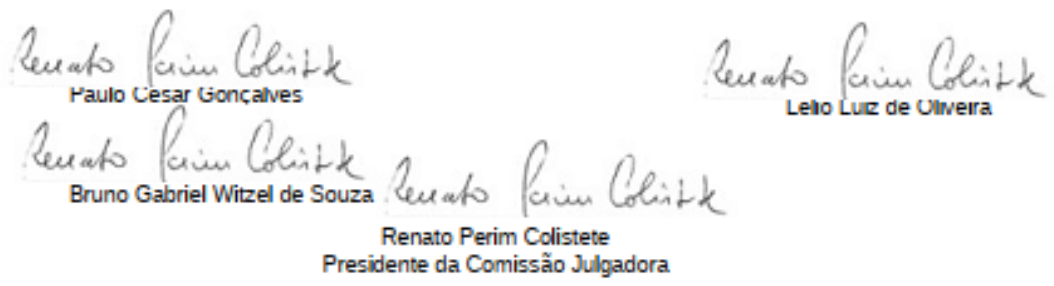

A defesa foi homologada pela Comissão de Pós-Graduação em 30104/2021 e, portanto, o(a) aluno(a) faz jus ao título de Doutor em Ciências obtido no Programa História Econômica.

Presidente da Comissão de Pós-Graduação 
A meus pais,

Carmen e Carlos 
Ao meu companheiro e melhor amigo,

Maurício 


\section{AGRADECIMENTOS}

Escrever esses agradecimentos não é uma tarefa fácil. Eu tive a sorte de ter em meu caminho pessoas incríveis que colaboraram para fazer desta uma etapa menos solitária e, incorrendo no risco de esquecer alguém, já deixo registrado aqui meu profundo muito obrigado a todos que me acompanharam nos últimos anos.

Primeiramente, gostaria de agradecer ao meu orientador, Prof. Dr. Renato Perim Colistete. Realizar essa jornada chamada doutorado sob sua orientação foi uma experiência única. Prof. Renato não é aquele orientador que te carrega pela mão. Ao invés, ele acompanhou atentamente todas as etapas, iluminou o caminho quando eu me senti perdido, ensinou-me a olhar as fontes e os dados imparcialmente e com devido rigor acadêmico. Sempre solícito e respeitoso, compartilhou comigo uma fração do seu enorme conhecimento em história econômica e ajudou a moldar minha forma de fazer pesquisa. Um simples "muito obrigado" não seria suficiente para expressar a gratidão pelos últimos cinco anos. Sem sua orientação, essa tese não seria a mesma.

Agradeço aos professores da minha banca de qualificação, Maria Lúcia Lamounier, minha eterna orientadora, e Lélio Luiz de Oliveira pelos comentários, críticas e observações que ajudaram a traçar o caminho que essa tese seguiu. Agradeço também ao Prof. Aldo Musacchio, por ter me escolhido para ser seu Research Assistant, pelos incentivos à pesquisa e pelos comentários nos meus textos.

Sou eternamente grato ao Lucas Cavalcanti, que mais que um colega de trabalho, se tornou um amigo. Obrigado pelas discussões, pelas trocas de ideias e pelas longas horas me ensinando programação e me ajudando a trazer à luz o que os dados escondiam. Nesse mesmo sentido, sou grato também ao Danilo Lessa, pelo auxílio e ajuda nos códigos que deram vida a esta tese. Aos colegas que estiveram presente nos workshops de História Econômica conduzidos pelo Prof. Renato, sou grato pelos debates e conhecimentos partilhados. Por fim, sou afortunado por ter tido a chance de conhecer o Bruno Witzel de Souza, um pesquisador exemplar, um ser humano sensacional e um grande amigo. Obrigado por, mesmo estando literalmente a meio mundo de distância, ter sempre tido um tempo para debater ideias, compartilhar seus conhecimentos comigo e me incluir nos seus projetos. 
Aos meus amigos de longa data, agradeço a vocês pela paciência que tiveram comigo, por compreenderem as ausências e por serem os tão necessários ombros para as lamúrias da minha vida acadêmica.

Ao meu melhor amigo e meu companheiro, Maurício dos Santos Pereira, não existem palavras para agradecer o apoio, o carinho e a compreensão que você teve comigo nessa dura jornada, especialmente nos últimos meses. Obrigado por acreditar em mim quando nem eu mesmo acreditava, por não me deixar desistir e por ter estado ao meu lado nos momentos mais difíceis e estressantes desse doutorado. Sua paciência, seu amor, seu respeito foram fundamentais para a conclusão deste trabalho.

Não poderia deixar de agradecer também aos funcionários do Arquivo Público do Estado de São Paulo pela atenção e solicitude durante as diversas visitas que realizei ao acervo ao longo dos últimos anos. Agradeço por terem fornecido a base de dados dos registros de matrícula da Hospedaria de Imigrantes, peça fundamental para a confecção desta tese.

Aos funcionários e professores do Programa de Pós-Graduação em História Econômica da Faculdade de Filosofia, Letras e Ciências Humanas (FFLCH/USP) e da Faculdade de Economia, Administração e Contabilidade da Universidade de São Paulo (FEA/USP), meu muito obrigado pela acolhida e pelos conhecimentos compartilhados.

Ao $\mathrm{CNPq}$, pela bolsa de doutorado que tornou possível a realização dessa pesquisa.

Por fim, agradeço aos meus pais, que nunca mediram esforços para me oferecer uma educação de qualidade e me apoiaram, financeira e emocionalmente, durante todas as etapas da minha pós-graduação. Vocês são os que mais torcem pelo meu sucesso. Vocês são minhas maiores fontes de inspiração. Essa tese é de vocês. 


\section{RESUMO}

O objetivo do presente trabalho é estudar a mobilidade econômica de imigrantes europeus via acesso à terra no estado de São Paulo no início do século XX. De 1886 a 1920, mais de 1,5 milhão de imigrantes europeus entraram no estado de São Paulo para trabalhar nas plantações de café ao lado de escravos e depois da abolição. Mais da metade desses imigrantes utilizou o programa de subsídios do governo provincial, posteriormente estadual, que previa passagens para cruzar o Atlântico, hospedagem na Hospedaria de Imigrantes na cidade de São Paulo após a chegada e contrato de trabalho em uma fazenda de café no interior. Os imigrantes eram normalmente pessoas pobres que, sem os subsídios, não teriam meios nem teriam escolhido São Paulo para migrar. O sonho de se tornarem proprietários de terras foi provavelmente o principal fator de atração para a maioria desses imigrantes. Apesar das leis fundiárias formuladas pelas elites agrárias e de uma política de imigração para atrair os europeus mais pobres para as fazendas, muitos estrangeiros realmente obtiveram terras, se assentaram e se integraram à sociedade brasileira e paulista. Inicialmente, esta tese reconstitui o processo de elaboração da legislação paulista de terras a partir dos debates na Assembleia Legislativa de São Paulo, jornais e em outras esferas para analisar as possibilidades e restrições enfrentadas pelos imigrantes no acesso à terra em São Paulo. Em seguida, utilizando dados de registros de matrícula de 1,5 milhão de imigrantes em trânsito pela Hospedaria de Imigrantes entre 1886 e 1920, analisou-se a distribuição dos estrangeiros pelos municípios e regiões de São Paulo entre os períodos de 1886 a 1900 e 1901 a 1920. Na sequência, foram utilizados dados individuais dos proprietários rurais listados na Estatística Agrícola e Zootécnica do Estado de São Paulo para o ano agrícola de 1904-5 e dados do censo agrícola para São Paulo do Recenseamento Geral de 1920 para traçar um panorama das propriedades rurais de estrangeiros e sua participação na agricultura paulista no início do século XX. Por fim, usando técnicas de análise de dados em Python, os nomes dos europeus listados como proprietários de terras na Estatística Agrícola de 1905 foram cruzados com os nomes dos imigrantes registrados na Hospedaria de Imigrantes entre 1886 e 1904. Esse cruzamento dos dados permitiu identificar quem eram e o número dos imigrantes da Hospedaria que conseguiram adquirir terras em São Paulo. O presente trabalho contribui não só para o estudo da imigração no Brasil e em São Paulo, ajudando a resolver um debate clássico na historiografia sobre se os imigrantes que foram trabalhar nas fazendas de café conseguiram ascender à condição de proprietários, mas também é útil para futuros trabalhos sobre integração e assimilação de estrangeiros em sociedades receptoras e estudos comparativos sobre o assunto.

Palavras-chaves: Imigração; Terras; Política fundiária; Mobilidade econômica; São Paulo. 


\begin{abstract}
The present work aims to study the social and economic mobility of European immigrants via access to land in the state of São Paulo at the beginning of the 20th century. From 1886 to 1920, more than 1.5 million European immigrants entered the state of São Paulo to work on coffee plantations side by side with slaves and on the post-abolition. More than half of them came to the state through the provincial, later state, government's subsidy program, which provided for transatlantic tickets, accommodation in the Immigrant's Hostel at São Paulo city (Hopedaria de Imigrantes) after arrival and a work contract at a coffee farm in the countryside. These immigrants were normally poor people who, without subsidies, would have neither the means nor would choose São Paulo to migrate. The dream of becoming landowners was probably the main attraction factors for most of these immigrants. Despite land laws designed to protect existing agrarian elites and an immigration policy to attract the poorest Europeans, many have actually obtained land, settled and integrated themselves into Brazilian and São Paulo society. Initially, this thesis reconstructed the process of drafting São Paulo land legislation based on debates in the São Paulo Legislative Assembly and in São Paulo society to analyze the possibilities and restrictions faced by immigrants in accessing land in São Paulo. Then, using registration data from 1.5 million immigrants passed by the Immigrants' Hostel between 1886 and 1920, the distribution of foreigners by the municipalities and regions of São Paulo between the periods from 1886 to 1900 and 1901 to 1920 was analyzed. In the sequence, individual data on rural landowners listed at the Agricultural and Zootechnical Statistics of the State of São Paulo for the 1904-5 agricultural year and aggregated data from the agricultural census for São Paulo from the 1920 General Census were used to provide an overview of foreigners' rural properties and their participation in São Paulo agriculture in the early 20th century. Finally, using data analysis techniques in Python, the names of Europeans listed as landowners in the 1905 Agricultural Statistics were crossed with the names of immigrants registered at the Immigrants' Hostel between 1886 and 1904. This data crossing allowed me to identify who were and how many of the immigrants from the Hostel managed to acquire land in São Paulo. The present work contributes not only to the study of immigration in Brazil and São Paulo, helping to resolve a classic historiographical debate about whether immigrants who came to work on coffee farms managed to rise to the status of landowners, but it is also useful for future work on integration and assimilation of foreigners in receiving societies and comparative studies on the subject.
\end{abstract}

Key-words: Immigration; Land; Land legislation; Economic mobility; São Paulo. 


\section{LISTA DE ABREVIAÇÕES}

AALPSP - Anais da Assembleia Legislativa Provincial de São Paulo AESP - Arquivo do Estado de São Paulo

ALESP - Assembleia Legislativa do Estado de São Paulo

ASI - Anais do Senado do Império do Brasil

SPI - Sociedade Promotora de Imigração

SCI - Sociedade Central de Imigração

SISP - Sociedade de Imigração de São Paulo 


\section{LISTA DE IMAGENS}

Imagem 2.1 - Registro de matrícula de imigrantes, Livro 60, p. 1 ...................................... 72 


\section{LISTA DE FIGURAS}

Figura 2.1 - Divisão do estado de São Paulo em regiões, 1905 ...................................................64

Figura 2.2 - Divisão do estado de São Paulo em regiões, 1920 ................................................65

Figura 3.1 - Propriedades rurais de estrangeiros em São Paulo, 1905, em termos relativos .... 101

Figura 3.2 - Propriedades rurais de estrangeiros em São Paulo, 1920, em termos relativos .... 102

Figura 3.3 - Porcentagem da área total em cultivo por nacionais e estrangeiros, por região, 1905

Figura 3.4 - Participação de cada gênero na área cultivada nas propriedades de estrangeiros em São Paulo, 1905

Figura 4.1 - Heatmap de localização inicial e localização das propriedades de imigrantes, por zona, 1905 136 


\section{LISTA DE TABELAS}

Tabela 1.1 - Núcleos coloniais fundados em São Paulo entre 1905 e 1911

Tabela 2.1 - Destino dos imigrantes saídos da Hospedaria, por região do estado de São Paulo, 1886-1900

Tabela 2.2 - Dez municípios que mais receberam imigrantes saídos da Hospedaria, São Paulo, 1886-1900

Tabela 2.3 - Destino dos imigrantes saídos da Hospedaria, por região do estado de São Paulo, $1901-1920$

Tabela 3.1 - Regiões, municípios e propriedades rurais, estado de São Paulo, 1905 e 1920......94

Tabela 3.2 - Áreas total e média das propriedades rurais por regiões do estado de São Paulo, em 1905 e 1920 , em alqueires

Tabela 3.3 - Área cultivada das propriedades rurais do estado de São Paulo, em 1905 e 1920, em alqueires e em porcentagem

Tabela 3.4 - Nacionalidades dos proprietários rurais nas regiões do estado de São Paulo, 1905, absoluto e em porcentagem ....

Tabela 3.5 - Propriedades rurais por nacionalidade em cada região do estado de São Paulo, 1905, em porcentagem .

Tabela 3.6 - Proprietários rurais no estado de São Paulo de acordo com a nacionalidade, por região, em termos absolutos e relativos, em 1905 e 1920 103

Tabela 3.7 - Análise de correlação entre produção agrícola e as propriedades de imigrantes para 1905

Tabela 3.8 - Análise de correlação de Spearman entre produção agrícola e dispersão das

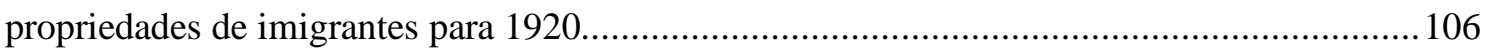

Tabela 3.9 - Concentração relativa de propriedades por nacionalidade, São Paulo, 1905 ........108

Tabela 3.10 - Concentração relativa de propriedades por nacionalidade, São Paulo, 1920......110

Tabela 3.11 - Propriedades rurais pertencentes a estrangeiros por tamanho em São Paulo, 190405 , valores absoluto e relativo

Tabela 3.12 - Áreas total e cultivada das propriedades de estrangeiros por tamanho em São Paulo, 1904-05, em porcentagem

Tabela 3.13 - Índice de Gini da área total para as propriedades rurais de imigrantes em São Paulo, 1905

Tabela 3.14 - Área ocupada das propriedades rurais no estado de São Paulo em 1920, por região e nacionalidade, em alqueires

Tabela 3.15 - Área cultivada de cada produto nas propriedades de estrangeiros, por região, 1905, em porcentagem

Tabela 3.16 - Participação da produção dos produtos cultivado nas propriedades de estrangeiros na produção total cultivada do produto, por região, 1905, em porcentagem.

Tabela 4.1 - Amostra resultante do processo de matching, por nacionalidade (Estado de São Paulo, 1905).

Tabela 4.2 - Tamanho e localização das propriedades mapeadas dos italianos no estado de São Paulo, por região, 1905 138 
Tabela 4.3 - Tamanho e localização das propriedades mapeadas dos espanhóis no estado de São Paulo, por região, 1905 


\section{SUMÁRIO}

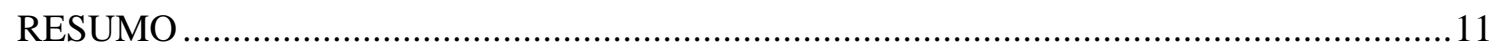

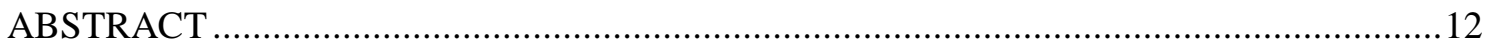

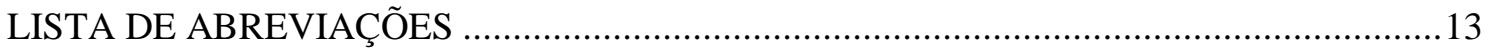

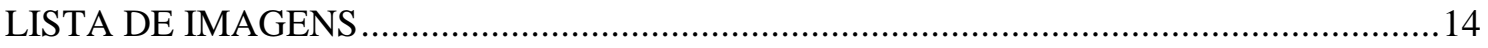

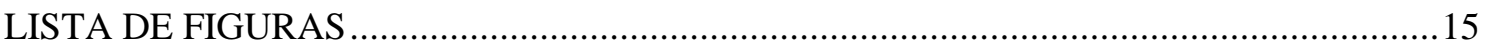

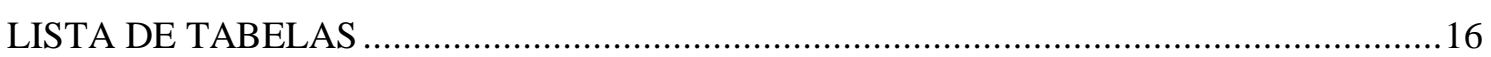

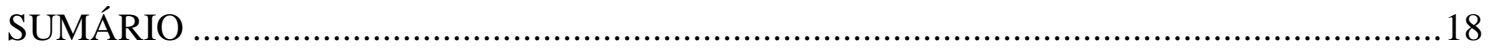

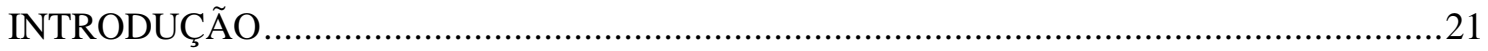

CAPÍTULO 1 - TERRAS E IMIGRAÇÃO EM SÃO PAULO................................................26

1.1. Primeiras políticas de terras e imigração na província de São Paulo ............................27

1.1.1. A Sociedade de Imigração de São Paulo ......................................................... 32

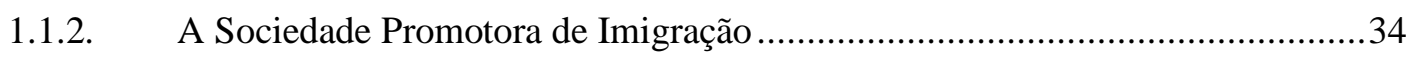

1.2. A legislação fundiária do estado de São Paulo .............................................................39

1.3. Os núcleos coloniais em São Paulo durante a Primeira República ...............................47

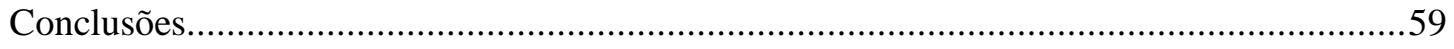

CAPÍTULO 2 - OS REGISTROS DE MATRÍCULA DA HOSPEDARIA DE IMIGRANTES

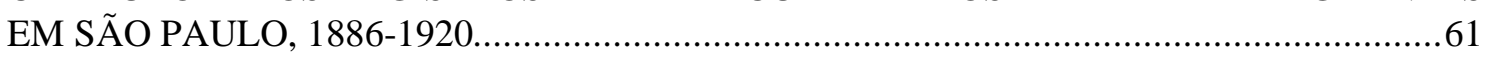

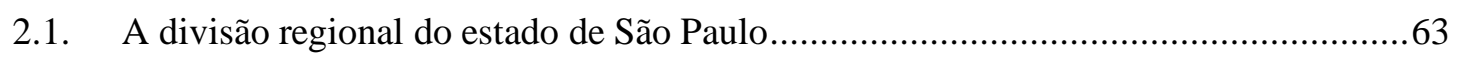

2.2. A Hospedaria de Imigrantes e os registros de matrícula ...............................................66

2.3. A imigração segundo os registros de matrícula da Hospedaria de Imigrantes .............73

2.3.1. A distribuição geográfica dos imigrantes em São Paulo ...................................75

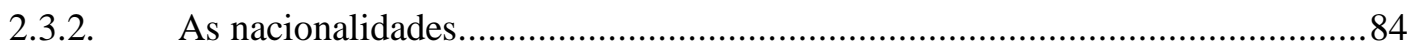

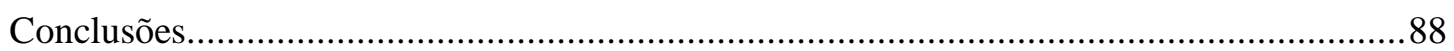

CAPÍTULO 3 - AS PROPRIEDADES DOS ESTRANGEIROS EM SÃO PAULO, 1905-1920

3.1. A agricultura paulista no começo do século XX: um breve panorama .......................91

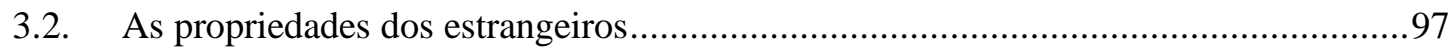

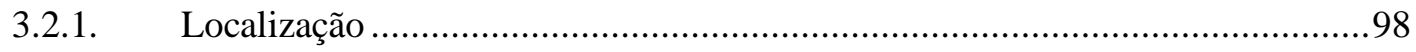

3.2.2. Participação relativa das propriedades de imigrantes no estado ...................... 107

3.2.3. Tamanho das propriedades dos estrangeiros............................................... 110

3.2.4. Produção das propriedades dos imigrantes .................................................... 119

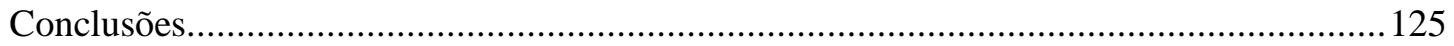

CAPÍTULO 4 - OS IMIGRANTES PROPRIETÁRIOS RURAIS EM SÃO PAULO NO

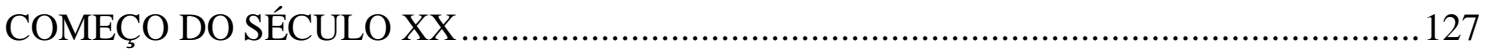

4.1. Identificando os imigrantes proprietários ............................................................. 128

4.1.1. Realizando o matching entre as bases de dados .......................................... 129

4.2. Resultados da correspondência entre as bases de dados........................................... 132 


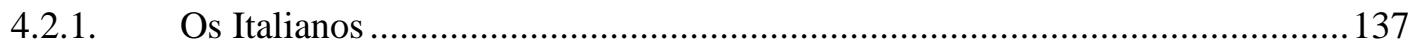

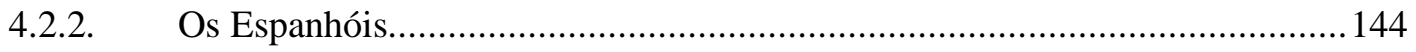

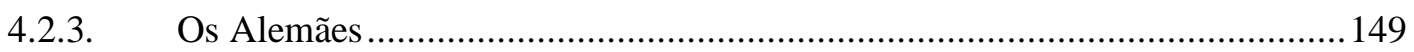

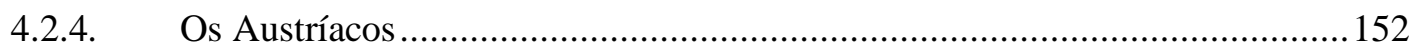

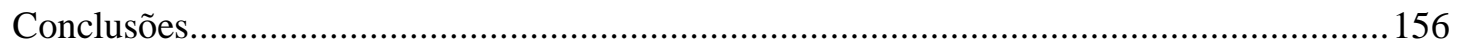

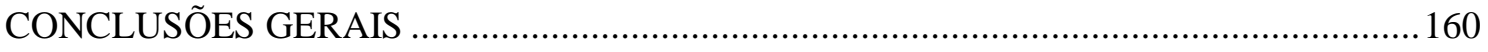

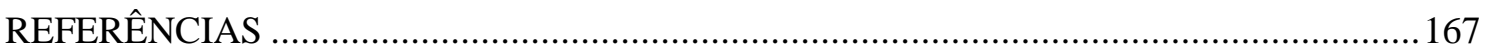

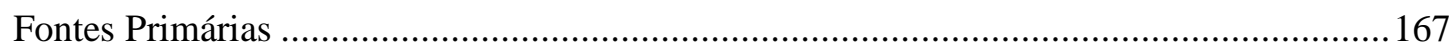

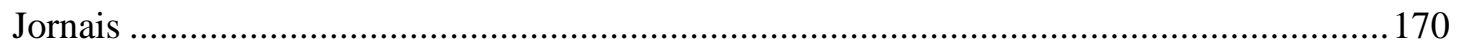

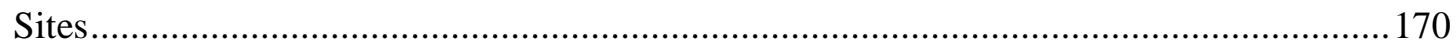

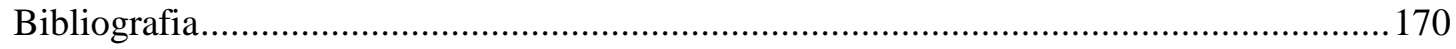

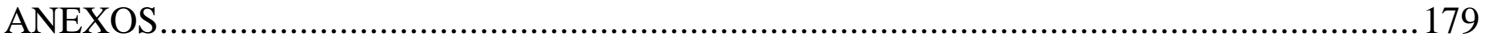


No entretanto, o ovo, e apesar

Da pura forma concluída,

Não se situa no final:

Está no ponto de partida"

- João Cabral de Melo Neto, Obras Completas 


\section{INTRODUÇÃO}

Entre a década de 1880 e 1920, mais de 38 milhões de pessoas deixaram a Europa e cruzaram o Atlântico em busca de uma vida melhor no então chamado Novo Mundo. ${ }^{1}$ O Brasil recebeu, no mesmo período, quase 3,5 milhões desses imigrantes. Para São Paulo, aproximadamente 60\% dos imigrantes foram atraídos pelos subsídios pagos pelo governo, pelas oportunidades de trabalho nas fazendas e pelo anseio de tornarem-se proprietários de terra. ${ }^{2}$ Os imigrantes integraram-se e tornaram-se parte da população paulista. Se em 1872, data do primeiro censo nacional, São Paulo possuía uma população de 837.352 indivíduos, dos quais 3,5\% eram estrangeiros, em 1920 habitavam o estado 4,6 milhões de pessoas, sendo $19 \%$ nascidos fora do país. ${ }^{3}$

A expansão da agricultura de exportação, ao mesmo tempo em que o fim da escravidão se aproximava, levou a elite cafeicultora a intensificar a busca por outras fontes de trabalho para as fazendas. ${ }^{4}$ Após diversas experiências fracassadas com o trabalho livre, os fazendeiros e o governo paulista criaram, em 1884, um programa de imigração subsidiado para atrair famílias europeias pobres que buscavam oportunidades de trabalho do outro lado do Atlântico. Muito se tem escrito sobre a presença desses estrangeiros no estado de São Paulo, especialmente no contexto da chamada transição da mão de obra escrava para a livre e seu papel na agricultura. ${ }^{5}$ No entanto, existem

\footnotetext{
${ }^{1}$ Mario Rapoport, Historia económica, política y social de la Argentina, 1880-2000 (Buenos Aires: Editorial Macchi, 2000), 43. Stanley L. Engerman e Kenneth L. Sokoloff, "Once Upon a Time in the Americas: Land and Immigration Policies in the New World," in Understanding Long-Run Economic Growth: Geography, Institutions, and the Knowledge Economy, ed. Dora L. Costa e Naomi R. Lamoreaux (University of Chicago Press, 2008).

${ }^{2}$ Maria Stella Ferreira Levy, "O papel da migração internacional na evolução da população brasileira (1872-1972)," Revista de Saúde Pública 8 (1974): 71-2.

${ }^{3}$ São Paulo, Departamento Estadual de Estatística, Anuário Estatístico do Estado de São Paulo. v. 1 Estatísticas físicas, demográficas, sociais e culturais. Ano de 1944 (São Paulo: Industria Gráfica Siqueira S/A, 1948), 91-2.

${ }^{4}$ Sergio Milliet, "Roteiros do café," in: Roteiros do café e outros ensaios, ed. Sergio Milliet (São Paulo: Coleção Departamento de cultura, 1941); Thomas Holloway, Imigrantes para o café: Café e sociedade em São Paulo, 1886-1934 (Rio de Janeiro. Paz e Terra, 1984), 261-2.

${ }^{5}$ Michael Hall, "Origins of mass migration in Brazil, 1871-1914" (PhD Thesis, Columbia University, 1969); Holloway, Imigrantes, 212-3; Warren Dean, "A pequena propriedade dentro do complexo cafeeiro: Sitiantes no município de Rio Claro, 1870-1920," Revista de História 53, n. 106 (1976); Maria Thereza Schorer Petrone, Imigrantes e a pequena propriedade (São Paulo: Brasiliense, 1982), 45-50; Maria Lucia Lamounier, "Between slavery and free labour: experiments with free labour and patterns of slave emancipation in Brazil and Cuba c.1830-1888" (PhD diss., The London School of Economics and Political Science, 1993); Herbert Klein, "European and Asian Migration to Brazil," in The Cambridge Survey of World Migration, ed. Robin Cohen (Cambridge: Cambridge University Press, 2005); Bruno Gabriel Witzel de Souza, "From Bonded Laborers to Educated Citizens? Immigration, Labor Markets, and Human Capital in São Paulo, Brazil (1820-2010)" (PhD diss., Georg-August-Universität Göttingen, 2019).
} 
diversos aspectos da presença desses imigrantes que são ainda pouco explorados. Esta tese tem como objetivo principal estudar um tema sobre o qual há muitas interrogações e pouco consenso na literatura: o acesso à terra pelos imigrantes e sua transformação em proprietários no estado de São Paulo.

Vários autores têm analisado o impacto da imigração europeia e a assimilação desses imigrantes nos Estados Unidos e Argentina, principais destinos de imigrantes nas Américas entre 1870 e 1930. Relativamente menos trabalhos têm sido dedicados ao caso do Brasil - o terceiro maior país receptor de europeus antes de 1930 no hemisfério ocidental. ${ }^{6}$ Alguns desses trabalhos buscaram traçar a trajetória dos imigrantes na economia cafeeira paulista, à semelhança do que é realizado nesta tese. Apenas a título de ilustração, Herbert Klein investigou comparativamente a integração de imigrantes italianos no Brasil, Argentina e Estados Unidos. ${ }^{7}$ Como exemplos de estudos locais, Marília Cánovas mostrou, por meio de entrevistas individuais com imigrantes espanhóis e seus descendentes, a trajetória dos imigrantes que passaram de colonos a proprietários de terra e empresários urbanos em uma cidade exportadora de café do estado de São Paulo. ${ }^{8}$ Já Fernando Abrahão, utilizando inventários post-mortem, analisou a composição da riqueza de imigrantes no município de Campinas no fim do século XIX e começo do século XX. ${ }^{9}$

Diferentemente dos trabalhos acima mencionados, apresenta-se aqui um estudo da história dos imigrantes contada pelo ângulo do acesso à terra em São Paulo. A história dos imigrantes como proprietários rurais, sua participação na agricultura

\footnotetext{
${ }^{6}$ Sobre a mobilidade socioeconômica de imigrantes nos Estados Unidos, ver: Barry Chiswick e Timothy Hatton, "International Migration and the Integration of Labor Markets," IZA Discussion Papers n. 559 (2002); Ran Abramitzky, Leah Platt Boustan e Katherine Eriksson, "Europe's Tired, Poor, Huddled Masses: Self-Selection and Economic Outcomes in the Age of Mass Migration," American Economic Review 102 (2012); Ran Abramitzky, Leah Platt Boustan e Katherine Eriksson, "Have the poor always been less likely to migrate? Evidence from inheritance practices during the Age of Mass Migration," Journal of Development Economics 102 (2013); Ran Abramitzky, Leah Platt Boustan e Katherine Eriksson, "A Nation of Immigrants: Assimilation and Economic Outcomes in the Age of Mass Migration," Journal of Political Economy 122, n. 3 (June/2014). Sobre a Argentina, ver: María Liliana da Orden, Inmigración Española, Familia Y Movilidad Social En La Argentina Moderna: Una Mirada Desde Mar Del Plata (1890-1930) (Buenos Aires: Biblos, 2005); Santiago Pérez, "Intergenerational Occupational Mobility across Three Continents," The Journal of Economic History 79 (Jun. 2019); Santiago Pérez, "The (South) American Dream: Mobility and Economic Outcomes of First-and SecondGeneration Immigrants in Nineteenth-Century Argentina," The Journal of Economic History 77 (2017).

${ }^{7}$ Herbert Klein, "A Integração dos Imigrantes Italianos no Brasil, na Argentina e Estados Unidos," Revista Novos Estudos 25 (out./1989).

${ }^{8}$ Marília D. K. Cánovas, "A emigração espanhola e a trajetória do imigrante na cafeicultura paulista: o caso de Villa Novaes, 1880-1930" (Dissertação de Mestrado, FFLCH/USP, 2001).

${ }^{9}$ Fernando Antônio Abrahão, "Padrões de riqueza e mobilidade social na economia cafeeira: Campinas, 1870-1940" (Dissertação de Doutorado, FFLCH-USP, 2015).
} 
paulista no início do século XX e as condições de acesso à terra trazem várias questões que ainda permanecem pouco conhecidas. ${ }^{10} \mathrm{O}$ período estudado vai de 1886 , quando há um aumento exponencial das entradas de imigrantes subsidiados no estado, até 1920, quando o primeiro ciclo da imigração europeia já estava claramente delineado. Os capítulos a seguir, portanto, trazem novas informações para entender quem foram os imigrantes que chegaram em São Paulo durante a grande imigração e sob quais condições parte desses imigrantes foi capaz de tornar-se proprietária rural até as primeiras décadas de século XX.

Para se compreender as condições, as dificuldades e os eventuais sucessos dos imigrantes enquanto proprietários de terra é preciso, inicialmente, analisar como a legislação fundiária e a política imigratória de São Paulo trataram a questão do acesso à terra em geral, tanto para brasileiros como para estrangeiros. Dentro do contexto de uma sociedade de base agrícola, dominada pelos interesses dos grandes proprietários, é necessário analisar como essas políticas podem ter contribuído ou limitado as oportunidades para que os imigrantes adquirissem propriedades rurais. No Capítulo 1 são reconstituídos os debates travados na Assembleia Legislativa de São Paulo e nos jornais da época que influenciaram as políticas de terras e imigração implementadas em São Paulo. O material utilizado compreende os Anais da Assembleia Legislativa de São Paulo, os jornais da época, os boletins e as atas das sociedades imigratórias. No capítulo, examinam-se as diversas propostas legislativas e ideias sobre o assentamento de imigrantes em pequenas propriedades, os obstáculos impostos pelos grandes proprietários e o papel que as sociedades de imigração tiveram na defesa do acesso à terra pelos imigrantes e na promoção da imigração para São Paulo.

Ao longo da década de 1880, as leis promulgadas pelo governo de São Paulo e a criação da Sociedade Promotora de Imigração deram forma a um programa de introdução de europeus, organizando um amplo sistema de subsídios que contribuiu decisivamente para a chamada imigração em massa. De 1884, quando teve início o programa de subsídios, até 1920, quase 1,8 milhão de imigrantes entraram em São Paulo, em sua grande maioria para o trabalho nas fazendas do interior da

\footnotetext{
${ }^{10}$ Dentre a literatura clássica sobre imigração e terras, ver: Paula Beiguelman "A grande imigração em São Paulo II," Revista do Instituto de Estudos Brasileiros, n. 4 (jul. 1968): 155-7; Hall, "Origins," 180-3; Warren Dean, Rio Claro: um sistema brasileiro de grande lavoura (1820-1920) (Rio de Janeiro: Editora Paz e Terra, 1977), 177-82; Dean, “A pequena”; Petrone, Imigrantes; Holloway, Imigrantes; Mauricio Font, "Changing patterns in the Social Organization of the Coffee Export Sector in São Paulo, 18891930," Center for Research on Social Organization, University of Michigan Working Paper 268 (1982).
} 
província/estado. Mais da metade desse contingente foi atraída pelos auxílios do governo.

Todos os imigrantes subsidiados obrigatoriamente deveriam passar pela Hospedaria de Imigrantes em São Paulo, onde eram matriculados, alojados, firmavam um contrato de trabalho e eram transportados até o destino final nas fazendas de café. Os registros de matrícula da Hospedaria de Imigrantes constituem uma fonte rica e quase inexplorada sobre a imigração, sobre o perfil dos imigrantes e sua distribuição em São Paulo. O Capítulo 2 é dedicado à análise dessa base de dados. Existem lacunas nas estatísticas imigratórias para o início do programa de imigração subsidiada, entre 1886 e 1900, especialmente no tocante à distribuição dos imigrantes da Hospedaria em São Paulo. As estatísticas oficiais do governo do estado trazem o destino tomado por esses imigrantes a partir de 1896. Após a limpeza, organização e sistematização desses dados, foram criadas séries de imigração por nacionalidade, destino e ano para dois períodos, de 1886 a 1900 e de 1901 a 1920, que formam a base da análise realizada no Capítulo 2. Optou-se por dividir o período em duas partes para devido à mencionada lacuna estatística entre 1886 e 1900. Dessa forma, será possível melhor apresentar e analisar detalhadamente o fluxo de imigrante da Hospedaria para os municípios paulistas. Além dos fluxos e destinos, outras características dos imigrantes da Hospedaria são estudadas, como a composição familiar, a proporção de homens e mulheres, ocupação e a modalidade de imigração - se espontânea ou subsidiada.

O Capítulo 3 apresenta um estudo sistemático das propriedades rurais pertencentes a estrangeiros em São Paulo no começo do século XX. Para tanto, foram utilizadas a Estatística Agrícola-Zootécnica do Estado de São Paulo do ano agrícola de 1904-05 e o Recenseamento Agrícola para o estado de São Paulo do Censo do Brasil de 1920. Há trabalhos importantes que abordaram a presença dos imigrantes como proprietários de terra em São Paulo. ${ }^{11}$ Conforme a Estatística Agrícola de 1905, 15\% dos estabelecimentos rurais de São Paulo estavam em mãos de proprietários estrangeiros. Em 1920, os estrangeiros eram donos de quase $28 \%$ das propriedades rurais do estado. No Capítulo 3, busca-se estudar quais eram as principais nacionalidades entre os estrangeiros proprietários, onde estavam concentradas as propriedades dos estrangeiros em São Paulo, qual o tamanho dessas propriedades, a

\footnotetext{
${ }^{11}$ Holloway, Imigrantes, cap. 6; José Francisco Camargo, Crescimento da população do Estado de São Paulo e seus aspectos econômicos (São Paulo: Instituto de Pesquisas Econômicas, 1981), 247-54.
} 
combinação de culturas agrícolas nelas adotada e o peso dessas propriedades e das culturas nelas cultivadas na agricultura paulista no começo do século XX.

Apesar da reconhecida presença dos estrangeiros como proprietários rurais em São Paulo, não existe consenso na historiografia sobre quem foram esses imigrantes e como conseguiram acesso à terra no estado. O Capítulo 4 combina dados individuais da Estatística Agrícola de 1905 com os registros de matrícula da Hospedaria de Imigrantes de 1884 a 1904 para mapear a trajetória dos estrangeiros que se tornaram proprietários de terra no estado de São Paulo. A política de imigração subsidiada empreendida pelo governo paulista privilegiou, em um primeiro momento, a atração de famílias de europeus pobres dedicadas ao trabalho nas fazendas de café. Ao cruzar os registros de matrícula com os nomes dos proprietários rurais estrangeiros, foi possível verificar se esses imigrantes mais pobres, chegados com subsídios, tiveram a chance de "fazer a América" e tornar-se agricultores independentes.

Ao final, as conclusões gerais fazem um balanço dos principais achados da tese e sugerem futuros caminhos da pesquisa sobre os temas aqui tratados. 


\section{CAPÍTULO 1 - TERRAS E IMIGRAÇÃO EM SÃO PAULO}

Durante o século XIX e começo do século XX, milhões de pessoas deixaram suas terras natais na Europa em busca de melhores condições de vida nos países do Novo Mundo. Entre 1820 e 1930, o Brasil recebeu quase 4,5 milhões de estrangeiros, sendo que só a província e o estado de São Paulo recebeu mais de $60 \%$ imigrantes. ${ }^{1}$ A história da imigração em São Paulo está intimamente ligada com a ascensão da economia cafeeira, a expansão da fronteira agrícola e os projetos de substituição do braço escravo nas fazendas diante da perspectiva da abolição da escravidão. A questão fundiária também foi um aspecto central nas políticas imigratórias do período. O anseio de tornar-se proprietário de terras era um dos motores da imigração europeia e essa motivação foi manipulada em todo o período pelos legisladores e governantes paulistas através de propaganda e promessas para atrair imigrantes e formar uma espécie de proletariado rural estrangeiro necessário às fazendas cafeeiras. ${ }^{2}$

Ainda que a historiografia trate do acesso à terra pelos imigrantes em São Paulo, a maioria dos trabalhos tem abordado o tema de forma implícita, sobretudo ao discutirem questões correlatas, como a imigração e suas motivações. ${ }^{3}$ Poucos autores discutem esse tema, por exemplo, sob a ótica do pensamento vigente entre as elites e no parlamento paulista. ${ }^{4}$ Em uma sociedade agroexportadora, onde predominavam as grandes propriedades, era de se esperar que a legislação e as políticas fundiárias visassem preservar o status quo e limitar o acesso dos estrangeiros à propriedade rural e a proliferação da pequena propriedade. Ao mesmo tempo, o interesse predominante era a atração de mão de obra estrangeira para o trabalho na fazenda e não para o povoamento. Apesar disso, os debates políticos e o pensamento dos ideólogos da imigração para São Paulo mostram que houve, se não uma defesa propriamente da promoção da imigração para a pequena propriedade, pelo menos surgiram projetos que vislumbravam essa possibilidade. É em tal contexto que esse capítulo avalia os debates travados na Assembleia Legislativa de São Paulo, nos jornais da época e nos discursos dos governantes e da elite cafeeira que influenciaram as políticas de terras e imigração

\footnotetext{
${ }^{1}$ Levy, "O papel"

2 Dean, Rio Claro, 122-3; Holloway, Imigrantes, 212-3; Maria Thereza Schorer Petrone, "Imigração," in O Brasil republicano. Sociedade e instituições (1889-1930), org. Boris Fausto (Rio de Janeiro: Bertrand Brasil, 1997), 128; Chiara Vangelista, Os braços da lavoura (São Paulo: Hucitec, 1991).

${ }^{3}$ Holloway, Imigrantes, 210-48; Camargo, Crescimento, 247-54; Petrone, Imigrantes.

${ }^{4}$ Holloway, Imigrantes, 170-209.
} 
implementadas em São Paulo, enfatizando como foi encarado o acesso à terra pelos imigrantes.

Este capítulo está dividido em três partes. Na primeira seção, são abordadas as primeiras políticas de imigração e colonização empregadas na província de São Paulo ao longo do século XIX. Em seguida, são estudados os debates, as ideias e as propostas de legisladores e políticos paulistas que culminaram nas legislações fundiárias adotadas em São Paulo após a Proclamação da República, quando os estados passaram a decidir livremente sobre as terras devolutas contidas em seus limites. Será destaca em particular a maneira com que foi tratada a questão do acesso à terra pelos imigrantes. Por fim, dedica-se uma seção à política de núcleos coloniais adotada ao longo da Primeira República no estado de São Paulo. As principais fontes incluem os Anais da Câmara e do Senado Imperais, Assembleia Legislativa de São Paulo, os jornais da época e os boletins e atas das sociedades imigratórias, que serão utilizadas para reconstruir os debates e as visões dos parlamentares e membros da sociedade paulista com relação à apropriação territorial, à imigração e à pequena propriedade.

\subsection{Primeiras políticas de terras e imigração na província de São Paulo}

A história fundiária de São Paulo relaciona-se diretamente aos interesses da elite rural. As primeiras medidas visando introduzir imigrantes como pequenos proprietários remontam às primeiras tentativas de fundar colônias governamentais com imigrantes açorianos na região de Casa Branca. ${ }^{5}$ Essas proposições ganharam maior ênfase na década de 1820. Em 1827, foi estabelecida uma colônia de imigrantes alemães em Rio Negro - hoje no Paraná. ${ }^{6}$

Esses projetos de colonização se depararam com opiniões contrárias no governo paulista, em especial dos grandes fazendeiros, críticos da doação de terras de boa qualidade a estrangeiros. Nicolau Vergueiro, em parecer sobre o tema em 1830, afirmou que as localidades escolhidas pelo governo para estabelecer colônias não convinham aos imigrantes e não atendiam aos interesses dos proprietários. Essas colônias eram, segundo Vergueiro, distantes das estradas e dos centros urbanos, em sertão ainda por ser

\footnotetext{
5 Sobre os primórdios da colonização em São Paulo, ver: Sérgio Buarque de Holanda, "Prefácio do Tradutor," in Memórias de um colono no Brasil, Thomas Davatz (São Paulo: Livraria Martins, 1941), 5; Emília Viotti da Costa, Da monarquia à república: momentos decisivos (São Paulo: Fundação Editora da UNESP, 1999), 109-68.

6 Petroni, "Imigração," 96-7; Viotti da Costa, Da monarquia, 195-6.
} 
desbravado. Além disso, os altos custos envolvidos com a colonização e a necessidade de braços para a fazenda não justificariam os dispêndios com núcleos coloniais. ${ }^{7}$

Em trabalho recente, Bruno Witzel de Souza mostra que em 1835 houve uma iniciativa público-privada envolvendo fazendeiros, membros da elite política paulista e o governo provincial, conduzida pela firma Luiz Vergueiro \& Cia., para contratar 240 imigrantes suíços e alemães para as fazendas da província. ${ }^{8} \mathrm{O}$ contrato proposto no esquema previa o adiantamento da passagem dos imigrantes, com a contrapartida dos estrangeiros aceitarem trabalhar para o fazendeiro por um período de três anos. Após esse período, o imigrante teria a possibilidade de tornar-se proprietário, recebendo do governo de São Paulo um lote de terra que deveria cultivar por no mínimo seis anos antes de receber os direitos de propriedade. Complementarmente, os imigrantes também teriam seus direitos civis e religiosos garantidos. ${ }^{9}$ Esse parece ser um contrato inédito na época, sendo talvez o primeiro a propor ao imigrante o acesso à propriedade de terra ao fim do seu período de trabalho. ${ }^{10}$

O momento em que surgiu a proposta da Luiz Vergueiro e Cia., logo após a lei que aboliu oficialmente o tráfico de escravos pela primeira vez em 1831, retrata o temor e a mobilização dos fazendeiros e os governos paulista e central diante das ameaças do fim da escravidão. O período regencial acabou minando os já fracos esforços iniciais para atrair mão de obra imigrante. $\mathrm{O}$ contrato proposto por Vergueiro também não foi capaz de concretizar nenhuma onda imigratória efetiva. ${ }^{11}$

Em face das constantes pressões da Inglaterra pelo fim do tráfico, em especial em 1845 com a Lei Aberdeen, pareceu urgente a busca de outras fontes de trabalho para as fazendas. Em 1845, o governo central autorizou um crédito de 200 contos de réis, a ser obtido por meio da emissão de apólices, para estimular o recrutamento de imigrantes

\footnotetext{
7 Djalma Forjaz, O Senador Vergueiro: sua vida e sua época, 1778-1859 (São Paulo: Diario Official, 1924), 34-6.

${ }^{8}$ Witzel de Souza, "From bonded," 99-103.

${ }^{9}$ Direitos civis e liberdade de religião foram debatidos e resolvidos apenas no final do século XIX, com os escritos, por exemplo, de Tavares Bastos e as defesas e campanhas feitas pela Sociedade Central de Imigração no Rio de Janeiro. Aureliano C. Tavares Bastos, Os Males do Presente e as Esperanças do Futuro (São Paulo: Cia Editora Nacional, 1939), 110-8; A Immigração 21, jul. 1886.

${ }^{10}$ Luiz Mateus da Silva Ferreira mostrou em estudo recente a existência de um contrato de parceria em uma colônia oficial, a Dona Francisca em Santa Catarina, na década de 1850, que previa a alienação de 4,8 alqueires de terra aos colonos após o cumprimento do contrato. Luiz Mateus da Silva Ferreira, "Terra, Trabalho e Indústria na Colônia de Imigrantes Dona Francisca (Joinville), Santa Catarina, 1850-1920" (Tese de Doutorado, FFLCH/USP, 2019), 183-6.

${ }^{11}$ Witzel de Souza, "From bonded," 100.
} 
do norte da Europa. ${ }^{12}$ Em 1846, o governo de São Paulo decretou que o saldo das contas provinciais existente, após executadas as despesas para o ano financeiro, deveria ser utilizado para a compra de tais apólices do governo central. Com os juros dessas apólices, o governo pretendia contratar o transporte dos estrangeiros com empreendedores individuais e companhias nacionais e estrangeiras. Os imigrantes teriam de reembolsar o fazendeiro com seu trabalho. Ainda em 1846, o governo provincial concedeu auxílio para o estabelecimento de imigrantes alemães e belgas em colônias agrícolas a serem fundadas pela companhia ou indivíduo que importasse os colonos. $^{13}$

Foi neste contexto que o senador Vergueiro implementou as primeiras experiências com o trabalho livre imigrante em fazendas da província de São Paulo. Finalmente pondo em prática as ideias esboçadas quinze anos antes, Vergueiro contratou, em 1840, 80 imigrantes portugueses para trabalhar nos cafezais da fazenda Ibicaba, de sua propriedade, em Limeira. Entretanto, a experiência fracassou já em 1842, com a maioria dos imigrantes abandonando a fazenda. Alguns anos depois, em 1847, a firma Vergueiro \& Cia, do senador e dois de seus filhos, engajou 423 imigrantes alemães em um novo experimento que ficou conhecido como Colônia Senador Vergueiro, localizada novamente na fazenda Ibicaba. ${ }^{14}$ Esses imigrantes foram contratados sob o sistema de parceria, no qual o fazendeiro financiava o transporte do imigrante até o porto de Santos, os custos com o transporte até a fazenda e os gastos com mantimentos e ferramentas necessários para as famílias. Sobre tais adiantamentos incidiam juros de $6 \%$ ao ano. Os imigrantes deveriam reembolsar os gastos dos fazendeiros com ao menos metade dos seus lucros líquidos anuais derivados do café e ficavam impedidos de deixar a fazenda até que a dívida estivesse totalmente quitada. Os imigrantes tornavam-se ainda responsáveis por certo número de pés de café para cuidar, colher e beneficiar a produção, sendo também a eles atribuído um pedaço de terra para cultivo de gêneros alimentícios. A remuneração final consistia na divisão entre o fazendeiro e o imigrante dos lucros obtidos da venda do café. Ao imigrante cabia

\footnotetext{
${ }^{12}$ Lei n. 369 de 18 de setembro de 1845, art. 47.

${ }^{13}$ Lei n. 11 de 19 de fevereiro de 1846; Lei n. 37 de 16 de março de 1846.

${ }^{14}$ Uma análise detalhada dos empreendimentos do Senador Vergueiro na Ibicaba e de suas ramificações na agricultura paulista pode ser encontrada nos trabalhos clássicos de Sérgio Buarque de Holanda, "Prefácio"; Sérgio Buarque de Holanda, "As colônias de parceria," in O Brasil Monárquico: reações e transições 5, t. II, org. Sérgio Buarque de Holanda (Rio de Janeiro: Bertrand Brasil: 2004), 289-307; Dean, Rio Claro, cap. 4; Viotti da Costa, Da monarquia, cap. 5; e, mais recentemente, Bruno Gabriel Witzel de Souza, "Imigração alemã e mercado de trabalho na cafeicultura paulista: um estudo quantitativo dos contratos de parceria," História Econômica \& História de Empresas 15, n. 2 (jul./dez. 2012).
} 
também dividir com o fazendeiro a metade do lucro advindo da venda da produção que plantasse para consumo próprio e que excedesse o necessário para subsistência. ${ }^{15} \mathrm{~A}$ partir deste momento, a fazenda Ibicaba tornou-se uma referência na província, chegando a colônia de imigrantes a abrigar 900 estrangeiros. $^{16}$

Nos anos seguintes, ao menos 41 colônias foram fundadas por iniciativa particular de fazendeiros de São Paulo, motivados em grande parte pelo o fim do tráfico de escravos decretado em 1850 e possível escassez de braços para a fazenda. ${ }^{17}$ No entanto, os problemas com a parceria, com colonos queixando-se dos maus tratos recebidos pelos fazendeiros, da falta de pagamento pelas colheitas, das dívidas acumuladas - visto que deveriam devolver os adiantamentos feitos pelos fazendeiros por seu transporte e alojamento - levaram a revoltas e protestos em diversas colônias. O episódio mais conhecido foi a revolta de Ibicaba, em 1857, que sinalizou o declínio do sistema de parceria. ${ }^{18}$ As colônias particulares fundadas nesse período e nas décadas seguintes sofreram os mesmos problemas que levaram ao fim do sistema de parceria. Entre outras razões, a mentalidade escravista dominava os fazendeiros e se traduzia em atitudes e contratos de trabalho celebrados com os imigrantes. ${ }^{19}$

Anos mais tarde, em debate com Joaquim Bonifácio do Amaral sobre a política imigratória, José Vergueiro, filho do senador Vergueiro, sustentou que o sistema de parceria promovido por seu pai teria sido apenas um passo em direção a uma onda imigratória espontânea na província de São Paulo. O resultado poderia ser visto, segundo José Vergueiro, com o sucesso econômico alcançado por diversos imigrantes que deixaram a fazenda Ibicaba para se estabelecerem como proprietários na região. ${ }^{20}$ $\mathrm{Na}$ época, José Vergueiro chegou a argumentar que a fazenda Angélica, outra propriedade da família, havia sido comprada com o explícito objetivo de ser retalhada e vendida em lotes para imigrantes. No entanto, como aponta Bruno Witzel de Souza, a fazenda foi cultivada com mão de obra escrava e parceiros estrangeiros desde a época

\footnotetext{
15 Forjaz, O Senador; Verena Stolcke e Michael Hall, "A introdução do trabalho livre nas fazendas de café de São Paulo,” Revista Brasileira de História. 6 (set,/1983). Viotti da Costa, Da monarquia, cap. 5; Buarque de Holanda "As colônias de parceria," 245-60; Lamounier, Between, 156-61.

${ }^{16}$ Dean, Rio Claro, 98.

${ }^{17}$ Holanda, "Prefácio," 27.

${ }^{18}$ Sobre a revolta de Ibicaba, ver: Thomas Davatz, Memorias de um colono no Brasil (1850) (São Paulo: Martins, 1951). Para Michael Hall, o maior motivo para o fracasso das primeiras experiências em São Paulo era que o trabalhador livre estava sendo empregado juntamente com os escravos nos grandes latifúndios. Hall, "Origins."

${ }^{19}$ Stolcke e Hall, "A introdução"; Lamounier, Between, 156-61.

${ }^{20}$ Dean, Rio Claro, 122-3; Witzel de Souza, "From bonded," 44, nota 102; Lanza, "E fizeram".
} 
da Vergueiro \& Cia. Quando ocorreu o mencionado debate com Bonifácio do Amaral, a fazenda Angélica encontrava-se penhorada junto ao London and Brazilian Bank. ${ }^{21}$ Talvez José Vergueiro tivesse percebido na época que teria sido mais vantajoso vender a fazenda em lotes a estrangeiros do que hipotecá-la e talvez perdê-la para o banco.

Em outro debate público, José Vergueiro chegou a dizer que as grandes propriedades eram vantajosas apenas para os poucos felizardos que eram seus proprietários: "Os pequenos estabelecimentos, a classe numerosa de pequenos proprietários", afirmava, era a que daria "a medida da felicidade de um povo, tornandoo enérgico, trabalhador, inteligente e rico". A divisão territorial, prosseguia, era "tão necessária ao progresso e desenvolvimento de uma nação, como a divisão do trabalho" e, só por via da imigração poderia o Brasil alcançar tão feliz resultado. ${ }^{22}$

Com a aprovação da Lei do Ventre Livre em 1871 e a certeza cada vez maior do fïm da escravidão, os temas da imigração e colonização voltaram à tona. Surgiram diversas associações e companhias colonizadoras com o objetivo de impulsionar a imigração, organizadas e subsidiadas pelos governos central e provincial. ${ }^{23}$ Ao longo da década de 1870, em parte também devido à expansão das ferrovias e ao aumento da produção cafeeira, foram aprovados decretos e leis dando apoio financeiro aos fazendeiros para a contratação de imigrantes. Os anos 1880 foram marcados pelo surgimento de sociedades dedicadas à promoção da imigração europeia e pela articulação entre o governo provincial e os cafeicultores na organização de uma estrutura para o serviço de imigração de São Paulo, responsável pela entrada massiva de imigrantes até o final dos anos 1920. A seguir, serão apresentadas duas sociedades que, a partir de suas orientações individuais, atuaram pressionando o governo provincial para a promoção da imigração, incluindo em um dos casos a defesa do acesso à terra pelos imigrantes.

\footnotetext{
${ }^{21}$ Um estudo detalhado da Fazenda Angélica sob a administração do London and Brazilian Bank foi feito por Joseph Martin Muhern, "After 1833: British Entanglement with Brazilian Slavery" (Doctoral thesis, Durham University, 2018), 262-99.

${ }^{22}$ Gazeta de Campinas, 10/04/1870, 2.

${ }^{23}$ Sobre as diversas companhias surgidas no período, ver: Paulo C. Gonçalves, "Mercadores de Braços. Riqueza e acumulação na organização da emigração europeia para o Novo Mundo" (Tese de Doutorado FFLCH/USP, São Paulo, 2008), 139-141; Maria Silvia C. B. Bassanezi et al, Repertório de legislação brasileira e paulista referente à imigração (São Paulo: Editora Unesp/Fapesp, 2008), 17-20.
} 


\subsubsection{A Sociedade de Imigração de São Paulo}

Em 25 de março de 1885 surgiu em São Paulo a Sociedade de Imigração de São Paulo (SISP), com o objetivo de difundir pela província os ideais da Sociedade Central Imigração (SCI), da qual era filial, e atuar em defesa da pequena propriedade e da promoção da imigração, sob a direção de José Vieira Couto de Magalhães e Antônio da Silva Prado. ${ }^{24}$ A Sociedade Central havia sido fundada no Rio de Janeiro em 1883 por representantes da classe média urbana que não se viam representados pelos interesses da elite latifundiária. Essa sociedade declarava como objetivo criar uma classe média rural sólida e estável, baseada na pequena propriedade de imigrantes europeus, que levariam o progresso à sociedade brasileira. ${ }^{25}$ Ao longo da existência da Sociedade Central, diversas sociedades filiais foram criadas nas capitais e no interior das províncias do país.

Pouco estudada e com poucos registros, a Sociedade de Imigração de São Paulo parece ter sido um capítulo esquecido na história da imigração paulista. ${ }^{26}$ As principais fontes para seu estudo são as atas das reuniões da Sociedade, publicadas nos boletins da Sociedade Central. A Sociedade de Imigração de São Paulo encarregava-se de fiscalizar e cobrar do governo provincial a promoção da imigração espontânea, o acolhimento e acomodação dos imigrantes chegados a São Paulo, a realização de propaganda da província, além de propor medidas para contratação e colocação dos imigrantes nas fazendas. ${ }^{27}$ Diante da Assembleia Provincial, a diretoria da Sociedade de Imigração de São Paulo apresentava relatórios de comissões formadas por seus membros com requerimentos que buscavam transformar a província em um local atraente aos

\footnotetext{
${ }^{24}$ Compuseram a Sociedade de Imigração de São Paulo: como presidente, o general Dr. José Viera Couto de Magalhães; Vice-Presidente Rapael de Aguiar Paes de Barros; $1^{\circ}$ secretário, Augusto Cesar Miranda Azevedo; $2^{\circ}$ secretário, Carlos Bolle; Tesoureiro: José Rempe; Diretores: João Adolpho Schritzmeyer, comendador José Duarte Rodrigues, Abilio Marques, Dr. Antonio da Silva Prado, Dr. Vieira De Carvalho, Dr. F. D'Agostini, Dr. Elias Chaves, Dr. Francisco Eugenio, Dr. Domingos Jaguaribe, Frederico Upton, Dr. Nicolao Queiroz, W. Frischer, Tenente-coronel Ignacio Gabriel Monteiro de Barros, Dr. Paulo Queiroz Francisco de Souza Paulista, João Batista de Mello e Oliveira, Dr. Eleoterio Prado, conselheiro Bento de Paula Souza, Antonio Paes de Barros, Dr. José Cerqueira Cesar, Dr. Francisco Aguiar de Barros, Dr. Martinho Prado Junior, J. Bryan e Benedicto Vieira Barboza.

${ }^{25}$ Michael Hall, "Reformadores de Classe Média no Império Brasileiro: A Sociedade Central de Imigração," Revista de História XXVII, v. LIII (1976); Sergio Luiz Monteiro Mesquita, "A Sociedade Central De Imigração e A Política Imigratória Brasileira (1883-1910)" (Dissertação de Mestrado, Universidade do Estado do Rio de Janeiro, 2000); Ângela Bernadete Lima, “"Nós declaramos guerra ao latifúndio!': Propostas, ações e ideais de imigração/colonização da Sociedade Central de Immigração (1883-1891)" (Dissertação de Mestrado, UFSC, 2015).

26 A SISP aparece mencionada em poucos trabalhos acadêmicos. Dentre eles, ver: Lima, "Nós Declaramos,", 218-221.

${ }^{27}$ A Província de São Paulo, 07/02/1885, 1; Correio Paulistano, 05/04/1885, 1; Correio Paulistano 14/04/1885, 2; Correio Paulistano, 03/05/1885, 3; A immigração, n. 10 (abr. 1885).
} 
imigrantes, com demandas como casamento civil, direitos aos estrangeiros que não fossem católicos e impostos sobre transmissão de propriedade e imposto territorial, visando o parcelamento das grandes propriedades e venda de pequenos lotes de terra. A Sociedade também intercedia por imigrantes em seus pleitos para recebimento de subsídio ou por disputas de lotes de terra nos núcleos coloniais. A questão do assentamento de imigrantes em pequenas propriedades foi discutida amplamente nas reuniões da Sociedade, ganhando a forma de requerimentos, pareceres e debates. ${ }^{28}$

Por vezes, houve casos em que os interesses da Sociedade Central e de sua filial paulista entraram em conflito. Em sessão de 4 julho de 1885, discutiu-se em reunião da Sociedade de Imigração de São Paulo um ofício enviado por Alfredo Taunay, um dos membros da Sociedade Central, pedindo que fosse rejeitado o modelo de contrato de imigração dos fazendeiros paulistas com companhias de colonização, por considerar que tais arranjos não contribuíam para a formação de uma corrente espontânea para fixação dos imigrantes. Um dos pontos centrais da política defendida pela Sociedade Central era justamente assentar imigrantes em pequenas propriedades para a formação de uma classe média rural, como visto antes. ${ }^{29}$ Em resposta, a diretoria da Sociedade de Imigração de São Paulo afirmou que não possuía relação com os indivíduos ou associações que celebravam contratos de introdução de imigrantes. Ainda que condenasse esses contratos, a Sociedade de Imigração de São Paulo não interferiria nos negócios dos que os adotassem, atuando apenas em favor dos imigrantes que viessem para a província quando houvesse abusos. ${ }^{30}$

As ideias da Sociedade Central e de sua filial paulista desagradavam os grandes cafeicultores paulistas, mais preocupados com uma solução rápida e eficaz para o problema de falta de braços nas fazendas do que com o povoamento da província por meio da venda ou concessão de pequenas propriedades a estrangeiros. As visões conflitantes sobre a política imigratória ideal levaram a divergências e cisão entre seus membros. Um grupo defendia a demarcação de terras públicas através de projetos de concessão e venda de terras devolutas a imigrantes; outro se dedicava a encontrar um caminho para complementar e depois substituir o trabalho escravo nas fazendas. Essa

\footnotetext{
${ }^{28}$ A Immigração, n. 21.

${ }^{29}$ Ver os discursos contidos nos primeiros boletins da Sociedade: A Immigração, n. 1-4 (dez. 1883 - ago. 1884); A Immigração, n. 17 (jan. 1886); A Immigração, n. 56 (abr. 1889). Outras fontes para o pensamento dos membros da sociedade sobre as questões agrárias são as obras que publicavam, como as de André Rebouças. Hall, "Origins," 54-5.

${ }^{30}$ A Immigração, n. 15 (nov. 1885), 2.
} 
divergência deu origem à Sociedade Promotora de Imigração (SPI), fundada com membros dissidentes da a Sociedade de Imigração de São Paulo. ${ }^{31}$

\subsubsection{A Sociedade Promotora de Imigração}

Em 1884, sob pressão dos cafeicultores diante do agravamento da crise do sistema escravista, o governo de São Paulo aprovou a Lei Provincial n. 28 de 29 de março de 1884, prevendo o custeio integral do valor da passagem paga a imigrantes europeus que viessem com suas famílias trabalhar nas fazendas. ${ }^{32}$ Com essa lei, a província lançava as bases da imigração em massa para São Paulo, concretizada nas décadas subsequentes. A Lei de 1884 abriu créditos para a imigração em duas frentes: 400 contos de réis para o pagamento de passagens a imigrantes destinados à grande fazenda e a núcleos coloniais e 200 contos de réis para a fundação de núcleos coloniais na província. ${ }^{33}$ Os recursos eram destinados apenas a famílias de imigrantes, visando atender à demanda dos cafeicultores por trabalho, sob o argumento de que essa seria a melhor forma de garantir a permanência dos imigrantes em São Paulo.

Em 1885, a Lei Provincial n. 14, de 11 de fevereiro, passou a especificar melhor a quais imigrantes se destinavam os subsídios: apenas imigrantes casados ou com filhos, que viessem estabelecer-se na província, ou solteiros em companhias de irmãos, avós ou tios. A lei possibilitou, também, a concessão de verbas às companhias de navegação, empresas ou particulares que se propusessem a transportar os imigrantes da Europa para o Brasil, retirando a obrigatoriedade do pagamento das despesas com passagens diretamente aos que emigrassem para a província. ${ }^{34}$

\footnotetext{
${ }^{31}$ Lima, "Nós Declaramos," 218-9. Ao que parece, a SPI e a SISP coexistiram durante certo período. Nas atas da Sociedade Central de Imigração de 10 de julho de 1886 consta que "A directoria decidiu officiar á Sociedade de Inimigração do S. Paulo, perguntando qual o pensamento que domina aquelle vasto empreendimento (SPI)", questionando como se daria a introdução de imigrantes proposta pela Promotora e expressando preocupação pelo programa não mencionar a pequena propriedade como forma de fixar o imigrante à terra. A Immigração, n. 23.

32 Lei n. 28, de 29 de marco de 1884. Disponível em: https://www.al.sp.gov.br/repositorio/legislacao/lei/1884/lei-28-29.03.1884.html, Acesso em: 28 ago. 2018.

${ }^{33}$ Por meio dessa lei e do crédito concedido à criação de núcleos coloniais, foram fundados na província o núcleo colonial do Cascalho, em Rio Claro, e o núcleo de Cannas, em Lorena. SÃO PAULO, Relatorio com que o Exmo. Sr. Dr. José Luiz de Almeida Couto, presidente da província de São Paulo, passou a administração ao 1 Vice-Presidente Exmo. Sr. Dr. Francisco Antonio de Souza Queiroz Filho (São Paulo: Typographia do Correio Paulistano, 1886).

${ }^{34}$ Lei n. ${ }^{\circ} 14$ de 11 de fevereiro de 1885 . Disponível em: http://www.al.sp.gov.br/repositorio/legislacao/lei/1885/lei-14-11.02.1885.html. Acessado em 28 ago. 2018.
} 
Os cafeicultores paulistas aproveitaram a Lei n. 14 de 1885 e articularam-se para controlar o processo imigratório na província por meio da criação da Sociedade Promotora de Imigração. ${ }^{35}$ Recrutar, transportar e distribuir mão de obra imigrante, pagar os subsídios, gerenciar a Hospedaria de Imigrantes e a organização da propaganda para atração de imigrantes estavam entre os atributos da nova entidade. ${ }^{36}$ Fundada em junho de 1886, a Sociedade Promotora foi composta por membros de todos os partidos políticos do governo de São Paulo e por fazendeiros proeminentes. ${ }^{37}$ A nova organização era uma prova de que os interesses da imigração se sobrepunham aos embates políticos entre conservadores e republicanos. ${ }^{38}$

Mais do que organizar o programa imigratório paulista, como observou Thomas Holloway, uma das funções mais importantes da Sociedade Promotora acabou sendo a de dar continuidade à política imigratória mesmo durante o período de transformação política desde a queda do Império até o estabelecimento definitivo da República com a Constituição de $1891 .{ }^{39}$ Sendo autorizada a assinar contratos com o governo de São Paulo e contratar a introdução de imigrantes com companhias particulares, a Sociedade Promotora foi responsável por organizar o serviço imigratório da província de São Paulo, tornando-se, na prática, o órgão do governo provincial responsável por todos os temas relacionados à imigração, demonstrando a grande simbiose existente entre o poder público e os interesses privados. ${ }^{40}$ A questão da colonização, no entanto, diferentemente do que vinha sendo feito pela antiga Sociedade de Imigração de São Paulo, acabou sendo relegada a um plano secundário pela Sociedade Promotora, subordinada que foi à política imigratória. ${ }^{41}$

\footnotetext{
${ }^{35}$ Gonçalves, "Mercadores," 183-4.

${ }^{36}$ Sociedade Promotora de Immigração de S. Paulo, Relatorio da Directoria ao Exm. Sr. Conde de Parnahyba, presidente da Provincia de S. Paulo (São Paulo: Typ. Jorge Seckler \& Comp. 1888), 24.

${ }^{37}$ Dentre estes: Benedicto Barbosa, conservador; Rafael Aguiar Paes de Barros e Martinho Prado Jr., cafeicultores e membros do Partido Republicano; Nicolau de Souza Queiroz e Rodrigo Lobato, importantes nomes do Partido Liberal. Martinho Prado, Antonio Queiroz Telles e o Visconde de Parnaíba assumiram a diretoria da sociedade.

${ }^{38}$ Confirmação disso é o fato de Queiroz Telles ter incluído o nome de Martinho Prado, membro do Partido Republicano, na lista de deputados candidatos às eleições provinciais do Partido Conservador. Ao ser questionado, Telles afirmou que "é dele que eu preciso na Assembleia. É o único no momento capaz de ali defender os interesses da immigração". Adelino R. Ricciardi, "Parnaíba, o pioneiro da imigração," Revista do Arquivo Municipal XLIV (fev. 1938).

${ }^{39}$ Holloway, Imigrantes, 66.

${ }^{40}$ São Paulo, Relatorio apresentado á Assembléa Legislativa Provincial de São Paulo pelo presidente da provincia, Barão do Parnahyba, no dia 17 de janeiro de 1887 (São Paulo: Typ. a Vapor de Jortge Seckler \& Comp., 1887), 125.

${ }^{41}$ Mesquita, "A Sociedade," 32.
} 
De fato, a Sociedade Promotora caracterizou-se desde o princípio como um projeto para atrair famílias de imigrantes pobres, destinados a substituírem a mão de obra escrava no café e a evitarem uma possível escassez de braços. Essa visão tornou-se dominante na Sociedade e seus membros defendiam que apenas os imigrantes sem recursos e amparados pelos favores concedidos pelo governo escolheriam migrar para São Paulo. ${ }^{42}$

Martinho Prado Jr., importante cafeicultor, político republicano e um dos fundadores da Sociedade Promotora, enfatizou com clareza a importância das famílias pobres para o processo imigratório de São Paulo. O republicano opôs-se à expansão dos subsídios governamentais para outros imigrantes que não os mais pobres da Europa. Sua argumentação ecoava o raciocínio de seus pares: imigrantes com capitais não tinham o que fazer na província e seriam inúteis para os interesses dos fazendeiros. ${ }^{43}$ Segundo esta visão, o acesso à terra pelo imigrante viria após um período de trabalho, aclimatação e acumulação de capitais - ou seja, o mesmo defendido pelo Senador Vergueiro desde 1827. No entanto, assim como José Vergueiro o fez na década de 1870, esses novos políticos usavam exemplos de ascensão social por meio da compra de terra pelos imigrantes como propaganda para outros estrangeiros interessados em imigrar para São Paulo. ${ }^{44}$

Os subsídios pagos pela Sociedade Promotora destinavam-se a dois grupos de imigrantes: aqueles chamados por parentes já estabelecidos na província ou às famílias de imigrantes espontâneos. ${ }^{45}$ Essa última categoria, na documentação registrada pela

\footnotetext{
${ }^{42}$ SPI, "Relatório apresentado ao Ilmo. Exmo. Sr. Visconde de Parnahyba Presidente da Província de São Paulo pela Sociedade Promotora de Immigração," in Exposição com que o Exmo. Sr. Visconde de Parnahyba passou a administração da Província de São Paulo ao Exm. Sr. Dr. Francisco de Paula Rodrigues Alves Presidente desta Provincia no dia 19 de novembro de 1887 (São Paulo: Typ. Jorge Seckler \& Comp, 1888), Anexo A4.

${ }^{43}$ SPI, Relatorio da Directoria ao Exm. Sr. Conde de Parnahyba, presidente da Provincia de S. Paulo (São Paulo: Typ. Jorge Seckler \& Comp, 1888).

${ }^{44}$ Mesmo autoridades estrangeiras divulgavam essas informações. O Ministro Belga no Rio de Janeiro discorreu sobre as condições facilitadas para que estrangeiros adquirissem terras em São Paulo e a prosperidade dessas propriedades. Advertia, no entanto, que era preferível que o imigrante buscasse trabalho primeiro nas fazendas, independentemente de sua condição, pela necessidade de aclimatação. Edouard De Grelle, Étude du Brésil (Rapport Official) (Bruxelas, 1888), 12 apud Eduardo Prado, "A imigração no Brasil," in Secretaria da Agricultura, Indústria e Comércio, Boletim do Serviço de Imigração e Colonização n. 4 (São Paulo, dez. 1941): 111-3. Em outro relatório, um ministro italiano repetiu o mesmo, completando que uma família numerosa apta para o trabalho agrícola acumularia capital suficiente para adquirir terras em um período de tempo não muito longo. Correio Paulistano, 02/07/1911. ${ }^{45}$ A justificativa para essa escolha, segundo o relatório apresentado pela SPI ao Barão de Parnaíba em 1887, era garantir a qualidade do imigrante, evitando incorrer nos erros passados cometidos pelo governo, empresas e particulares. O relatório escrito por Martinho Prado Jr. destacava o sucesso da medida. Após publicação nos jornais da província, convidando os estrangeiros já estabelecidos a solicitarem à Diretoria
} 
Sociedade Promotora, referia-se àqueles imigrantes que procuravam por conta própria $\mathrm{o}$ serviço dos agentes de imigração das companhias de navegação para o transporte até São Paulo. ${ }^{46}$ No caso dos espontâneos, o pagamento somente seria feito para famílias, desestimulando a imigração de solteiros. ${ }^{47}$ Os pagamentos do subsídio aos imigrantes chamados por parentes teriam o propósito também de fiscalizar a qualidade dos que deveriam dirigir-se para São Paulo. ${ }^{48}$

Nos dez anos em que esteve em funcionamento, de 1886 a 1895, foram celebrados seis contratos de introdução de imigrantes entre o governo de São Paulo e a Sociedade Promotora, pelos quais foram introduzidos mais de 220.000 imigrantes europeus no estado e província. ${ }^{49}$ Nesse mesmo período, entraram em São Paulo mais de 621.000 estrangeiros, sendo 430.000 com subsídios. ${ }^{50}$

O sucesso do sistema de subsídios paulista atraiu diversas críticas por parte da Sociedade Central e respostas por parte da Sociedade Promotora e do governo de São Paulo. Os embates giraram em torno do fato da política privilegiar a imigração destinada para o trabalho nas fazendas e não para o estabelecimento em pequena propriedade. Em ofício de 13 de agosto de 1889 dirigido ao presidente da província de São Paulo, membros da Diretoria da Sociedade Central criticaram a forma como a imigração vinha sendo conduzida na província. ${ }^{51} \mathrm{O}$ sistema de subsídios e de trabalho assalariado, segundo o ofício, havia saturado o mercado de trabalho local e não contribuía para o que a Sociedade Promotora julgava ser o objetivo maior da imigração para o país, que era a fixação dos imigrantes como pequenos proprietários. Em períodos

\footnotetext{
passagens gratuitas a seus parentes, 36.000 pedidos foram recebidos. Tal fato, segundo o relatório, seria "a mais significativa prova, irrecusavel attestado, de que na Provincia de S. Paulo o immigrante é feliz, vive contente, desejando que deste bem estar venham participar aquelles que lhe são caros". SPI, Relatorio, 6.

${ }^{46}$ Katia C. Petri, “'Mandem vir seus parentes': a Sociedade Promotora de Imigração em São Paulo (18861896)" (Dissertação de Mestrado, PUCSP, 2010), 62-3.

47 Conforme consta no primeiro contrato firmado para introdução de 6.000 imigrantes pela SPI, autorizado pelo governo provincial, com Angelo Fiorita: "os imigrantes expontaneos constituirão família de seguinte modo: primeiro marido e mulher com ou sem filhos ou enteados; segundo) marido ou mulher com filhos ou enteados; terceiro) viúvo ou viúva com filhos ou enteados; quarto) avó ou avô com netos ou descendentes; quinto) tios ou tias com seus sobrinhos, e sexto) irmão ou irmã com seus irmãos, de conformidade com as leis provinciais. O parentesco será provado pelos passaportes e na falta d'estes por meio de documentos das autoridades dos paízes de onde immigraram, uma vez que sejam assinados pelos consoles brasileiros." SPI, Actas... Manuscrito. Arquivo do Estado de São Paulo (AESP). Fundo Imigração, C05529.

${ }^{48}$ São Paulo, Relatorio... Barão do Parnahyba, 1887, 125.

${ }^{49}$ Relatorio da directoria da Sociedade Promotora de Immigração em 31 de dezembro de 1895 apud Hall, "Origins," 98.

${ }^{50}$ Relatórios da Secretaria da Agricultura de São Paulo, vários anos.

${ }^{51}$ O ofício foi assinado por Alfredo Taunay, André Rebouças, Carlos Raynsfor, Wenceslau Guimarães, Octavio Haupt, Luiz Magalhães e Henrique de Sanson. A immigração, n. 60 (ago. 1889).
} 
de colheita, São Paulo atuava como ímã de estrangeiros que buscavam ganhos rápidos nas fazendas. Quando acabava a colheita, a província vivenciava uma fuga de imigrantes do campo para os municípios e para o exterior. Segundo a Sociedade Central, os grandes espaços vazios na província de São Paulo, ocupados por propriedades improdutivas, seriam propícios para a fixação de imigrantes. A província deveria realizar reformas visando esse objetivo. ${ }^{52}$

Em uma clara crítica aos membros da Sociedade Central, o Barão de Parnaíba afirmou que os que eram contrários à grande propriedade não entendiam as circunstâncias em que se achava o país e, mais especificamente, São Paulo. O problema, em sua visão, residia no fato de que o imigrante com recursos não se arriscaria no Brasil; somente os imigrantes trabalhadores pobres, desprovidos de capitais, buscando uma vida melhor, é que se aventurariam no país. Dessa forma, defendia o Barão, o sistema implementado em São Paulo seria o mais adequado para as necessidades da província e o mais vantajoso ao imigrante, já que estes chegariam sem dívidas, com trabalho definido e com moradia e alimentação nas fazendas, recebendo, assim, o aprendizado necessário para se tornar proprietário independente. ${ }^{53}$

As desavenças entre as duas Sociedades se estenderam durante toda a sua existência. Nota-se, pelos embates travados, pelos discursos proferidos em jornais e nas atas de suas reuniões, a defesa de dois princípios bem marcados para a imigração. ${ }^{54}$ Por um lado, havia os intelectuais e a elite urbana da capital do país clamando por mudanças na estrutura social e cultural do Brasil e vendo nos imigrantes os agentes civilizadores e transformadores da realidade brasileira. Por outro, os fazendeiros paulistas, preocupados em manter a grande propriedade rural e a exportação, que viam os imigrantes como fonte de mão de obra para as fazendas em um cenário de fim da escravidão. Apesar de ter prevalecido a última corrente, o ideário da pequena propriedade encontrou adeptos dentro do governo de São Paulo e, nos anos seguintes, os próprios fazendeiros perceberam que poderiam se beneficiar da atração de imigrantes como pequenos proprietários.

A queda do Império em 1889 foi acompanhada por mudanças significativas na realidade social e política do país. No entanto, as transformações ocorridas na transição

\footnotetext{
${ }^{52}$ A immigração, n. 60 (ago. 1889).

${ }^{53}$ São Paulo, Relatório... Barão do Parnahyba, 17 de janeiro de 1887.

${ }^{54}$ A immigração, n. 74 (dez. 1890).
} 
para a República foram insuficientes para romper com a antiga ordem tradicional conservadora no tocante à estrutura fundiária do país. A Constituição aprovada em 1891 garantiu a autonomia para os estados legislarem livremente sobre as terras devolutas e a imigração. O que se notou, daí em diante, foi uma continuidade das políticas fundiárias do período imperial, como será visto na próxima seção.

\subsection{A legislação fundiária do estado de São Paulo}

Com a queda do Império em 1889 e a promulgação da primeira Constituição republicana em 1891, cada estado teve ampla liberdade para legislar sobre suas terras devolutas e cada unidade federativa passou a organizar da forma que melhor conviesse sua política de terras e colonização. ${ }^{55} \mathrm{Na}$ realidade, apenas os estados com condições financeiras puderam dar continuidade às políticas de subsídio à imigração e, na época, tal fato significou que apenas São Paulo conseguiria prosseguir financiando o transporte de imigrantes. ${ }^{56}$

Mesmo dispondo de autonomia garantida pela Constituição de 1891, o que se viu nos estados foi uma continuidade com a política de terras do Império. ${ }^{57}$ A primeira Lei de Terras brasileira foi aprovada em 1850 e vigorou até a queda do Império. ${ }^{58}$ Essa lei buscava ordenar a situação fundiária caótica herdada do período colonial e, ao mesmo tempo, fomentar a imigração. ${ }^{59}$ Por ela ficava estabelecido que a alienação da terra ocorreria apenas por meio da venda, o que dificultaria a posse da terra por escravos libertos, livres pobres e imigrantes recém-chegados. ${ }^{60} \mathrm{Um}$ dos principais objetivos da Lei de Terras era a legitimação das posses, processo que seria realizado por via

\footnotetext{
55 Sobre a política de terras nos estados ver, dentre outros: Lígia Osório Silva, Terras devolutas $e$ latifúndio: efeitos da lei de 1850 (Campinas: Editora da UNICAMP, 1996), cap. 8; Almir Teubl Sanches, "A questão de terras no início da República: o Registro Torrens e sua (in)aplicação" (Dissertação de Mestrado, FDUSP, 2008), cap. 7; Petrone, "Imigração," 98-9.

56 Warren Dean, "Latifundia and Land Policy in Nineteenth-Century Brazil," The Hispanic American Historical Review 51, n. 4 (Nov. 1971): 624.

${ }^{57}$ Sobre a política de terras no Império, ver: Rui Cirne Lima, Pequena história territorial do Brasil: sesmarias e terras devolutas (Goiânia: Ed. UFG, 2002), 11-33; Silva, Terras, 11-57.

${ }^{58}$ Brasil, Lei n. 601, de 18 de setembro de 1850. Dispõe sobre as terras devolutas do Império, Disponível em: http://www.planalto.gov.br/ccivil_03/LEIS/L0601-1850.htm, Acesso em: 30 mar. 2017.

59 A lei atuava na imigração de duas formas: 1) a regularização da propriedade da terra garantiria segurança jurídica aos estrangeiros que almejavam um dia tornarem-se proprietários; 2) a receita da venda das terras devolutas seria destinada a financiar a vinda de imigrantes com o objetivo de suprir braços para as lavouras. Silva, Terras, 115-217; Márcia Maria Menendes Motta, Nas fronteiras do poder: conflito e direito à terra no Brasil do século XIX (Rio de Janeiro: Vício de Leitura, 1998), 159-88.

${ }^{60}$ Silva, Terras, 247-52.
} 
administrativa. ${ }^{61}$ Os processos de legitimação seriam julgados, em última instância, pelos presidentes das províncias, que passariam a ocupar uma posição central nas questões relacionadas à terra. Após a Constituição republicana estabelecer a eleição direta dos executivos estaduais, as elites políticas dos estados mais poderosos dedicaram-se a preservar o controle sobre as situações locais. ${ }^{62}$ Pouco ou nenhum espaço foi concedido aos grupos dissidentes ou que reivindicassem antigas bandeiras de autonomia e descentralização política. Não era do interesse dos grandes proprietários retirar esse poder de decisão sobre a legitimação das posses das mãos dos governantes e nem conduzir a mudanças drásticas no status quo criado pela Lei de Terras de 1850.

Em São Paulo, as primeiras discussões sobre um projeto de lei estadual de terras ocorreram em maio de 1893, quando o senador Francisco de Salles Oliveira Júnior apresentou um projeto sobre as terras devolutas do estado e requereu que a matéria fosse submetida ao estudo de uma comissão especial composta por membros da câmara e do Senado de São Paulo, a fim de apresentar parecer sobre o assunto. ${ }^{63}$ Os debates sobre o projeto da primeira lei de terras paulista se estenderam por mais de dois anos até a aprovação do texto final em junho de 1895.

Para o presidente da Câmara do estado de São Paulo, Luiz Piza, o projeto era apenas um conjunto de disposições bem elaboradas, semelhante à Lei de $1850 \mathrm{em}$ diversos pontos, mas se afastava da mesma no espírito liberal por não facilitar a aquisição das terras devolutas e nem o povoamento do estado de São Paulo. ${ }^{64} \mathrm{O}$ projeto previa a reserva de terras devolutas para a fundação de núcleos coloniais de povoamento com nacionais ou estrangeiros; limitava o tamanho das propriedades a serem alienadas com o objetivo de se evitar a formação de grandes propriedades; estabelecia que a um mesmo comprador não fossem vendidas terras devolutas confinantes com o lote escolhido e previa que o maior lote de terras devolutas vendido não poderia exceder 500 hectares em terras virgens, matas ou de cultura, 4.000 hectares em terras de campo e 50

\footnotetext{
${ }^{61}$ Desde o período colonial ocorria no Brasil um problema que se agravou com o fim das doações de sesmarias em 1823: o apossamento. Os que não obtinham sesmarias do governo acabavam assentando-se em terras não reclamadas pela coroa já que, ainda que fosse ilegal, raramente ocorreria a imposição da lei: os posseiros não eram notados a não ser que aquele espaço fosse alienado. A Lei de Terras de 1850, ao estabelecer a compra como única forma de alienação das terras públicas, visava justamente acabar com essa sistemática de apossamento. No entanto, os intentos falharam e essa prática estendeu-se também do Império até a Primeira República. Silva, Terras, 79-94.

62 Joaquim Assis Brasil, Do Governo Presidencial na Republica Brasileira (Lisboa: Companhia Editora Nacional, 1896), 14-5; Silva, Terras, 255-75.

63 “Assembleia Legislativa,” sessão de 20/05/1893, Correio Paulistano, 22/05/1893, 1.

64 “Assembleia Legislativa,” sessão de 02/07/1894, Correio Paulistano, 04/07/1894, 2.
} 
hectares em lotes suburbanos. O projeto definia também o preço mínimo para a terra ser vendida, sendo de $10 \$ 000$ o hectare em terra de cultura, $2 \$ 000$ em terras de campo e $20 \$ 000$ os lotes suburbanos. ${ }^{65}$

A primeira lei de terras de São Paulo, Lei n. 323, foi, por fim, promulgada em 22 de junho de 1895, dispondo sobre terras devolutas, ocupação do solo, medição, demarcação e aquisição; legitimação e revalidação de posses e concessões e discriminação do domínio público do particular no estado. ${ }^{66}$ Além de tentar limitar o tamanho das novas propriedades ao fixar a extensão máxima dos lotes a serem vendidos, o tamanho das posses a serem legitimadas, e de prever a reserva de terras devolutas para a fundação de núcleos coloniais, a lei não trazia nenhuma medida específica para a promoção da pequena propriedade entre nacionais ou para a colocação de imigrantes como proprietários de terras.

Ainda assim, a Lei n. 323 de 1895 foi considerada muito rigorosa com os possuidores de terras. Apesar de reconhecer a legalidade dos posseiros e permitir o registro de suas propriedades, a lei mantinha os prazos estabelecidos pela Lei de Terras de 1850 para a legitimação das posses e revalidação das sesmarias. Bastaria o demandante apresentar uma prova da posse da terra ${ }^{67}$ Possuidores e agricultores, capitalistas e políticos interessados nas terras recém-transferidas para a posse do estado como devolutas sentiram-se prejudicados e pressionaram o governo por uma legislação mais favorável a eles. Ainda em abril de 1895, os moradores da Vila de Campos Novos do Paranapanema enviaram uma representação ao presidente da Câmara de São Paulo sobre "os grandes males" que o então projeto em discussão traria para a região. Segundo o documento, os moradores da comarca estariam sujeitos, nos termos da lei, à legitimação de suas terras, provenientes de uma grande posse registrada à época da Lei de 1850 e que havia desde então sido vendida em pequenos lotes. Os donos das terras incorreriam grandes despesas para legitimação das mesmas, com os quais não poderiam arcar, correndo o risco de perderem suas propriedades. Os proprietários, julgando a lei muito dura, requeriam que o governo estadual mantivesse as posses sem a necessidade de legitimação, "visto o tempo longo de sua ocupação". Outro ponto levantado por esses

\footnotetext{
65 "Projecto de Lei de Terras Devolutas," Correio Paulistano, 21/06/1894, 2-3.

66 São Paulo, Lei n. 323 de 22 de junho de 1895, Disponível em https://www.al.sp.gov.br/repositorio/legislacao/lei/1895/lei-323-22.06.1895.html, Acesso em: 22 abr. 2018. Pela lei, seriam terras públicas todas aquelas que não estivessem sob domínio privado por título legítimo até a data da Lei de Terras de 1850 ou de seu regulamento de 1854. Dessa forma, o governo buscava manter os prazos estabelecidos pela lei imperial para que os posseiros legitimassem suas terras.

${ }^{67}$ São Paulo, Lei n. 323.
} 
posseiros era em relação ao valor estabelecido na lei para a venda das terras devolutas, considerado demasiado alto, e que, somado aos custos de medição a cargo dos compradores, encareceria demasiadamente os lotes. ${ }^{68}$

A julgada severidade com que a Lei n. 323 tratava das questões das posses e revalidações e aquisição de terras devolutas fez com que, poucos meses após ter sido promulgado o seu regulamento, um novo projeto de lei de terras fosse proposto, alterando vários pontos tanto da lei quanto de sua implementação. ${ }^{69}$ As principais alterações do novo projeto visavam abrandar o dito rigor da primeira lei de terras do estado de São Paulo. Dentre as propostas, ficava estipulado que seriam duplicadas tanto a área máxima das posses legitimáveis quanto dos terrenos a serem vendidos em hasta pública, além de reduzidas pela metade a taxa por hectare da terra nos processos de legitimação e o preço mínimo de venda das terras devolutas. O projeto acabou arquivado no mesmo ano, mas foi retomado para discussão em 1898.

Em abril de 1898, José Alves de Cerqueira César apresentou outro projeto de lei no Senado de São Paulo modificando a Lei n. 323 de 1895. Dentre as novidades trazidas por esse projeto estava a taxação progressiva das áreas de posses a serem legitimadas, visando limitar o seu tamanho. Esse ponto foi alvo de protestos pelos donos de terras, em artigos publicados nos jornais O Estado de São Paulo e Correio Paulistano por considerarem a taxação "um erro grave e imperdoável". ${ }^{70} \mathrm{O}$ autor dos artigos defendia que, em vez de taxar as grandes propriedades como forma de defesa da pequena propriedade, o governo deveria dotar as terras de estradas e vias de comunicação com os centros urbanos e com as estradas de ferro para então se proceder à divisão das propriedades. Tal preocupação teve eco dentro do governo. Nas discussões do projeto no Senado de São Paulo, o senador José Luis de Almeida Nogueira posicionou-se contra a aprovação da tabela de taxação progressiva por considerar que com ela o projeto aumentaria o rigor da legislação quando o objetivo era justamente o contrário e

\footnotetext{
${ }^{68}$ Assembleia Legislativa de São Paulo (ALESP). Representação dos habitantes da vila de Campos Novos do Paranapanena sobre terras devolutas naquela localidade. 19 de abril de 1895. Disponível em: https://www.al.sp.gov.br/repositorioAH/Acervo/Alesp/Documentos/129/0015_1893.pdf Acesso em: 19 mai. 2018.

${ }^{69}$ ALESP, Projeto n. 206 de 1896. Manda executar com alterações a Lei n. 323 de 22 de junho de 1895 e respectivo regulamento $n .343$ de 10 de março de 1896, Disponível em: https://www.al.sp.gov.br/repositorioAH/Acervo/Alesp/Documentos/C_lt024/0206_1896.pdf, Acesso em: 22 mai. 2018

${ }^{70}$ O Estado de São Paulo, 30/04/1898, 3.
} 
por defender que qualquer taxação deveria incidir somente sobre as porções incultas das propriedades. $^{71}$

As comissões de Constituição e Legislação e Terras Públicas do congresso estadual de São Paulo decidiram unificar o projeto n. 206 de 1896 da Câmara estadual com o projeto do senador Cerqueira César e oferecer uma nova versão para debate que abarcaria ambos. As discussões no Senado se estenderam durante todo o ano de 1898. Novamente a questão da pequena propriedade foi discutida apenas indiretamente, como, por exemplo, no questionamento feito por Antônio Candido Rodrigues sobre a retomada da ideia de se reduzir os preços das terras e aumentar a área máxima dos lotes a serem vendidos. Para o senador, não haveria vantagens para o governo em dispor de grandes extensões territoriais, devendo as terras devolutas serem vendidas em pequenas parcelas. $^{72}$

Outras ideias originais surgiram dos debates dessa nova proposta de lei de terras. Uma delas foi apresentada por Ezequiel Ramos. O senador propunha que fosse extinto o imposto de exportação que recaía sobre os fazendeiros e fosse substituído por um imposto territorial. Para sua implementação, o senador apresentou aditivos ao projeto em discussão, visando a criação de um registro de terras do estado. Os possuidores ou proprietários ficariam obrigados a registrar suas posses ou propriedades nos cartórios de hipotecas das comarcas onde estivessem localizadas suas propriedades. A ideia seria criar um cadastro geral de terras do estado, contendo dados minuciosos das propriedades e, a partir deles, estabelecer o imposto territorial. ${ }^{73}$ Os aditivos, postos em votação, acabaram rejeitados.

Por fim, a Lei n. 545, aprovada em 2 de agosto de 1898, deixou de tratar da pequena propriedade e nada especificou em relação aos núcleos coloniais, como fazia a Lei n. 323 de 1895. A nova lei de terras do estado de São Paulo foi permissiva com os posseiros, prevendo a legitimação automática das posses que tivessem título anterior a 1878 e das terras em posse particular com morada habitual e cultura efetiva desde 1868 , bem como a legitimação das posses de primeira ocupação estabelecida até a promulgação da Lei n. $323 .^{74}$ Toda a área contida nos títulos ou, na falta dessa

\footnotetext{
71 “Assembleia Legislativa," Senado, sessão de 14/06/1898, Correio Paulistano, 15/06/1898, 1-2.

72 “Assembleia Legislativa," Senado, sessão de 18/06/1898, Correio Paulistano, 22/06/1898, 1-2.

73 “Assembleia Legislativa," Senado, sessão de 27/06/1898, Correio Paulistano, 07/07/1898, 2.

${ }^{74}$ São Paulo, Lei n. 545 de 2 de agosto de 1898, Disponível em: https://www.al.sp.gov.br/norma/64636, Acesso em: 22 jun. 2018.
} 
informação, a área ocupada pelo posseiro mais duas vezes, até o máximo de 2.000 hectares, seria legalizada. Posses ocorridas após 1895 estariam em conflito com a lei; no entanto, os posseiros nessas condições que estivessem cultivando a terra teriam prioridade na compra das mesmas quando estas fossem postas em leilão. ${ }^{75} \mathrm{Ou}$ seja, com a Lei n. 545 de 1898, a posse de terras devolutas tornou-se um elemento central da legislação de propriedade fundiária de São Paulo. Todas as posses realizadas entre 1854 e 1895 tornaram-se passíveis de serem legitimadas praticamente de forma automática.

A segunda lei de terras paulista só entrou em vigor em 1900, quando foi promulgado seu regulamento. Através dele, criou-se o Registro Público das Terras na sede das comarcas e determinou-se o registro obrigatório das terras devolutas, dos títulos de aquisição de terras devolutas e das sentenças de legitimação de posses e revalidação de sesmarias expedidas pelo estado. ${ }^{76} \mathrm{O}$ mesmo preceito da Lei de Terras de 1850 se aplicava aqui: sendo procedido o registro das terras particulares, o estado poderia ter conhecimento de quais terras estavam sob sua jurisdição. Da mesma forma que aconteceu com a Lei de Terras, o regulamento teve efeito prático limitado. ${ }^{77}$

Durante o primeiro ano que a Lei n. 545 de 1898 vigorou foram registradas apenas as terras que não estavam sujeitas aos processos de legitimação ou revalidação. Ao que parece, os proprietários particulares preocuparam-se com o registro, estando esse interesse ligado à grande expansão cafeeira que São Paulo vivia nos primeiros anos do século XX. Como consequência deste período, a terra valorizou-se e a legitimação de posses tornou-se urgente como segurança jurídica. O interesse econômico advindo do café fez com que o registro das propriedades de terras fosse encarado com mais seriedade, ao menos pelos particulares que não se encontravam em situação inteiramente irregular. ${ }^{78}$

O grande problema não era a falta de interesse do governo de São Paulo em determinar suas terras públicas ou facilitar os meios para que os posseiros legalizassem suas propriedades, dadas as benesses concedidas aos posseiros como desejavam as elites rurais. Como observou o secretário da Agricultura do governo de São Paulo, em

\footnotetext{
${ }^{75}$ São Paulo, Lei n. 545.

${ }^{76} \mathrm{O}$ governo deveria registrar suas próprias terras, o que significava que a terra seria regida pelo direito civil e o estado, dessa forma, seria tratado como um "cidadão regular". Assim como aconteceu ao longo da história fundiária do Brasil, o governo não seguiu suas próprias regras. Tampouco poderia fazê-lo, já que nem ao menos conseguia identificar onde estavam localizadas as terras devolutas.

${ }^{77}$ Holloway, Imigrantes, 176-7.

${ }^{78}$ Silva, Terras, 283-5.
} 
relatório datado de 1900, a não legalização das posses era o resultado direto da falta de credibilidade das instituições governamentais. ${ }^{79}$ Situações precedentes em questão de terras públicas haviam criado a ideia entre os posseiros de que a lei não seria executada e, uma vez vencido o prazo para registro, o esperado era ocorrerem sucessivas prorrogações. ${ }^{80}$

De fato, terminado o prazo para registro estabelecido na Lei n. 545 de 1898, quase nenhum posseiro realizou a legitimação das terras. $\mathrm{Na}$ teoria, as terras que não houvessem sido registradas cairiam automaticamente em comisso e passariam ao poder do estado. No entanto, caso o governo resolvesse aplicar a lei, as consequências para a economia seriam consideradas piores do que manter as posses em cultivo em poder dos posseiros. João Baptista de Mello Peixoto, secretário da Agricultura do governo de São Paulo em 1902, reconheceu que os interesses em jogo impediam a real aplicação da lei. ${ }^{81} \mathrm{O}$ prazo para registro das posses foi prorrogado mais duas vezes.

Sem um mecanismo de coação efetivo, como um imposto sobre as propriedades, multa ou mesmo a aplicação da cláusula que determinava o comisso das posses que não fossem legalizadas, os posseiros não buscaram registar suas terras. O próprio governo de São Paulo passou a perceber que o melhor a fazer seria legalizar as posses em cultivo, uma vez que despejar seus ocupantes estava fora de questão. ${ }^{82}$ Dessa forma, seriam reconhecidos os limites das invasões nas áreas inspecionadas pelos agentes do governo estadual e seria dado um fim ao limbo legal que se encontravam os posseiros. ${ }^{83}$

Em 1906, seguindo recomendações feitas por diversos secretários da Agricultura do governo de São Paulo em anos anteriores, definiu-se na Lei de Orçamento que seria dada preferência na venda de terras públicas aos posseiros que se encontrassem em morada habitual e cultura efetiva por um período de cinco anos, em uma extensão máxima de 500 hectares de floresta e 4.000 de pastagens. ${ }^{84}$ Ficava abandonado

\footnotetext{
${ }^{79}$ São Paulo, Relatório da Agricultura 1900, 98.

${ }^{80}$ Os diversos relatórios dos Secretários da Agricultura, em anos subsequentes, também mostram a não aplicação da lei. São Paulo, Relatório apesentado ao Dr. Domingos Correa de Matos, Vice-Presidente do Estado pelo Dr. Antonio Candido Rodrigues, Secretário da Agricultura, ano de 1901 (São Paulo: Typ. Diario Oficial, 1902), 71-2; São Paulo, Relatório apesentado ao Dr. Bernardino de Campos, Presidente do Estado pelo Dr. João Batista de Mello Peixoto, Secretário da Agricultura, ano de 1902 (São Paulo: Typ. Diario Oficial, 1903), 95-7; São Paulo, Relatório de 1903 pelo Dr. Luiz de T. Piza e Almeida, Secretário da Agricultura (São Paulo: Typ. Diario Oficial, 1904), 56-62.

${ }^{81}$ São Paulo, Relatório... Dr. João Batista de Mello Peixoto, 1902, 95-6.

82 São Paulo, Relatório... Dr. Luiz de T. Piza e Almeida, 111-2.

${ }^{83}$ Silva, Terras, 255-6.

${ }^{84}$ São Paulo, Relatório... Dr. Luiz de T. Piza e Almeida, 111-2.
} 
oficialmente o padrão utilizado até então, de anos fixos, como 1856 e 1895, para o registro das posses e passava a valer o tempo de ocupação, por um mínimo de cinco anos antes da inspeção oficial ou do pedido de validação. Essa medida, ao que tudo indica, parece ter sido posta em prática de forma proposital - seria melhor perder as terras, mas tê-las em cultivo na cafeicultura e, assim, recolher o imposto sobre o café exportado. Dessa forma, o governo estadual não impôs o cumprimento das leis que promulgava e foi parcial nas questões de terras.

Anos depois, uma nova discussão envolvendo terras devolutas aconteceu no Senado paulista com a apresentação do Projeto n. 6 de 1914, novamente de autoria de Luiz Piza, que autorizava o governo de São Paulo a incentivar o parcelamento de propriedade rural mediante auxílios indiretos. ${ }^{85}$ Piza, discursando no primeiro debate do projeto, sustentou que o parcelamento das grandes propriedades levaria à valorização das terras e ao povoamento do interior. O projeto de lei previa a concessão de empréstimos aos grandes proprietários que desejassem parcelar suas terras e vendê-las a pequenos agricultores. A venda dessas pequenas propriedades, no entanto, não estava destinada a qualquer cidadão. Para que o grande proprietário pudesse usufruir dos auxílios previstos no projeto, era preciso comprometer-se em vender os lotes a um preço mínimo de 2 e máximo de 8 contos de réis. Esse elevado valor, segundo Piza, serviria para garantir que todos os compradores fossem colonos com aptidão provada e na posse de economias razoáveis, que tivessem condições de pagar pelos lotes e ainda possuíssem reservas para o primeiro ano de seu estabelecimento. Assim, seria evitada a venda a "elementos fracos, que desacreditariam o seu princípio e os seus objetivos". ${ }^{86}$ Após discussões, o projeto foi remetido para receber parecer das Secretarias de Agricultura e Fazenda estaduais, o que aconteceu apenas em 1916. ${ }^{87}$ Apesar do parecer favorável, o projeto não voltou à discussão e foi rejeitado definitivamente em 1925 pelas Comissões de Agricultura e Fazenda, compostas pelos senadores Carlos Botelho, Fontes Jr., Azevedo Jr. e Candido Rodrigues. ${ }^{88}$

\footnotetext{
85 “Assembleia Legislativa," Senado sessão de 20/11/1914, Correio Paulistano, 22/11/1914, 2.

86 “Assembleia Legislativa," Senado sessão de 20/11/1914, Correio Paulistano, 22/11/1914, 2.

${ }^{87}$ São Paulo, Secretaria de Estado dos Negócio da Agricultura, Commercio e Obras Pública, Parecer $n$. 1572, de 17 de julho de 1916, Disponível em: https://www.al.sp.gov.br/repositorioAH/Acervo/Alesp/Documentos/046/0006_1914.pdf, Acesso em: 20 nov. 2018.

88 ALESP, Parecer n. 15 de 1925, Comissão de Agricultura e Fazenda, Disponível em: https://www.al.sp.gov.br/repositorioAH/Acervo/Alesp/Documentos/046/0006_1914.pdf Acesso em: 20 nov. 2018.
} 
Novas mudanças na legislação fundiária ocorreram apenas após a Primeira Guerra Mundial. A Lei n. 1844, promulgada em 27 de dezembro de 1921 e regulamentada em agosto de 1922, assim como sua predecessora, serviu para legalizar a situação de posseiros irregulares. ${ }^{89}$ Por essa nova lei, a terra poderia ser entregue gratuitamente a qualquer brasileiro nato ou naturalizado, desde que o posseiro reivindicasse a terra mais de um ano antes da data efetiva da lei; possuísse um título não válido anterior à lei; ou obtivesse a terra por decisão judicial. O governo, dessa forma, reconhecia todas as posses ocorridas entre 1895 e 1921 como legítimas.

Se as leis de terras aprovadas pelo congresso paulista visavam pouco mais que a regularização e legitimação das posses e pouco foi estabelecido especificamente no tocante ao acesso à terra pelos imigrantes, além de disposições gerais sobre a compra de terras devolutas, o mesmo não pode ser dito nas políticas específicas de colonização, como será visto a seguir.

\subsection{Os núcleos coloniais em São Paulo durante a Primeira República}

Durante a Primeira República, a política de núcleos coloniais voltou a ganhar espaço e diversos projetos foram propostos na Assembleia Legislativa de São Paulo visando fundar núcleos coloniais especificamente para o estabelecimento de imigrantes como pequenos proprietários. ${ }^{90}$ Alguns projetos propunham até mesmo a doação de terras devolutas a estrangeiros. Essas políticas serviam diretamente aos interesses das grandes propriedades, já que o objetivo do assentamento de imigrantes nos núcleos não seria modificar a estrutura fundiária vigente em São Paulo, mas fixar o imigrante à terra e ter uma oferta permanente de trabalho para as fazendas. Os fazendeiros, então, ficariam livres dos ônus com o colonato, pois não teriam que oferecer moradia e áreas de terra para que o imigrante plantasse gêneros de subsistência. Além disso, os custos

\footnotetext{
89 São Paulo, Lei n. 1844 de 27 de dezembro de 1921. Determina a forma da alienação de terras devolutas do Estado, Disponível em: https://www.al.sp.gov.br/repositorio/legislacao/lei/1921/lei-184427.12.1921.html, Acesso em: 20 nov. 2018.

${ }^{90}$ Para uma revisão bibliográfica sobre os núcleos coloniais em São Paulo, ver: Vera Lúcia Ferlini e Elizabeth Fillipini, “Os Núcleos Coloniais Paulistas em Perspectiva Historiográfica," Revista Brasileira de História 25 (1993). Sobre as políticas de colonização em São Paulo, ver o trabalho recente de Paulo César Gonçalves, Lélio Luiz de Oliveira e Pablo Oller Mont Serrath. "São Paulo e os sentidos da colonização." Revista História, Dossiê História da Colonização em Terras Paulistas: Dinâmicas e Transformações (Séculos XVI a XX) 39 (2020): 1-42.
} 
do Tesouro estadual com financiamento da imigração se reduziriam e as queixas constantes dos fazendeiros sobre a falta de mão de obra nas fazendas seriam atendidas. ${ }^{91}$

Pierre Denis, geógrafo e historiador francês, após longa viagem pela América Latina no começo do século XX, onde visitou as fazendas de café de São Paulo, afirmou que a vida no estado era tão relacionada com a cultura do café que a "nova política de colonização não teria tido chance de se tornar popular se os próprios fazendeiros não tivessem apoiado a ideia”. O temor de uma possível falta de braços na época das colheitas era tamanho que os fazendeiros passaram a aceitar a ideia de estabelecer colonos em pequenas propriedades a uma pequena distância das plantações de café, de modo a terem sempre "à mão um corpo de trabalhadores que necessariamente lhes seriam um público fiel a quem eles poderiam recorrer no momento necessário". ${ }^{92}$ Thomas Holloway chamou de racionalismo econômico esse pensamento que permitiu o surgimento destes núcleos coloniais já que não representavam risco aos interesses dos grandes cafeicultores paulistas. ${ }^{93}$

A imigração para a zona rural de São Paulo foi sempre marcada por grande instabilidade e pela mobilidade constante dos trabalhadores estrangeiros. A cada ano, ao final das colheitas, Pierre Denis estimou que entre $40 \%$ e $60 \%$ dos colonos deixavam as fazendas onde estavam localizados. ${ }^{94}$ Os imigrantes normalmente buscavam por novas áreas para se instalarem, com cafezais mais novos ou em fazendas com melhores oportunidades para o cultivo de subsistência, novas oportunidades na área urbana ou até mesmo em outros países, além de terem a opção de retornar ao país de origem. ${ }^{95}$ Visando fixar uma parcela dos imigrantes à terra, o governo estadual adquiriu terras marginais, despovoadas e não apropriadas para o cultivo do café, para a fundação de núcleos coloniais oficiais. A Secretaria da Agricultura de São Paulo mapeava as áreas, delimitando lotes grandes o suficiente para famílias de imigrantes, e nomeava um

\footnotetext{
91 São Paulo, Relatório... Antonio Candido Rodrigues 1901; São Paulo, Relatório... Carlos Botelho 1904;; Holloway, Imigrantes, 195-9; Regina M. d'Aquino Gadelha, "Os núcleos coloniais e o processo de acumulação cafeeira (1850-1920). Contribuição ao estudo da colonização em São Paulo" (Tese de Doutorado, FFLCH/USP, 1982).

92 Pierre Denis, Brazil (Londres: T. Fisher Unwin, 1911), 226.

${ }^{93}$ Holloway, Imigrantes, 194.

${ }^{94}$ Denis, Brazil.

95 Sobre as saídas das fazendas e a busca por cafezais mais novos, ver: Denis, Brazil; Vangelista, Os braços, 233-42; sobre o êxodo de imigrantes do campo para as cidades, ver: Hall, "Origins"; Verena Stolcke, Cafeicultura. Homens, Mulheres e Capital (1850-1980) (São Paulo: Editora Brasiliense, 1986); sobre a re-emigração para outros países, ver: André Luiz Lanza, "O fluxo migratório entre São Paulo e Buenos Aires: deslocamentos, nacionalidades e motivações (1890-1930)," HIb: Revista de Historia Iberoamericana 10, n. 1 (2017).
} 
administrador para supervisionar a colônia, receber os imigrantes e manter registro dos pagamentos dos lotes. Os núcleos coloniais seriam emancipados quando a maioria dos lotes estivesse quitada e os donos tivessem recebido os títulos de propriedade da terra, passando o núcleo a integrar o município em que estava localizado. ${ }^{96}$

Diversos projetos de lei autorizando o governo estadual a fundar núcleos coloniais foram propostos ao longo da Primeira República. Muitos, no entanto, foram rejeitados ou não tiveram efeito prático. ${ }^{97}$ As questões e problemas enfrentados no desenvolvimento dos núcleos no passado - localização distante das fazendas e centros urbanos, abandono dos lotes, falta de infraestrutura para acolhimento dos imigrantes levaram o governo a propor novos projetos visando a criação e regulação dos núcleos criados durante o período da imigração em massa para São Paulo. ${ }^{98}$

O deputado estadual Delfino Pinheiro de Ulhôa Cintra Júnior propôs, em 1889, o projeto n. 74, visando conceder auxílios às empresas que se organizassem para fundar núcleos e estabelecer imigrantes como proprietários de terra. ${ }^{99} \mathrm{Na}$ apresentação do projeto, Delfino Cintra argumentava que o problema da imigração em São Paulo envolvia tanto a introdução de imigrantes para a fazenda, algo que já vinha sendo resolvido por meio dos trabalhos da Sociedade Promotora, como o estabelecimento de imigrantes como proprietários, questão ainda em aberto. Segundo Cintra, essa parte do problema não representava o interesse da classe dos grandes cafeicultores, mas estava ligada ao futuro de São Paulo, com a organização da pequena fazenda e da variedade de culturas. O imigrante que não aceitasse o regime de trabalho na fazenda e que preferisse tornar-se proprietário, ou o colono que já tivesse acumulado pecúlio e desejasse adquirir sua propriedade, reemigraria para outros lugares se não encontrasse vantagens em São Paulo, afirmava o deputado. A fundação de núcleos coloniais serviria para atrair novos imigrantes, fixar os existentes à terra e ser repositório para o excedente de colonos para as fazendas, como viveiros de trabalhadores. ${ }^{100}$

\footnotetext{
${ }^{96}$ Holloway, Imigrantes, 195-6.

${ }^{97}$ Um exemplo foi o Projeto n. 7 de 1895, proposto na Câmara e rejeitado pelo Senado, por constar na lei de orçamento vigente à época a previsão de gastos com fundação de núcleos coloniais; o substitutivo a esse mesmo projeto, foi aprovado em 1899 pelo Senado, mas rejeitado em 1907 pela comissão de Obras Públicas e Fazenda sob justificativa de ter perdido sua oportunidade de aplicação e por estar o tema regido por nova lei.

98 "Colônia do Pariquerá," O Correio Paulistano, 27/05/1887, 2.

99 São Paulo, Annaes da Assembleia Legislativa Provincial de São Paulo (AALPSP), sessão de 14/02/1889, 161, 476-8.

${ }^{100}$ AALPSP, sessão de 14/02/1889, 161.
} 
Em 1895, o secretário da Agricultura de São Paulo, Theodoro Dias de Carvalho Jr., retomou o tema solicitando que fosse incentivada a formação de núcleos coloniais pela iniciativa privada para que os imigrantes se fixassem à terra e o estado não tivesse que se encarregar de manter as colônias oficiais. A ideia seria que as terras nos centros cafeeiros que não fossem apropriadas para o cultivo do café poderiam ser divididas pelos seus proprietários. As vantagens aos grandes proprietários seriam a de receber por uma terra que não tinha grande valor econômico e ter ao seu redor núcleos coloniais que serviriam de reserva de braços para a fazenda. ${ }^{101}$ Anos depois, o presidente do estado, Francisco de Paula Rodrigues Alves, adotaria posição semelhante, afirmando que era preciso fixar os imigrantes, mas de modo que estivessem ao alcance da grande fazenda quando esta precisasse de seu trabalho, fazendo $\mathrm{cm}$ que os núcleos fundados fossem verdadeiros viveiros de trabalhadores agrícolas. ${ }^{102}$

Em 1898, Arnolpho Azevedo, deputado estadual pelo Partido Republicano Paulista, defendeu o papel do governo do estado na criação de núcleos coloniais voltados à pequena propriedade em discussão sobre o Projeto n. 7, de 1895, por ele mesmo proposto, autorizando o executivo a realizar operações de crédito para a criação e custeio de núcleos coloniais em diversos municípios do estado. ${ }^{103}$ Para o deputado, não seria possível esperar que os grandes proprietários criassem tais núcleos, visto que não lhes seria rentável investir em pequenas fazendas de cereais ou partilhar seus terrenos diante do lucro que obtinham com a cultura cafeeira. Tampouco poderia se esperar que o governo de São Paulo simplesmente retalhasse suas terras devolutas e as ofertasse gratuitamente, já que a maioria dessas terras estava localizada longe dos centros consumidores e das redes de transporte. Dessa forma, ao estado restaria dividir a terra e ofertá-la por meio da venda a pequenos lavradores. ${ }^{104}$

A pequena propriedade, para Arnolpho Azevedo, teria o papel de abastecer o mercado interno paulista com gêneros alimentícios, suprido então, segundo ele, por meio de importações de outros estados. Azevedo afirmava ainda que os imigrantes

\footnotetext{
${ }^{101}$ São Paulo, Relatório apresentado ao cidadão Dr. Presidente do Estado pelo Dr. Theodoro Dias de Carvalho Junior, ano de 1895 (São Paulo: Typ. A Vap.- Espindola, Siqueira \& Comp., 1896), 35-7.

${ }^{102}$ São Paulo, Boletim da Agricultura 2a série, n. 1, anno de 1901 (São Paulo: Red. da Revista Agrícola, 1901), 691.

103 Câmara dos Deputados de São Paulo. Projecto n. 7 de 1895 Disponível em: https://www.al.sp.gov.br/repositorioAH/Acervo/Alesp/Documentos/C_lt017/0007_1895.pdf. Acesso em: 27 nov. 2018.

104 “Assembleia Legislativa," Câmara dos Deputados, sessão de 01/06/1898, Correio Paulistano, 02/06/1898, 1 .
} 
localizados nas fazendas como colonos, por mais que conseguissem acumular pecúlio, não teriam onde aplicá-los, já que não havia terras disponíveis para venda. ${ }^{105} \mathrm{O}$ cultivo de subsistência dentro das fazendas seria muito limitado em comparação ao que os colonos poderiam produzir e ganhar como pequenos proprietários. Suas ideias encontraram opositores, como Alfredo Gurde, Rubião Jr. e Rangel Jr., defensores das grandes propriedades e das oportunidades que esta oferecia aos colonos, mas encontraram também diversos apoiadores, que compartilhavam do mesmo pensamento e defendiam o povoamento por meio dos núcleos coloniais. ${ }^{106}$

Augusto César Miranda de Azevedo, em outra sessão, continuando a discussão do projeto proposto por Arnolpho Azevedo, sustentou que os núcleos trariam resultados positivos para a produção agrícola de São Paulo, apesar dos problemas com administração e organização que enfrentavam. Miranda de Azevedo deparou-se com a oposição de colegas que não desejavam o aumento das despesas do governo com o serviço da imigração e colonização ou que afirmavam que os colonos encontravam-se em melhor posição que os agricultores dos núcleos. ${ }^{107}$ Afirmava o deputado que, apesar de não ser um grande proprietário, não deixava de considerar que a base da prosperidade do estado se encontrava na grande fazenda. No entanto, fazia-se necessário desenvolver a pequena propriedade ao mesmo tempo em que se auxiliava a grande, já que não podia o estado de São Paulo depender exclusivamente do café. Seguindo a mesma ideia de muitos colegas, o deputado também afirmava que os núcleos coloniais facilitariam a captação de mão de obra pelos grandes proprietários no período das colheitas a um custo muito mais baixo e resolveriam o problema da fixação do imigrante na terra. Miranda de Azevedo propôs, inclusive, que o governo concedesse lotes gratuitos dos terrenos devolutos a famílias de agricultores. ${ }^{108}$

O senador Ezequiel Ramos propôs, em um projeto em substituição ao de Arnolpho Azevedo que estava em debate no Senado paulista, a mesma ideia de doação de terras devolutas apresentada por Miranda Azevedo, apesar de ser contra a implementação do sistema de núcleos coloniais em São Paulo por julgar que estes não

\footnotetext{
105 “Assembleia Legislativa," Câmara dos Deputados, sessão de 01/06/1898, Correio Paulistano, 02/06/1898, 2.

106 "Assembleia Legislativa," Câmara dos Deputados, sessão de 01/06/1898, Correio Paulistano, 02/06/1898, 2.

107 "Assembleia Legislativa," Câmara dos Deputados, sessão de 06/06/1898, Correio Paulistano, 07/06/1898, 1-2.

108 “Assembleia Legislativa," Câmara dos Deputados, sessão de 06/06/1898, Correio Paulistano, 07/06/1898, 2.
} 
progrediam, citando como exemplo os núcleos de Cannas e Cascalho, criados pela Lei n. 28 de março de 1884. Segundo Ezequiel Ramos, tais núcleos encontravam-se em decadência em 1898, com declínio populacional e predominância de nacionais entre os habitantes. Julgava o senador, dessa forma, ser incoerente o estado gastar avultadas somas com a colonização de nacionais, visto que a lei de terras paulista previa a alienação de terras devolutas por meio da compra e que isto por si só já bastaria para tornar o nacional pequeno proprietário. $\mathrm{O}$ senador propunha que o estado apenas demarcasse e vendesse as terras devolutas, sem a necessidade de criar núcleos coloniais. Concluindo sua exposição, Ezequiel Ramos propôs um novo projeto que englobasse todas as necessidades de povoamento do estado, a ideia da pequena propriedade e da localização dos imigrantes na terra. No projeto, ficava prevista a doação gratuita de terras, em uma extensão máxima de 50 hectares, aos imigrantes que chegassem ao estado por conta própria. O estado se encarregaria dos custos com medição e demarcação dos terrenos. ${ }^{109} \mathrm{O}$ projeto proposto por Ezequiel Ramos acabou rejeitado pelo Senado estadual. ${ }^{110}$

Antônio Candido Rodrigues apoiou a proposição de Miranda de Azevedo e, no parecer da Comissão de Obras Públicas e Fazenda, afirmou que ligar o colono à terra que cultivava era ligá-lo ao país para o qual emigrava, proporcionando-lhe uma nova pátria. Apesar dos núcleos existentes não darem na opinião do deputado os resultados esperados, Candido Rodrigues argumentou que a localização de novos núcleos às margens das estradas de ferro ou rios navegáveis e às portas dos mercados consumidores poderia levar à prosperidade esperada. $\mathrm{O}$ deputado também chamava a atenção para a vantagem de ter os imigrantes assentados em núcleos próximos às fazendas, para servirem de mão de obra na época das colheitas. ${ }^{111} \mathrm{O}$ projeto foi aprovado em 1899, mas acabou rejeitado em 1907 pela comissão de Obras Públicas e Fazenda, sob a justificativa de ter perdido sua oportunidade de aplicação em vista de novas leis aprovadas regendo o tema da fundação de núcleos coloniais. ${ }^{112}$

\footnotetext{
109 “Assembleia Legislativa,” Senado, sessão de 01/06/1899, Correio Paulistano, 02/06/1899, 2. 110 “Assembleia Legislativa," Senado, sessão de 11/09/1899, Correio Paulistano, 12/11/1899, 2. 111 ALESP, Parecer n. 60 da Comissão de Obras Públicas e Fazenda, 19 de junho 1899. Disponível em: https://www.al.sp.gov.br/repositorioAH/Acervo/Alesp/Documentos/115/0007_1895.pdf.. Acesso em: 12 nov. 2018.

112 ALESP, Parecer n. 16 de 1907 das Comissões de Obras e Justiça, 19 de julho de 1907. Disponível em: https://www.al.sp.gov.br/repositorioAH/Acervo/Alesp/Documentos/115/0007_1895.pdf. Acesso em: 12 nov. 2018.
} 
No começo do século $\mathrm{XX}$, outros dois projetos relacionados aos imigrantes foram propostos no legislativo de São Paulo. Diferentemente dos anteriores, estes não visavam a criação de núcleos coloniais, mas sim ao próprio estabelecimento de imigrantes como proprietários. Em sessão de 30 de abril de 1901, o senador Jorge Tibiriçá propunha que o governo de São Paulo despendesse até 600 contos de réis na compra e parcelamento de terrenos de primeira qualidade, a fim de destiná-los especialmente aos estrangeiros que já se encontrassem no estado e que houvessem acumulado pecúlio pelo trabalho nas fazendas. Tibiriçá, seguindo a linha dos que defendiam a criação dos núcleos coloniais, afirmava que seu projeto visava remediar um mal que vinha acometendo o estado naqueles anos: o êxodo de imigrantes que, após terem conseguido fazer alguma economia, buscavam a re-emigração ou o repatriamento. $\mathrm{O}$ projeto definia também que a venda deveria ser feita à vista e, apenas em circunstâncias especiais, o governo poderia abrir exceção e conceder um prazo extra para os que pagassem ao menos $70 \%$ do valor do terreno. Tal medida visava evitar a compra especulativa e atrair apenas aqueles ex-colonos que já estavam habituados ao trabalho nas fazendas do estado e que veriam nessa empreitada a chance de tornarem-se proprietários em São Paulo. ${ }^{113}$ À época da proposta desse projeto, a Lei n. 545 de 1898, segunda lei de terras paulista, ainda não estava em vigor. É interessante notar como Tibiriçá já julgava não haver terras devolutas nos locais atrativos para os imigrantes, ou seja, onde havia ligação com ferrovias e centros urbanos. Nesse sentido, na opinião do senador, seria melhor o governo comprar terras e depois revendê-las.

O projeto apresentado por Jorge Tibiriçá chegou inclusive a receber parecer favorável pelos senadores Peixoto Gomide, Bento Bicudo e Ferraz de Salles, membros da Comissão de Imigração e Colonização do Senado paulista, que o julgaram uma boa forma de facilitar o povoamento do estado e incorrer em menores encargos do que com os núcleos coloniais. ${ }^{114}$

Ezequiel Ramos, em face do projeto proposto por Tibiriçá, apresentou em maio de 1901 uma alternativa ainda mais arrojado que previa a doação pura e simples de 50 hectares de terras devolutas a todos os imigrantes agricultores que se dispusessem a se

\footnotetext{
${ }^{113}$ Projeto e debates no Senado Transcrito em Gherardo Pio di Savoia, "Lo stato di San Paolo (Brasile) e l'emigrazione italiana," in Bolletino dell'emigrazione anno 1905, ed. Ministerio degli Affari Esteri (Roma: Tipografia nacionalide di G. Bertero, 1906), 225-31; ALESP, Projeto n. 3, de 1901, do Senado, Disponível em: https://www.al.sp.gov.br/repositorioAH/Acervo/Alesp/Documentos/136/0003_1901.pdf. Acesso em: 29 jan. 2019.

114 ALESP, Projeto n. 3.
} 
estabelecer por conta própria em São Paulo. Esse projeto previa que todos os encargos de medição ficariam sob responsabilidade do governo de São Paulo e que o imigrante perderia a posse da terra caso não a cultivasse no prazo de um ano. $\mathrm{O}$ projeto enfrentou resistência dos outros senadores, que questionavam quais seriam e onde estariam localizadas as terras devolutas das quais falava o senador Ramos. ${ }^{115}$ Tanto o projeto de Jorge Tibiriçá quanto o de Ezequiel Ramos não entraram mais em pauta e acabaram arquivados definitivamente em 1907. ${ }^{116}$ Nota-se, pelo exposto até aqui, que a maioria dos projetos e discussões sobre os núcleos coloniais e os usos das terras devolutas para estabelecimento de imigrantes ou não tinham andamento ou eram rejeitados.

A fundação de núcleos coloniais em São Paulo ganhou força após Carlos José Arruda Botelho assumir a Secretaria da Agricultura do estado em 1904. Botelho defendia a criação de núcleos próximos às estradas de ferro e em regiões menos adequadas para o cultivo do café, mas boas para as culturas de alimentos. ${ }^{117}$ Botelho era partidário de parcerias com a iniciativa privada para a fundação dos núcleos. Em 1905, firmou contrato com a Companhia "Pequena Propriedade" para a criação do núcleo Dr. Jorge Tibiriçá, em terras da antiga fazenda São José do Corumbataí. ${ }^{118}$ No mesmo ano, o governo adquiriu terras da fazenda Pombal para fundação do núcleo Nova Odessa para localização exclusivamente de imigrantes russos, assim como aumentou a extensão do núcleo Campos Salles.

Entre 1905 e 1911 foram fundados onze núcleos coloniais no estado de São Paulo, a maior parte em terras de fazendas e em regiões cafeeiras. Os núcleos criados, pela proximidade com as fazendas de café, tinham o objetivo de formar os viveiros de trabalhadores para a grande fazenda. ${ }^{119}$ A Tabela 1.1 traz os núcleos coloniais fundados enquanto Carlos Botelho esteve à frente da Secretaria da Agricultura.

\footnotetext{
${ }^{115}$ Questionamentos feitos por Paulo Egydio: “A questão é precisamente saber se existem precisamente essas terras devolvidas de que fala". E Jorge Tibirçá: "onde estão as terras devolvidas mencionadas pelo autor do contraprojeto?" Peixoto Gomide (membro da comissão do Senado para imigração e colonização): "Basta dizer que nem mesmo sabemos que temos, com certeza. Um processo de discriminação muito diligente é necessário primeiro". Pio di Savoia, "Lo stato," 230-1.

116 ALESP, Projeto n. 3; ALESP, Projeto n. 3-A, de 1901, do Senado, disponível em: https://www.al.sp.gov.br/repositorioAH/Acervo/Alesp/Documentos/136/003A_1901.pdf. Acesso em: 29 jan. 2019.

${ }_{117}$ São Paulo, Relatório... Dr. Carlos Botelho ano de 1904, 132.

${ }^{118}$ São Paulo, Relatório... Dr. Carlos Botelho ano de 1905, 126-40.

119 Pierre Monbeig, Pioneiros e fazendeiros de São Paulo (São Paulo: HUCITEC, 1984), 160; Paula Beiguelman, Formação do Povo no Complexo Cafeeiro: aspectos políticos (São Paulo: Pioneira, 1975), 59. Gadelha, "Os núcleos," 240.
} 
Tabela 1.1 - Núcleos coloniais fundados em São Paulo entre 1905 e 1911

\begin{tabular}{ccc}
\hline Núcleo & Localização & Fundação \\
\hline Bandeirantes & S. J. do Barreiro & 1908 \\
Conde do Pinhal & Ubatuba & 1905 \\
Conde de Parnaíba & Campinas & 1911 \\
Gavião Peixoto e seção Nova Pauliceia & Araraquara & 1908 \\
Jorge Tibiriçá & Rio Claro & 1906 \\
Martinho Prado Junior & Rio Claro & 1911 \\
Monção & Avaré & 1910 \\
Nova Europa & Ibitinga & 1907 \\
Nova Odessa & Campinas & 1904 \\
Nova Veneza & Campinas & 1910 \\
Visconde de Indaiatuba & Mogi Mirim & 1911 \\
\hline
\end{tabular}

Fonte: São Paulo, Relatórios da Secretaria da Agricultura, vários anos.

Em plena crise cafeeira, o governo estadual decretou em 27 de dezembro de 1906 a Lei n. 1045-C, a primeira norma legal sistemática sobre imigração e colonização do estado, regulamentada por sua vez pelo Decreto n. 1.458 de 10 de abril de $1907 .{ }^{120} \mathrm{~A}$ lei, iniciativa do presidente do estado Jorge Tibiriçá, visou reunir em uma única peça legislativa todas as medidas e providências relativas ao tema que se encontravam espalhadas em diversos projetos de lei, leis aprovadas, resoluções e decretos do executivo paulista. ${ }^{121}$ Seu objetivo era organizar todo o sistema de imigração do estado de São Paulo e dar amparo aos imigrante, garantindo seu transporte desde o país de origem, desembarque em Santos, alojamento na Hospedaria do Imigrante, colocação e transferência para as fazendas de destino.

A lei e seu regulamento buscaram abranger também todos os aspectos relativos à fixação do imigrante no estado e traziam artigos específicos sobre a venda de lotes de terra, condições de pagamento e as ajudas oficiais que poderiam ser ofertadas para facilitar a colocação do estrangeiro como proprietário rural. ${ }^{122}$ Era prevista a colonização oficial e fundação de núcleos coloniais tanto pelo próprio governo estadual quanto pelas câmaras municipais, por meio de empresas, particulares ou pelas

\footnotetext{
${ }^{120}$ São Paulo, Lei n. 1045-C de 27 de dezembro de 1906, dispõe sobre a imigração e colonização no território do Estado, Disponível em: https://www.al.sp.gov.br/repositorio/legislacao/lei/1906/lei-1045C27.12.1906.html, Acesso em: 05/12/2018; São Paulo, Decreto n. 1.458, de 10 de abril de 1907, Dá regulamento para execução da Lei $n .1045$ C, de 27 de Dezembro de 1906, que dispõe sobre a immigração e colonização no territorio do Estado, Disponível em: https://www.al.sp.gov.br/repositorio/legislacao/decreto/1907/decreto-1458-10.04.1907.html, Acesso em: $05 / 12 / 2018$

121 “Assembleia Legislativa," Senado, sessão de 15/12/1906, Correio Paulistano, 16/12/1906, 1-2.

${ }^{122}$ São Paulo. Lei n 1045-C; São Paulo, Decreto n. 1.458, Art. 139-159.
} 
companhias de estradas de ferro. Nos núcleos coloniais oficiais do estado, estabelecia-se a venda a prazo de lotes de terras demarcados e medidos para os estrangeiros, prevendo, inclusive, a prorrogação dos prazos para pagamento se a terra se encontrasse em cultivo e com morada habitual. Haveria núcleos específicos para os imigrantes recém-chegados, com infraestrutura para que pudessem se habituar com o país e a cultura. Para a iniciativa particular que visasse fundar núcleos em suas próprias terras, o governo previa a restituição dos gastos com as passagens dos imigrantes e demais favores previstos na lei, além da soma de dez contos de réis para cada grupo de 50 famílias localizadas nos núcleos. Nas inciativas que contassem com a doação de terras devolutas, o governo arcaria com metade dos custos de medição e demarcação e ficaria com metade dos lotes. ${ }^{123}$

Em 1911, sob o comando de Paulo de Morais Barros, a política de núcleos coloniais que vinha sendo posta em prática na Secretaria da Agricultura sofreu mudanças. Diferente de seus antecessores, para o secretário da Agricultura o estado deveria resumir-se à divisão da terra em pequenos lotes e à venda dos mesmos a particulares. Morais Barros era crítico da atuação estatal na fundação de núcleos coloniais, por considerá-los onerosos aos cofres públicos e não garantir o povoamento do estado. Em 1913, o então secretário da Agricultura recomendava que não fossem abertos novos núcleos no estado, visto que a maioria dos que ocupavam os lotes não eram imigrantes. Em visão contrária ao que vinha sendo defendido por deputados, senadores e antigos secretários da Agricultura, para ele apenas após o fornecimento de braços para a fazenda é que o governo deveria se preocupar em atrair imigrantes para a pequena propriedade. A formação de pecúlio através do trabalho nas fazendas seria o caminho para a aquisição de terras. ${ }^{124}$

A Lei n. 1045-C foi modificada em 1914 pela Lei n. 1.457, de 29 de dezembro, estendendo a todos os pretendentes, nacionais e estrangeiros já estabelecidos no país, a possibilidade de aquisição de terrenos em núcleos coloniais no estado de São Paulo, facilitando, assim, o acesso à terra. ${ }^{125} \mathrm{O}$ projeto de lei, apresentado pelo vice-presidente

\footnotetext{
123 São Paulo. Lei n 1045-C.

${ }^{124}$ São Paulo, Relatório da Agricultura 1912-1913, 208.

125 São Paulo, Lei $n 1457$ de 29 de dezembro de 1914, Modifica a Lei n. 1045-C, de 27 de Dezembro de 1906, que dispõe sobre a imigração e colonização no território do Estado. Disponível em: https://www.al.sp.gov.br/repositorio/legislacao/lei/1914/lei-1457-29.12.1914.html. Acesso em: $18 \mathrm{dez}$. 2018. "Artigo 30. - Às familias da immigrantes que não dispuzerem de recursos para o pagamento immediato da primeira prestação, mas tiverem, pelo menos tres pessoas maiores de. 12 annos, aptas para o trabalho, poderá o Governo, excepcionalmente conceder que, pelo prazo de um anno, residam e
} 
do estado, visava facilitar o estabelecimento de famílias de agricultores sem recursos que buscavam colocação no estado. Dessa forma, segundo o texto da lei, a produção de gêneros de primeira necessidade seria impulsionada e o imigrante se fixaria ao solo. A ideia encontrou amplo apoio na Assembleia Legislativa. O deputado Antônio Mercado sugeriu que a medida englobasse os nacionais também, visto que não considerava justo dar preferência a estrangeiros que já se encontrassem estabelecidos como colonos nas fazendas do estado, o que foi acatado pela Câmara. O parecer emitido pelos senadores Guimarães Junior e Fernando Prestes, da Comissão de Colonização, Terras Públicas e Minas do Senado, destacava que o projeto significava um "seguro incentivo para a fixação no solo" de São Paulo para todo o trabalhador que após conseguir acumular algumas reservas desejasse tornar-se proprietário rural, "afastando de seu espírito a ideia de procurar essas vantagens em outras partes onde leis mais liberais lhe permitam a realização daquele sonho tão justo e tão longamente esperado". ${ }^{126}$

Quando se analisa a situação dos núcleos coloniais oficiais por meio de sua representatividade na agricultura paulista como fonte de mão de obra para a fazenda, ou entre as propriedades dos imigrantes, parece que as queixas dos secretários que assumiram a pasta da agricultura após Carlos Botelho faziam algum sentido. Já em 1935 Caio Prado $\mathrm{Jr}$ afirmava que se fossem computados todos os lotes colonizados oficialmente no estado, não seriam encontrados mais que 3 ou 4 mil propriedades. ${ }^{127}$ Naquele ano, existiam 248.760 propriedades rurais em São Paulo. ${ }^{128} \mathrm{O}$ boletim do Departamento Estadual do Trabalho de 1917 revela que as fazendas situadas próximas aos núcleos tinham menos problemas em conseguir mão de obra na época das colheitas, e, ainda assim, não tiravam o proveito que poderiam dessa facilidade. Se os núcleos não estavam servindo ao propósito de fornecer mão de obra, a causa era a preferência dos fazendeiros pelos imigrantes recém-chegados ou o progresso que os pequenos

cultivem um lote, com a condição de, no fim desse prazo, pagarem o aluguel que houver sido estipulado pelas terras, ou entrarem com o preço preciso para receberem o título provisório das mesmas". São Paulo. Lei $1045-C$.

126 ALESP, Parecer n. 53 da Commissão de Colonização, Terras Públicas e Minas do Senado 25 de novembro de 1914, Disponível em: https://www.al.sp.gov.br/repositorioAH/Acervo/Alesp/Documentos/CX_117/0022_1914.pdf, Acesso em: $18 / 12 / 2018$.

127 Nas palavras do autor "Se (os núcleos coloniais) existiram, foi só para servir de isca às correntes imigratórias que não nos procuravam na medida exigida pelos interesses da grande lavoura de café". Caio Prado Jr, "Distribuição da propriedade fundiária rural no estado de São Paulo" [Publicado originalmente em Geografia 1, v. 1, 1935], Boletim Geográfico 29 (out. 1945): 696-7.

${ }^{128}$ São Paulo, Secretaria da Agricultura, Industria e Commercio, Estatistica Agrícola e Zootechnica 19341935 (São Paulo: Directoria de estatística, indústria e commercio, 1936), 20. 
proprietários haviam obtido com sua produção. ${ }^{129}$ Sobre essas afirmações trazidas pelo boletim, aparentemente a primeira estava correta, pois havia grande demanda de imigrantes recém-chegados pelas fazendas. O fluxo de imigrantes para as fazendas continuou sendo prioridade do governo de São Paulo, tendo o sistema de subsídios sobrevivido até 1928. A segunda assertiva, sobre o sucesso dos pequenos proprietários dos núcleos coloniais, merece uma análise mais detalhada.

Em 1918, a população total dos núcleos era de 20.763 pessoas, sendo que os brasileiros somavam 12.699, frente a 8.064 estrangeiros. Apenas 9.771 possuíam 14 anos ou mais, permitindo supor com isso que os núcleos não constituíam a reserva de braços para a fazenda que se esperava. Nesse mesmo ano, a área total de terra dos núcleos - 106.000 hectares - representava $0,9 \%$ do das terras privadas de São Paulo. As terras em cultivo eram apenas 29.000 hectares, 1,4\% do total da área cultivada do estado. Apenas três das onze colônias oficiais ainda sob tutela do estado naquele ano possuíam mais estrangeiros do que nacionais ocupando seus lotes. É possível, então, que a política de colonização oficial não estivesse obtendo sucesso em fixar o imigrante estrangeiro e, menos ainda, em servir de "viveiros de trabalhadores" para as fazendas. ${ }^{130}$ No anexo A1.1 apresenta-se a situação de cada núcleo oficial existente no período de 1911 a 1918.

Os últimos núcleos que se encontravam sob jurisdição do governo foram emancipados em 1923. Neste ano, o secretário da Agricultura do governo de São Paulo informou que os núcleos não estavam sendo povoados por imigrantes, mas quase exclusivamente por colonos que já haviam adquirido experiência e pecúlio nas grandes fazendas. Segundo o relatório do secretário da Agricultura apresentado naquele ano, as próprias fazendas sofriam com o êxodo de trabalhadores que já haviam acumulado capital suficiente para se tornarem donos de suas próprias terras. ${ }^{131}$

\footnotetext{
${ }^{129}$ São Paulo, Secretara da Agricultura, Commercio e Obras Públicas, Boletim do Departamento Estadual do Trabalho 5, n. 23 ( $2^{\circ}$ trim. 1917), 278.

${ }^{130} \mathrm{O}$ que está sendo levado em consideração aqui é o resultado da política de núcleos coloniais no tocante ao acesso à terra pelos estrangeiros e sua importância no quadro geral dos estrangeiros como proprietários de terra em São Paulo. Estudo recente mostra que, no longo prazo, regiões que tiveram a presença de núcleos coloniais apresentam índices mais altos de alfabetização e renda per capita. Rudi Rocha, Claudio Ferraz, Rodrigo Soares, "Human Capital Persistence and Development," American Economic Journal: Applied Economics 9, n. 4 (2017): 105-36.

${ }^{131}$ São Paulo, Relatório da Agricultura de 1923 apresentado ao Presidente do Estado pelo Dr. Heitor Teixeira Penteado, Secretário da Agricultura (São Paulo, 1924), 127-9.
} 
Pelo que se constata dos debates legislativos e as leis aprovadas, o que o governo estadual e os fazendeiros desejavam com os núcleos coloniais não era a pequena propriedade em si, mas antes uma simbiose das grandes propriedades com pequenos sítios, em uma relação em que estes últimos servissem para atender às necessidades das fazendas cafeeiras. O programa oficial de núcleos coloniais do estado de São Paulo serviu mais como forma de propaganda, como atrativo para os que planejavam deixar seus países em busca de uma vida melhor no outro lado do Atlântico, em vez de uma possível forma de alternativa ao trabalho enquanto colonos nas fazendas. Ainda assim, apesar da política relativa aos núcleos oficiais, os imigrantes alcançaram significativa representatividade no quadro dos proprietários rurais de São Paulo, como será visto nos próximos capítulos.

\section{Conclusões}

Através de debates parlamentares e opiniões de políticos e intelectuais, este capítulo examinou as ideias discutidas durante o Império e durante as primeiras décadas de República sobre o acesso à terra pelos imigrantes em São Paulo. Em meio à enorme expansão cafeeira nesse período pressão para a legalização de terras e por mão de obra para as fazendas se intensificou continuamente. Atrair mão de obra imigrante era uma prioridade, especialmente após a abolição da escravatura.

Dadas a concentração da propriedade da terra e a influência política dos grandes proprietários, era de se esperar que a legislação e as políticas fundiárias propostas visassem preservar o status quo e impedir o acesso de brasileiros e estrangeiros pobres à propriedade rural. De fato, a política que prevaleceu foi a de imigrantes prioritariamente destinados às fazendas, não para tornarem-se proprietários de terras assim que chegassem a São Paulo. No entanto, o que se nota ao se analisar os debates travados na Assembleia Legislativa de São Paulo, os jornais da época, os discursos dos governantes é que houve por parte de diferentes grupos também vozes relativamente dissonantes que defenderam o acesso à pequena propriedade pelos estrangeiros. De qualquer maneira, sempre esse acesso à terra por imigrantes deveria ocorrer em simbiose com os interesses do café.

As leis de terras aprovadas pela Assembleia Legislativa do estado de São Paulo pouco ou nada trouxeram em relação ao acesso do imigrante à terra. A primeira lei de terras aprovada no estado em 1893 foi considerada excessivamente rigorosa, por utilizar 
os prazos estabelecidos na Lei de Terras de 1850 como referência para a legitimação dos posseiros. A lei determinava que todas as terras que não estivessem em domínio particular por título legítimo até a data estabelecida pela Lei de terras de 1850 e seu regulamento de 1854 seriam consideradas devolutas. A lei tentou também limitar o tamanho das novas propriedades por meio da área dos lotes a serem vendidos, do tamanho das posses a serem legitimadas, e por meio da reserva de terras devolutas do estado para a fundação de núcleos coloniais. Poucos anos depois, a primeira lei foi substituída por outra mais permissiva com relação aos posseiros: todas as posses realizadas entre 1854 e 1895 tornaram-se passíveis de legitimação. A nova lei não trouxe qualquer menção à reserva de terras para núcleos coloniais ou à promoção da imigração por meio do acesso à terra. Mesmo com as facilidades dadas aos posseiros, o que se viu foi uma continuação dos problemas vividos com a Lei de Terras de 1850: a falta de interesse dos particulares em regularizar suas posses, a percepção de que a lei não seria aplicada, a constante prorrogação de prazo e a incapacidade geral de enforcement por parte do governo.

Os projetos de lei propostos no período que versavam sobre a doação pura e simples de terra aos estrangeiros (e brasileiros) ou que previam de alguma maneira a alienação da terra como forma de criar uma corrente permanente de imigração não passaram no parlamento. O imigrante deveria vir comprometido com o trabalho da grande propriedade; a aquisição de uma propriedade rural viria com o tempo.

O acesso à terra para os imigrantes em São Paulo enquanto política pública sistemática e mais coerente consolidou-se apenas a partir do começo do século XX e somente porque a venda de lotes de terras e estabelecimento de imigrantes em núcleos coloniais tornou-se complementar aos interesses da elite cafeeira. A partir de 1910, o governo estadual passou a incentivar o parcelamento e venda a baixo preço de lotes de antigas fazendas em decadência. A tradicional elite cafeeira beneficiava-se porque preservava as melhores terras para o cultivo do café, ofertava aos estrangeiros aquelas que já não eram propícias para a agricultura de exportação e mantinha os colonos próximos às suas fazendas, reforçando a enorme oferta de mão de obra que se concretizou com a grande imigração. 


\section{CAPÍTULO 2 - OS REGISTROS DE MATRÍCULA DA HOSPEDARIA DE IMIGRANTES EM SÃO PAULO, 1886-1920}

O movimento abolicionista intensificou, durante a década de 1880 , o temor da falta de braços que já vinha se formando na agricultura paulista pelo menos desde 1850 . As experiências com trabalho livre levadas a cabo até então ficavam aquém da demanda crescente de mão de obra para a cafeicultura em expansão. De 1826, data em que foi introduzida a primeira leva de imigrantes com auxílios governamentais, até 1884 chegaram a São Paulo pouco menos de 45.000 estrangeiros. ${ }^{1}$ As políticas adotadas até então para se estabelecer um fluxo espontâneo de imigração não surtiram efeito. Como visto anteriormente, ao longo dos anos 1880 o governo de São Paulo buscou promover, organizar e distribuir a imigração na província, por meio de um sistema de subsídios que se consolidou a partir de meados da década. As leis promulgadas e a criação da Sociedade Promotora de Imigração deram forma ao programa de introdução de imigrantes, organizando um sistema de subsídios de passagens, determinando o tipo de imigrante a quem o subsídio se destinava e atraindo empresas e particulares para participar desse processo. Foram investidas vultosas somas na compra de um terreno e na construção de uma Hospedaria, com capacidade para receber 3.000 imigrantes, localizada no bairro do Brás, na capital São Paulo. A Hospedaria de Imigrantes foi concluída em 1888 e substituiu a que estava em funcionamento desde 1882 no Bom Retiro, que se tornara pequena diante da entrada de estrangeiros em São Paulo. ${ }^{2}$

De 1884 até 1920, quase 1,8 milhão de imigrantes destinaram-se a São Paulo, em sua grande maioria para o trabalho nas fazendas do interior. Desses estrangeiros, mais da metade recebeu auxílio do governo de São Paulo, com a maior parte das entradas concentrando-se na década de 1890. Ao desembarcarem no porto de Santos, os imigrantes passavam por uma primeira vistoria pela Inspetoria de Imigração do Porto e então eram conduzidos pela ferrovia até a capital São Paulo, onde davam entrada na Hospedaria de Imigrantes. Após serem registrados e matriculados, os estrangeiros

\footnotetext{
${ }^{1}$ São Paulo, Secretaria da Agricultura, Relatório da Agricultura 1928... Dr. Fernando Costa, 342-4.

${ }^{2}$ Leis provinciais n. 28 de 29 de março de 1884; n. 14 de 11 de fevereiro de 1885 ; n. 21 de março de 1885. Sobre a Hospedaria de Imigrantes, ver: Odair da Cruz Paiva e Soraya Moura, Hospedaria de Imigrantes de São Paulo (São Paulo: Paz e Terra, 2004).
} 
recebiam atendimento médico, alojamento e alimentação por até oito dias. ${ }^{3}$ Apesar de nem todos os imigrantes que entraram no estado terem utilizado suas instalações, a Hospedaria funcionou como um centro de recepção e agência de trabalho tanto para imigrantes subsidiados - que deveriam necessariamente ser recebidos no local - quanto espontâneos e mesmo brasileiros de outros estados que a procuravam em busca de colocação nas fazendas.

Todos os imigrantes que passaram pela Hospedaria foram registrados em livros de matrículas, onde eram anotadas diversas informações como nome, idade, nacionalidade, procedência e destino no estado. Esse material, sob curadoria do Museu do Imigrante e que hoje se encontra no Arquivo do Estado de São Paulo, foi em parte digitalizado e as informações abertas para consulta online pelo nome e sobrenome dos imigrantes. Esses registros individuais representam uma fonte rica e quase inexplorada sobre a imigração, o perfil dos imigrantes e sua distribuição em São Paulo. É essa base de dados que será utilizada neste capítulo. ${ }^{4}$

Ainda que os registros de matrícula tenham se iniciado em 1882, foi apenas na década de 1890 que passou a haver divulgação oficial e sistemática do movimento de imigrantes na Hospedaria, por meio dos Anuários Estatísticos e dos Relatórios da Secretaria da Agricultura, principalmente. O período de 1882 a 1895 é repleto de lacunas na documentação oficial, especialmente as relacionadas à distribuição de imigrantes nos municípios paulistas. Este capítulo apresenta uma tentativa de preencher parte dessas lacunas, por meio de uma análise detalhada da distribuição e colocação dos imigrantes, utilizando os registros de matrícula da Hospedaria de Imigrantes para todo o período de 1882 a 1920.

Nas seções a seguir, apresenta-se, primeiro, o espaço geográfico de regiões e municípios do estado de São Paulo em que as seções e os capítulos seguintes serão baseados. Na sequência, descreve-se a estrutura da Hospedaria de Imigrantes e como os seus registros de matrícula foram organizados. Mais adiante é apresentada uma nova série de imigração que permitirá reconstituir tanto as entradas quanto o destino das famílias imigrantes desde o início da imigração subsidiada. Os dados serão organizados

\footnotetext{
3 São Paulo, Secretaria da Agricultura, Commercio e Obras Públicas, Departamento Estadual do Trabalho, A Imigração e as condições do trabalho em São Paulo (São Paulo, Typ Brasil, de Rothschild \& cia. 1915), 25.

${ }^{4}$ Agradecemos ao Arquivo do Estado de São Paulo pela cessão da base de registros dos imigrantes da Hospedaria de Imigrantes.
} 
por nacionalidade e por ano para o conjunto da província e do estado de São Paulo. Outras características individuais dos imigrantes contidas nos registros da Hospedaria serão igualmente resumidas, como por exemplo a composição familiar, a proporção de homens e mulheres, ocupação e a modalidade de imigração - se espontânea ou subsidiada. Essa análise será especialmente importante para os capítulos seguintes dessa tese, quando serão abordados os imigrantes proprietários de terra e a distribuição geográfica de suas propriedades.

\subsection{A divisão regional do estado de São Paulo}

O estudo da distribuição de imigrantes entre os municípios paulistas apresentado nesse capítulo e a análise sobre apropriação territorial no capítulo seguinte requerem, em primeiro lugar, a adoção de uma unidade territorial comparável ao longo do tempo. ${ }^{5}$ A expansão cafeeira e a abertura da fronteira agrícola por meio da expansão das ferrovias levaram ao surgimento de dezenas de novos municípios no período estudado. Em 1886, havia 122 municípios na província. ${ }^{6}$ Em 1905 o já estado de São Paulo era composto por 171 municípios, aumentando para 203 em $1920 .^{7}$ As novas 81 municipalidades entre 1886 e 1920 surgiram mediante desmembramento de unidades já existentes. Consequentemente, a localização das propriedades rurais enquanto parte de um município específico acabou se alterando no decorrer do tempo. Um exemplo é o município de Bauru, que em 1905 registrava 341 estabelecimentos rurais, e que em 1920 possuía apenas 123 propriedades, como resultado das sucessivas divisões ocorridas em sua área original com o surgimento de cinco novos municípios. Ao computar os seis municípios que em 1920 constituíam a área de Bauru em 1905, observa-se um total de 3.351 propriedades rurais. O uso de unidades territoriais formadas por grupos de municípios que mantenham limites comparáveis torna-se, então, um primeiro passo para a análise da evolução das propriedades rurais de imigrantes no período aqui investigado.

\footnotetext{
${ }^{5}$ Milliet, "Roteiros do café," 7-12; Camargo, Crescimento, 23-49.

${ }^{6}$ São Paulo, Relatório apresentado ao Exm. Sr. Presidente da Província de São Paulo pela Commissão Central de Estatistica (São Paulo, Leroy King Bookwalter, Typographia King, 1888).

${ }^{7}$ São Paulo, Anuário Estatístico de São Paulo para o ano de 1905, v. 1 (São Paulo: Typ. Espíndola e Cia. 1907); Brasil, Directoria Geral de Estatística, Recenseamento do Brasil, Realizado em 1 de Setembro de 1920 , v. IV, 1a. Parte (Rio de Janeiro: Typ. da Estatística, 1926).
} 
Nos estudos sobre a expansão cafeeira, vários autores buscaram classificar as regiões que formavam a área agrícola do estado de São Paulo. ${ }^{8}$ Dado o objetivo de estudar as propriedades rurais de estrangeiros em São Paulo, adota-se aqui a divisão empregada por Thomas Holloway, que se baseia por sua vez na divisão regional de Sérgio Milliet. ${ }^{9}$ Como observa Renato Colistete, "as principais diferenças da versão de Holloway em relação à de Camargo são a manutenção da zona da Paulista de acordo com a divisão original de Milliet (apenas integrando a Alta Paulista à zona Noroeste, em vez da divisão "Paulista", "Alta Paulista" e "Baixa Paulista") e a criação de uma nova região em torno de Sorocaba, desmembrada da zona da Capital". ${ }^{10}$ Os mapas nas Figuras 2.1 e 2.2 abaixo apresentam a divisão do estado de São Paulo em regiões em 1905, com 171 municípios, e 1920, com 204 municípios.

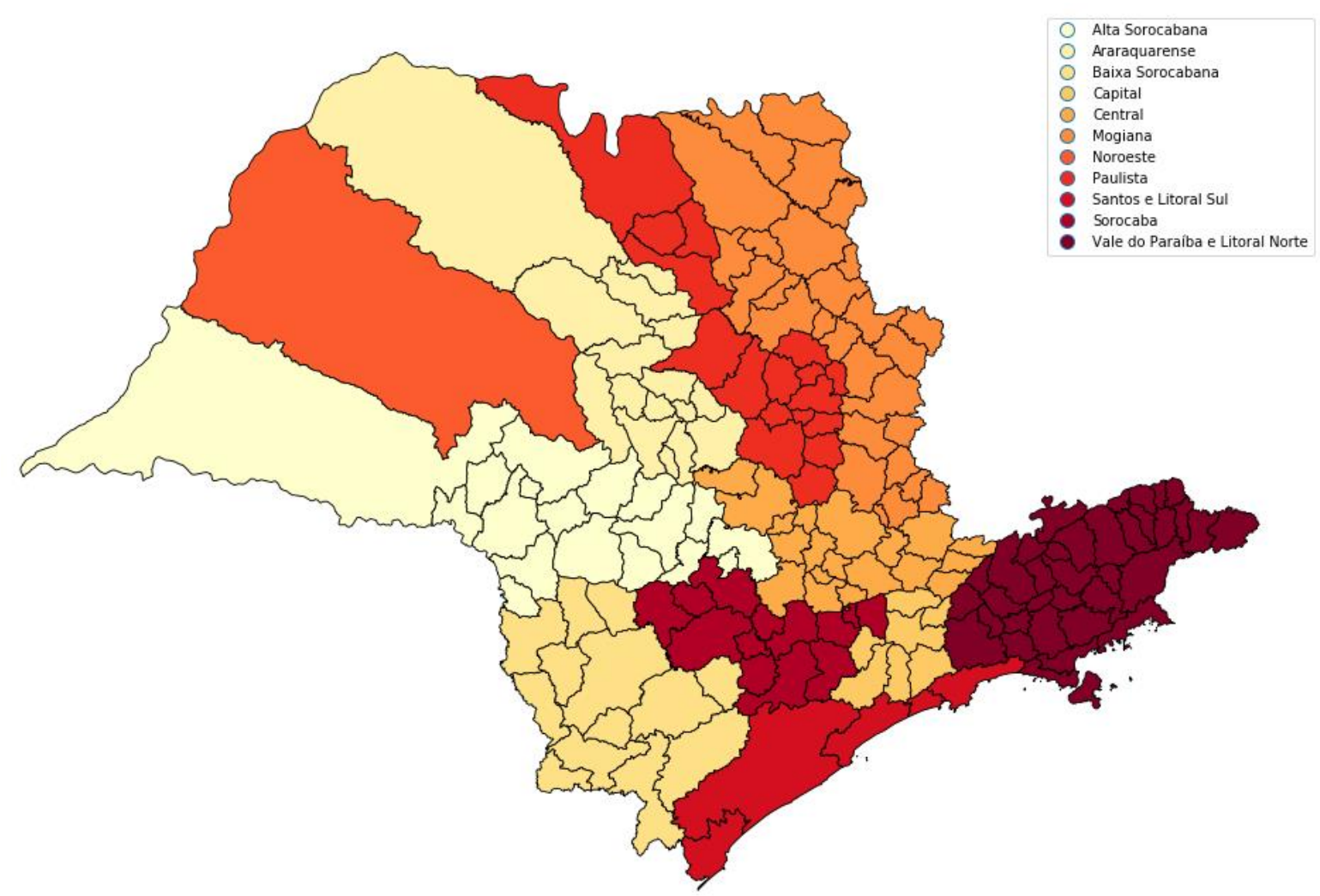

Figura 2.1 - Divisão do estado de São Paulo em regiões, 1905

Nota: Divisão regional de acordo com Holloway, Imigrantes, cap. 2.

\footnotetext{
${ }^{8}$ Pierre Deffontaines, "Pays et paysages de l'État de Saint-Paul (Brésil). Première esquisse de division régionale (primier article)," Annales de Géographie 45 (1936): 50-7; Pierre Deffontaines, "Pays et paysages de l'État de Saint-Paul (Brésil). Première esquisse de division régionale (deuxième article)," Annales de Géographie 45 (May 1936): 160-74; Milliet, "Roteiros do café," 5-72; Sergio Milliet, "O desenvolvimento da pequena propriedade no estado de São Paulo (1939)," in Roteiros do café e outros ensaios, Sergio Milliet (São Paulo: Coleção Departamento de Cultura, 1941), 73-121.

${ }^{9}$ Holloway, Imigrantes, cap. 2.

${ }^{10}$ Renato Colistete, "Regiões e Especialização na Agricultura Cafeeira: São Paulo no Início do Século XX," Revista Brasileira de Economia 69, n. 3 (jul./set. 2015): 334.
} 


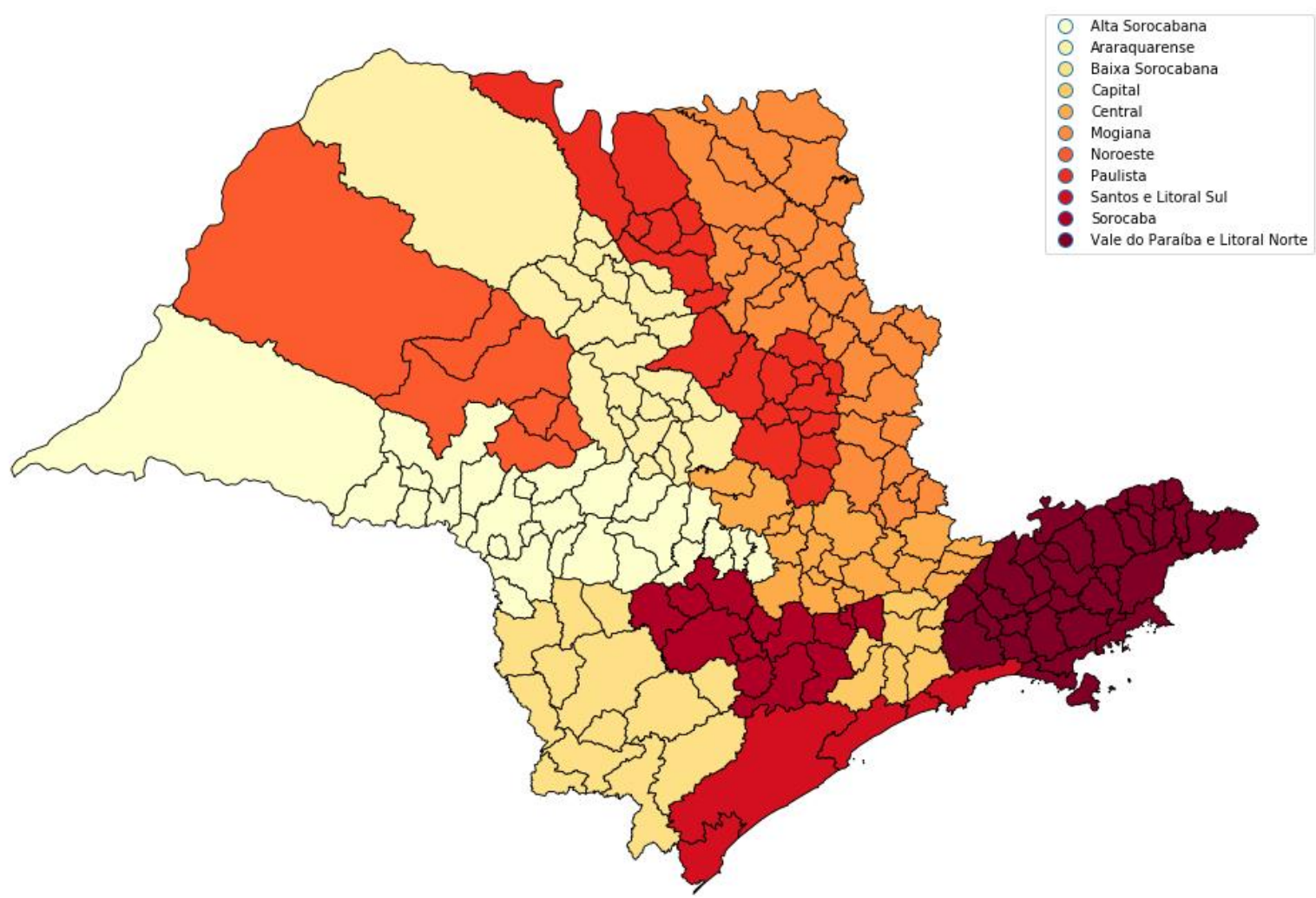

Figura 2.2 - Divisão do estado de São Paulo em regiões, 1920

Nota: Divisão regional de acordo com Holloway, Imigrantes, cap. 2.

São, portanto, ao todo onze regiões: Capital, Vale do Paraíba e Litoral Norte, Sorocaba, Central, Mogiana, Paulista, Araraquarense, Noroeste, Alta Sorocabana, Baixa Sorocabana e Santos e Litoral Sul, com seus respectivos municípios criados entre 1905 e 1920. No Anexo A2.1 são apresentadas as onze regiões e seus municípios nesses dois anos.

A região do Vale do Paraíba e Litoral Norte, cuja participação na agricultura paulista já estava em declínio no final do século XIX e começo do XX, foi pioneira na introdução do cultivo do café no estado e dominou sua produção até a década de 1870. Dessa região, o café transpôs a Serra do Mar rumo a outras áreas do interior do estado de São Paulo nas décadas seguintes. A região Central, a primeira onde foi utilizada mão de obra imigrante no trabalho nas fazendas, no começo do século XX já vinha diversificando sua produção agrícola e perdendo espaço no cultivo do café para as regiões da Mogiana e Paulista, que despontaram no final do século XIX. ${ }^{11}$

\footnotetext{
${ }^{11}$ Monbeig, Pioneiros, 167-72.
} 
A cultura do café chegou à zona Central na década de 1850 e a avançou para a Mogiana e Paulista nas décadas seguintes, acompanhada pela expansão da ferrovia. Durante os anos 1880 e 1890 essas regiões viveram o apogeu da cafeicultura. Nas primeiras décadas do século XX, tanto a Mogiana quanto a Paulista continuaram sendo as principais zonas cafeeiras do estado, mas começavam a perder espaço para as zonas da nova fronteira agrícola - Araraquarense, Noroeste e Alta Sorocabana. ${ }^{12}$

A região da Araraquarense constituía um espaço intermediário entre as áreas de povoamento e exploração mais antigas e as zonas mais recentes, tendo um desenvolvimento mais rápido a partir de 1895 concomitante à expansão da estrada de ferro de mesmo nome. Em 1905, a Araraquarense e a Alta Sorocabana ainda eram regiões relativamente pouco povoadas, mas nos quinze anos seguintes, à medida em que foram integradas ao restante do estado pela expansão das ferrovias, receberam um afluxo de nacionais e imigrantes e tiveram seu território ocupado com culturas diversas. A região Noroeste contava apenas com um município em 1905, Bauru, ligado ao resto do estado pela estrada de ferro Sorocabana nesse mesmo ano. Nos anos seguintes a região recebeu a estrada de ferro Noroeste e um ramal da estrada de ferro Paulista. ${ }^{13}$

Entre 1910 e 1919 a região Noroeste começou a ganhar expressão na produção cafeeira, apesar do maior peso econômico do café continuar concentrado na Mogiana. Apenas na década de 1920 o eixo da economia cafeeira se deslocaria da Mogiana e da Paulista para a Araraquarense, Noroeste e Alta Sorocabana, acompanhado do crescimento dos antigos e do surgimento de novos municípios e da entrada acelerada de imigrantes, que passaram a exibir preferência por essas regiões. ${ }^{14}$ Nas seções a seguir, apresentam-se distribuição e colocação dos imigrantes utilizando os registros de matrícula da Hospedaria de Imigrantes, compreendendo todo o período de 1882 a 1920.

\subsection{A Hospedaria de Imigrantes e os registros de matrícula}

Inaugurada em 1888 em substituição à Hospedaria do Bom Retiro, a Hospedaria de Imigrantes construída no Brás buscou melhorar e aumentar o controle sobre os serviços de recepção de estrangeiros na capital e de envio para o trabalho nas

\footnotetext{
12 Milliet, "Roteiros," 41-66.

${ }^{13}$ Holloway, Imigrantes, 37-46.

${ }^{14}$ Monbeig, Pioneiros, 184-92.
} 
fazendas. ${ }^{15}$ A todos os imigrantes que estavam em São Paulo pelo programa de subsídios era obrigatória a passagem pela Hospedaria, onde eram matriculados e recebiam alojamento e alimentação por até oito dias. Da Hospedaria os imigrantes apenas saíam mediante a assinatura de um contrato de trabalho, com o transporte de São Paulo até as fazendas do interior ocorrendo a partir da própria estação ferroviária do estabelecimento. ${ }^{16} \mathrm{O}$ governo provincial e depois estadual assumia todos os custos, os quais eram substancialmente elevados para grande parte das famílias imigrantes. ${ }^{17}$ Estrangeiros com recursos próprios, imigrantes que já haviam estado nas fazendas do interior, e migrantes nacionais e estrangeiros de outros estados também costumavam procurar o auxílio da Hospedaria para colocação nas fazendas. Aqueles que tinham interesse em adquirir terras em núcleos coloniais recorriam da mesma forma aos serviços de colonização disponíveis. As vantagens da Hospedaria e dos serviços oferecidos por ela foram frequentemente destacados por representantes de governos estrangeiros em missão no Brasil. ${ }^{18}$

O rígido controle sobre o imigrante subsidiado fazia parte do objetivo do governo de São Paulo de garantir o suprimento de mão de obra para as fazendas. Nas próprias dependências da Hospedaria funcionaram a Inspetoria de Terras, Colonização e Imigração, órgão do governo central existente desde 1876 e responsável pela promoção da imigração e colonização e que, posteriormente, tornou-se a Diretoria de Terras, Colonização e Imigração. Essa Diretoria de Terras mudou de nome novamente em 1906, para Agência de Colonização e Trabalho, subordinada à Secretaria da Agricultura do estado de São Paulo. Por fim, em 1911, a Agência de Colonização e Trabalho foi reorganizada com o nome de Agência Oficial de Colocação, do Departamento Estadual do Trabalho, estrutura que perdurou até 1930. As funções da Agência, de qualquer forma, permaneceram semelhantes com o passar dos anos, sobretudo a de servir de apoio aos fazendeiros para contratação de mão de obra para suas propriedades. Dessa forma, a Hospedaria de Imigrantes tornou-se um verdadeiro centro de recrutamento de

\footnotetext{
${ }^{15}$ Paulo C. Gonçalves "A Hospedaria de Imigrantes de São Paulo: um novo espaço para o recrutamento de braços europeus pela economia cafeeira," in Brasil-Portugal. Pontes sobre o Atlântico: múltiplos olhares sobre a e/imigração, orgs. Lená Medeiros de Menezes; Fernando Sousa (Rio de Janeiro: EdUERJ, 2017), 254-55. Sobre as primeiras hospedarias de imigrantes em São Paulo, ver: Rosa Guadalupe Soares Udaeta, "Nem Brás, nem Flores: Hospedaria de imigrantes da cidade de São Paulo (1875-1886)" (Dissertação de Mestrado, FFLCH/USP, 2016).

${ }^{16}$ Holloway, Imigrantes, 86-88.

${ }^{17}$ Holloway observa que uma passagem de trem entre a capital e o Oeste paulista poderia chegar a custar o equivalente a uma semana de trabalho por pessoa. Holloway, Imigrantes, 97.

${ }^{18}$ Ver, por exemplo, o Relatório de 1888 de De Grelle, Étude du Brésil.
} 
trabalhadores - o que Pierre Denis chamou de "mercado de homens" -, sendo nela que ocorria, na maioria das vezes, o primeiro contrato de trabalho dos estrangeiros que chegavam em São Paulo. ${ }^{19}$

Seguindo os procedimentos então vigentes, os fazendeiros interessados em contratar imigrantes informavam previamente à Agência de Colonização o número de colonos que desejavam e os termos do contrato que estariam dispostos a oferecer. Os contratos eram feitos sob supervisão da Agência de acordo com um modelo padrão, em conformidade com os contratos em uso. Os próprios fazendeiros ou seus representantes eram autorizados, pessoalmente ou por meio de seus emissários, a negociar com os imigrantes as condições dos contratos, utilizando intérpretes oficiais quando necessário. Os colonos podiam, então, escolher a oferta que mais lhe interessasse entre as disponíveis. Escolhido o destino que mais conviesse, o imigrante e o fazendeiro, perante um funcionário da Agência, firmavam os termos do contrato. Ao imigrante era fornecida uma caderneta de trabalho contendo, na sua língua materna, as leis e disposições referentes à contratação do trabalho e aos deveres e obrigações do colono e do fazendeiro. Era nessa caderneta que eram registrados os salários e despesas dos imigrantes e suas famílias. Além disso, a caderneta servia como documento oficial para qualquer queixa relativa à cobrança dos salários. ${ }^{20}$ Concluídos os trâmites da contratação, o imigrante e sua família recebiam passagem gratuita de trem e o despacho de suas bagagens até seu destino final.

Os imigrantes em trânsito pela Hospedaria tiveram seus dados registrados nos livros de matrícula, onde, dentre outras informações, eram anotados nome e sobrenome, idade, sexo, religião, profissão, grau de instrução, porto de procedência, nome do navio e o local de destino no estado de São Paulo. As primeiras matrículas ocorreram ainda na antiga Hospedaria do Bom Retiro, criada em 1882, e estenderam-se até 1958, quando passaram a ser usadas fichas catalográficas até o encerramento das atividades da Hospedaria nos anos $1970 .{ }^{21}$ Por conterem dados individuais, os registros de matrículas permitem mapear o movimento dos estrangeiros saídos da Hospedaria para todos os

\footnotetext{
${ }^{19}$ Denis, Brazil, 209; Vangelista, Os braços, 56.

${ }^{20}$ Juan Solorzano y Costa, El estado de São Paulo (Brasil). Estudio acerca de la verdadera situación del mismo en 1912-13 (São Paulo: Talleres tipográficos del Diario Español, 1913), 100-3; "Dados para a Historia da Immigração e Collonização de São Paulo," Boletim do Departamento Estadual do Trabalho 5, n. 19 (2 $2^{\circ}$ trimestre de 1916): 188-91.

21 "Livros de Registro da Hospedaria de Imigrantes". Todos os livros digitalizados podem ser encontrados em: http://www.inci.org.br/acervodigital/livros.php; Odair da Cruz Paiva, "Arquivos da Imigração no Contexto da Hospedaria de Imigrantes de São Paulo," Patrimônio e Memória, 5, n. 2 (dez. 2009): 84-5.
} 
municípios do estado de São Paulo. Além disso, com esses dados é possível estudar várias características individuais dessas pessoas, o que faz de tais registros uma fonte única e extremamente rica.

Em geral, os trabalhos que estudaram a imigração em São Paulo utilizaram as estatísticas publicadas em documentos oficiais do governo provincial e estadual. Nesses documentos é possível encontrar dados agregados anuais, às vezes divididos por nacionalidades, de imigrantes entrados na província/estado e que remontam a 1823 . No entanto, com exceção do ano de 1886, somente após 1896 o movimento dos imigrantes transferidos da Hospedaria para os municípios passou a ser publicado regularmente, primeiro nos Anuários Estatísticos do Estado de São Paulo e, depois de 1900, nos Relatórios da Secretaria da Agricultura do Estado de São Paulo. Desta forma, a falta de sistematização dos registros da Hospedaria de Imigrantes anteriores a 1896 deixou uma lacuna significativa sobre a distribuição dos estrangeiros nos primórdios do programa de subsídios do governo de São Paulo.

Os registros de imigrantes analisados a seguir fazem parte de uma base de dados com cerca de 1 milhão e 574 mil imigrantes entrados na Hospedaria entre 1882 e 1920. Daqui em diante, essa base de dados, compilada por funcionários do Arquivo Público do Estado de São Paulo através da transcrição dos livros de registro de matrícula de imigrantes da Hospedaria, será chamada de "base de dados da Hospedaria de Imigrantes". Com o passar do tempo, os livros de registro originais foram se tornando mais complexos, abrangendo informações adicionais dos imigrantes. A base de dados da Hospedaria de Imigrantes combina os registros de todos os livros que foram digitalizados em um único documento, fazendo com que algumas informações existam apenas para uma parte das observações. A complexidade do trabalho com uma fonte histórica dessa magnitude faz dela um território pouco explorado pela historiografia. ${ }^{22}$

\footnotetext{
${ }^{22}$ Os trabalhos que utilizam os dados brutos dos registros de matrícula da Hospedaria o fizeram de forma pontual, estudando uma característica ou um período específico da imigração em São Paulo. Dentre eles, pode-se citar: Maria Silvia C. B. Bassanezi, "Família e força de trabalho no colonato. Subsídios para a compreensão da dinâmica demográfica no período cafeeiro," Textos NEPO, n. 8 (Jul. 1986): 3-100; Maria Silvia C. B. Bassanezi e Rosana Baeninger, "Uma fonte para os estudos de população: os registros da Hospedaria de imigrantes de São Paulo," Textos NEPO, n. 7 (Jun. 1986): 27-43; Lucy Maffei Hutter, Imigração italiana em São Paulo (1880-1889): os primeiros contatos do imigrante com o Brasil (São Paulo: IEB, 1972); Maria Izilda Santos de Matos e Sênia Bastos, "Portugueses em São Paulo. Registros e Ingressos (1912): Hospedaria do Imigrante - Listas de Bordo e Livros de Registro," in Nas duas margens. Os portugueses no Brasil, eds. Ismênia Martins e Maria Izilda Santos de Matos (Porto: CEPESE/Afrontamento, 2009), 269-87. Mais recentemente, Leonardo Monastério usou a mesma base de dados para estudar os sobrenomes e ancestralidades no Brasil. Leonardo Monasterio, "Surnames and ancestry in Brazil," PLoS ONE.12, n. 5 (2017); Leonardo Monasterio e Daniel Lopes também usaram a
} 
Uma das maiores dificuldades encontradas na análise dos dados dos livros da Hospedaria diz respeito à qualidade das informações transcritas. Nos livros originais, os registros completos apenas eram feitos para os "chefes de família". Possivelmente, para agilizar o processo de registro do imigrante na sua chegada à Hospedaria, abreviações eram feitas em todos os campos de informação. ${ }^{23}$ Dessa forma, a variável de "destino", por exemplo, que traz a informação do destino tomado pelo imigrante ao sair da Hospedaria, originalmente possuía quase 9.000 entradas distintas - ou seja, em tese mais de 9.000 destinos diferentes. O mesmo ocorreu com outras variáveis, como "nacionalidade", que possui aproximadamente 1.100 entradas nos registros originais da Hospedaria. O campo de "profissão" é outro exemplo, com mais de 4.000 tipos de ocupações anotados nos livros originais. A transcrição dos registros feita pelos funcionários do Arquivo Público manteve todas as informações originais dos livros. Dessa forma, o primeiro passo para análise desses dados foi selecionar as variáveis de interesse para esta tese e realizar um processo de limpeza e padronização das entradas contidas nos registros de imigrantes.

A informação de "destino" disponível na base de dados da Hospedaria de Imigrantes mostrou-se a mais difícil de ser sistematizada. Muitos imigrantes tiveram anotados como seu destino final o nome de estações ferroviárias, distritos, fazendas ou do fazendeiro para onde se destinavam, em vez do município. Nesse caso, a solução foi realizar um mapeamento das estações ferroviárias e dos distritos existentes no estado de São Paulo no período relevante para que fosse possível localizar corretamente o município de destino do imigrante à época. A sucessiva criação de novos municípios, desmembramentos e até mesmo extinção de municípios existentes dificultou particularmente o mapeamento correto do destino dos imigrantes na província e no estado de São Paulo. A fim de minimizar erros, foram consultadas diferentes fontes que auxiliaram na reconstituição dos locais de destino dos imigrantes, incluindo dados históricos de municípios do IBGE e do governo de São Paulo, bem como informações sobre estações ferroviárias e localidades postais. ${ }^{24}$ Quando o destino apareceu com o

base para estimar o efeito da imigração não-ibérica para o Brasil. Leonardo Monastério e Daniel Lopes, "Brasil sem imigrantes: estimativas de longo prazo baseadas em microdados," Texto para Discussão 2435 IPEA (nov. 2018).

${ }^{23}$ Dessa forma, "católico", por exemplo, aparece como "CATH.”, “CAT.”, "C.", "C.CO”; "italiano" poderia vir como "IT.", "ITAL.”, "I.”; Ribeirão Preto era anotado como "Rib. Preto", "R. Preto", "Rib. P.to", "Rib. P.".

${ }^{24}$ Ministério da Viação e Obras Públicas, Estatística das estradas de ferro do Brasil, relativa ao ano de 1920 (Rio de Janeiro: Soares Dias \& C., 1924); Ralph Mennucci Giesbrecht, "Estações ferroviárias do 
nome de uma municipalidade legível ou abreviado de forma a permitir sua clara identificação, apenas substituiu-se a entrada pelo nome completo do município. Quando um destino não correspondeu diretamente a um município, buscou-se identificar primeiro a estação ferroviária. Caso tenha sido possível a localização, o município ao qual aquela estação pertencia no período foi identificado como destino do imigrante.

Apesar dos esforços, foi necessário adotar convenções em certos casos, uma vez que a localização das estações mudava conforme surgiam novos municípios. ${ }^{25}$ Como o período de interesse é de 1886 a 1920, optou-se por manter como destino do imigrante o município ao qual a estação pertencia antes de 1920. Quando o destino indicado não era uma estação ferroviária, recorreu-se aos dicionários postais dos Almanaks Laemmert para tentar localizá-lo. Se o destino não foi localizado por nenhum dos métodos empregados, imputou-se a categoria "não localizado" para facilitar a análise posterior dos dados. Houve ainda outros casos em que o imigrante teve dois ou mais destinos anotados, sem explicação do motivo. Nessa situação, optou-se por considerar o último destino como o destino final desse imigrante.

Um outro problema enfrentado para padronizar as informações da base de dados da Hospedaria do Imigrante foi que, como já observado, as informações mais relevantes eram anotadas apenas para o chefe da família. Para uma família composta por cinco membros, por exemplo, registrava-se o nome de todos, mas as informações de sobrenome, nacionalidade, destino e religião, entre outras, eram atribuídas apenas ao chefe daquela família, normalmente o pai ou esposo. Para preencher as lacunas dos demais membros da família, elaborou-se um procedimento em linguagem Python que usa a variável de parentesco como índice para preencher as demais variáveis do banco de dados. Apesar da base de dados original possuir um campo chamado "número da família”, este não se mostrou um bom identificador único de família, visto que um mesmo número foi utilizado em diferentes famílias em anos distintos.

O procedimento empregado com o programa em Python mostrou-se efetivo para organizar a variável de parentesco. Desta forma, as mesmas informações que o chefe da família possuía foram associadas aos demais membros daquela família, caso esses não

Brasil," múltiplos acessos, http://estacoesferroviarias.com.br/; “Cidades@," IBGE, múltiplos acessos, https://cidades.ibge.gov.br/; "Histórico da Formação dos Municípios," SEADE, múltiplos acessos, http://produtos.seade.gov.br/produtos/500anos/index.php?tip=hist; "Dicionários postais brasileiros," in Almanak Laemmert, diversos anos.

${ }^{25}$ Por exemplo, a estação "Glicério" pertenceu a Bauru até 1913, depois passou a fazer parte do município de Penápolis até 1925, sendo então transferida para o município de Glicério. 
possuíssem informações próprias. Considerou-se como "Chefe" todos os indivíduos que na variável parentesco apareciam como "chefe", "esposo", "pai", "marido" ou "mãe". Decidiu-se classificar "mãe" como "chefe" após perceber-se que, na organização das famílias que tinham explicitamente um chefe ou um pai, a mulher aparecia sempre como "esposa" ou "mulher". Analisando os dados originais foi possível observar que as mulheres classificadas como "mãe" haviam emigrado com seus filhos e, portanto, eram as chefes da família. A Imagem 2.1 abaixo traz um exemplo dos livros de registros de matrícula dos imigrantes da Hospedaria e dá uma ideia da organização original das informações que serve de base para este capítulo.

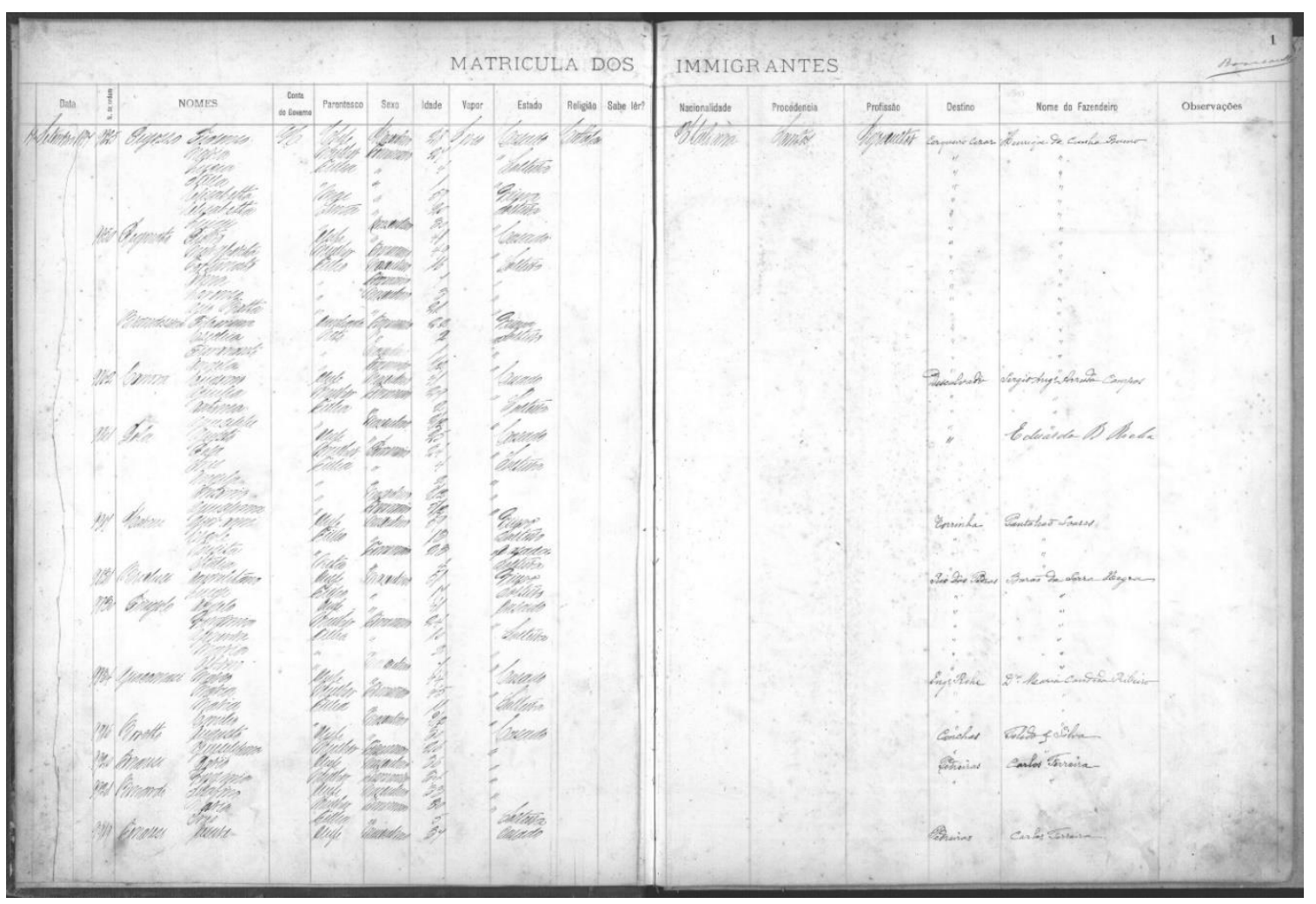

Imagem 2.1 - Registro de matrícula de imigrantes, Livro 060, p. 001.

Fonte: INCI - Instituto de Preservação e Difusão da História do Café e da Imigração. Disponível em http://www.inci.org.br/acervodigital/upload/livros/pdfs/L060_001.pdf.

Os procedimentos adotados de limpeza e preenchimento dos dados inexistentes da base de dados da Hospedaria de Imigrantes, bem como a necessidade de definir os destinos não encontrados na variável "não localizado", podem resultar em um viés de subestimação do número de imigrantes deslocados para uma determinada localidade e superestimação em outras. Não foi possível saber o motivo de alguns imigrantes não terem o destino anotado em seus registros. O fato de que nem todos os livros de matrícula terem sido digitalizados também contribui para a subestimação dos dados. Por 
exemplo, Thomas Holloway relata, a partir de documentos oficiais agregados, que 1.084.649 imigrantes entraram na Hospedaria entre 1893 e $1920 .^{26}$ No mesmo período, a base de dados produzida nesta tese, e elaborada por meio dos procedimentos mencionados anteriormente, chegou a um número de 818.520 imigrantes. Enquanto nos anos de 1886 a 1900 foi possível mapear o destino de 213.406 (34\%) dos 628.193 matriculados na Hospedaria de Imigrantes, entre 1901 e 1920 obteve-se com sucesso o registro de destino para 449.674 (93\%) dos 484.647 imigrantes. Apesar dos casos não localizados e das dificuldades de identificação de nomes e lugares, a distribuição obtida após a limpeza e reclassificação dos dados originais da Hospedaria parece altamente representativa.

Com os resultados obtidos na construção da base de dados desta tese, será examinada a seguir a distribuição dos imigrantes no interior do estado entre 1886 a 1920 e o perfil dos imigrantes em São Paulo. Essa base de dados base será empregada também para o cruzamento de informações individuais com as dos imigrantes recenseados como proprietários na Estatística Agrícola e Zootécnica no ano agrícola de 1904-5 no Capítulo 4, o que justifica o trabalho detalhado de organização das informações. ${ }^{27}$

\subsection{A imigração segundo os registros de matrícula da Hospedaria de Imigrantes}

Os imigrantes que passaram pela Hospedaria de Imigrantes entre 1886 e 1920 refletiam bem as prioridades da elite cafeeira e da política imigratória paulista. ${ }^{28}$ Nesses 35 anos, imigrantes de 45 nacionalidades distintas foram matriculados na Hospedaria. Três dessas nacionalidades, no entanto, somaram quase $90 \%$ do total: os italianos $(54,5 \%)$, os espanhóis $(21,9 \%)$ e os portugueses $(11,5 \%)$. Após estes grupos, vieram os brasileiros (5\%), os alemães (3\%) e os japoneses (1\%). Ao longo de todo o período, as regiões cafeeiras da Mogiana, Paulista e Araraquarense receberam juntas aproximadamente $70 \%$ de todos os italianos, $62 \%$ dos espanhóis, $48 \%$ dos portugueses e mais da metade das demais nacionalidades. Apenas 2,2\% dos italianos, 3,6\% dos portugueses e $2,4 \%$ dos espanhóis se deslocaram para as regiões mais antigas ou não

\footnotetext{
${ }^{26}$ Holloway, Imigrantes, 90-1.

${ }^{27}$ Daqui em diante, essa estatística será chamada de Estatística Agrícola de 1905.

${ }^{28}$ Ver o Capítulo 1, seção 1.2.
} 
dedicadas à cafeicultura - Vale do Paraíba e Litoral Norte, Santos e Litoral Sul, Baixa Sorocabana e Sorocaba.

Cerca de 36\% dos imigrantes que transitaram pela Hospedaria entre 1886 e 1920 tinham menos de 15 anos e $60 \%$ entre 15 e 50 anos. Desse total, 58,7\% dos imigrantes eram do sexo masculino. ${ }^{29}$ Além disso, $30 \%$ dos imigrantes foram listados como chefes de família e 44\% apareciam como "filho" ou "filha" nos registros da Hospedaria. Mesmo com o peso desproporcional do sexo masculino, a alta parcela de "chefes" aponta para a importância da imigração em família. ${ }^{30} \mathrm{O}$ complexo sistema de remuneração empregado nas fazendas, com pagamentos por tarefas e volume, incentivava o trabalho de todos os membros em idade ativa visando maximizar os ganhos da família. O próprio sistema de subsídios empregado pelo governo especificava, principalmente no seu início, a preferência por famílias de imigrantes. ${ }^{31}$ É possível que tenha havido uma parcela importante de imigração de solteiros, principalmente de forma espontânea, que não foi captada pela imigração que passou pela Hospedaria. ${ }^{32}$ No entanto, visto que a Hospedaria recebeu $60 \%$ de todos os estrangeiros entrados em São Paulo, parece razoável assumir que a imigração de pessoas sozinhas não tenha predominado no estado.

Os dados anteriores também mostram a diferença da imigração para São Paulo comparada com outras partes do Novo Mundo que receberam contingentes consideráveis de imigrantes no mesmo período. Nos Estados Unidos, Canadá e Argentina predominou a imigração de homens jovens, solteiros e em idade ativa em busca de emprego temporário ou permanente, com o objetivo de acumular poupança. ${ }^{33}$

\footnotetext{
${ }^{29}$ Outros trabalhos diferem do resultado aqui apresentado. Thomas Holloway, analisando os registros de entrada no Porto de Santos de 1882-98 e 1908-34 mostra que os homens eram 65\% dos imigrantes. Thomas Holloway, Migration and mobility: immigrants as laborers and landowners in the coffee zone of São Paulo, Brazil, 1886-1934 (PhD thesis, University of Wisconsin, 1974): 221. Warren Dean afirma que entre 1876 e 1908 as mulheres não eram mais do que $25 \%$ do contingente de italianos. Dean, Rio Claro, 72.

${ }^{30} \mathrm{O}$ temor entre os fazendeiros de ocorrer no Brasil o fenômeno da migração temporária que ocorria na Argentina - inmigrantes golondrinas - fez com que o subsídio fosse direcionado apenas para famílias. Holloway, Imigrantes, cap. 3; Klein, "European,” 208.

${ }^{31}$ Lei n. ${ }^{\circ} 14$ de 11 de fevereiro de 1885; SPI, Relatório, Anexo A4; São Paulo, Anais da Assembleia Legislativa Provincial de São Paulo, Sessão de 17 de janeiro de 1888, 31-6; A Província de São Paulo, 18/01/1888, 1; SPI, Relatorio da Directoria ao exm. Sr. Conde de Parnahyba, presidente da Provincia de S. Paulo (São Paulo: Typ. Jorge Seckler \& Comp., 1888): 6.

${ }^{32}$ Registro de Matrícula da Hospedaria de Imigrantes.

${ }^{33}$ Timothy J. Hatton e Jeffrey G. Williamson, "What Drove the Mass Migrations from Europe in the Late Nineteenth Century?," Population and Development Review 20, n. 3 (Sep., 1994): 535; Timothy J. Hatton e Jeffrey G. Williamson, The age of mass migration (New York: Oxford University Press, 1998), 11; Herbert Klein, "Migração Internacional na História das Américas," in Fazer a América, org. Boris Fausto (São Paulo: EDUSP, 2000), 24.
} 
Nesses destinos, a imigração foi liderada por imigrantes jovens e sem auxílio governamental, contando com a ajuda de imigrantes prévios já estabelecidos. A ajuda fornecida por essa rede de auxílio de amigos e parentes ocorria por meio de envio de dinheiro, pagamento de passagens, acomodação e auxílio para encontrar emprego. ${ }^{34} \mathrm{~A}$ própria presença de imigrantes de uma determinada região de origem em um determinado local no país de destino foi apontada como tendo influência considerável na atração de novos imigrantes da mesma origem para a mesma localidade. ${ }^{35}$

\subsubsection{A distribuição geográfica dos imigrantes em São Paulo}

A cafeicultura no Oeste paulista, seja na área onde os cafezais já estavam consolidados, seja nas áreas de "boca de sertão", onde a cultura cafeeira espalhou-se ao longo das duas primeiras décadas do século $\mathrm{XX}$, demandou continuamente mão de obra para o trabalho de preparo do solo, cultivo e colheita dos grãos. Cerca de $80 \%$ dos imigrantes que deixaram a Hospedaria de Imigrantes entre 1886 e 1920 seguiram em direção das regiões da Mogiana, Paulista, Central, Araraquarense e Alta Sorocabana. ${ }^{36}$ Onde a cafeicultura não penetrou ou onde já estava em declínio, o encaminhamento de imigrantes da Hospedaria teve pouca expressão. ${ }^{37}$

A procura pelos imigrantes nas regiões cafeeiras era intensa, com jornais da época relatando que fazendeiros chegavam a esperar semanas para conseguir contratar estrangeiros para seus cafezais. ${ }^{38}$ Os salários de algumas localidades aumentaram à medida que a demanda por imigrantes crescia e os fazendeiros tinham que disputar o trabalhador estrangeiro. ${ }^{39}$ Por serem essas ofertas de trabalho públicas, os colonos tinham acesso à informação de salários pagos em diversas localidades e podiam compará-las. Além disso, muitos imigrantes recebiam informações de conhecidos e

\footnotetext{
${ }^{34}$ Hatton e Williamson, "What drove," 534-5; Hatton e Williamson, Age, 14; Timothy J. Hatton e Jeffrey G. Williamson, "International Migration and World Development: A Historical Perspective," NBER Working Papers Series (1992): 10; Timothy J. Hatton e Jeffrey G. Williamson, "What fundamentals drive world migration?," NBER Working Paper 9159 (2002): 9; Timothy J. Hatton e Jeffrey G. Williamson, "International migration in the long-run: positive selection, negative selection and policy," NBER Working Paper 10529 (2004): 21; Simone Wegge, "Occupational Self-selection of European Emigrants: Evidence from Nineteenth-Century Hesse-Cassel," European Review of Economic History 6, n. 3 (2002): 369-70; Witzel de Souza, "From bonded," section 4.2.

${ }^{35}$ Prado, "A imigração no Brasil," 111; Hatton e Williamson, "International migration," 12; Joseph P. Ferrie e Thimothy J. Hatton, "Two centuries of international migration," IZA Discussion Paper n. 7866 (Dec. 2013): 4-5; Wegge, "Chain".

${ }^{36}$ Holloway, Imigrantes, 99-102.

${ }^{37}$ Camargo, Crescimento, 232. Holloway, Imigrantes, 102-4; Denis, Brazil; Petrone, "Imigração," 128.

${ }^{38}$ A Província de São Paulo, 7/4/1888.

${ }^{39}$ Denis, Brazil, 196.
} 
parentes ou as obtinham de experiências anteriores. ${ }^{40}$ Há relatos de que os colonos fossem mais bem informados do que se poderia esperar com relação às condições de trabalho e de vida nas fazendas e teriam os elementos suficientes para decidirem sobre o seu destino no estado de São Paulo. ${ }^{41}$ Por outro lado, autores como Osvaldo Truzzi argumentam que os imigrantes eram levados a assinar os contratos sem terem conhecimento prévio das fazendas onde iriam trabalhar e morar e que os termos do contrato apenas poderiam ser revistos após o término da colheita. ${ }^{42}$

O contrato de trabalho assinado na Agência da Hospedaria do Imigrante consistia em pagamento anual de uma quantia pelo trato de mil pés de café, pagamento pela carpa desses pés e outra soma por alqueire (em geral 50 litros) de café colhido, além do fornecimento de um pedaço de terra para cultivo de gêneros de subsistência. Todos os membros da família do imigrante em idade ativa eram envolvidos no trabalho na fazenda. Como retratado por vários autores, o cultivo de gêneros alimentícios acabou tornando-se um dos principais componentes da renda do colono. $\mathrm{O}$ excedente dessa produção podia ser vendido e representava uma parte essencial da remuneração total do imigrante. A disponibilidade de terras para cultivo próprio das famílias, a fertilidade do solo e sua produtividade tornaram-se determinantes para a localização e preferência dos imigrantes entre as diferentes regiões do estado de São Paulo. ${ }^{43}$ Além disso, a terra para cultivo de subsistência era uma forma dos fazendeiros oferecerem mais incentivos econômicos aos imigrantes sem a necessidade de desembolso de pagamentos em dinheiro. $^{44}$

Cafezais mais velhos, mais fechados e menos produtivos, com terras impróprias para a cultura de alimentos, afugentavam os imigrantes para as fazendas mais novas, geralmente situadas nas regiões de fronteira agrícola, onde a terra era de melhor qualidade e o plantio dos cafezais mais recente. Na região Central e em algumas partes de ocupação mais antiga da Paulista, os cafezais mais antigos tornavam mais difícil intercalar a produção de subsistência com a produção cafeeira, o que fazia os colonos procurarem as áreas mais novas do estado. ${ }^{45}$ Carlos Botelho, secretário da Agricultura entre 1904 e 1908, chegou a afirmar que a expansão cafeeira para o Oeste de São Paulo

\footnotetext{
${ }^{40}$ Denis, Brazil, 197-9.

41 Denis, Brazil, 197.

${ }^{42}$ Oswaldo Truzzi, "Café e indústria no interior de São Paulo (o caso de São Carlos)" (Dissertação de mestrado, Fundação Getúlio Vargas, 1985), 74-8.

${ }^{43}$ Denis, Brazil, 202-3; Petrone, "Imigração," 118-9. Stolcke, Cafeicultura, 44-5.

${ }^{44}$ Petrone, "Imigração," 109-10.

${ }^{45}$ Beiguelman, "A Grande," 149-53.
} 
foi resultado da demanda dos próprios colonos por plantações novas, mais produtivas. ${ }^{46}$ Oswaldo Truzzi e João Pedro Volante afirmam que o deslocamento da fronteira agrícola para o interior do estado decorreu de uma combinação de fatores como a mudança dos investimentos das elites econômicas em busca de melhores terras para o café; a implantação das primeiras levas de imigrantes em zonas já abertas à produção agrícola, acarretando o deslocamento das levas subsequentes para regiões mais distante da capital; e a própria mobilidade geográfica dos colonos, sempre em busca de melhores condições de trabalho e de locais com terras mais baratas onde pudessem se estabelecer como pequenos proprietários. ${ }^{47}$ Como já observado, Pierre Denis, no início do século XX, calculou que entre $40 \%$ a $60 \%$ dos colonos deixavam as fazendas de café ao final das colheitas todos os anos, pelos mesmos motivos. ${ }^{48}$ Em relatório apresentado ao Ministro das Relações Exteriores da Itália sobre as condições da imigração italiana nos anos de 1909 e 1910, B. Belli afirmava que os colonos italianos assalariados destinados a São Paulo estavam em melhores condições econômicas nas áreas de plantações mais recentes. A produtividade dessas áreas seria maior e aos colonos era permitido plantar cereais entre os cafeeiros, o que não ocorria nas plantações mais antigas onde o solo estava exaurido e as plantações de café mais fechadas. Belli inclusive observou que os fazendeiros da região de Campinas, sobrecarregados de dívidas, não estavam arcando com suas obrigações com os colonos, deixando os italianos em situação de miséria. ${ }^{49}$ Os registros na Hospedaria de destinos seguidos pelos imigrantes mostram essa tendência de deslocamento para as regiões de fronteira se consolidando ao longo dos anos. ${ }^{50}$

No final do século XIX, as regiões Central, Mogiana e Paulista predominavam em relação às outras áreas de São Paulo como destino dos imigrantes recém-chegados. O programa da Sociedade Promotora de Imigração de incentivo à vinda de parentes dos imigrantes já estabelecidos na província provavelmente condicionou a localização desses novos imigrantes, que se recusavam a ser direcionados para outras regiões que não as dos então novos cafezais da Mogiana e Paulista. O próprio presidente da

\footnotetext{
${ }^{46}$ Carlos Botelho, "Colonização e limitação da plantação cafeeira," O Correio Paulistano, 21/7/1902.

47 Oswaldo Truzzi e João Pedro Volante, "Percursos migratórios intergeracionais e dinâmicas de implantação de imigrantes estrangeiros no oeste paulista (1880-1950)," Tempo Social 31, n. 3 (2019): 186-7.

${ }^{48}$ Denis, Brazil, 206-7.

${ }^{49}$ B. Belli, "Relatório," Correio Paulistano, 2/7/1911.

${ }^{50}$ Há trabalhos que também mostraram a distribuição dos imigrantes pelo interior do estado. No entanto, por se valerem das estatísticas oficiais, as séries normalmente começam em 1900 e trazem dados apenas agregados, sem diferenciação entre as nacionalidade. Ver, por ex. Camargo, Crescimento, 124-53; Monbeig, Pioneiros, 172-4, 192-5.
} 
província, Rodrigues Alves, em seu relatório de 1888, afirmou que os fazendeiros da região do Vale do Paraíba não eram capazes de oferecer aos imigrantes as vantagens das zonas mais férteis e, por isso, de atraí-los ou mantê-los nas suas fazendas. ${ }^{51}$

Como observado anteriormente, os dados disponíveis de distribuição dos imigrantes pelos diversos municípios de São Paulo não permitiam mapear esse movimento da população durante o início da imigração em massa. A partir dos registros de matrícula da Hospedaria de Imigrantes consolidados para esta tese, é possível ter uma ideia aproximada do deslocamento dos imigrantes entre as localidades do estado de São Paulo na época.

A Tabela 2.1 apresenta a distribuição dos imigrantes para as onze regiões do estado de São Paulo no período de 1886 a 1900. A observação desses dados confirma a concentração dos estrangeiros nas regiões novas da expansão cafeeira. Pela Tabela 2.1 nota-se que onde o café já havia perdido importância em 1886-1900, ou onde a cafeicultura não teve relevância, quase não houve entrada de imigrantes. As regiões de Santos e Litoral Sul, Sorocabana e Baixa Sorocabana receberam juntas pouco mais de 3.000 imigrantes (1,4\% do total). A região do Vale do Paraíba e Litoral Norte, cuja participação na cafeicultura paulista já estava em declínio no final do século XIX, foi destino de apenas 2.438 dos imigrantes (1,2\% do total) que passaram pela Hospedaria naquele período. A região Central, a primeira onde foi utilizada mão de obra imigrante no trabalho nas fazendas, já vinha diversificando sua produção agrícola e perdendo espaço no cultivo do café para as regiões da Mogiana e Paulista, que despontaram no final do século XIX. ${ }^{52}$ Ainda assim, a Central foi o terceiro principal destino no interior do estado, recebendo 34.228 estrangeiros, correspondendo a $16,2 \%$ do total dos imigrantes chegados em São Paulo no período. Já as regiões onde estavam os principais novos centros cafeeiros do estado, Mogiana e Paulista, receberam respectivamente $52.528(24,7 \%)$ e $56.554(26,6 \%)$ imigrantes.

\footnotetext{
${ }^{51}$ São Paulo, Relatório com que o Dr. Francisco de Paula Rodrigues Alves passou a administração da Província de São Paulo ao Dr. Francisco Antônio Dutra Rodrigues, $1^{\circ}$ vice-presidente, no dia 27 de abril de 1888 (São Paulo: Sackler, 1888), 64.

${ }^{52}$ Monbeig, Pioneiros, 167-72.
} 
Tabela 2.1 - Destino dos imigrantes saídos da Hospedaria, por região do estado de São Paulo, 1886-1900

\begin{tabular}{|c|c|c|c|c|c|c|c|c|c|c|c|c|}
\hline Ano & $\begin{array}{c}\text { Alta } \\
\text { Sorocabana }\end{array}$ & Araraquarense & $\begin{array}{c}\text { Baixa } \\
\text { Sorocabana }\end{array}$ & Capital & Central & Mogiana & Noroeste & Paulista & $\begin{array}{c}\text { Santos e } \\
\text { Litoral } \\
\text { Sul }\end{array}$ & Sorocaba & $\begin{array}{c}\text { Vale do } \\
\text { Paraíba e } \\
\text { Litoral Norte }\end{array}$ & $\begin{array}{c}\text { Fora do } \\
\text { Estado }\end{array}$ \\
\hline 1886 & 40 & 29 & 0 & 1.455 & 477 & 885 & $\overline{0}$ & 812 & 32 & 30 & 19 & 5 \\
\hline 1887 & 493 & 542 & 124 & 8.467 & 3.987 & 3.811 & 0 & 5.383 & 252 & 272 & 387 & 28 \\
\hline 1888 & 683 & 622 & 0 & 2.458 & 3.854 & 2.714 & 0 & 3.765 & 43 & 74 & 179 & 75 \\
\hline 1889 & 272 & 279 & 3 & 40 & 899 & 670 & 0 & 767 & 55 & 54 & 29 & 156 \\
\hline 1890 & 1.036 & 888 & 0 & 208 & 1.244 & 2.215 & 0 & 3.927 & 100 & 179 & 33 & 52 \\
\hline 1891 & 655 & 712 & 3 & 5.895 & 4.741 & 3.990 & 0 & 5.459 & 237 & 233 & 528 & 22 \\
\hline 1892 & 688 & 1.136 & 0 & 517 & 2.352 & 3.673 & 0 & 3.101 & 150 & 179 & 263 & 142 \\
\hline 1893 & 0 & 0 & 0 & 421 & 67 & 0 & 0 & 0 & 0 & 0 & 0 & 0 \\
\hline 1894 & 24 & 138 & 0 & 239 & 132 & 339 & 0 & 538 & 5 & 0 & 13 & 0 \\
\hline 1895 & 869 & 851 & 2 & 744 & 1.512 & 2.373 & 0 & 3.175 & 112 & 27 & 116 & 0 \\
\hline 1896 & 376 & 1.022 & 0 & 21 & 1.112 & 1.585 & 0 & 1.842 & 12 & 0 & 55 & 0 \\
\hline 1897 & 2.713 & 4.642 & 327 & 6.597 & 8.138 & 14.071 & 0 & 14.136 & 8 & 145 & 173 & 140 \\
\hline 1898 & 1.524 & 2.741 & 140 & 3.280 & 3.004 & 8.413 & 2 & 6.648 & 0 & 74 & 149 & 71 \\
\hline 1899 & 1.542 & 1.569 & 36 & 2.506 & 1.651 & 3.844 & 97 & 4.448 & 2 & 95 & 241 & 133 \\
\hline 1900 & 2.022 & 1.573 & 11 & 1.077 & 1.058 & 3.945 & 2 & 2.553 & 20 & 63 & 253 & 28 \\
\hline Total & 12.937 & 16.744 & 646 & 33.925 & 34.228 & 52.528 & 101 & 56.554 & 1.028 & 1.425 & 2.438 & 851 \\
\hline
\end{tabular}

Fonte: Registro de Matrícula da Hospedaria de Imigrantes, Memoria do Imigrante, Arquivo Público do Estado de São Paulo. 
Pierre Monbeig sustentou que "enumerar os municípios mais procurados pelos imigrantes seria simplesmente repetir a lista dos centros cafeicultores, na ordem de sua importância". ${ }^{1}$ Realmente, nos últimos anos do século XIX e logo no início do século $\mathrm{XX}$, a corrente imigratória dirigiu-se majoritariamente aos principais núcleos cafeeiros das regiões da Mogiana, Paulista e da Central. Campinas e São Carlos, municípios cafeeiros mais antigos, ainda atraíram a maioria dos imigrantes oriundos da Hospedaria entre 1886 e 1900 no interior do estado (isto é, excluindo-se o município da Capital), tendo recebido respectivamente 14.497 (6,8\% do total) e $13.670(6,4 \%)$ estrangeiros. Esse número pode ser maior, visto serem esses dados relativos aos imigrantes que puderam ser mapeados. No entanto, o crescimento da preferência por municípios de áreas mais novas naquele momento, como Ribeirão Preto, Araraquara e Jaú, que ofereciam melhores remunerações e condições de cultivo, já se mostrava evidente, visto que estas localidades receberam, respectivamente, $10.928(5,1 \%), 6.552(3,1 \%)$ e 6.280 (3\%) imigrantes. A tabela 2.2 abaixo traz os dez principais destinos dos imigrantes saídos da Hospedaria entre 1886 e 1900 e entre 1901 e 1920.

Tabela 2.2 - Dez municípios que mais receberam imigrantes saídos da Hospedaria, São Paulo, 1886-1900

\begin{tabular}{cccc}
\hline Município (Região) & $1886-1900$ & Município & $1901-1920$ \\
\hline Capital (Capital) & 32.970 & Capital (Capital) & 56.028 \\
São Carlos (Paulista) & 14.497 & Ribeirão Preto (Mogiana) & 33.602 \\
Campinas (Central) & 13.670 & Jaú (Araraquarense) & 19.132 \\
Ribeirão Preto (Mogiana) & 10.928 & São Simão (Mogiana) & 16.675 \\
Araraquara (Paulista) & 6.552 & Araraquara (Paulista) & 14.575 \\
Jaú (Araraquarense) & 6.280 & São Carlos (Paulista) & 13.752 \\
Descalvado (Paulista) & 6.147 & Bauru (Noroeste) & 12.965 \\
Rio Claro (Paulista) & 5.910 & Cravinhos (Mogiana) & 12.300 \\
São Simão (Mogiana) & 4.682 & Jaboticabal (Paulista) & 11.745 \\
Amparo (Mogiana) & 4.631 & Campinas (Central) & 10.879
\end{tabular}

Fonte: Registro de Matrícula da Hospedaria de Imigrantes, Memorial do Imigrante, Arquivo Público do Estado de São Paulo.

Notas: Os dados referem-se aos imigrantes mapeados a partir da organização dos mencionados registros de matrícula da Hospedaria de Imigrante. De 1886 a 1900 não foi identificado o destino de 415.796 $(66,2 \%)$ imigrantes registrados na Hospedaria e, de 1901 a 1920, 30.220 (7,2\% do total).

No período de 1901 a 1920 houve realmente uma mudança significativa nos destinos escolhidos pelos que saíram da Hospedaria, como é possível observar na

\footnotetext{
${ }^{1}$ Monbeig, Pioneiros, 171.
} 
Tabela 2.2 acima. Ribeirão Preto, Araraquara e Jaú já superavam os municípios de São Carlos e Campinas na atração de imigrantes. Do total de imigrantes da Hospedaria nesses vinte anos, 41,6\% concentraram-se em apenas dez municípios: São Paulo: Ribeirão Preto, São Simão e Cravinhos (Mogiana), Araraquara, São Carlos e Jaboticabal (Paulista), Campinas (Central), Bauru (Noroeste) e Jaú (Araraquarense). Nos vinte anos entre 1901 e 1920 as novas áreas da expansão cafeeira ganharam destaque. Paralelamente, a Capital, mesmo não tendo peso relevante na agricultura paulista, foi o município que mais recebeu imigrantes no período - aproximadamente 56.000, atraídos pelas oportunidades de trabalho no meio urbano.

Um total de 484.647 migrantes estrangeiros e nacionais registrados na Hospedaria de Imigrantes deslocaram-se para o interior de São Paulo entre 1901 e 1920, conforme pode ser observado na Tabela 2.3 abaixo. As regiões Mogiana, Paulista e Araraquarense receberam juntas 57\% dos que deixaram a Hospedaria entre 1901 e 1920. A Mogiana, maior produtora de café e onde se localizavam as maiores fazendas, foi o destino principal dos que deixavam a Europa em busca oportunidade em São Paulo e atraiu, aproximadamente, 130.000 imigrantes, cerca de $27 \%$ dos quais passaram pela Hospedaria no período mencionado. A maior parte teve como destino Ribeirão Preto, principal município produtor cafeeiro da Mogiana, e que recebeu no período 33.602 imigrantes $(6,2 \%$ do total $)$ - segundo principal destino dos estrangeiros no estado de São Paulo como um todo entre 1901 e 1920, conforme visto na Tabela 2.2. São Simão, o segundo município em importância cafeeira dentro da zona Mogiana, recebeu 16.675 imigrantes (3,1 \% do total). A região da Paulista, por sua vez, recebeu nas duas primeiras décadas do século XX quase 82.000 imigrantes, $16,7 \%$ do total, sendo Araraquara o principal destino da região (14.574 ou 2,6\% do total de imigrantes), seguida por São Carlos (13.752, 2,2\%) e Jaboticabal (11.745, 2,1\%). 
Tabela 2.3 - Destino dos imigrantes saídos da Hospedaria, por região do estado de São Paulo, 1901-1920

\begin{tabular}{|c|c|c|c|c|c|c|c|c|c|c|c|}
\hline Ano & $\begin{array}{c}\text { Alta } \\
\text { Sorocabana } \\
\end{array}$ & Araraquarense & $\begin{array}{c}\text { Baixa } \\
\text { Sorocabana } \\
\end{array}$ & Capital & Central & Mogiana & Noroeste & Paulista & $\begin{array}{c}\text { Santos e } \\
\text { Litoral Sul } \\
\end{array}$ & Sorocaba & $\begin{array}{l}\text { Vale do Paraíba } \\
\text { e litoral Norte }\end{array}$ \\
\hline 1901 & 4.625 & 6.138 & 0 & 3.485 & 3.934 & 14.508 & 0 & 12.283 & 26 & 107 & 355 \\
\hline 1902 & 1.480 & 2.915 & 7 & 1.580 & 2.243 & 8.801 & 0 & 5.496 & 0 & 81 & 94 \\
\hline 1903 & 258 & 406 & 0 & 542 & 408 & 1.157 & 0 & 919 & 0 & 20 & 29 \\
\hline 1904 & 2.137 & 1.253 & 9 & 840 & 1.249 & 4.959 & 0 & 1.622 & 26 & 163 & 53 \\
\hline 1905 & 4.569 & 4.565 & 39 & 2.166 & 2.689 & 10.632 & 542 & 5.477 & 28 & 102 & 96 \\
\hline 1906 & 2.658 & 4.377 & 0 & 2.387 & 3.663 & 9.248 & 306 & 5.520 & 24 & 60 & 53 \\
\hline 1907 & 1.015 & 2.172 & 4 & 1.131 & 1.568 & 3.824 & 213 & 2.451 & 116 & 413 & 47 \\
\hline 1908 & 1.906 & 4.253 & 1.969 & 2.732 & 1.728 & 7.841 & 1.733 & 5.168 & 121 & 1.568 & 121 \\
\hline 1909 & 2.757 & 5.199 & 206 & 1.999 & 2.053 & 8.182 & 3.085 & 5.335 & 849 & 167 & 70 \\
\hline 1910 & 3.809 & 5.103 & 113 & 1.784 & 2.062 & 9.823 & 2.345 & 5.089 & 481 & 261 & 127 \\
\hline 1911 & 7.063 & 6.447 & 220 & 6.382 & 2.882 & 10.619 & 1.588 & 7.204 & 326 & 142 & 185 \\
\hline 1912 & 7.864 & 9.994 & 364 & 14.056 & 4.312 & 15.146 & 1.599 & 9.084 & 743 & 339 & 319 \\
\hline 1913 & 6.222 & 6.232 & 237 & 12.840 & 2.904 & 13.725 & 1.385 & 8.069 & 351 & 309 & 137 \\
\hline 1914 & 555 & 889 & 65 & 2.041 & 310 & 2.026 & 277 & 998 & 218 & 42 & 63 \\
\hline 1915 & 948 & 1.034 & 6 & 679 & 278 & 1.316 & 218 & 771 & 86 & 74 & 5 \\
\hline 1916 & 502 & 598 & 42 & 385 & 186 & 1.085 & 393 & 494 & 57 & 18 & 0 \\
\hline 1917 & 534 & 684 & 16 & 422 & 191 & 1.493 & 190 & 979 & 175 & 3 & 6 \\
\hline 1918 & 758 & 401 & 31 & 68 & 144 & 595 & 290 & 446 & 565 & 74 & 0 \\
\hline 1919 & 1.327 & 459 & 37 & 329 & 62 & 1.123 & 626 & 894 & 438 & 99 & 0 \\
\hline 1920 & 2.540 & 2.567 & 53 & 492 & 157 & 3.471 & 1.471 & 2.825 & 206 & 65 & 18 \\
\hline Total & 53.527 & 65.686 & 3.418 & 56.340 & 33.023 & 129.574 & 16.261 & 81.124 & 4.836 & 4.107 & 1.778 \\
\hline
\end{tabular}


A região Araraquarense figurou como o terceiro principal destino dos imigrantes, recebendo 65.685 estrangeiros $-14,6 \%$ dos que partiram da Hospedaria. A Araraquarense beneficiava-se da proximidade com a Mogiana e a Paulista, além da infraestrutura de transporte ferroviário que a interligava com essas regiões desde o início de sua integração à cafeicultura. $\mathrm{O}$ aumento da área cultivada na Araraquarense entre 1901 e 1920 foi acompanhado por intensa procura de mão de obra, que se traduziu em uma demanda maior por estrangeiros para as fazendas ali localizadas. Jaú foi o quarto município que mais recebeu os imigrantes da Hospedaria nas duas primeiras décadas do século XX e o principal destino dentro da Araraquarense, tendo atraído 22.710 ou $3,4 \%$ do total de imigrantes do período. A Central, cuja importância na agricultura de exportação no começo do século XX já havia declinado, foi o destino de apenas 6,8\% do total dos imigrantes da Hospedaria de Imigrantes entre 1901 e 1920.

As regiões Noroeste e Alta Sorocabana, partes da fronteira agrícola da época, receberam, respectivamente, $11,9 \%$ e 3,6\% dos imigrantes da Hospedaria entre 1901 e 1920. A chegada dos imigrantes a essas regiões ocorreu logo após terem sido ligadas ao restante do estado pela ferrovia. Até 1905, ano em que a linha férrea Noroeste atingiu Bauru, a região Noroeste como um todo havia recebido menos de 100 imigrantes. Nos quinze anos seguintes, conforme novos ramos ferroviários foram sendo construídos e novos municípios criados, a fronteira agrícola avançou e a região passou a receber cada vez mais imigrantes. Apesar de apenas 3,6\% dos imigrantes do período terem se dirigido à Noroeste, Bauru ascendeu ao sétimo principal destino dos imigrantes oriundos da Hospedaria, recebendo no total quase 13.000 estrangeiros $(2,7 \%$ do total do estado de São Paulo) entre 1901 e 1920.

Chama a atenção o fato de Bauru estar entre os municípios que mais atraíram imigrantes por localizar-se em uma região tardiamente ligada ao restante do estado e então sem relevância na produção cafeeira paulista. Como um todo, a região Noroeste foi o destino de 16.261 imigrantes (3,6\% do total), nas duas primeiras décadas do século XX. Municípios da Alta Sorocabana também foram destinos importantes dos imigrantes da Hospedaria. Essa última região recebeu 11,9\% dos que deixaram a Hospedaria, sendo o principal destino dos brasileiros no período. Por ser uma área de fronteira, terras ainda por serem desmatadas e abertas à exploração agrícola eram preferidas pelos nacionais, uma vez que o trabalho de preparação de fazendas não era em geral 
desempenhado pelos imigrantes. ${ }^{1}$ São Manoel, um dos principais produtores cafeeiros da região, recebeu quase 9.300 imigrantes (2\%) entre 1901 e 1920.

Outra forma de avaliar o deslocamento da imigração para a fronteira agrícola do estado de São Paulo no início do século XX é por meio da procura de famílias de colonos pelos fazendeiros paulistas. Os Boletins do Departamento Estadual do Trabalho publicaram entre 1911 e 1915 dados gerais sobre o tema. Nesses cinco anos houve procura por 61.744 famílias pelos fazendeiros junto à Agência de Colocação. ${ }^{2}$ Apenas na zona Mogiana foram procuradas 19.118 famílias (30,9\% de todas as famílias requeridas), seguida pela Paulista com 14.066 (22,7\%) e pela Araraquarense com $11.124(18,0 \%)$. Para a Alta Sorocabana foram pedidas quase 10.000 famílias, cerca de $16 \%$ do total. Essas quatro regiões somaram $67,5 \%$ do total de imigrantes que saíram da Hospedaria entre 1911 e 1915. Os fazendeiros das regiões do Vale do Paraíba e Sorocaba, somadas, procuraram apenas 430 famílias, $0,7 \%$ do total registrado pelos boletins, sendo que nenhum anúncio foi feito por fazendeiros da zona de Santos e Litoral Sul. ${ }^{3}$

A entrada massiva de estrangeiros nessas regiões de fronteira pode ter sido resultado tanto da expansão dos cafezais, da diferença de salários pagos ou por incentivos e promessas de fácil acesso à terra. Haver entre os principais destinos dos imigrantes municípios que se encontravam em zonas de fronteira, distantes da capital, indica a preferência dos estrangeiros por locais onde a produção cafeeira estava no seu auge. O fato aponta, também, para a grande mobilidade dos estrangeiros nesse período.

\subsubsection{As nacionalidades}

Do ponto de vista dos países europeus e de sua população emigrante, os portugueses eram os que mais buscavam o Brasil na hora de decidirem para onde emigrar. Os laços culturais, a língua em comum, a emigração de longa data para o país e as redes de conterrâneos já estabelecidos são alguns dos fatores de atração apresentados

\footnotetext{
${ }^{1}$ Monbeig, Pioneiros, 174.

2 Os fazendeiros podiam procurar junto à Agência Oficial de Colocação famílias de colonos para trabalharem em suas fazendas. Junto ao pedido que enviavam, informavam a quantidade de famílias que necessitavam e a remuneração paga pelo trato anual de 1000 cafeeiros, pela carpa avulsa de 1000 cafeeiros e pela colheita por alqueire (correspondente a 50 litros de café). Os fazendeiros podiam submeter à Agência, também, as chamadas de imigrantes feitas por colonos localizados em suas terras. Essa prática, como visto no capítulo anterior, foi muito incentivada nos anos 1890 pela Sociedade Promotora de Imigração.

${ }^{3}$ Boletim do Departamento Estadual do Trabalho, diversos anos.
} 
pela literatura para justificar a preferência dominante portuguesa pelo Brasil. ${ }^{4}$ Entre 1886 e 1900, 55.487 portugueses passaram pela Hospedaria de São Paulo. De 1901 a 1920 foram quase 72.000. ${ }^{5}$ Diferentemente dos italianos e espanhóis, os portugueses tendiam mais ao trabalho urbano e à localização na zona urbana dos municípios. Os que passaram pela Hospedaria buscaram, nos dois períodos analisados, a região da Capital como principal destino (28,8\% entre 1886 e 1900 e 32,0\% entre 1901 e 1920). ${ }^{6}$ A Mogiana veio em seguida, sendo destino de $25,5 \%$ dos portugueses no primeiro período e $22,7 \%$ no segundo. Poucos portugueses se aventuraram nas regiões de fronteira. $\mathrm{O}$ Anexo A2.2 traz a distribuição de portugueses pelas regiões do estado de São Paulo nos dois períodos estudados.

Do final dos anos 1880 até o começo do século XX, São Paulo foi o principal destino dos imigrantes italianos, à frente mesmo da Argentina e dos Estados Unidos. ${ }^{7}$ Os italianos foram o principal grupo de imigrantes em trânsito pela Hospedaria: 456.000 entre 1886 e 1901 e 150.000 dali até 1920. No primeiro momento, a maioria dos encaminhados pela Hospedaria seguiu para a região da Paulista $(28,0 \%)$ e Mogiana $(24,5 \%)$, tendo a Central e a Capital recebido respectivamente $16,9 \%$ e $14,5 \%$. No período seguinte, a Mogiana ganhou destaque e recebeu 32,1\% do fluxo de italianos. A Paulista vem em seguida com $23,1 \%$ e a Araraquarense $15,7 \%$ - o dobro do período anterior. Os italianos não tenderam a deixar as regiões onde o café já se consolidara em detrimento das áreas de fronteiras onde o café começava a se expandir, como fizeram os espanhóis, como será visto a seguir. A distribuição detalhada dos italianos pelo estado de São Paulo nos dois períodos é apresentada no Anexo A2.3.

A imigração espanhola começou mais tardiamente, ganhando volume no início do século XX para suprir a demanda por mão de obra nas fazendas, especialmente nas áreas recém-abertas ao café que não estavam mais sendo atendidas pelo fluxo de italianos, diminuído após a proibição na Itália da imigração subsidiada para São Paulo

\footnotetext{
${ }^{4}$ Herbert S. Klein, "A integração social e econômica dos portugueses no Brasil nos finais do século XIX e no século XX," Análise Social 121, n. 2 (1993): 242. Sobre os portugueses no interior de São Paulo, ver também o trabalho recente de Maria Izilda Santos de Matos e Oswaldo Truzzi, "Colonização e fronteiras: portugueses, presença, trabalho e lutas nos interiores de São Paulo," História 39, Dossiê História da Colonização em Terras Paulistas: Dinâmicas e Transformações (Séculos XVI a XX) (2020).

${ }^{5}$ Cerca de $80 \%$ de todos os portugueses que deixaram Portugal vieram para o Brasil. Klein, "A Integração," 237-8.

${ }^{6}$ A legislação baixada em 1906 mudava o entendimento de quais imigrantes tinham direito à passagem paga e alojamento na Hospedaria, incluindo aqueles em família ou solteiros e os que buscavam se colocar no estado como agricultores, jornaleiros, operários ou artistas. Ver: São Paulo, Lei no $1.045-\mathrm{C}$ de 27 de dezembro de 1906.

${ }^{7}$ Hutter, Imigração, 70; Herbert Klein, “A Integração dos Imigrantes Italianos,” 96.
} 
em 1902. ${ }^{8}$ Até 1900 a Hospedaria recebeu 77.000 espanhóis, enquanto de 1901 a 1920 foram 167.000 dessa nacionalidade. De acordo com os dados encontrados, logo no primeiro momento os espanhóis tenderam mais a se dirigir para a fronteira do que os portugueses ou italianos, acompanhando a expansão do café, corroborando o que já foi dito pela literatura. ${ }^{9}$ Entre 1886 e 1900, 9,2\% dos espanhóis se deslocaram para a Alta Sorocabana e 11,6\% para a Araraquarense. De 1901 a 1920, os percentuais foram $11,2 \%$ e $17,5 \%$, respectivamente. Nos dois períodos os números são superiores aos de outras nacionalidades. O efeito de atração dos cafezais também é inegável: 24,1\% dos espanhóis da Hospedaria no primeiro período e $27,7 \%$ no segundo foram para a região da Mogiana, contra 8,7\% e 15,7\% no caso dos italianos, respectivamente. Para a Paulista, dirigiram-se $21,5 \%$ dos espanhóis no primeiro período, diminuindo para $16,8 \%$ no segundo. ${ }^{10}$ Mais uma vez diferindo dos italianos, os espanhóis, como os portugueses, mantiveram seu fluxo para a Capital, tendo $15,1 \%$ para lá se dirigido entre 1886 e 1900 e $12,7 \%$ no período subsequente. ${ }^{11} \mathrm{O}$ deslocamento detalhado dos espanhóis pelas regiões paulistas é apresentado no Anexo A2.4.

Quando se observa o fluxo de alemães para as regiões do estado de São Paulo de 1886 a 1920, o que se constata é sua presença predominante nas zonas da Capital e Paulista. Ambas as regiões atraíram, respectivamente, cerca de $30,6 \%$ e de $17,8 \%$ dos alemães da Hospedaria entre 1886 e 1900 e 21,4\% e 21,6\% entre 1901 e 1920. Essa preferência ao longo de todo o período para tais regiões, já conhecidas dos alemães desde as primeiras experiências com o trabalho imigrante na década de 1840, veio se somar ao que foi sugerido anteriormente sobre o efeito prévio do estoque de imigrantes na atração de novas levas de conterrâneos. Curiosamente, o fluxo de alemães em trânsito na Hospedaria e dirigidos à Mogiana diminuiu de 14,5\% entre 1886 e 1900 para

\footnotetext{
${ }^{8}$ Alfredo Ellis Jr, Populações Paulistas (São Paulo: ED. Nacional, 1934); José de Souza Martins, “A imigração espanhola para o Brasil e a formação da força-de-trabalho na economia cafeeira: 1880-1930," Revista de História 121 (ago./dez. 1989): 8-10.

9 Souza Martins, “A imigração," 22; Maria S. Bassanezi et al, Atlas da imigração internacional em São Paulo, 1850-1950 (São Paulo: UNESP, 2008), 52.

${ }^{10}$ João Paulo da Silva, em trabalho recente, lista 34 municípios no estado de São Paulo com presença de espanhóis em suas populações. Com exceção de Piracicaba, localizada na zona Central, Ribeirão Preto e Franca, localizados na Mogiana, o restante estava em áreas de fronteira da Araraquarense e Noroeste. Alguns, como Pirajuí, chegaram a ter $23 \%$ da população composta por imigrantes espanhóis. João Paulo da Silva, "Espanhóis no interior de São Paulo: múltiplas possibilidades de incorporação" (Tese de doutorado, UFSCAR, 2020), 30-2.

${ }^{11}$ A presença dos espanhóis na Capital foi bem estudada em Laura A. Maciel e Maria A. M. Antonacci, “Espanhóis em São Paulo: modos de vida e experiências de associação,” Projeto História 12 (Out. 1995); João L. Nascimento, "Trabalho e prestígio social: os espanhóis em São Paulo," in História econômica da Primeira República, orgs. Sergio Silva e Tamás Szmrecsányi (São Paulo: Edusp/Imprensa Oficial/Hucitec, 2002).
} 
10,7\% entre 1901 e 1920, enquanto a Araraquarense passou a ser um destino mais atrativo aos alemães. A entrada de alemães nessa última região aumentou de $10,9 \%$ entre 1886 e 1900 para 11,5\% entre 1901 e 1920. Esses dados são apresentados em detalhe no Anexo A2.5.

Dentre os imigrantes de outras nacionalidades, os destinos principais não foram os centros cafeeiros do estado. Os suecos, por exemplo, não tiveram uma tendência de fixação em regiões específicas. Dos entrados entre 1886 e 1900, 31\% foram para a Capital e $61 \%$ para a Central. No período seguinte, $35 \%$ dos suecos tiveram a Alta Sorocabana como destino, 32\% ficaram na Capital e 27\% escolheram a Mogiana. ${ }^{12}$ Já os sírios, cuja entrada na Hospedaria começou em 1900, dirigiram-se majoritariamente para as regiões de fronteira: 55\% destes escolheram a Araraquarense e a Noroeste. Os austríacos tenderam a permanecer concentrados na Paulista e na Mogiana, sem grande presença nas áreas de fronteira. Para os austríacos, chama a atenção os fluxos terem permanecido praticamente inalterados na comparação dos dois períodos, com $32 \%$ dessa nacionalidade encaminhados para a Paulista e $22 \%$ para a Mogiana. A única mudança significativa foi em direção à Central, que entre 1886 e 1900 recebeu $17 \%$ do fluxo e no período seguinte apenas $7 \%$ dos austríacos.

Ainda que não seja possível assegurar com absoluta certeza que a presença prévia de imigrantes influenciou novos fluxos migratórios, a descrição da distribuição das diversas nacionalidades pelas regiões do estado sugere alguma correlação. Por mais que novas oportunidades tenham atraído e deslocado o fluxo migratório para as regiões de fronteira nas duas primeiras décadas do século $\mathrm{XX}$, as nacionalidades que tradicionalmente se concentravam em determinadas regiões desde o começo da imigração subsidiada ou mesmo anteriormente a ela parecem ter tendido a continuar nessas regiões. É o caso dos portugueses na região da Capital, dos espanhóis nas regiões de fronteira, e dos italianos na Mogiana e Paulista. A presença prévia de conterrâneos parece ter influenciado a chegada de mais imigrantes da mesma nacionalidade, em sintonia com o que afirma a literatura para outros países. Estudos mais aprofundados levando em conta a origem na terra natal e o destino escolhido em São Paulo poderão confirmar a prevalência do efeito da chain migration.

\footnotetext{
${ }^{12}$ Sobre a imigração sueca para o Brasil e para São Paulo, ver: Dag Retsö, "Emigration from the Nordic countries to Brazil 1880-1914," Iberoamericana - Nordic Journal of Latin American and Caribbean Studies 45, n. 1 (2016).
} 


\section{Conclusões}

Este capítulo reconstituiu, incialmente, a distribuição de imigrantes pelos municípios e regiões do estado de São Paulo para os períodos entre 1886-1900 e 19011920 buscando suprir uma lacuna existente na historiografia da imigração para São Paulo. Os dados oficiais divulgados nos Anuários Estatísticos, nas Mensagens de Presidentes de Província/Estado e nos Relatórios da Secretaria da Agricultura reuniram de forma desagregada informações de alguns poucos anos da década de 1890 e, de forma um pouco mais sistemática, das duas primeiras décadas do século XIX, não permitindo estudar o movimento dos estrangeiros em São Paulo no início da imigração em massa. A partir da limpeza e sistematização de uma base de dados original contendo mais de 1,5 milhão de registros de matrícula de estrangeiros da Hospedaria de Imigrantes, traçou-se neste capítulo um panorama detalhado do movimento imigratório de 1886, nos primórdios do programa de subsídios implantado pelo governo de São Paulo, até 1920.

A localização dos imigrantes oriundos da Hospedaria passou por mudanças substanciais no período analisado. Dividindo a análise dos dados em dois períodos, de 1886 a 1900 e 1901 a 1920, nota-se que a imigração teve como destino principal as fazendas dos municípios cafeeiros e acompanhou o deslocamento da fronteira agrícola, conforme o café avançava para as regiões recém integradas ao restante do estado por meio das ferrovias. Alguns municípios predominaram na atração de imigrantes, principalmente nas regiões da Mogiana e da Paulista, como Ribeirão Preto, Batatais, Franca, Araraquara e Jaboticabal, onde era grande a demanda de colonos para as fazendas e para substituir os que partiam em busca de novas oportunidades na fronteira agrícola. Principalmente no segundo período, de 1901 a 1920, as regiões da Alta Sorocabana, Araraquarense e Noroeste, onde nas manchas de terra roxa e no solo arenítico o café estava se expandindo, a diferença de salários pagos ou por incentivos e promessas de fácil acesso à terra exerciam atração tanto sobre os novos estrangeiros que chegavam ao estado de São Paulo quanto os que já residiam e que buscavam melhores oportunidades de trabalho e de adquirirem terras. $\mathrm{O}$ fato dos principais destinos dos imigrantes terem sido municípios que se encontravam em zonas de fronteira, distantes da capital, indica a preferência dos estrangeiros por locais onde a produção cafeeira estava no seu auge. As comparações dos fluxos migratórios entre os períodos de 1886 a 1900 e 1901 a 1920 permitiram verificar um fato levantado pela literatura sobre 
imigração em outros países: a influência de uma concentração prévia de imigrantes na atração de conterrâneos para o mesmo destino. A distribuição dos imigrantes nas diversas regiões do estado ao longo do tempo confirmou a tendência de concentração de algumas nacionalidades em determinadas regiões e também o deslocamento da onda migratória em direção à fronteira agrícola de São Paulo conforme se iniciava o século XX.

A presença crescente de imigrantes nas diferentes zonas do estado se traduziu também em uma maior participação como proprietários de terras. No próximo capítulo serão analisadas as propriedades rurais dos estrangeiros, buscando identificar suas particularidades em relação ao restante dos estabelecimentos rurais de São Paulo. 


\section{CAPÍTULO 3 - AS PROPRIEDADES DOS ESTRANGEIROS EM SÃO PAULO, 1905-1920}

A partir da segunda metade do século XIX, a expansão ferroviária permitiu a integração econômica e exploração geográfica de uma ampla parte do estado de São Paulo. As ferrovias permitiram igualmente a ampliação da fronteira agrícola para o interior cada vez mais distante da capital, incorporando terras virgens de alta qualidade e ampliando a zona produtora de café. Pelos mesmos trilhos por onde se escoava a produção cafeeira rumo ao porto de Santos e dali para o mundo, milhares de imigrantes eram levados ao interior do estado para o trabalho nas fazendas.

Como visto no Capítulo 1, durante o período da imigração em massa para São Paulo o acesso à terra para os imigrantes enquanto política pública aconteceu apenas porque a venda de lotes tornou-se complementar aos interesses da elite cafeicultora. Mesmo havendo projetos de estabelecimento de imigrantes em núcleos coloniais desde o século XIX, a política muitas vezes fracassou ou ficou aquém dos objetivos, seja pela localização dos núcleos, distantes dos centros urbanos e das ferrovias, seja pela presença mais de nacionais que de estrangeiros entre os compradores dos lotes. Em vez de pequenos proprietários, a política imigratória prioritária adotada pelo governo em conjunto com os cafeicultores visava a atração de famílias de estrangeiros pobres para o trabalho nas fazendas. Apesar dessa política imigrantista que priorizara os interesses das grandes propriedades, os estrangeiros conseguiram se tornar proprietários de terra em São Paulo em número expressivo.

Este capítulo analisa as propriedades rurais pertencentes aos estrangeiros conforme foram listadas nas estatísticas oficiais das primeiras duas décadas do século XX. A literatura já reconheceu a presença dos imigrantes no quadro de donos de terra do estado. ${ }^{1}$ Conforme a Estatística Agrícola de 1905, $15 \%$ das propriedades rurais do estado de São Paulo naquele ano estavam em mãos de proprietários estrangeiros. Em 1920 os estrangeiros eram donos de quase $28 \%$ das propriedades rurais do estado. No entanto, apesar dos trabalhos fundamentais sobre a imigração europeia, há ainda vários aspectos das propriedades adquiridas por imigrantes que precisam ser melhor

\footnotetext{
${ }^{1}$ Por exemplo, Holloway, Imigrantes, cap. 6.
} 
conhecidos. ${ }^{2}$ Este capítulo busca responder um conjunto de questões específicas e importantes: quais nacionalidades predominavam entre os estrangeiros proprietários? Em quais regiões do estado de São Paulo estavam concentradas as propriedades dos imigrantes? Qual o tamanho dessas propriedades? Qual a combinação de culturas agrícolas nelas adotada?

Para responder essas questões serão utilizadas duas fontes principais: a Estatística Agrícola realizada pela Secretaria da Agricultura de São Paulo entre 1904 e 1905 e que traz informações detalhadas de mais de 49.000 propriedades rurais; e o Censo Agrícola do Recenseamento Geral do Brasil de 1920, com informações para 80.000 propriedades rurais. Inicialmente, apresenta-se um panorama da agricultura no estado de São Paulo no início do século XX. Em seguida, são analisadas as características das propriedades agrícolas pertencentes aos estrangeiros no estado registradas nas duas fontes mencionadas.

\subsection{A agricultura paulista no começo do século XX: um breve panorama}

Para analisar as propriedades de terras em posse de estrangeiros, serão utilizados os dois principais levantamentos estatísticos feitos pelos governos estadual e federal no período: a Estatística Agrícola e Zootécnica elaborada pela Secretaria de Agricultura do estado no ano agrícola de 1904-1905 e o Recenseamento Geral do Brasil de $1920 .^{3}$ Em 1905, em meio à crise da superprodução do café, o governo estadual decidiu realizar uma análise completa da situação rural da província. Carlos Botelho, então secretário estadual da Agricultura, justificou, em seu relatório de 1906, a necessidade do levantamento minucioso, visto como indispensável para que fosse possível adotar novas medidas de auxílio à fazenda cafeeira. ${ }^{4} \mathrm{O}$ resultado foi um censo agrícola sem precedentes no Brasil em termos de escopo e tamanho, abrangendo todos os 171 municípios existentes no estado à época. ${ }^{5}$

\footnotetext{
2 Dentre a literatura clássica sobre imigração e terras, ver: Denis, Brazil; Beiguelman “A Grande,” 155-7; Hall, "Origins," 180-3; Dean, Rio Claro, 177-82; Dean, “A pequena propriedade”; Petrone, Imigrantes; Holloway, Imigrantes, cap. 6;

3 Será utilizada aqui a edição crítica da Estatística Agrícola e Zootécnica produzida por Maria S.C. Bassanezi e Priscila M. S. Francisco, Estado de São Paulo: Estatística agrícola e zootécnica, 1904-1905 [CD-ROM] (Campinas: Nepo/Unicamp, 2003).

${ }^{4}$ São Paulo, Relatório... Dr. Carlos Botelho anno de 1906, 46-7.

${ }^{5}$ Os resultados do levantamento foram publicados em fascículos individuais para cada um dos municípios nos três anos seguintes e de forma agregada no Relatório da Secretaria da Agricultura de 1906. Para seis
} 
Vale notar que outros levantamentos estatísticos foram realizados em anos anteriores e apresentados nos Anuários Estatísticos do Estado de São Paulo. No entanto, tais levantamentos foram muito menos detalhados que o de 1904-5. Por exemplo, nenhum dos levantamentos anteriores apresenta dados sobre propriedades de estrangeiros e foi comum não incluírem informações de vários municípios. É o caso de um trabalho publicado no Anuário Estatístico de São Paulo de 1900, que trouxe dados para apenas 101 dos 172 municípios, registrando 68.061 estabelecimentos rurais e apresentando a região da Alta Sorocabana como a maior produtora de café do estado de São Paulo. ${ }^{6}$ Os números de estabelecimentos rurais publicados são discrepantes com os dados produzidos cinco anos mais tarde, enquanto o fato da Alta Sorocabana aparecer como maior produtora de café em 1900 claramente resultou das informações incompletas de vários municípios das outras regiões. ${ }^{7}$ Em 1905, por ocasião do censo mais detalhado e completo, a Alta Sorocabana aparecia em quinto lugar no estado em produção cafeeira, com um total de 3,9 milhões de arrobas, atrás da Mogiana (12,2 milhões de arrobas), Paulista (7,6 milhões), Araraquarense (5,7 milhões) e Central (4,4 milhões). ${ }^{8}$

Ao apresentar-se o panorama geral da agricultura paulista e das propriedades rurais dos estrangeiros em 1905, serão utilizados os dados agregados dos 171 municípios. Para o estudo das propriedades agrícolas dos imigrantes, por sua vez, utilizam-se dados desagregados dos 165 municípios que tiveram os resultados das estatísticas publicadas em fascículos, por constarem as informações individuais de cada propriedade. Os 171 municípios compreendiam 57.211 propriedades agrícolas. Já os 165 municípios, excluindo os seis que não tiveram seus dados apresentados nos fascículos, somavam 49.272 propriedades rurais. $^{9}$

municípios ou a publicação em fascículos não ocorreu ou estas se perderam. São estes os municípios: Mogi das Cruzes, Santa Izabel (Vale do Paraíba e Litoral Norte), Tietê (Alta Sorocabana); Itú (Central); Apiaí (Baixa Sorocabana); e Iguape (Santos e Litoral Sul). Os dados agregados para estes municípios, no entanto, foram publicados no referido relatório de 1906. São Paulo, Relatório... Dr. Carlos Botelho anno de 1906.

${ }^{6}$ São Paulo, Relatório do anno de 1900 apresentado em 13 de janeiro de 1902 ao cidadão Dr. Bento Pereira Bueno, Secretário de Estado dos Negócios do Interior e da Justiça, pelo Dr. Antonio de Toledo Piza, Director (São Paulo: Typ do Diario Official, 1903), 546-53.

7 Esse equívoco foi cometido por Francisco Vidal Luna e Herbert Klein em trabalho recente sobre o estado de São Paulo. Francisco Vidal Luna e Herbert S. Klein, An economic and demographic history of São Paulo, 1850-1950 (Stanford: Stanford University Press, 2018), 97.

${ }^{8}$ São Paulo, Estatística Agrícola de 1905.

${ }^{9}$ São Paulo, Estatística Agrícola de 1905; São Paulo, Relatório 1906. 
O Recenseamento Geral do Brasil de 1920, por sua vez, registra os estabelecimentos rurais agregados por municípios, sem distinção da nacionalidade específica dos proprietários, separando-os apenas em nacionais e estrangeiros. Os dados dos municípios incluem número de propriedades, área total e cultivada e quantidade produzida de cada gênero no ano agrícola de 1919-1920. Apenas em uma tabela geral dos estabelecimentos rurais do estado de São Paulo são apresentadas informações agregadas sobre as propriedades pertencentes a diversas nacionalidades, o que permite comparações com a Estatística Agrícola de 1905.

É possível esboçar a evolução da agricultura paulista no começo do século XX comparando as estatísticas de 1905 e 1920, embora o exercício possa ser parcialmente comprometido devido às eventuais diferenças de cobertura e precisão entre os dois levantamentos. Por exemplo, o número de propriedades rurais no estado de São Paulo aparece como tendo aumentado 42\% entre 1905 e 1920. É possível que parte desse crescimento esteja superestimado devido a um eventual sub-registro de propriedades em 1905. ${ }^{10}$ As comparações, portanto, entre os dois levantamentos estatísticos devem ser vistas com cautela.

Levando em conta as figuras disponíveis, o crescimento de $42 \%$ no número de estabelecimentos entre 1905 e 1920 não foi uniforme entre as regiões. Quando observadas as regiões mais antigas, como a da Capital, do Vale do Paraíba, Central e Baixa Sorocabana, o número de propriedades diminuiu no período, indicando a consolidação das propriedades existentes e um possível deslocamento de proprietários para as áreas de fronteira, como a Alta Sorocabana, Araraquarense e Noroeste que, nesses 15 anos, viram o número de propriedades rurais em seus territórios aumentar consideravelmente. A Tabela 3.1 abaixo apresenta o total de municípios e de propriedades rurais em cada região do estado de São Paulo em 1905 e 1920.

\footnotetext{
10 Apesar das instruções para o recenseamento, ditadas pelo Decreto n. 1.323 de 23 de outubro de 1905, preverem que na ausência ou recusa de um proprietário em preencher os questionários os auxiliares deveriam obter as informações com vizinhos ou conhecido, parece plausível a ideia da cautela e de possível subestimação no levantamento.
} 
Tabela 3.1 - Regiões, municípios e propriedades rurais, estado de São Paulo, 1905 e 1920

\begin{tabular}{ccccc}
\hline Região & $\begin{array}{c}\text { Municípios em } \\
1905\end{array}$ & $\begin{array}{c}\text { Propriedades } \\
\text { em 1905 }\end{array}$ & $\begin{array}{c}\text { Municípios em } \\
1920\end{array}$ & $\begin{array}{c}\text { Propriedades em } \\
1920\end{array}$ \\
\hline Capital & 7 & 2.524 & 7 & 2.262 \\
Vale do Paraíba e Litoral Norte & 37 & 14.252 & 37 & 11.263 \\
Sorocaba & 13 & 2.570 & 13 & 6.784 \\
Central & 19 & 7.680 & 19 & 7.366 \\
Mogiana & 27 & 8.086 & 31 & 10.966 \\
Paulista & 17 & 4.563 & 21 & 8.277 \\
Araraquarense & 16 & 5.596 & 24 & 14.360 \\
Noroeste & 1 & 341 & 6 & 3.351 \\
Alta Sorocabana & 17 & 5.060 & 28 & 9.844 \\
Baixa Sorocabana & 12 & 4.097 & 13 & 3.836 \\
Santos e Litoral Sul & 5 & 2.442 & 5 & 2.610 \\
\hline Total & 171 & 57.211 & 204 & 80.921 \\
\hline
\end{tabular}

Fonte: São Paulo, Estatística Agrícola 1905; Brasil, Ministério da Agricultura. Industria e Commercio. Directoria Geral de Estatística, Recenseamento do Brazil realizado em 1 de Setembro de 1920 (Rio de Janeiro: Typ. Da Estatística. 1923): v. III. 1a parte.

Pela Tabela 3.1, observa-se que na região Noroeste o número de propriedades rurais aumentou dez vezes entre 1905 e 1920. Na Araraquarense e na Sorocaba esse aumento foi da ordem de duas vezes e meia. Nas maiores produtoras de café, Mogiana e Paulista, o aumento foi de 1,4 e 1,8 vezes, respectivamente.

Outro aspecto da evolução das propriedades rurais paulistas entre 1905 e 1920 diz respeito ao tamanho dessas unidades produtivas. Para que seja possível estudá-las, utiliza-se aqui a classificação adotada por Milliet (modificada de Caio Prado Jr) para a divisão dos estabelecimentos rurais de acordo com o tamanho (pequenas, médias, grandes propriedades e latifúndios). As pequenas propriedades são as que possuem até 25 alqueires; as médias possuem entre 25,01 e 100 alqueires; as grandes propriedades são as de 100,01 a 500 alqueires, e os latifúndios mais de 500 alqueires. Ainda que arbitrária, essa classificação permite uniformizar as informações das propriedades rurais, tornando possível a comparação entre regiões do estado. ${ }^{11}$ De acordo com os dois recenseamentos consultados, a área total abrangida pelas propriedades rurais do estado aumentou em 11,5\%, passando de 5.077.820 alqueires em 1905 para 5.736.889 alqueires em 1920, como pode ser visto na Tabela 3.2 abaixo.

\footnotetext{
${ }^{11}$ Milliet, “O desenvolvimento,” 70; Prado Jr., “Distribuição da propriedade,” 639.
} 
Tabela 3.2 - Áreas total e média das propriedades rurais por regiões do estado de São Paulo, em 1905 e 1920 , em alqueires

\begin{tabular}{ccccc}
\hline \multirow{2}{*}{ Região } & \multicolumn{2}{c}{1905} & \multicolumn{2}{c}{1920} \\
& Área total & Área média & Área total & Área média \\
\hline Capital & $82.909,90$ & 32,8 & $56.272,73$ & 24,8 \\
Vale do Paraíba e Litoral Norte & $592.777,52$ & 41,6 & $476.749,59$ & 42,3 \\
Sorocaba & $280.214,80$ & 109,1 & $259.726,86$ & 38,9 \\
Central & $436.721,25$ & 56,8 & $342.151,24$ & 46,4 \\
Mogiana & $843.910,00$ & 104,4 & $887.670,66$ & 80,9 \\
Paulista & $569.885,75$ & 124,19 & $694.381,40$ & 83,9 \\
Araraquarense & $592.907,53$ & 105,9 & $932.910,33$ & 64,9 \\
Noroeste & $220.777,00$ & 647,4 & $327.938,02$ & 97,8 \\
Alta Sorocabana & $709.592,86$ & 140,2 & $1.023 .011,57$ & 103,9 \\
Baixa Sorocabana & $520.058,68$ & 126,9 & $488.655,37$ & 126,7 \\
Santos e Litoral Sul & $228.064,88$ & 93,4 & $176.119,83$ & 67,9 \\
\hline Total Geral & $5.077 .820,15$ & 88,7 & $5.736 .888,60$ & 70,0 \\
\hline
\end{tabular}

Fonte: São Paulo, Estatística Agrícola, 1905; Brasil, Recenseamento 1920.

Em relação à área média das propriedades, pela Tabela 3.3 abaixo vê-se que, com exceção do Vale do Paraíba que apresentou um discreto aumento, todas as demais zonas apresentaram diminuição no tamanho médio das propriedades rurais. A maior diminuição observada foi na zona Noroeste, cujas propriedades passaram de um tamanho médio de 647 alqueires, em 1905, para 97 alqueires em 1920. Na Mogiana e Paulista o tamanho das propriedades diminuiu em média 30\%, passando de 104,4 alqueires em 1905 para 80,9 em 1920.

Pela Tabela 3.3, observa-se que, em 1905, uma área de 613.567 alqueires, pouco mais de $12 \%$ da área total ocupada pelos estabelecimentos rurais, estava sob cultivo. Em 1920, a área cultivada havia se ampliado em mais de um terço, alcançando 827.085 alqueires, mas representando apenas $14,4 \%$ da área ocupada do estado. Pode-se notar que o aumento da área cultivada não foi igual em todas as regiões do estado de São Paulo. Na Central, a área cultivada em relação à área total dos estabelecimentos rurais aumentou de 22,3\% em 1905 para 24,3\% em 1920. Na Araraquarense esse percentual era de 13,2\% em 1905 passando para 18,9\% em 1920. Na Alta Sorocabana 7,1\% da área dos estabelecimentos rurais estavam em cultivo, crescendo para 8,1\% em 1920. Apenas a Mogiana e a Noroeste apresentaram um aumento considerável do uso da terra das propriedades agrícolas no período. A Noroeste foi a região que apresentou o maior crescimento da área cultivada no período, passando de apenas 1\% em 1905 para 14\% 
em 1920. Em seguida vinha a Mogiana, passando de 17,4\% de área cultivada em 1905 para $22,5 \%$ em 1920.

Tabela 3.3 - Área cultivada das propriedades rurais do estado de São Paulo, em 1905 e 1920, em alqueires e em porcentagem

\begin{tabular}{ccccc}
\hline Região & $\begin{array}{c}\text { Área cultivada } \\
\text { em 1905 }\end{array}$ & $\begin{array}{c}\text { Porcentagem da área } \\
\text { cultivada sobre a área } \\
\text { total em 1905 }\end{array}$ & $\begin{array}{c}\text { Área cultivada } \\
\text { em 1920 }\end{array}$ & $\begin{array}{c}\text { Porcentagem da área } \\
\text { cultivada sobre a área } \\
\text { total em 1920 }\end{array}$ \\
\hline $\begin{array}{c}\text { Capital } \\
\text { Vale do Paraíba e }\end{array}$ & $6.512,65$ & 7,9 & $2.780,6$ & 4,9 \\
Litoral Norte & $82.552,19$ & 13,9 & $50.849,6$ & 10,7 \\
Sorocaba & $16.636,66$ & 5,9 & $19.849,2$ & 7,6 \\
Central & $97.465,88$ & 22,3 & $83.157,9$ & 24,3 \\
Mogiana & $146.110,02$ & 17,3 & $200.012,0$ & 22,5 \\
Paulista & $94.956,75$ & 16,7 & $131.328,1$ & 18,9 \\
Araraquarense & $78.327,70$ & 13,2 & $176.734,3$ & 18,9 \\
Noroeste & $2.558,50$ & 1,2 & $45.529,3$ & 13,9 \\
Alta Sorocabana & $50.631,52$ & 7,1 & $89.416,5$ & 8,7 \\
Baixa Sorocabana & $27.821,93$ & 5,3 & $21.619,4$ & 4,4 \\
Santos & $9.993,25$ & 4,4 & $5.807,9$ & 3,3 \\
\hline Total Geral & $613.567,03$ & 12,1 & $827.084,7$ & 14,4 \\
\hline
\end{tabular}

Fonte: São Paulo, Estatística Agrícola, 1905; Brasil, Recenseamento 1920.

Segundo a Estatística Agrícola de 1905, quase 60\% da área cultivada estavam dedicados ao cultivo do principal produto de exportação, o café. A produção cafeeira total do estado naquele ano foi de 36,3 milhões de arrobas, concentrada em quatro regiões que juntas produziram 95\% do total. A região Mogiana foi responsável naquele ano por 12,3 milhões de arrobas, seguida pela Paulista com 7,7 milhões, a Araraquarense com 5,7 milhões e a Central com 4,7 milhões. Gêneros alimentícios ocupavam 43,5\% dos alqueires cultivados, com o milho sendo o mais expressivo, representando $26 \%$ da área plantada, seguido pelo feijão, com 10,0\% e o arroz, com 4\%. ${ }^{12}$ Em 1920, o café perdeu espaço, com 52\% da área cultivada dedicada ao seu cultivo. Cerca de $90 \%$ da produção continuava concentrada nas mesmas regiões que em 1905; no entanto, as mais antigas, como a Central, vinham perdendo espaço para as regiões de fronteira da Araraquarense, Alta Sorocabana e Noroeste. ${ }^{13}$ Com a integração dessas regiões ao restante do estado pelas ferrovias, as terras novas e mais produtivas

\footnotetext{
12 São Paulo, Estatística Agrícola.

${ }^{13}$ Brasil, Recenseamento 1920, v. III, 2a parte.
} 
tornaram-se atrativas para os cafeicultores, como pode ser visto pelo aumento do número de propriedades nessas regiões. ${ }^{14}$

Onde o café não predominava, o cultivo de alimentos era mais expressivo, como era o caso da Baixa Sorocabana que possuía $87 \%$ da área cultivada produzindo arroz, milho e feijão, da Sorocaba, com 78\%, e da Noroeste, $56 \%$ com os mesmos produtos. Em 1920, o cultivo de alimentos dominou mais da metade da área cultivada do estado. A área cultivada com arroz aumentou em $365 \%$, enquanto o cultivo do milho se expandiu em $150 \%$ e o de feijão em $125 \%$. Observando os dados por regiões, nota-se que não há um padrão claro nesse aumento. A expansão da cultura de alimentos aconteceu tanto na zona cafeeira quanto nas áreas de fronteira. ${ }^{15}$

Esse breve panorama resume a expansão da agricultura paulista entre 1905 e 1920. Conforme as regiões eram atingidas pela ferrovia, novos municípios foram surgindo e novas terras se tornaram disponíveis para agricultura. O número total de propriedades rurais no estado de São Paulo cresceu, assim como a área cultivada e a produção cafeeira e de alimentos. Esse crescimento, porém, não foi uniforme, tendo ocorrido nas áreas novas do estado, enquanto nas zonas mais tradicionais houve redução do número das propriedades. A próxima seção traz uma análise detalhada das propriedades dos estrangeiros e de seu peso na agricultura paulista.

\subsection{As propriedades dos estrangeiros}

Ainda que diversos trabalhos tenham investigado a concentração fundiária, tamanho e distribuição das propriedades rurais no início do século $\mathrm{XX}$, há poucas análises sobre a presença do imigrante enquanto proprietário rural. ${ }^{16}$ Como visto nos

\footnotetext{
${ }^{14}$ Monbeig, Pioneiros, 170-1; Holloway, Imigrantes, 102-4.

${ }^{15}$ Colistete, "Regiões," 343-51.

${ }^{16}$ Sobre o desenvolvimento das propriedades rurais em São Paulo, ver: Monbeig, Pioneiros; Lucila R. Brioschi, "Fazendas de Criar," in Na Estrada do Anhangüera. Uma Visão Regional da História Paulista, ed. Carlos de A. P. Bacellar e Lucila R. Brioschi (São Paulo: Humanitas, 1999), 56-89; Milliet, "Roteiros". Sobre a ocupação da terra e formação das propriedades rurais na região Noroeste, ver Nilson Ghirardello, À beira da linha: formações urbanas da Noroeste Paulista (São Paulo: Editora UNESP, 2001); para a região cafeeira, em especial a Mogiana, ver: Frederick V. Gifun, "Ribeirão Preto, 18801914: The Rise of a Coffee County, or the Transition to Coffee in São Paulo as Seen Through the Development of Its Leading Producer" (Ph.D. diss., University of Florida, 1972); Renato Marcondes, "O Café em Ribeirão Preto (1890-1940)," História Econômica \& História de Empresas 10, n. 1 (2007); Pedro Geraldo Tosi, Rogério Naques Faleiros e Rodrigo da Silva Teodoro, "Fragmentos de um modelo: pequenas lavouras de café e acumulação de capitais. Franca/São Paulo 1890-1914," História 24, n. 2 (2005); Renato P. Colistete e Maria Lucia Lamounier, "Land Inequality in a Coffee Economy: São Paulo During the Early Twentieth Century," Department of Economics, FEA-USP Working Paper n. 2014-1 (2014).
} 
capítulos anteriores, o anseio de se tornarem proprietários de terras foi um dos principais motores da imigração dos europeus para São Paulo. ${ }^{17}$ No entanto, as políticas implementadas pelo governo refletiram os interesses da elite cafeicultora, para quem os imigrantes deveriam vir comprometidos com o trabalho nas fazendas e não para se tornarem proprietários quando de sua chegada. As políticas visando o acesso à terra pelos imigrantes, como a fundação de núcleos coloniais no estado, ficaram em segundo plano e pareciam ter mais caráter de propaganda. $\mathrm{O}$ que se observa pelas estatísticas oficiais, no entanto, é um cenário bem diferente dos anseios iniciais dos cafeicultores. Vinte anos após o começo da grande onda de imigração para o estado de São Paulo, a Estatística Agrícola de 1905 mostrou que os estrangeiros de fato se tornaram proprietários rurais, possuindo 8.560 estabelecimentos rurais no estado, correspondendo a $15 \%$ do total. Se considerarmos apenas o Oeste paulista - composto pelas regiões Central, Mogiana, Paulista, Araraquarense, Alta Sorocaba e Noroeste - os imigrantes eram quase $40 \%$ dos proprietários rurais.

Ainda que não traga dados individuais dos produtores rurais, o panorama apresentado pelo Censo de 1920 permite verificar o crescimento da participação dos estrangeiros como proprietários de terra no estado de São Paulo. Quinze anos após o primeiro levantamento completo da agricultura paulista, os dados mostravam um claro aumento dos imigrantes como proprietários de terras, conforme já observado pela literatura. ${ }^{18}$ Nesta seção, detalha-se a distribuição das propriedade dos estrangeiros em São Paulo. Será apresentado um retrato de onde se localizavam essas propriedades, o seu tamanho e seu peso na agricultura paulista.

\subsubsection{Localização}

As propriedades rurais dos estrangeiros em 1905 concentravam-se principalmente na região cafeeira do estado. A região Araraquarense abrigava $20 \%$ desses estabelecimentos, seguida pela Paulista com 18\%, Central (17,3\%), Mogiana (14\%) e Alta Sorocabana (10\%). O Vale do Paraíba, apesar de decadente em 1905, possuía 8,5\% das propriedades rurais pertencentes aos nascidos fora do Brasil. Nas demais regiões quase não se registraram terras de estrangeiros. A Tabela 3.4 traz a

\footnotetext{
${ }^{17}$ Holloway, Imigrantes, 212-3; Dean, “A Pequena Propriedade," 487; Petrone, "Imigração," 128; Klein, "European".

${ }^{18}$ Holloway, Imigrantes, cap. 6; Camargo, Crescimento, 234.
} 
localização das propriedades por nacionalidade nas regiões do estado de São Paulo em 1905.

Os italianos, nacionalidade mais numerosa no estado de São Paulo entre 1886 e 1920, predominavam entre os estrangeiros que adquiriram terras no território paulista, possuindo $62 \%$ dos estabelecimentos pertencentes a estrangeiros em 1905. Suas propriedades estavam localizadas principalmente na Araraquarense, onde havia 22,4\% de todos os estabelecimentos rurais dos italianos, Central (19,3\%) e Mogiana (15,8\%). Os portugueses vinham em seguida, possuindo 19,3\% das propriedades de estrangeiros no estado, concentradas na Paulista (22\%), Vale do Paraíba (15\%) e Mogiana (14,2\%). A região da Paulista foi pioneira, logo em meados do século XIX, no uso de mão de obra imigrante portuguesa e alemã nas fazendas, e ainda era, em 1905, onde essas duas nacionalidades principalmente se concentravam. ${ }^{19}$

Tabela 3.4 - Nacionalidades dos proprietários rurais nas regiões do estado de São Paulo, 1905, absoluto e em porcentagem

\begin{tabular}{ccccccc}
\hline & Brasileiros & Italianos & Espanhóis & Portugueses & Alemães & Austríacos \\
\hline Capital & $1.952(4,0)$ & $287(5,4)$ & $18(3,8)$ & $182(11,0)$ & $64(9,3)$ & $1(0,9)$ \\
Vale do Paraíba e & $13.526(27,8)$ & $320(6,0)$ & $89(18,8)$ & $249(15,1)$ & $19(2,8)$ & $2(1,8)$ \\
Litoral Norte & & & & & & \\
Sorocaba & $2.440(5,0)$ & $62(1,2)$ & $8(1,7)$ & $25(1,5)$ & $23(3,3)$ & $2(1,8)$ \\
Central & $6.195(12,7)$ & $1.021(19,3)$ & $92(19,5)$ & $140(8,5)$ & $125(18,2)$ & $16(14,0)$ \\
Mogiana & $6.886(14,2)$ & $835(15,8)$ & $16(3,4)$ & $234(14,2)$ & $65(9,4)$ & $33(28,9)$ \\
Paulista & $3.019(6,2)$ & $822(15,5)$ & $70(14,8)$ & $362(22,0)$ & $254(36,9)$ & $11(9,6)$ \\
Araraquarense & $3.937(8,1)$ & $1.188(22,4)$ & $101(21,4)$ & $229(13,9)$ & $80(11,6)$ & $16(14,0)$ \\
Noroeste & $273(0,6)$ & $35(0,7)$ & $8(1,7)$ & $17(1,0)$ & $6(0,9)$ & $0(0,0)$ \\
Alta Sorocabana & $4.152(8,5)$ & $629(11,9)$ & $58(12,3)$ & $160(9,7)$ & $36(5,2)$ & $8(7,0)$ \\
Baixa Sorocabana & $4.052(8,3)$ & $29(0,5)$ & $0(0,0)$ & $6(0,4)$ & $3(0,4)$ & $2(1,8)$ \\
Santos e Litoral Sul & $2.219(4,6)$ & $69(1,3)$ & $13(2,7)$ & $45(2,7)$ & $13(1,9)$ & $23(20,2)$ \\
\hline Total Geral & $48.651(100,0)$ & $5.297(100)$ & $473(100)$ & $1.649(100)$ & $688(100)$ & $114(100)$ \\
\hline
\end{tabular}

Fonte: São Paulo, Estatística Agrícola, 1905.

Nota: Considerando os 171 municípios do estado.

Pela Tabela 3.4 acima observa-se que 36,9\% das propriedades rurais de alemães baseavam-se na Paulista. As terras dos alemães também estavam localizadas na Central $(18,2 \%)$ e na Araraquarense $(11,6 \%)$. Os espanhóis, grupo de imigração mais tardia em

\footnotetext{
${ }^{19}$ Holloway, Imigrantes, 224-6; Dean, Rio Claro, 179-82.
} 
São Paulo, adquiriram terras principalmente na Araraquarense $(21,4 \%)$, na Central $(19,5 \%)$ e na Paulista $(14,8 \%) .{ }^{20}$ Para os espanhóis, comprar terras na principal região cafeeira do estado em 1905, a Mogiana, não parece ter sido uma realidade. Apenas 3,4\% das propriedades desses imigrantes estavam nessa última região.

Observando na Tabela 3.5 o percentual de propriedades de estrangeiros em relação ao total de propriedades de cada região, vê-se a Paulista e a Araraquarense como as zonas com maior presença de estrangeiros entre os proprietários rurais com, respectivamente, $33,8 \%$ e $29,6 \% .{ }^{21}$ Observa-se também que a Noroeste, apesar de ainda ser constituída apenas pelo município de Bauru, tinha 19,9\% de suas propriedades rurais em mãos de estrangeiros. Na Alta Sorocabana essa figura era de 17,9\%.

Tabela 3.5 - Propriedades rurais por nacionalidade em cada região do estado de São Paulo, 1905, em porcentagem

\begin{tabular}{cccccccc}
\hline & Estrangeiros & Italianos & Espanhói & Portugueses & Alemãe & Austríaco & \multirow{2}{*}{ Outros } \\
& & & $\mathrm{s}$ & & $\mathrm{s}$ & $\mathrm{s}$ & \\
\hline Capital & 22,7 & 11,4 & 0,7 & 7,2 & 2,5 & 0,0 & 0,8 \\
Vale do Paraíba e & 5,1 & 2,2 & 0,6 & 1,7 & 0,1 & 0,0 & 0,3 \\
Litoral Norte & & & & & & & \\
Sorocaba & 5,1 & 2,4 & 0,3 & 1,0 & 0,9 & 0,1 & 0,4 \\
Central & 19,3 & 13,3 & 1,2 & 1,8 & 1,6 & 0,2 & 1,2 \\
Mogiana & 14,8 & 10,3 & 0,2 & 2,9 & 0,8 & 0,4 & 0,2 \\
Paulista & 33,8 & 18,0 & 1,5 & 7,9 & 5,6 & 0,2 & 0,5 \\
Araraquarense & 29,6 & 21,2 & 1,8 & 4,1 & 1,4 & 0,3 & 0,8 \\
Noroeste & 19,9 & 10,3 & 2,3 & 5,0 & 1,8 & 0,0 & 0,6 \\
Alta Sorocabana & 17,9 & 12,4 & 1,1 & 3,2 & 0,7 & 0,2 & 0,3 \\
Baixa Sorocabana & 1,1 & 0,7 & 0,0 & 0,1 & 0,1 & 0,0 & 0,1 \\
Santos e Litoral Sul & 9,1 & 2,8 & 0,5 & 1,8 & 0,5 & 0,9 & 2,5 \\
\hline Total Geral & 15,0 & 9,3 & 0,8 & 2,9 & 1,2 & 0,2 & 0,6 \\
\hline
\end{tabular}

Fonte: São Paulo, Estatística Agrícola, 1905.

Ainda pela Tabela 3.5, nota-se que um percentualmente relativamente menor $(14,8 \%)$ das propriedades rurais da região da Mogiana pertenciam a nascidos fora do país. De fato, era de se esperar que os imigrantes não tivessem tantas oportunidades de tornarem-se proprietários em meio à principal zona produtora de café do estado, com os melhores solos e os preços mais altos da terra. A participação dos estrangeiros entre os

\footnotetext{
${ }^{20}$ Sobre a imigração tardia dos espanhóis para São Paulo, Souza Martins, "A imigração".

${ }^{21}$ A participação crescente de imigrantes no quadro de proprietários rurais dessas duas regiões ao longo do tempo foi observada anteriormente por José Francisco de Camargo. Camargo, Crescimento, 241-5.
} 
proprietários das regiões do litoral e da antiga zona cafeeira era ínfima. Apenas 1,1\% das propriedades na Baixa Sorocabana, 5\% no Vale do Paraíba e na Sorocaba e 9,1\% na região de Santos pertenciam a estrangeiros.

Uma representação espacial oferece um quadro mais preciso da localização dessas propriedades no estado. Na Figura 3.1 são apresentadas as propriedades dos estrangeiros em 1905 no estado de São Paulo, em termos relativos ao total de propriedades rurais. Já a Figura 3.2 apresenta a dispersão das propriedades rurais dos estrangeiros pelo estado em 1920.

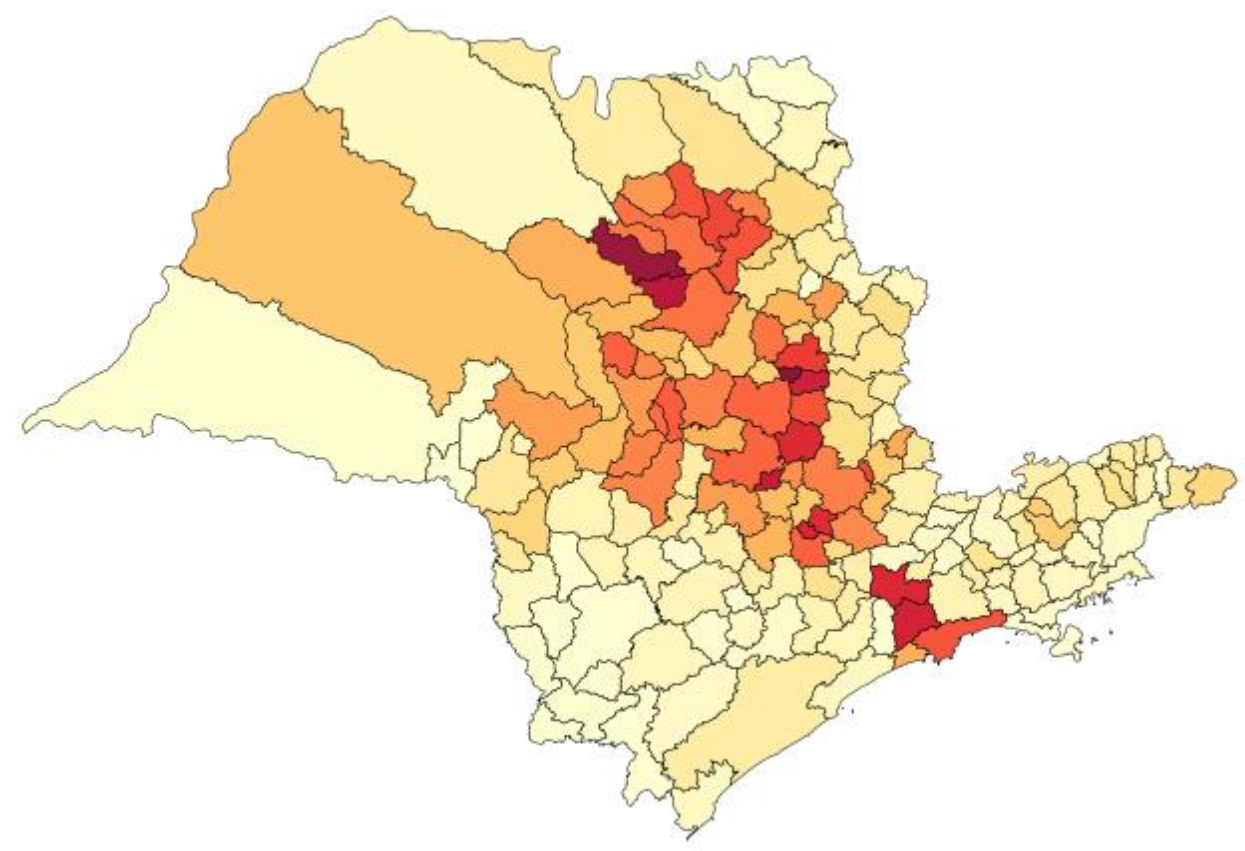

Figura 3.1 - Propriedades rurais de estrangeiros em São Paulo 1905, em termos relativos

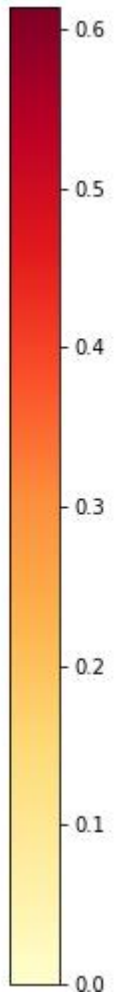
Fonte: São Paulo, Estatística Agrícola de 1905. 


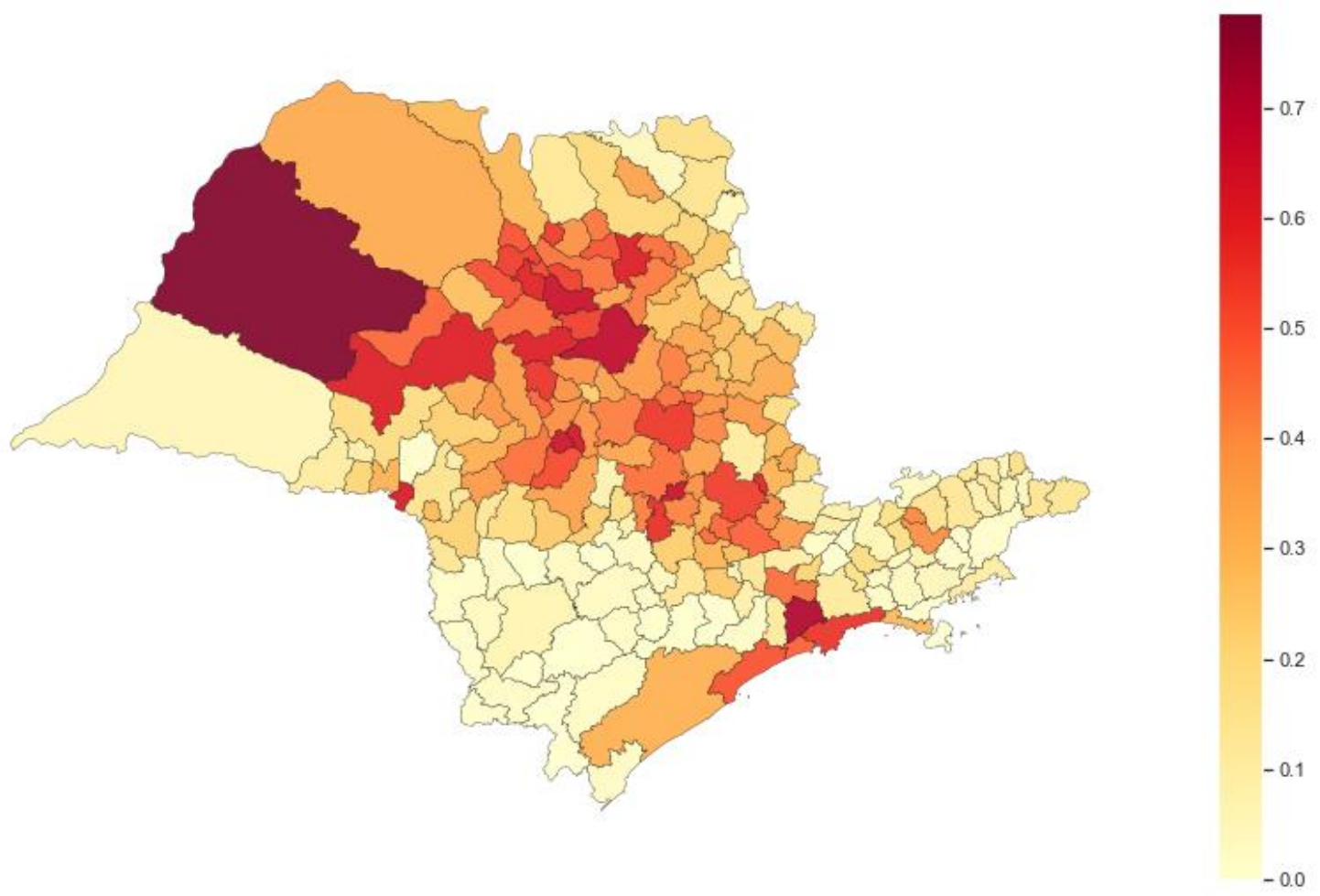

Figura 3.2 - Propriedades rurais de estrangeiros em São Paulo, 1920, em termos relativos Fonte: Brasil, Recenseamento 1920.

É possível notar a concentração das propriedades de estrangeiros nos municípios das regiões Central, Paulista e Araraquarense, bem próximas à Mogiana, o principal centro produtor cafeeiro do estado em 1905. A política defendida pelos governantes paulistas, vista anteriormente, de assentar os imigrantes próximos às fazendas cafeeiras, parece se confirmar pela Figura 3.1. Também se observa, principalmente na Figura 3.2, o crescimento da participação das propriedades de estrangeiros no total de propriedades rurais na fronteira agrícola do estado daquele momento, para municípios da Araraquarense e Alta Sorocabana.

Por outro lado, a expansão da fronteira agrícola e a integração do restante do estado de São Paulo por meio de ferrovias, durante os quinze anos que separaram a Estatística Agrícola de 1905 e o Censo de 1920, mudaram o perfil de localização das propriedades dos estrangeiros. ${ }^{22}$ Em 1905, os estrangeiros eram donos de $15 \%$ dos estabelecimentos rurais e controlavam $9 \%$ da área agrícola do estado.

\footnotetext{
${ }^{22}$ José Francisco de Camargo, em seu estudo clássico sobre o crescimento da população de São Paulo, também mostra a distribuição das propriedades dos imigrantes no estado de São Paulo em 1905 e 1920, ainda que utilizando-se de uma divisão do estado um pouco diferente da empregada aqui e realizando a análise por blocos de municípios dentro de cada região. Diferentemente do que é feito no presente trabalho, Camargo não explora a fundo a composição dessas propriedades em termos de tamanho e produção agrícola e seu peso na agricultura paulista. Camargo, Crescimento, 234-57.
} 
Conforme pode ser visto na Tabela 3.6 abaixo, em 1920 os estrangeiros aumentaram sua participação entre os proprietários do estado, possuindo então $27,3 \%$ das propriedades rurais e $13,8 \%$ da área total. Esse aumento foi observado em quase todas as regiões. Em 1920, os estrangeiros proprietários ainda estavam concentrados nas zonas cafeeiras da Mogiana, Paulista e Araraquarense. No entanto, em comparação com 1905 houve diminuição da participação dos estrangeiros na Mogiana e na Paulista e aumento para as regiões mais novas da Alta Sorocabana e Noroeste. Enquanto 17,3\% das propriedades de estrangeiros estavam na Central em 1905, em 1920 a região abrigava apenas 10,9\%. A Mogiana e a Paulista também viram a participação dos estrangeiros como donos de terra diminuir, respectivamente, de $14,1 \%$ para $12,9 \%$ e de $18,1 \%$ para $15,6 \%$ do total de propriedades de estrangeiros do estado. Apesar dessa diminuição, na Mogiana e na Paulista o número absoluto de estrangeiros proprietários dobrou no período e, se em 1905, respectivamente, $14,8 \%$ e 33,8\% dos proprietários das regiões eram estrangeiros, em 1920 essas cifras passaram a 26,0\% e 41,6\%.

Tabela 3.6 - Proprietários rurais no estado de São Paulo de acordo com a nacionalidade, por

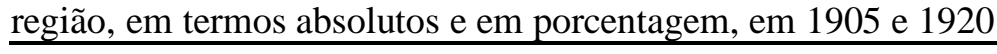

\begin{tabular}{ccccccc}
\hline \multirow{2}{*}{ Região } & \multicolumn{2}{c}{$\begin{array}{c}\text { Propriedades de } \\
\text { estrangeiros }\end{array}$} & $\begin{array}{c}\% \text { de proprietários } \\
\text { estrangeiros na região }\end{array}$ & $\begin{array}{c}\text { \% de proprietários } \\
\text { estrangeiros na região em } \\
\text { relação ao total }\end{array}$ \\
\cline { 2 - 7 } & 1905 & 1920 & 1905 & 1920 & 1905 & 1920 \\
\hline Capital & 572 & 311 & $22,7 \%$ & $13,7 \%$ & $6,7 \%$ & $1,4 \%$ \\
Vale do Paraíba e Litoral & 726 & 940 & $5,1 \%$ & $8,3 \%$ & $8,5 \%$ & $4,3 \%$ \\
Norte & 130 & 322 & $5,1 \%$ & $4,7 \%$ & $1,5 \%$ & $1,5 \%$ \\
Sorocaba & 1.485 & 2.446 & $19,3 \%$ & $33,2 \%$ & $17,3 \%$ & $10,9 \%$ \\
Central & 1.200 & 2.848 & $14,8 \%$ & $26,0 \%$ & $14,1 \%$ & $12,9 \%$ \\
Mogiana & 1.544 & 3.445 & $33,8 \%$ & $41,6 \%$ & $18,1 \%$ & $15,6 \%$ \\
Paulista & 1.659 & 6.232 & $29,6 \%$ & $43,4 \%$ & $20,0 \%$ & $28,3 \%$ \\
Araraquarense & 68 & 2.141 & $19,9 \%$ & $63,9 \%$ & $0,8 \%$ & $9,7 \%$ \\
Noroeste & 908 & 2.439 & $17,9 \%$ & $24,8 \%$ & $10,6 \%$ & $11,0 \%$ \\
Alta Sorocabana & 45 & 66 & $1,1 \%$ & $1,9 \%$ & $0,5 \%$ & $0,3 \%$ \\
Baixa Sorocabana & 223 & 875 & $9,1 \%$ & $33,5 \%$ & $2,6 \%$ & $3,9 \%$ \\
Santos e Litoral Sul & 8.560 & 22.065 & $15,0 \%$ & $27,3 \%$ & $100,0 \%$ & $100,0 \%$ \\
\hline Total & & & & & & \\
\hline
\end{tabular}

Fonte: São Paulo, Estatística Agrícola, 1905; Brasil, Recenseamento 1920.

A região da Capital, por sua vez, apresentou queda no número absoluto de propriedades de estrangeiros apenas no município de São Paulo, diminuindo de $572 \mathrm{em}$ 1905 para 311 em 1920. As regiões de ocupação mais antiga tiveram aumento do 
número de propriedades de estrangeiros. No Vale do Paraíba, 5,1\% das propriedades pertenciam a imigrantes em 1905, passando para 8,3\% em 1920. Na Baixa Sorocabana, 1,1\% das propriedades em 1905 estavam em mãos de estrangeiros, crescendo para 1,9\% em 1920.

A Araraquarense, que em 1905 já liderava com 20\% do total de estrangeiros proprietários, em 1920 consolidou sua posição com 28\% dos estabelecimentos rurais dos imigrantes, tendo um aumento de quatro vezes no número absoluto de propriedades em comparação com 1905. A Alta Sorocabana quase triplicou o número de estrangeiros proprietários em suas terras, mas, no cômputo geral, praticamente não houve diferença em relação a 1905, quando concentrava 10,6\% das propriedades. Em 1920 essa última região passou a concentrar $11,1 \%$ das propriedades de imigrantes.

A região Noroeste merece destaque. Como observado na Tabela 3.6, apesar de concentrar apenas 9,7\% do total das propriedades dos estrangeiros do estado de São Paulo, de todas as propriedades registradas na região pelo censo de 1920, 63,9\% pertenciam a estrangeiros, um salto de mais de 30 vezes em comparação com 1905, fazendo dela a única região do estado onde os imigrantes superavam os nacionais na propriedade da terra. Em alguns municípios, como em Penápolis, os estrangeiros chegaram a possuir mais de $78 \%$ das propriedades rurais em 1920. A região foi a que apresentou maior aumento relativo no número de propriedades de estrangeiros. Entre 1905 e 1920 a produção cafeeira em Bauru explodiu. Sendo o único município da região Noroeste em 1905, em Bauru havia nesse ano 2.552.000 pés de café - menos de 0,4\% do total do estado, produzindo 104.000 arrobas (menos de $0,01 \%$ do total), com uma produção média de 41 arrobas por 1.000 pés. Em 1920, em uma área bem mais reduzida após seu desmembramento em outros 5 municípios, Bauru possuía 6.485 .000 cafeeiros, produzindo 406.000 arrobas de café com uma produção média de 62,6 arrobas por 1.000 pés. Na região Noroeste como um todo, havia em 19201.806 propriedades em 14 mil alqueires, 3,3\% do total do estado, com 28 milhões de pés de café em produção, 3,4\% dos cafeeiros do estado.

Diversos fatores combinados ditaram a dispersão das propriedades de estrangeiros no interior do estado, como preço da terra, produção de café e alimentos e o traçado das linhas férreas conectando com outras zonas produtoras. ${ }^{23}$ As áreas cultivadas nas propriedades rurais em São Paulo com café e com as três principais

\footnotetext{
${ }^{23}$ Camargo, Crescimento, 235-9.
} 
culturas alimentares - milho, feijão e arroz - em 1905 mostram uma relação com a localização das propriedades pertencentes aos estrangeiros. Essa correlação pode ser medida por um coeficiente de correlação (Spearman), que mede o grau de associação entre variáveis.

A Tabela 3.7 apresenta os resultados das correlações entre a quantidade de propriedades de imigrantes em relação ao total de propriedades rurais em cada município paulista em 1905 e as áreas cultivadas com café, milho, feijão e arroz em relação à área cultivada total em cada município. Os coeficientes de correlação da Tabela 3.7 revelam que uma maior presença de propriedades de imigrantes era associada com uma maior participação da área cultivada com café e menor participação da área cultivada com gêneros do mercado interno. $\mathrm{O}$ coeficiente relacionando propriedades de imigrantes e café é positivo e significante estaticamente. Ou seja, é provável que exista uma relação entre o cultivo do café e a escolha do local onde os imigrantes buscaram adquirir propriedades. ${ }^{24}$ Os dados confirmam o que era relatado pelos viajantes no início do século $\mathrm{XX}$, isto é a tendência dos estrangeiros em acompanhar a expansão da fronteira do café no estado de São Paulo ao adquirir propriedades rurais. ${ }^{25} \mathrm{O}$ coeficiente de correlação também indica que havia uma relação negativa, ainda que não tão grande, entre a cultura de feijão e arroz, e o cultivo do café.

Tabela 3.7 - Análise de correlação entre produção agrícola e as propriedades de imigrantes para 1905

\begin{tabular}{lccccc}
\hline & $\begin{array}{c}\text { Propriedades de } \\
\text { imigrantes em } \\
\text { relação ao total }\end{array}$ & $\begin{array}{c}\text { Produção } \\
\text { relativa de } \\
\text { café }\end{array}$ & $\begin{array}{c}\text { Produção } \\
\text { relativa de } \\
\text { milho }\end{array}$ & $\begin{array}{c}\text { Produção } \\
\text { relativa de } \\
\text { feijão }\end{array}$ & $\begin{array}{c}\text { Produção } \\
\text { relativa de } \\
\text { arroz }\end{array}$ \\
\hline Propriedades de imigrantes & 1.000 & & & & \\
em relação ao total & $\mathbf{0 . 5 8 9}$ & 1.000 & & & \\
Produção relativa de café & -0.059 & -0.102 & 1.000 & & \\
Produção relativa de milho & $\mathbf{- 0 . 3 0 3}$ & $\mathbf{- 0 . 2 9 7}$ & 0.043 & 1.000 & \\
Produção relativa de feijão & -0.111 & $\mathbf{- 0 . 3 2 9}$ & -0.042 & $\mathbf{0 . 5 5 0}$ & 1.000 \\
Produção relativa de arroz & & & & &
\end{tabular}

Fonte: São Paulo, Estatística Agrícola, 1905.

Nota: Em negrito, estatisticamente significante a 5\%; Propriedades de imigrantes em relação ao total: propriedades de imigrantes em relação ao total de propriedades em 1905; Produção relativa de café: área cultivada com café em relação ao total da área cultivada em 1905; Produção relativa de milho: área cultivada com milho em relação ao total da área cultivada em 1905; Produção relativa de feijão: área cultivada com feijão em relação ao total da área cultivada em 1905; Produção relativa de arroz: área cultivada com arroz em relação ao total da área cultivada em 1905.

\footnotetext{
${ }^{24}$ Mapas com as áreas cultivadas relativas de cada gênero e sua comparação com as propriedades dos estrangeiros são apresentados no Anexo A3.3.

${ }^{25}$ Denis, Brazil. Ver, também: Monbeig, Pioneiros, 167-201; Milliet, "Roteiros," 35-70.
} 
Os coeficientes associando propriedades de imigrantes e gêneros alimentares são todos negativos, embora apenas o feijão apresentou uma correlação significativa estatisticamente. Essa correlação negativa sinaliza que os municípios onde havia mais proprietários imigrantes entre o total de proprietários rurais não estava relacionado com um cultivo maior de alimentos. A Estatística Agrícola de 1905 mostra que os municípios cujas áreas estavam mais ocupadas com cultura alimentar estavam localizados nas regiões de fronteira agrícola naquele momento - como nos municípios da Alta Sorocabana e Noroeste - ou onde o café não predominava, como era o caso dos municípios da Sorocaba e de Santos e Litoral Sul.

Em 1920 os dados refletem quase o mesmo observado para 1905. O café continuou a ter uma relação positiva e significativa com a localização das propriedades dos estrangeiros, ainda que mais fraca do que a vista em 1905. Além do feijão, o cultivo do milho em 1920 passou a ter, então, uma correlação negativa e significante estatisticamente com a localização das propriedades pertencentes aos estrangeiros. Esses resultados são apresentados na Tabela 3.8 abaixo. Como foi visto na Figura 3.2, em 1920 a localização dos proprietários estrangeiros se consolidava na fronteira agrícola e nas vizinhanças do centro cafeeiro paulista. ${ }^{26}$

Tabela 3.8 - Análise de correlação de Spearman entre produção agrícola e dispersão das propriedades de imigrantes para 1920

\begin{tabular}{lccccc}
\hline & $\begin{array}{c}\text { Propriedades de } \\
\text { imigrantes em } \\
\text { relação ao total }\end{array}$ & $\begin{array}{c}\text { Produção } \\
\text { relativa } \\
\text { de café }\end{array}$ & $\begin{array}{c}\text { Produção } \\
\text { relativa } \\
\text { de milho }\end{array}$ & $\begin{array}{c}\text { Produção } \\
\text { relativa de } \\
\text { feijão }\end{array}$ & $\begin{array}{c}\text { Produção } \\
\text { relativa de } \\
\text { arroz }\end{array}$ \\
\hline Propriedades de imigrantes & 1.000 & & & & \\
em relação ao total & $\mathbf{0 . 4 5 3}$ & 1.000 & & & \\
Produção relativa de café & $\mathbf{- 0 , 4 4 2}$ & $\mathbf{- 0 . 7 3 0}$ & 1.000 & & \\
Produção relativa de milho & $\mathbf{- 0 , 2 3 6}$ & $\mathbf{- 0 , 4 6 1}$ & $\mathbf{0 , 4 9 7}$ & 1.000 & \\
Produção relativa de feijão & 0,188 & 0,037 & $\mathbf{- 0 , 1 6 5}$ & 0,154 & 1.000 \\
Produção relativa de arroz & & & & & \\
\hline
\end{tabular}

Fonte: São Paulo, Estatística Agrícola.

Nota: Em negrito, estatisticamente significante a 5\%; Propriedades de imigrantes em relação ao total: propriedades de imigrantes em relação ao total de propriedades em 1920; Produção relativa de café: área cultivada com café em relação ao total da área cultivada em 1920; Produção relativa de milho: área cultivada com milho em relação ao total da área cultivada em 1920; Produção relativa de feijão: área cultivada com feijão em relação ao total da área cultivada em 1920; Produção relativa de arroz: área cultivada com arroz em relação ao total da área cultivada em 1920.

\footnotetext{
${ }^{26}$ Ver Anexo A3.4.
} 
O que se pode interpretar dos coeficientes apresentados nas Tabelas 3.7 e 3.8 é que o café ditava os caminhos da localização das propriedades dos estrangeiros. ${ }^{27}$ Onde o café não predominava - como no Vale do Paraíba e Litoral Norte, na Baixa Sorocabana e em Sorocaba, - a participação relativa da área cultivada com o milho e com feijão em relação à área total cultivada era maior, fato mostrado também por Renato Colistete ao analisar a agricultura paulista em $1905 .{ }^{28}$ Nessas regiões, a porcentagem de propriedades de imigrantes em relação ao total de propriedades era menor. Já onde o café dominava a área cultivada, as outras culturas não deixaram de existir, mas não predominavam. ${ }^{29}$

\subsubsection{Participação relativa das propriedades de imigrantes no estado}

Outra maneira de se analisar a localização das propriedades de imigrantes no estado de São Paulo é calculando um índice que relaciona o número de propriedades de uma nacionalidade específica em uma região e o total de propriedades daquela nacionalidade no estado como um todo. Um índice maior que 1 significa que a região possui maior participação relativa de propriedades de uma determinada nacionalidade do que a participação média dessa nacionalidade no estado. ${ }^{30}$ Esse índice pode ser definido como:

$$
\text { Participação } \begin{aligned}
& \text { região } i \\
& \text { nacionalidade n }
\end{aligned}=\left[\begin{array}{l}
\left(\frac{p_{n}}{p}\right) /\left(\frac{P_{n}}{P}\right)
\end{array}\right]
$$

Em que:

Participação $\begin{aligned} & \text { região } i \\ & \text { nacionalidade } n\end{aligned}=$ índice de participação relativa de propriedades de certa nacionalidade $\mathrm{n}$ em certa região i;

$\mathrm{p}_{\mathrm{n}}=$ proprietários da nacionalidade $\mathrm{n}$ na região $\mathrm{i}$;

$\mathrm{p}=$ total de propriedades na região $\mathrm{i}$;

$\mathrm{P}_{\mathrm{n}}=$ proprietários da nacionalidade $\mathrm{n}$ no estado de São Paulo;

$\mathrm{P}=$ total de propriedades no estado.

A Tabela 3.9 traz estimativas do índice de participação relativa das propriedades de imigrantes no estado de São Paulo em 1905. A primeira coluna apresenta a

\footnotetext{
${ }^{27}$ Ver Anexo A3.5.

${ }^{28}$ Colistete, "Regiões," 338-9.

${ }^{29}$ Colistete, "Regiões," 339.

30 O índice aqui apresentado é baseado no índice utilizado por Renato Colistete para medir a especialização produtiva na agricultura de São Paulo em 1905. Colistete, "Regiões,” 340.
} 
participação para proprietários brasileiros, enquanto as demais trazem as participações relativas de proprietários agrícolas italianos, portugueses, espanhóis, alemães e a categoria geral de "outros" estrangeiros.

Tabela 3.9 - Concentração relativa de propriedades por nacionalidade, São Paulo, 1905

\begin{tabular}{ccccccc}
\hline Região & Brasileiros & Italianos & Portugueses & Espanhóis & Alemães & Outros \\
\hline Capital & 0,94 & $\mathbf{1 , 1 1}$ & $\mathbf{2 , 0 1}$ & 0,86 & $\mathbf{1 , 8 5}$ & $\mathbf{1 , 0 5}$ \\
Vale do Paraíba e Litoral Norte & $\mathbf{1 , 1 2}$ & 0,23 & 0,63 & 0,75 & 0,12 & 0,42 \\
Sorocaba & $\mathbf{1 , 1 1}$ & 0,26 & 0,36 & 0,37 & 0,76 & 0,56 \\
Central & 0,95 & $\mathbf{1 , 4 5}$ & 0,63 & $\mathbf{1 , 4 4}$ & $\mathbf{1 , 3 4}$ & $\mathbf{1 , 7 3}$ \\
Mogiana & $\mathbf{1 , 0 0}$ & $\mathbf{1 , 1 1}$ & $\mathbf{1 , 0 3}$ & 0,24 & 0,66 & 0,92 \\
Paulista & 0,78 & $\mathbf{1 , 9 1}$ & $\mathbf{2 , 8 3}$ & $\mathbf{1 , 7 6}$ & $\mathbf{4 , 6 7}$ & $\mathbf{1 , 0 0}$ \\
Araraquarense & 0,83 & $\mathbf{2 , 3 2}$ & $\mathbf{1 , 4 3}$ & $\mathbf{2 , 1 9}$ & $\mathbf{1 , 3 6}$ & $\mathbf{1 , 1 2}$ \\
Noroeste & 0,94 & $\mathbf{1 , 1 2}$ & $\mathbf{1 , 6 6}$ & $\mathbf{2 , 8 2}$ & $\mathbf{1 , 4 9}$ & 0,71 \\
Alta Sorocabana & 0,96 & $\mathbf{1 , 3 5}$ & $\mathbf{1 , 1 1}$ & $\mathbf{1 , 5 0}$ & 0,47 & 0,81 \\
Baixa Sorocabana & $\mathbf{1 , 1 5}$ & 0,15 & 0,08 & 0,00 & 0,08 & 0,27 \\
Santos & $\mathbf{1 , 0 6}$ & 0,30 & 0,66 & 0,64 & 0,45 & $\mathbf{4 , 1 0}$ \\
\hline
\end{tabular}

Fonte: São Paulo, Estatística Agrícola, 1905.

É possível notar que as regiões fora da zona cafeeira, como o Vale do Paraíba e Litoral Norte, Sorocaba, Baixa Sorocabana e Santos e Litoral Sul diferenciavam-se pela participação relativa acima da média do estado de propriedades de brasileiros, refletindo a pouca atração que as antigas regiões cafeeiras exerciam sobre os imigrantes no começo do século XX e o baixo número de proprietários estrangeiros nessas regiões. ${ }^{31}$ Com exceção de Santos e Litoral Sul, nas outras regiões a participação de imigrantes de todas as nacionalidades no conjunto de proprietários de terra era abaixo da média do estado.

Em 1905, os estrangeiros tiveram uma participação relativa maior do que a média no estado de São Paulo nas regiões da Araraquarense, Alta Sorocabana, Noroeste, e regiões de ocupação mais antiga como a Capital, a Central e Paulista. Na Paulista, a presença de proprietários alemães era bem superior que a média do estado, o

\footnotetext{
${ }^{31}$ É válido ressaltar que muitos desses brasileiros eram descendentes de imigrantes. Em um outro estudo sobre a mobilidade socioeconômica dos primeiros trabalhadores imigrantes livres contratados do estado, mostra-se que, a partir de 13 sobrenomes germânicos listados como colonos na fazenda Ibicaba, foram localizados 66 possíveis descendentes na Estatística Agrícola de 1905. Desses, 25 possuíam sobrenome alemão, mas nacionalidade brasileira. Lanza, "E 'fizeram"'. Outros autores como Maurício Font estimam que os estrangeiros donos de terra seriam, na verdade, muito mais do que as estatísticas apresentam visto que muitos se naturalizaram ou eram descendentes diretos de imigrantes. Font, "Changing patterns".
} 
que é coerente com o fato de que nessa região ocorreram as experiências pioneiras na imigração livre de alemães e suíços. ${ }^{32}$

A Araraquarense e a Paulista são as únicas regiões a terem a participação relativa de imigrantes proprietários maior do que a média do estado para todas as nacionalidades estrangeiras. A Araraquarense possuía o maior número absoluto de propriedades pertencentes a estrangeiros, e, como indica a Tabela 3.9, apresentava a maior participação relativa de italianos donos de terra no estado. $\mathrm{Na}$ Paulista estavam em maior presença relativa os alemães. A Noroeste e a Alta Sorocabana, ainda em fase inicial de integração com o restante do estado em 1905, talvez tivessem terras a preços mais baixos que serviram de chamariz para os estrangeiros que desejavam adquirir propriedades fora da zona cafeeira. ${ }^{33}$ Os proprietários espanhóis tinham a maior participação relativa na Noroeste, enquanto na Alta Sorocabana portugueses, italianos e espanhóis proprietários estavam presentes mais do que a média do estado. A Mogiana, maior centro produtor cafeeiro do estado à época, era a única região no Oeste paulista a apresentar concentração de propriedades de nacionais e presença um pouco superior à média do estado de proprietários italianos e portugueses.

Como já observado, o Censo de 1920 não traz a nacionalidade europeia dos proprietários por municípios, apenas separando os proprietários em nacionais e estrangeiros. Ainda assim, o mesmo cálculo proposto acima pode ser aplicado nesse caso. De acordo com a Tabela 3.10 abaixo, os nacionais continuavam com presença maior que a média do estado nas regiões onde o café não predominava.

\footnotetext{
${ }^{32}$ Sobre a localização dos imigrantes alemães e de suas propriedades, ver Witzel de Souza, "From bonded," cap. 1 .

${ }^{33}$ Monbeig, Pioneiros, 181-95.
} 
Tabela 3.10 - Concentração relativa de propriedades por nacionalidade, São Paulo, 1920

\begin{tabular}{ccc}
\hline Região & Brasileiros & Estrangeiros \\
\hline Capital & $\mathbf{1 , 2 5 3}$ & 0,504 \\
Vale do Paraíba e Litoral Norte & $\mathbf{1 , 3 3 3}$ & 0,306 \\
Sorocaba & $\mathbf{1 , 3 9 6}$ & 0,174 \\
Central & 0,820 & $\mathbf{1 , 2 1 8}$ \\
Mogiana & 0,990 & 0,952 \\
Paulista & 0,746 & $\mathbf{1 , 5 2 6}$ \\
Araraquarense & 0,742 & $\mathbf{1 , 5 9 2}$ \\
Noroeste & 0,489 & $\mathbf{2 , 3 4 3}$ \\
Alta Sorocabana & $\mathbf{1 , 0 5 3}$ & 0,909 \\
Baixa Sorocabana & $\mathbf{1 , 4 4 1}$ & 0,071 \\
Santos e Litoral Sul & 0,893 & $\mathbf{1 , 2 2 5}$
\end{tabular}

Fonte: Brasil, Recenseamento 1920.

O deslocamento dos estrangeiros proprietários de terra em direção à região de fronteira é visível. ${ }^{34}$ Os estrangeiros donos de terras não apresentavam mais uma participação relativa maior que a média do estado na Alta Sorocabana. No entanto, tinham na Noroeste a maior participação do estado. Como visto anteriormente, a Noroeste em 1920 exibia mais de 60\% de suas propriedades sob controle de imigrantes. Ainda que acima da média do estado em 1920, menos estrangeiros proprietários estavam localizados na Araraquarense, Central e Paulista em relação à 1905. A região de Santos figura então como tendo maior participação relativa de estrangeiros proprietários que a média do estado e menor participação relativa de brasileiros.

\subsubsection{Tamanho das propriedades dos estrangeiros}

Em 1905, o tamanho médio das propriedades pertencentes a brasileiros era de 100 alqueires, superior ao das outras nacionalidades quando consideradas em conjunto. Das propriedades dos nacionais, 53\% eram menores que 25 alqueires, mas concentravam apenas 5,3\% das terras possuídas pelos nacionais. No outro extremo, os latifúndios representavam 3,5\% das propriedades dos nacionais, concentrando 46,6\% das terras possuídas pelos brasileiros no estado de São Paulo.

As propriedades dos estrangeiros eram, em média, metade do tamanho das propriedades dos brasileiros, ao redor de 53 alqueires. Os pequenos proprietários

\footnotetext{
${ }^{34}$ Monbeig, Pioneiros, 201-4.
} 
estrangeiros, com propriedades menores que 25 alqueires, representaram nada menos que $70 \%$ de todos os proprietários rurais estrangeiros do estado. A participação dos médios (22\%) e dos grandes proprietários $(6,5 \%)$ era bem inferior e apenas $1,1 \%$ das propriedades dos estrangeiros estava no grupo dos latifúndios. As disparidades de tamanhos das propriedades ocorriam também entre as nacionalidades dos proprietários. O tamanho médio das propriedades dos Italianos girava em torno de 32 alqueires. As propriedades de portugueses eram, em média, duas vezes maiores que a dos italianos. ${ }^{35}$ Os espanhóis, por sua vez, possuíam a menor média de propriedade, com tamanho em torno de 23 alqueires. ${ }^{36}$ Para não ocupar espaço, os dados de tamanho e produção das propriedades por nacionalidades são apresentados nos anexos A3.1 e A3.2.

Quando são observadas as outras nacionalidades constata-se um tamanho médio de mais de 220 alqueires, devido, principalmente, a outliers como a Companhia Agrícola Fazenda Dumont, em Ribeirão Preto, e a São Paulo Coffee, em São Simão, latifúndios de capital inglês que possuíam, respectivamente, 8.000 e 2.500 alqueires. Outro exemplo é a propriedade de um imigrante russo em Bananal com 10.000 alqueires totalmente sem cultivo.

Os dados nas diferentes regiões exibem outras características importantes. $\mathrm{Na}$ Tabela 3.11 pode-se observar que a porcentagem de pequenas propriedades pertencentes a estrangeiros variou de 38,2\% na Baixa Sorocabana a 91,9\% na Capital. O número para a Capital já era esperado, visto que a região era conhecida por suas pequenas propriedades voltadas para o abastecimento do meio urbano. Nenhum latifúndio pertencente a estrangeiro foi registrado na Capital. As zonas onde o café não havia se consolidado ou já tinha perdido relevância eram as que menos concentravam propriedades rurais de estrangeiros, como mencionado anteriormente. No entanto, mais imigrantes tornaram-se grandes proprietários e latifundiários nessas regiões do que no restante do estado. É o caso da Baixa Sorocabana (com 35,3\% das propriedades de imigrantes listadas como grandes); da Noroeste (12\% de grandes propriedades e $3 \%$ de latifúndios); e do Vale do Paraíba e Litoral Norte (11,1\% grandes e 2,6\% de latifúndios).

\footnotetext{
${ }^{35}$ A área média das propriedades dos portugueses era de 83 alqueires. No entanto, um único português, Abílio Soares, era dono da maior propriedade rural do estado de São Paulo, localizada em Santos, com mais de 36.000 alqueires. Sem ele na amostra, o tamanho médio das propriedades dos portugueses cai para 60 alqueires. Sobre os portugueses e sua integração no quadro de proprietários do estado, ver: Klein, "A integração".

${ }^{36}$ Sobre os espanhóis e suas propriedades, ver: Martins, "A imigração"; Herbert Klein, A imigração espanhola no Brasil (São Paulo: Ed. Sumaré, 1994).
} 
Tabela 3.11 - Propriedades rurais pertencentes a estrangeiros por tamanho em São Paulo, 190405, valores absolutos e em porcentagem

\begin{tabular}{ccccccccccc}
\hline \multicolumn{2}{c}{ Pequena } & \multicolumn{2}{c}{ Média } & \multicolumn{2}{c}{ Grande } & \multicolumn{2}{c}{ Latifúndio } & \multicolumn{2}{c}{ Total } \\
\hline $\begin{array}{c}\text { Capital } \\
\text { Rale do Paraíba e }\end{array}$ & 524 & $(91,9)$ & 31 & $(5,4)$ & 15 & $(2,6)$ & 0 & $(0,0)$ & 570 & $(100,0)$ \\
Litoral Norte & 377 & $(65,6)$ & 119 & $(20,7)$ & 64 & $(11,1)$ & 15 & $(2,6)$ & 575 & $(100,0)$ \\
Sorocaba & 75 & $(57,7)$ & 42 & $(32,3)$ & 11 & $(8,5)$ & 2 & $(1,5)$ & 130 & $(100,0)$ \\
Central & 1.005 & $(73,8)$ & 284 & $(20,9)$ & 65 & $(4,8)$ & 7 & $(0,5)$ & 1.361 & $(100,0)$ \\
Mogiana & 860 & $(71,9)$ & 208 & $(17,4)$ & 105 & $(8,8)$ & 23 & $(1,9)$ & 1.196 & $(100,0)$ \\
Paulista & 1.058 & $(68,8)$ & 369 & $(24,0)$ & 99 & $(6,4)$ & 12 & $(0,8)$ & 1.538 & $(100,0)$ \\
Araraquarense & 1.079 & $(65,7)$ & 460 & $(28,0)$ & 84 & $(5,1)$ & 19 & $(1,2)$ & 1.642 & $(100,0)$ \\
Noroeste & 39 & $(57,4)$ & 19 & $(27,9)$ & 8 & $(11,8)$ & 2 & $(2,9$ & 68 & $(100,0)$ \\
Alta Sorocabana & 393 & $(65,4)$ & 155 & $(25,8)$ & 46 & $(7,7)$ & 7 & $(1,2)$ & 601 & $(100,0)$ \\
Baixa Sorocabana & 13 & $(38,2)$ & 9 & $(26,5)$ & 12 & $(35,3)$ & 0 & $(0,0)$ & 34 & $(100,0)$ \\
Santos e Litoral Sul & 60 & $(76,9)$ & 17 & $(21,8)$ & 0 & $(0,0)$ & 1 & $(1,3)$ & 78 & $(100,0)$ \\
\hline Total & 5.483 & $(70,4)$ & 1.713 & $(22,0)$ & 509 & $(6,5)$ & 88 & $(1,1)$ & 7.793 & $(100,0)$ \\
\hline
\end{tabular}

Fonte: São Paulo, Estatística Agrícola de 1905. Pequenas propriedades - 0 a 25 alqueires; Médias propriedades - 25,01 a 100 alqueires; Grandes propriedades - 100,01 a 500 alqueires; Latifúndios - > 500 alqueires.

Nos grandes centros produtores de café, a maioria dos imigrantes proprietários possuía pequenas e médias propriedades. ${ }^{37}$ É o que se vê na Tabela 3.11 para a Mogiana, onde $71,9 \%$ dos imigrantes proprietários tinham propriedades menores que 25 alqueires e 17,4\% entre 25 e 100 alqueires, na Paulista $(68,8 \%$ de pequenas propriedades e $24,0 \%$ de médias propriedades) e Araraquarense $(65,7 \%$ de pequenas, e 28,0\% médias). Nota-se, ainda, que, em termos absolutos, foi nas regiões cafeeiras que se concentraram as grandes propriedades e os latifúndios de imigrantes.

Outro ponto de interesse no estudo das propriedades rurais dos estrangeiros é a área relativa controlada por cada proprietário. A Tabela 3.12 apresenta a porcentagem da área total e da área cultivada das propriedades rurais de estrangeiros em 1905 por região e por cada categoria de tamanho. Que entre os estrangeiros as pequenas propriedades tenham predominado não significou uma distribuição mais equitativa da terra total possuída.

\footnotetext{
${ }^{37}$ Renato Colistete e Maria Lúcia Lamounier observaram que nas regiões cafeeiras do nordeste do estado de São Paulo, ao analisar alguns municípios da região da Mogiana, havia um predomínio de pequenas e médias propriedades sobre as grandes propriedades. Colistete e Lamounier, "Land," 24-5.
} 
Tabela 3.12 - Áreas total e cultivada das propriedades de estrangeiros por tamanho em São Paulo, 1904-05, em porcentagem

\begin{tabular}{cccccccccc}
\hline & \multicolumn{2}{c}{ Pequena } & \multicolumn{2}{c}{ Média } & \multicolumn{2}{c}{ Grande } & \multicolumn{2}{c}{ Latifúndio } \\
& $\begin{array}{c}\text { Area } \\
\text { total }\end{array}$ & $\begin{array}{c}\text { Área } \\
\text { cultivada }\end{array}$ & $\begin{array}{c}\text { Área } \\
\text { total }\end{array}$ & $\begin{array}{c}\text { Área } \\
\text { cultivada }\end{array}$ & $\begin{array}{c}\text { Área } \\
\text { total }\end{array}$ & $\begin{array}{c}\text { Área } \\
\text { cultivada }\end{array}$ & $\begin{array}{c}\text { Área } \\
\text { total }\end{array}$ & $\begin{array}{c}\text { Área } \\
\text { cultivada }\end{array}$ \\
\hline Capital & 18,3 & 57,6 & 30,2 & 25,0 & 51,6 & 17,5 & 0,0 & 0,0 \\
Vale do Paraíba e Litoral Norte & 6,2 & 19,5 & 14,3 & 22,4 & 28,7 & 40,6 & 50,8 & 17,5 \\
Sorocaba & 8,7 & 28,5 & 23,8 & 44,1 & 26,9 & 24,7 & 40,6 & 2,7 \\
Central & 22,0 & 33,1 & 32,9 & 32,4 & 29,2 & 20,9 & 16,0 & 13,6 \\
Mogiana & 10,1 & 22,6 & 13,1 & 16,4 & 26,7 & 28,4 & 50,1 & 32,6 \\
Paulista & 17,6 & 25,7 & 29,3 & 32,0 & 35,0 & 32,1 & 18,1 & 10,2 \\
Araraquarense & 14,1 & 28,8 & 25,8 & 41,1 & 20,3 & 20,7 & 39,9 & 9,4 \\
Noroeste & 6,3 & 37,4 & 15,0 & 33,0 & 31,8 & 23,3 & 46,9 & 6,3 \\
Alta Sorocabana & 12,0 & 27,7 & 23,5 & 33,9 & 31,5 & 32,3 & 33,0 & 6,1 \\
Baixa Sorocabana & 4,3 & 12,1 & 17,3 & 22,7 & 78,4 & 65,2 & 0,0 & 0,0 \\
Santos e Litoral Sul & 1,1 & 42,0 & 2,5 & 29,4 & 0,0 & 0,0 & 96,5 & 28,6 \\
\hline Estado de São Paulo & 12,2 & 26,7 & 20,9 & 29,6 & 25,9 & 27,5 & 41,0 & 16,3 \\
\hline
\end{tabular}

Fonte: São Paulo, Estatística Agrícola de 1905.

Pode-se notar pela Tabela 3.12 que, apesar das pequenas propriedades serem $70,4 \%$ do total, estas controlavam apenas $12,2 \%$ da área total e $26,7 \%$ da área cultivada. As propriedades de tamanho médio detinham uma fatia um pouco maior das terras, com $20,9 \%$ da área total e 29,6\% da área cultivada. As grandes propriedades não distinguiam muito das médias nesse aspecto, controlando $25 \%$ da área total e 27,5\% da área cultivada. Os estrangeiros listados como proprietários de latifúndios, por sua vez, controlavam $41,0 \%$ da área total e apenas $16,3 \%$ da área cultivada pelos estrangeiros.

A distribuição da terra dos estrangeiros mostrou variações significativas entre regiões do estado de São Paulo. Nas regiões que mais receberam imigrantes, as pequenas e médias propriedades tiveram maior peso no total das propriedades rurais de estrangeiros, especialmente onde o café já estava perdendo importância, como a Central, cujas pequenas propriedades dos estrangeiros somavam $22,0 \%$ da terra e as médias $32,9 \%$, e a Paulista, com 17,6\% e 29,3\%, respectivamente. Nas outras regiões, as pequenas e médias propriedades detinham porcentagens da área total abaixo da média do estado para as duas categorias.

As grandes propriedades de estrangeiros apresentaram uma distribuição geográfica mais homogênea no estado de São Paulo. Os latifúndios prevaleceram nas regiões do Vale do Paraíba e da Mogiana, abrangendo 50,8\% e 50,1\% da área total, 
respectivamente. As localizações desses latifúndios podem estar relacionadas à facilidade do acesso à terra no Vale do Paraíba com a perda da importância da região na agricultura exportadora, o que provavelmente tornava a terra mais barata, enquanto na Mogiana o café deve ter atraído os imigrantes e companhias estrangeiras com grandes capitais. O mesmo não se observa para outras regiões, como na Central, onde os latifúndios possuíam $16 \%$ da terra, e na Paulista $(18,1 \%)$, por exemplo.

As pequenas e médias propriedades, de até 100 alqueires, representavam 92\% do total de propriedades rurais, controlavam 33\% das terras, plantavam 56\% da área cultivada total, produziam $65 \%$ do total de cereais e metade do café dos estrangeiros. Essas propriedades produziam 46,2\% de todo café, 65,7\% do milho, 67,3\% do arroz, $53,5 \%$ do feijão e $93,8 \%$ do algodão produzido pelos estrangeiros. Em comparação, os estabelecimentos rurais dos brasileiros pequenos e médios correspondiam a $82 \%$ do total, controlavam $20 \%$ das terras e quase $40 \%$ da área cultivada. As grandes propriedades e os latifúndios correspondiam a apenas $7,7 \%$ do total das propriedades de estrangeiros e concentravam $67,1 \%$ da terra. As grandes propriedades e os latifúndios de brasileiros eram $17,5 \%$ do total de propriedades em mãos dos nacionais, mas controlavam $78,5 \%$ das terras das propriedades dos nacionais.

Embora menor do que no caso dos brasileiros, a concentração em grandes propriedades e latifúndios era também muito alta entre os estrangeiros. Essas propriedades tendiam a cultivar uma área menor do que as propriedades pequenas e médias. De fato, a área cultivada relativa à área total diminuía gradualmente conforme aumentava o tamanho da propriedade, o que indica um maior aproveitamento do solo pelos pequenos proprietários. Nas grandes propriedades e nos latifúndios dos estrangeiros eram cultivados apenas $20 \%$ do café produzido pelos estrangeiros e $15 \%$ da produção de cereais. Os latifúndios dos estrangeiros apenas se destacavam na produção da cana, da qual eram responsáveis por $64 \%$ do total produzido pelos estrangeiros, concentrados nas regiões Central e Mogiana. ${ }^{38}$

Uma forma de se observar melhor a concentração de terras de estrangeiros é através do índice de Gini. O cálculo do índice de Gini oferece uma visão mais precisa das características da distribuição da terra relatadas até aqui. O índice varia de 0 a 1 , sendo que quanto mais próximo de 1 , mais desigual é a distribuição das terras. Para este

\footnotetext{
${ }^{38} \mathrm{O}$ Anexo A3.2 traz os dados de produção dos estabelecimentos dos estrangeiros por gênero, tamanho da propriedade e localização para o ano de 1905.
} 
cálculo, foram usados dados de 7.794 propriedades rurais de estrangeiros listadas na Estatística Agrícola de $1905 .{ }^{39}$ A tabela 3.13 apresenta os resultados.

Tabela 3.13 - Índice de Gini da área total para as propriedades rurais de imigrantes em São Paulo, 1905

\begin{tabular}{cc}
\hline Região & Gini \\
\hline Capital & 0,888 \\
Vale do Paraíba e Litoral Norte & 0,827 \\
Sorocaba & 0,758 \\
Central & 0,650 \\
Mogiana & 0,785 \\
Paulista & 0,692 \\
Araraquarense & 0,736 \\
Noroeste & 0,784 \\
Alta Sorocabana & 0,747 \\
Baixa Sorocabana & 0,554 \\
Santos e Litoral Sul & 0,972 \\
\hline Estado de São Paulo & 0,789
\end{tabular}

Fonte: Para o cálculo do índice de Gini, levou-se em conta a área total de 7785 propriedades pertencentes a indivíduos estrangeiros listas nas Estatística Agrícola e Zootecnicas de 1904-05.

O coeficiente de Gini da área total atingiu o valor de 0,789 para todas as propriedades de estrangeiros em São Paulo. A região de Santos era a mais desigual do estado, apresentando um índice de Gini de 0,972. Esse resultado pode ser explicado pela presença na amostra do único latifundiário estrangeiro na região, um português no município de Cananéia com uma fazenda de mais de 36.000 alqueires, como já observado. A região da Baixa Sorocabana, em contrapartida, apresentava o menor índice de desigualdade $($ Gini $=0,554)$. Onde o café já vinha perdendo espaço há algumas décadas, a desigualdade era mais baixa, a notar pelo índice da Central (Gini = 0,682) e Paulista $(0,692)$.

Surpreendentemente, o coeficiente de Gini das propriedades dos brasileiros no estado de São Paulo atingiu o valor de 0,776, menor que o encontrado para as propriedades de estrangeiros. O cálculo do índice de Gini feito por Renato Colistete e Maria Lúcia Lamounier para as propriedades rurais de 13 municípios do nordeste do estado - incluindo municípios da região da Mogiana - chegou a um índice de Gini de

${ }^{39}$ Para o cálculo do índice de Gini foram consideradas apenas as propriedades para as quais havia dados individuais da área total ocupada e que pertenciam a pessoas físicas. 
0,773, menor do que o encontrado para as propriedades de imigrantes na mesma região. ${ }^{40}$ Os cálculos realizados por Renato Marcondes para os municípios de Ribeirão Preto $(0,852)$ para $1904-5$ levando em conta a área total das propriedades é menor do que o encontrado aqui para as propriedades de imigrantes no mesmo município $(0,904)$. Em Ribeirão Preto, a Estatística Agrícola de 1905 mostra a existência de 83 propriedades pertencentes a estrangeiros. Um único estrangeiro, Francisco Schmidt, alemão, possuía 14 propriedades que juntas somavam 3.648 (75,1\%) dos 4.858 alqueires em mãos de estrangeiros, o que pode justificar esse índice de Gini tão elevado. Para Campinas, Marcondes chegou ao resultado de 0,727, muito superior ao encontrado aqui para os estrangeiros (0.592). ${ }^{41}$ Em 1905, havia 169 propriedades rurais de imigrantes no município, das quais 104 eram pequenas, 49 médias e 10 grandes. Essas grandes propriedades em Campinas agrupavam 1.600 (31,3\%) dos 5.099 alqueires de terras de estrangeiros.

Desta forma, observa-se que apesar da grande presença de pequenas e médias propriedades, a desigualdade entre os donos de terra estrangeiros foi tão ou maior que entre os brasileiros no início do século XX em São Paulo. A existência de vários pequenos e médios proprietários estrangeiros, no geral, não significou uma distribuição mais equitativa da terra entre essa classe de donos de terra.

Os estrangeiros faziam um uso mais intenso de suas terras, cultivando, em média, $18,3 \%$ da área de suas propriedades, enquanto os nacionais cultivavam $12 \%$ de suas terras, segundos os dados da Estatística Agrícola de 1905. Olhando especificamente para as regiões, as diferenças eram mais significativas. Na Mogiana, os nacionais cultivavam, em média, $16,6 \%$ da área de suas propriedades, enquanto os estrangeiros cultivavam 23\%. Na Paulista era similar, com os nacionais cultivando $15 \%$ e os estrangeiros, $26 \%$. Na Araraquarense os nacionais plantavam 12\% e os estrangeiros 19\%, e Alta Sorocabana, nacionais 9\% e estrangeiros 16\%. Na Central a parcela de área cultivada era similar. Os nacionais apenas superavam os estrangeiros na região litorânea e na região mais antiga do estado, Santos e Litoral Sul e Vale do Paraíba e Litoral Norte. A Figura 3.3 abaixo apresenta esses dados.

\footnotetext{
${ }^{40}$ Colistete e Lamounier, "Land," 17.

41 Renato Leite Marcondes, "A estrutura fundiária e cafeeira de dois municípios do oeste paulista: Campinas e Ribeirão Preto no início do século XX," Revista de História 165 (jul./dez, 2011): 416.
} 


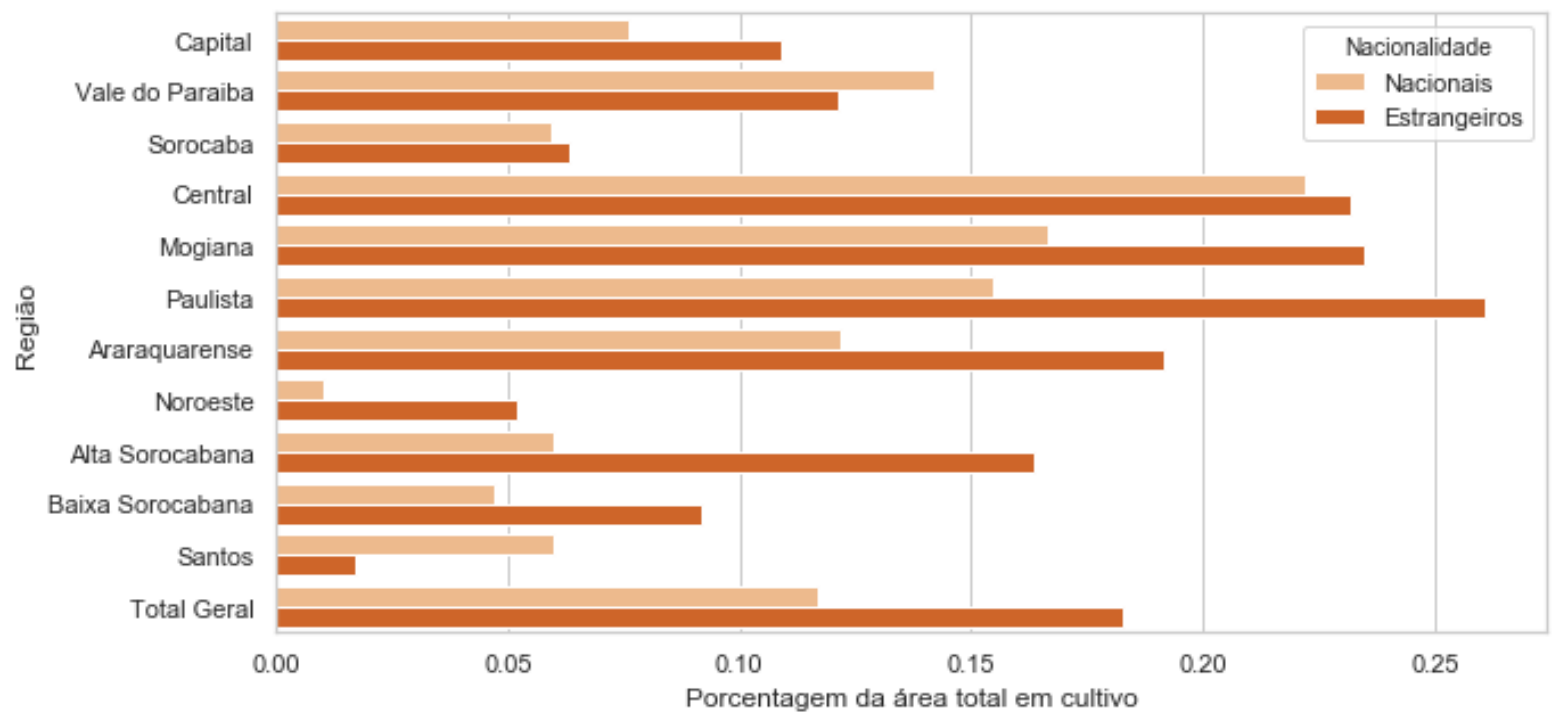

Figura 3.3 - Porcentagem da área total em cultivo por nacionais e estrangeiros, por região, 1905 Fonte: São Paulo, Estatística Agrícola.

Em 1920, a falta de dados de proprietários individuais impede uma avaliação detalhada como a feita acima para o ano de 1905. Os dados mostram que para o estado de São Paulo o tamanho médio das propriedades diminuiu no período entre os dois levantamentos, com as dos nacionais passando de 104 alqueires em 1905 para 74 alqueires em 1920 e as dos estrangeiros de 54 para 36 alqueires. O censo de 1920 lista 25 nacionalidades distintas de proprietários no estado. Italianos, Portugueses e Espanhóis continuaram liderando o número de proprietários estrangeiros, seguidos por um grupo novo, que não havia iniciado sua imigração em 1905 - os japoneses. Os portugueses continuavam com as maiores propriedades dentre essas quatro nacionalidades, com uma área média de 46 alqueires (contra 84 alqueires em 1905). Os italianos vinham em seguida, com 32 alqueires (a mesma que em 1905), diminuindo a disparidade vista entre as duas nacionalidades em 1905. As propriedades dos espanhóis também mantiveram em 1920 o tamanho médio observado em 1905, de 24,4 alqueires. Já os alemães diminuíram de 89 alqueires em 1905 para 13,6 em 1920.

A Tabela 3.14 abaixo traz informações sobre a área ocupada pelas propriedades dos estrangeiros em 1920 em São Paulo. No estado como um todo os estrangeiros possuíam $14 \%$ da terra ocupada, um pequeno aumento em relação a 1905, quando ocuparam 9\% da área rural paulista em mãos de particulares. Apesar de possuírem mais de $40 \%$ das propriedades na Araraquarense e Paulista e 64\% dos estabelecimentos rurais da Noroeste, em termos de área total os números são outros. Na Araraquarense, as propriedades dos estrangeiros se estendiam por pouco mais de $22 \%$ da área total das 
propriedades da região em 1920, frente a 15,1\% em 1905. Na Paulista, essa participação era de apenas $16,5 \%$, ainda assim maior que os $11,3 \%$ registrados em 1905 . A região com maior domínio da terra pelos estrangeiros era a Noroeste, onde passaram de 2,5\%, em 1905, para 25\% da área total das propriedades. Apesar da participação na área total não ser tão grande, chama a atenção o aumento da participação dos imigrantes na terra ocupada em todo o estado. Se levar-se em consideração que em 1920, quase 35 anos após o início da imigração em massa para São Paulo, muitos dos brasileiros listados como proprietários rurais poderiam ser imigrantes de segunda geração, a participação dos estrangeiros na ocupação da terra seria ainda maior.

Tabela 3.14 - Área ocupada das propriedades rurais no estado de São Paulo em 1920, por região e nacionalidade, em alqueires

\begin{tabular}{cccc}
\hline Região & Área total & Área Brasileiros & Área estrangeiros \\
\hline Capital & 56.273 & $46.676(82,9)$ & $4.329(7,7)$ \\
Vale do Paraíba e & 476.750 & $352.800(74)$ & $70.254(14,7)$ \\
Litoral Norte & & & \\
Sorocaba & 259.727 & $209.502(80,7)$ & $13.760(5,3)$ \\
Central & 342.151 & $193.755(56,6)$ & $73.724(21,5)$ \\
Mogiana & 939.902 & $711.580(75,7)$ & $83.761(8,9)$ \\
Paulista & 694.381 & $440.487(63,4)$ & $114.581(17,5)$ \\
Araraquarense & 937.956 & $633.591(67,7)$ & $208.261(22,2)$ \\
Noroeste & 327.938 & $196.241(59,8)$ & $83.048(25,3)$ \\
Alta Sorocabana & 1.032 .540 & $735.857(71,3)$ & $96.612(9,4)$ \\
Baixa Sorocabana & 488.119 & $457.390(93,7)$ & $14.805(3,0)$ \\
Santos e Litoral Sul & 176.656 & $81.824(46,3)$ & $27.715(15,7)$ \\
\hline Total & 5.732 .393 & $4.059 .703(70,8)$ & $790.850(13,8)$ \\
\hline
\end{tabular}

Fonte: Brasil, Recenseamento 1920.

$\mathrm{Na}$ Mogiana, como visto, o número de propriedades de estrangeiros passou de 8.086 em 1905 para 10.996 em 1920. A área ocupada por essas propriedades, no entanto, declinou de 9,8\% em 1905 para 8,9\% em 1920. Uma diminuição ainda maior foi observada em Santos, onde as propriedades de estrangeiros passaram a ocupar $15,7 \%$ da área rural da região, frente aos $44,5 \%$ registrados em $1905 .^{42}$

\footnotetext{
${ }^{42}$ Como mencionado, no município de Cananéia, região de Santos e Litoral Sul, em 1905, foi registrada a propriedade de um português, Abilio Soares, contendo 36.096 alqueires, o equivalente a $96 \%$ de toda a área em mãos de estrangeiros na região. Por isso a Estatística Agrícola de 1905 registra que 44\% da terra da região de Santos pertencia a estrangeiros.
} 
O aumento do total de propriedades de estrangeiros na Mogiana em $1920 \mathrm{em}$ comparação a 1905 e a diminuição da área ocupada por elas pode sugerir uma proliferação de pequenas e médias propriedades na região. Nas outras áreas, o crescimento no número de proprietários rurais estrangeiros acompanhado pelo aumento da participação na área total possuída não nos permite formular hipótese similar.

\subsubsection{Produção das propriedades dos imigrantes}

Os imigrantes proprietários participaram de maneira expressiva do cultivo de todos os gêneros produzidos no estado de São Paulo, desde produtos voltados para a exportação até gêneros para o mercado interno. Olhando em termos de produção por região, pela Tabela 3.15 pode-se ver que o café produzido pelos estrangeiros, apesar de concentrado na Mogiana (31,2\%) e na Paulista (22,6\%), já aparecia com relevância nas regiões de fronteira. A Araraquarense (24,7\%) possuía a segunda maior participação na área cultivada com café pelos estrangeiros e a Alta Sorocabana (7\%) a quarta. Nessas zonas também encontravam-se as maiores áreas cultivadas com gêneros alimentícios, coincidindo com o que Renato Colistete notou para a produção geral do estado de São Paulo em 1905. ${ }^{43}$

A Tabela 3.15 indica também que o cultivo dos principais gêneros alimentícios milho, arroz e feijão - nos estabelecimentos rurais dos estrangeiros se concentrava principalmente na Mogiana, onde estavam 32,2\% do arroz, 25\% do milho e $41 \%$ do feijão, apesar de, como visto, apenas $14 \%$ dos estabelecimentos rurais de estrangeiros estarem localizados nessa região. Na Araraquarense, região com $20 \%$ do total das propriedades dos estrangeiros, eram cultivados $22,7 \%$ do arroz, $17,7 \%$ do milho e $9,5 \%$ do feijão produzidos pelos imigrantes. As propriedades localizadas na zona Central destacavam-se na cultura da cana-de-açúcar e do algodão, já em substituição à produção cafeeira que vinha perdendo espaço. Na região da Capital, a única cultura de destaque era de outros gêneros alimentícios, como batatas, hortaliças e legumes, possivelmente cultivados em chácaras e sítios, além dos núcleos coloniais ainda existentes ao redor de São Paulo voltados ao abastecimento do mercado local.

\footnotetext{
${ }^{43}$ Colistete, "Regiões," 339-40.
} 
Tabela 3.15 - Área cultivada de cada produto nas propriedades de estrangeiros, por região 1904-1905 (em porcentagem)

\begin{tabular}{cccccccc}
\hline & Café & $\begin{array}{c}\text { Cana-de- } \\
\text { açúcar }\end{array}$ & Algodão & Arroz & Milho & Feijão & diversas \\
\hline Capital & 0,1 & 0,5 & 0,0 & 0,06 & 0,7 & 0,8 & 21,2 \\
Vale do Paraíba e & 5,9 & 8,3 & 0,0 & 8,4 & 6,5 & 9,4 & 18,4 \\
Litoral Norte & & & & & & & \\
Sorocaba & 0,1 & 0,8 & 25,4 & 0,5 & 1,4 & 0,9 & 3,4 \\
Central & 6,8 & 32,4 & 47,4 & 11,8 & 17,3 & 10,2 & 35,2 \\
Mogiana & 31,2 & 20,9 & 1,0 & 32,2 & 25,0 & 41,6 & 7,4 \\
Paulista & 22,6 & 19,1 & 0,3 & 18,2 & 23,6 & 23,9 & 7,9 \\
Araraquarense & 24,7 & 12,1 & 0,4 & 22,7 & 17,8 & 9,5 & 1,6 \\
Noroeste & 0,3 & 0,3 & 0,0 & 0,4 & 0,6 & 0,3 & 0,1 \\
Alta Sorocabana & 7,7 & 5,3 & 16,6 & 4,2 & 6,7 & 3,3 & 2,8 \\
Baixa Sorocabana & 0,3 & 0,05 & 8,8 & 0,4 & 0,5 & 0,2 & 0,6 \\
Santos & 0,3 & 0,2 & 0,0 & 0,9 & 0,1 & 0,1 & 1,5 \\
\hline Total Geral & 100,0 & 100,0 & 100,0 & 100,0 & 100,0 & 100,0 & 100,0 \\
\hline
\end{tabular}

Fonte: São Paulo, Estatística Agrícola.

Mesmo nas propriedades dos estrangeiros que, como visto, eram menores que a dos nacionais, o café estava presente. ${ }^{44}$ Segundo a Estatística Agrícola de 1905, no estado como um todo o café era cultivado por 22.231 propriedades, em uma área de 347.080 alqueires - 60\% da área em plantio do estado - que rendeu 36.324.161 arrobas no ano agrícola de 1904-05. Os estrangeiros foram responsáveis por 15\% dessa produção cultivada em 4.544 estabelecimentos dos seus estabelecimentos rurais, em uma área de 51.537 alqueires que correspondia a $67 \%$ da área plantada pelos estrangeiros e a $9 \%$ da área cultivada total do estado. Chama a atenção o fato dos imigrantes se dedicarem relativamente mais à produção cafeeira que os nacionais. Enquanto entre os nacionais o café era produzido em 43,0\% das propriedades, entre os estrangeiros essa proporção subia para $58,9 \% .{ }^{45}$

Apesar de se dedicarem com destaque ao cultivo do café em suas propriedades, a participação da produção dos estrangeiros nas zonas do estado era relativamente baixa, como pode-se notar na Tabela 3.16 abaixo. Nas principais zonas produtoras de café, Mogiana e Paulista, os imigrantes plantaram café em 84,3\% e 69,7\% da área cultivada de suas propriedades, respectivamente, superior à média das propriedades dos estrangeiros no estado (66,9\%), mas produziam apenas $14,6 \%$ do total de café nessas

\footnotetext{
${ }^{44}$ Renato Colistete mostra também que a produção cafeeira não era exclusividade das grandes propriedades em São Paulo. Colistete, "Regiões," 345-6.

${ }^{45}$ Ver Anexo A3.2 e A3.3.
} 
duas regiões em 1905. Os dados sobre a área cultivada das propriedades dos estrangeiros estão no anexo A3.3. A explicação para essa baixa participação na produção cafeeira total apesar de dedicarem grande parte da área cultivável de suas propriedades ao café pode residir na predominância de grandes propriedades e de latifúndios de brasileiros nessa região e na importância da região para a agroexportação, que não deixaria muito espaço para competição dos pequenos proprietários estrangeiros. Já na Araraquarense, os imigrantes dedicaram $74,4 \%$ da área cultivável de suas propriedades à cafeicultura e produziram $22,8 \%$ do café cultivado na zona no ano agrícola de 1904-05.

Tabela 3.16 - Participação da produção dos produtos cultivado nas propriedades de estrangeiros na produção total cultivada do produto, por região, 1905 (em porcentagem)

\begin{tabular}{ccccccc}
\hline Região & Café & $\begin{array}{c}\text { Cana-de- } \\
\text { açúcar }\end{array}$ & Algodão & Arroz & Milho & Feijão \\
\hline Capital & 5,7 & 0,0 & 0,0 & 17,8 & 4,2 & 2,7 \\
Vale do Paraíba e & 8,5 & 7,4 & 0,0 & 13,7 & 6,4 & 5,2 \\
Litoral Norte & & & & & & 2,7 \\
Sorocaba & 3,4 & 0,0 & 2,2 & 3,1 & 2,8 \\
Central & 6,7 & 64,8 & 10,5 & 27,1 & 11,4 & 9,7 \\
Mogiana & 14,6 & 26,0 & 22,4 & 16,4 & 13,6 & 20,8 \\
Paulista & 14,6 & 28,8 & 0,8 & 19,6 & 18,3 & 17,2 \\
Araraquarense & 22,8 & 50,0 & 3,7 & 20,2 & 22,3 & 24,2 \\
Noroeste & 6,4 & 35,2 & 0,0 & 12,6 & 10,4 & 12,0 \\
Alta Sorocabana & 12,1 & 3,1 & 10,1 & 7,4 & 8,6 & 10,3 \\
Baixa Sorocabana & 11,9 & 0,8 & 5,5 & 1,3 & 0,9 & 1,1 \\
Santos e Litoral Sul & 58,6 & 0,0 & 0,0 & 5,2 & 7,1 & 4,6 \\
\hline Média geral & 14,3 & 38,7 & 5,7 & 16,3 & 12,1 & 14,5 \\
\hline
\end{tabular}

Fonte: São Paulo, Estatística Agrícola.

A produção de alimentos era grande no estado, ocupando $42,4 \%$ da área cultivada total. Milho era produzido por quase $80 \%$ das propriedades agrícolas e era o principal produto primário destinado à alimentação. Em seguida vinham o feijão e o arroz. No entanto, a área cultivada somada desses três produtos era apenas $71,1 \%$ da área destinada ao café, mostrando que o produto voltando para o mercado externo dominava o cenário agrícola do estado em 1905. Os estrangeiros produziam 12,1\% de todo o milho, $14,5 \%$ do feijão e $16,3 \%$ do arroz do estado. Comparativamente aos nacionais, menos propriedades de imigrantes se dedicavam ao cultivo desses produtos, mas de maneira não significativa. $\mathrm{O}$ milho era produzido em $72 \%$ das propriedades dos 
estrangeiros e $75 \%$ das nacionais. O feijão, em apenas $46,8 \%$ dos estabelecimentos de estrangeiros frente a $60 \%$ dos nacionais. Somente o cultivo do arroz ocorria de forma equivalente em ambos os casos, com 33,9\% das propriedades dos nacionais e dos estrangeiros dedicadas à sua produção. Os estrangeiros tinham, contudo, uma participação relativamente alta na produção de outros produtos agrícolas, sendo responsáveis por $38,7 \%$ da cana-de-açúcar do estado. A produção da cana se concentrava principalmente na zona Central, onde o café vinha perdendo espaço em detrimento de outras culturas. Os estrangeiros foram responsáveis por $64,8 \%$ da cana plantada dessa região. O cultivo do algodão também teve importância com $5,7 \%$ do total, apesar de ser produzido em apenas $1,5 \%$ das propriedades, localizadas principalmente Mogiana, Central e Alta Sorocabana. ${ }^{46}$

Os imigrantes que passaram de colonos para proprietários parecem ter modificado a sua especialização na cultura agrícola. Se quando colonos nas fazendas cafeeiras os imigrantes dependiam em parte do cultivo de gêneros alimentícios para complementar sua renda, quando se tornaram proprietários passaram a se dedicar mais à cultura cafeeira e a de outros produtos. A Figura 3.4 abaixo indica essa característica ao mostrar que os estrangeiros proprietários dedicavam relativamente uma área cultivada maior de suas terras ao plantio cafeeiro e que, proporcionalmente, mais propriedades produziam café e menos produziam gêneros alimentícios que em relação aos nacionais. Além disso, é alta a participação dos estrangeiros no cultivo da cana e do algodão.

\footnotetext{
${ }^{46}$ Os cálculos foram feitos levando-se em conta 49.301 propriedades no total e 7.836 propriedades rurais de estrangeiros, para as quais haviam dados de produção individuais.
} 


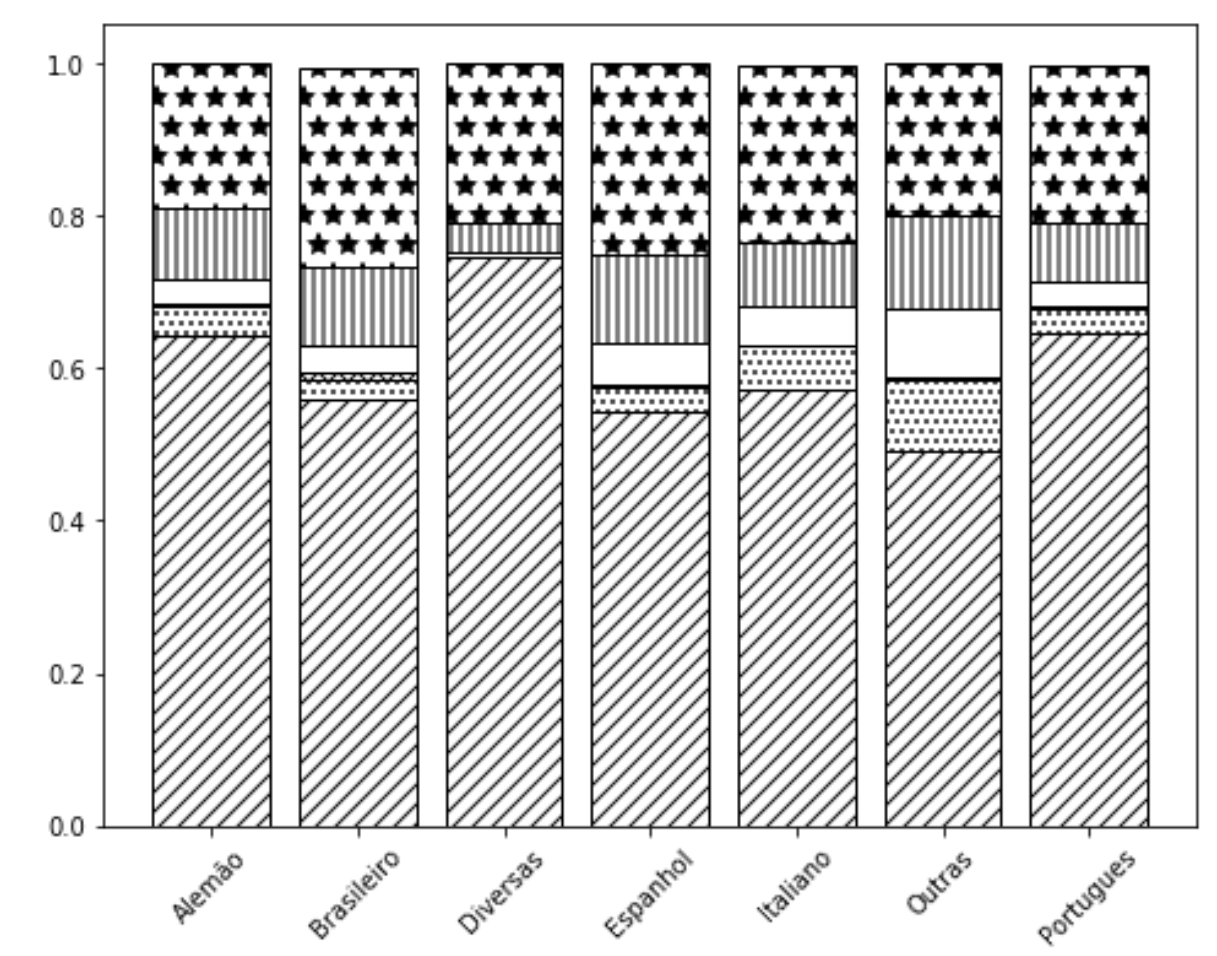

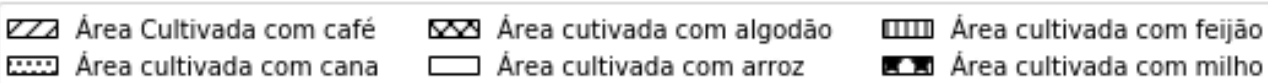

Figura 3.4 - Participação de cada gênero na área cultivada nas propriedades de estrangeiros em São Paulo, 1905

Fonte: São Paulo, Estatística Agrícola.

Verena Stolcke chama a atenção para a participação dos colonos na produção de alimentos, destacando-os como uma categoria importante no abastecimento de gêneros alimentícios no estado. ${ }^{47}$ De fato, apesar da maior participação das propriedades dos nacionais no cultivo de gêneros alimentícios, especialmente nas zonas cafeeiras, não parece ser errôneo assumir que uma parte significativa provavelmente era cultivada pelos colonos imigrantes como parte dos acordos de trabalho firmados com os cafeicultores. Foi registrada nas Estatística Agrícola de 1905 a existência de quase 429.000 trabalhadores rurais, dos quais 227.000 eram estrangeiros, distribuídos nas mais de 49.000 propriedades rurais do estado. Mais de $75 \%$ destes trabalhadores imigrantes se encontravam nas zonas Mogiana, Paulista e Araraquarense, localizados principalmente nas grandes propriedades, onde a produção de gêneros alimentícios era maior. É sabido que era comum permitir aos colonos plantarem culturas sazonais para subsistência entre os pés de café ou em áreas da fazenda menos propícias para o cultivo cafeeiro, como forma de complemento de sua renda. Como mencionado, tal prática

\footnotetext{
${ }^{47}$ Stolcke, Cafeicultura, 84 .
} 
normalmente vinha estipulada nos contratos de trabalhos firmados entre os colonos e os fazendeiros. ${ }^{48}$ Apesar de não ser possível estimar o tamanho da participação dos colonos na produção desses gêneros agrícolas dentro das fazendas cafeeiras, é possível afirmar que a participação dos estrangeiros na estrutura produtiva agrícola do estado seria ainda maior do que a registrada pelas Estatística Agrícola de 1905.

O Censo de 1920 não permite avaliar a produção das propriedades pertencentes a estrangeiros por apresentar apenas a produção total de cada gênero em cada município paulista, sem especificar nacionalidades. No entanto, um relatório apresentado pelo Secretário da Agricultura em 1923 traz informações sobre a produção cafeeira no estado e especifica a nacionalidade dos produtores e quantidade de pés de café plantados, assim como a produção naquele ano para 153 municípios cafeicultores. O levantamento indica que $40 \%$ das propriedades rurais cultivando café no estado de São Paulo pertenciam a estrangeiros, concentrando $29,7 \%$ do total de pés de café. ${ }^{49}$ Em termos comparativos, em 1905 os estrangeiros possuíam 20\% dos estabelecimentos rurais produzindo café e apenas $14 \%$ dos pés em cultivo.

Olhando para as regiões do estado de São Paulo, os dados surpreendem. Em 1920, os estrangeiros possuíam a maioria das propriedades cafeeiras na Araraquarense $(58,2 \%)$ e na Paulista (52\%), e em torno de 30\% das propriedades da Mogiana, Noroeste e Alta Sorocabana. Em alguns municípios os imigrantes chegaram a ser donos de mais de $65 \%$ das propriedades cafeeiras - por exemplo, Araraquara (68,2\%), São Bernardo $(71,2 \%)$ e Penápolis $(78,7 \%)$. No que diz respeito aos pés de café, os estrangeiros possuíam 44,4\% dos cafeeiros da Araraquarense, 33\% na Paulista, 22\% na Mogiana e Alta Sorocabana. As propriedades se localizavam principalmente na zona de fronteira, na Alta Sorocabana (30\% do total de propriedades cafeeiras de estrangeiros) e na Araraquarense (30\%), e na zona cafeeira, Mogiana (15\%). Essa concentração das propriedades seguia a mancha cafeeira em 1920 e mostra que os estrangeiros se estabeleceram nas regiões próximas ao café. ${ }^{50}$ Como aponta Thomas Holloway, é preciso levar em conta que em 1923 os filhos dos imigrantes das primeiras levas da imigração em massa podem estar entre os brasileiros proprietários, o que elevaria o

\footnotetext{
${ }^{48}$ Monbeig, Pioneiros; Holloway, Imigrantes; Dean, Rio Claro.

${ }^{49}$ São Paulo, Secretaria da Agricultura, Relatorio apresentado ao presidente do Estado pelo Dr. Heitor Teixeira Penteado, Secretário da Agricultura em 1923 (São Paulo: 1924).

${ }^{50}$ Ibidem.
} 
número de proprietários de origem estrangeira e indicaria uma ascensão econômica e social intergeracional..$^{51}$

\section{Conclusões}

Este capítulo apresentou um panorama da agricultura paulista no início do século $\mathrm{XX}$, enfatizando especificamente as propriedades rurais pertencentes a imigrantes listadas na Estatística Agrícola de 1905, no Censo de 1920 e, complementarmente, em um levantamento das fazendas de café de 1923. Embora existam muitos trabalhos sobre a questão imigratória, assimilação desses imigrantes na sociedade brasileira, seu papel na formação da mão de obra no campo e no meio urbano, muito pouco se escreveu sobre os que se tornaram proprietários de terra. Foram apresentadas informações sobre a presença estrangeira na estrutura fundiária do estado de São Paulo, as características dos estabelecimentos rurais dos imigrantes e sua participação na agricultura do estado no período.

A presença dos estrangeiros entre os proprietários rurais de São Paulo cresceu consideravelmente entre 1905 e 1920, passando de 15,0\% para 27,2\% do total. A análise dos dados mostrou os estrangeiros acompanhando a expansão da fronteira agrícola na aquisição de propriedades e, ao mesmo tempo, também se localizando nas áreas cafeeiras. Em 1920, em algumas regiões como a Noroeste, os estrangeiros chegaram a dominar o cenário rural, possuindo mais de $60 \%$ das propriedades. Os dados de distribuição espacial das propriedades confirmam a presença massiva dos estrangeiros nas regiões onde o café estava consolidado e para onde estava se expandindo, refletindo a pouca atração que as antigas zonas como o Vale do Paraíba e Litoral Norte exerciam para os imigrantes no período.

Em termos de área total, as propriedades pertencentes a estrangeiros possuíam, em média, metade do tamanho das propriedades de brasileiros. As pequenas e médias propriedades, em 1905, somava quase $93 \%$ do total das propriedades dos estrangeiros. Em relação à área cultivada, os estrangeiros faziam um uso mais intenso de suas terras, cultivando, em média, $18,3 \%$ da área de suas propriedades, enquanto os nacionais cultivavam apenas $12,5 \%$. Os estrangeiros dedicavam maiores parcelas das terras para os cultivos tanto do café quanto de bens voltados para a alimentação em comparação com os brasileiros. Além da área em cultivo, como notado, ser maior nos

\footnotetext{
${ }^{51}$ Holloway, Imigrantes, 234-6.
} 
estabelecimentos pertencentes a estrangeiros, a área considerada imprestável e em capoeira era menor do que comparada à dos nacionais.

A presença massiva de propriedades pequenas e médias entre os estrangeiros proprietários, no entanto, não significou uma distribuição mais equitativa da terra. Essas duas categorias dominavam apenas $33 \%$ da área total e $56 \%$ da área cultivada pelos imigrantes. Os poucos estrangeiros que figuram no quadro de grandes proprietários e donos de latifúndios no estado controlavam mais de $40 \%$ da área total, ainda que cultivassem apenas $16 \%$ do total da área plantada. O coeficiente de Gini atingiu o valor de 0,789 para todas as propriedades de estrangeiros em São Paulo. Surpreendentemente, um cálculo de Gini levando em conta apenas as propriedades dos brasileiros indica um coeficiente menor, de 0,776 , que o encontrado para as propriedades de estrangeiros.

Em termos de produção, os estrangeiros em 1905 foram responsáveis por 15\% da produção cafeeira do estado, $12 \%$ de todo o milho, $14,5 \%$ do feijão e $17,5 \%$ do arroz. Os dados revelaram também que $40 \%$ de toda a cana de açúcar produzida no estado vieram das propriedades estrangeiros. Em 1923, um levantamento do Ministério da Agricultura mostrou que 30\% dos pés de café do estado se encontravam em propriedades pertencentes a estrangeiros e que estas constituíam $40 \%$ dos estabelecimentos rurais produzindo café, demonstrando uma participação de destaque em produtos importantes

Nos 15 anos entre 1905 e 1920 analisados neste capítulo nota-se a consolidação dos estrangeiros que se tornaram proprietários e sua crescente importância na participação da agricultura paulista. À época do primeiro levantamento censitário das propriedades rurais em 1905, o estado de São Paulo já vinha recebendo imigrantes em massa há quase 20 anos. Nesse período, mais de um milhão de imigrantes, na sua grande maioria vindos para o trabalho no campo, espalharam-se pelo interior do estado. Nos 15 anos seguintes o estado recebeu mais 600 mil estrangeiros. No próximo capítulo serão analisados quem foram os imigrantes que se tornaram proprietários de terra em São Paulo. 


\section{CAPÍTULO 4 - OS IMIGRANTES PROPRIETÁRIOS RURAIS EM SÃO PAULO NO COMEÇO DO SÉCULO XX}

Em 1912, quarenta e sete fazendeiros do município de São Carlos escreveram uma petição endereçada ao Secretário de Agricultura de São Paulo solicitando o incentivo à imigração japonesa para o estado. O motivo era um tanto insólito: o sucesso dos imigrantes europeus. Segundo os fazendeiros, o "enriquecimento" dos colonos antigos, fruto dos "bons salários que ganharam na fazenda cafeeira", havia tornado possível sua tão almejada ascensão à condição de proprietário de terra. Esses imigrantes não só estariam deixando de ofertar sua mão de obra para os cafeicultores paulistas como também passavam eles mesmos a demandar trabalho para suas propriedades, fatos que concorriam para levar à escassez de braços para o café. Os fazendeiros deixaram claro, contudo, "como bons paulistas" que eram, o orgulho que sentiam ao ver essa transformação na fazenda cafeeira, que vinha "mais uma vez demonstrar que no nosso rico e poderoso estado, quem trabalhar e for econômico no fim de alguns anos está habilitado a ver transformada a sua posição de trabalhador para a de proprietário". ${ }^{1}$

Como visto em capítulos anteriores, o ideal de uma vida melhor levou centenas de milhares de imigrantes a deixar suas terras natais em direção ao Brasil e outras partes das Américas nos séculos XIX e XX. Dentre outras motivações, econômicas ou não, tornar-se proprietário de terras era o principal fator de atração dos imigrantes. A questão que permanece, contudo, é em que medida essas aspirações foram efetivamente alcançadas no caso desses imigrantes para São Paulo. Até que ponto o cenário traçado pelos fazendeiros são-carlenses era real?

Não existe consenso entre os estudiosos da imigração para São Paulo sobre a mobilidade social dos imigrantes da condição de colonos para proprietários de terra. Alguns autores relacionam o acesso dos imigrantes à terra com as crises pelas quais passou a economia cafeeira, que teriam levado grandes fazendeiros a fragmentarem e venderem parte de suas propriedades. ${ }^{2}$ Outros questionam se as condições de trabalho

\footnotetext{
1 São Carlos, Representação a favor da imigração japonesa, 1912, Fundo Secretaria da Agricultura, Acervo APESP, cx. 3.7.1435, doc. 25.

2 Stolcke, Cafeicultura; Prado Jr., "Distribuição da propriedade"; Monbeig, Pioneiros. Milliet observou contemporaneamente esse fenômeno em diversos municípios paulistas na década de 1930, com o surgimento de pequenas propriedades em municípios mais antigos como Campinas, Sorocaba, Atibaia e Bragança. Milliet, "O desenvolvimento," 87-9; Cánovas, analisando os registros de terras de Vila Novaes,
} 
nas fazendas teriam permitido a ascensão socioeconômica de número expressivo de imigrantes pobres. Autores mais otimistas destacam a liberdade que famílias imigrantes tinham dentro das fazendas de café para cultivar pequenas roças em terrenos cedidos pelos fazendeiros. Essa cultura complementar de alimentos teria sido essencial para os imigrantes acumularem recursos e comprarem terras posteriormente. ${ }^{3}$ Outros autores adotam uma visão mais pessimista: as condições de trabalho nas fazendas, o preço médio das terras e a capacidade do imigrante em acumular pecúlio não os permitiriam acesso à terra em um prazo razoável. Sob esta ótica, estrangeiros que conseguiram adquirir propriedades já teriam vindo com algum capital ou teriam se instalado nas sedes dos municípios por um período de tempo antes de retornarem ao meio rural. ${ }^{4}$

Que pouco a pouco pelo menos parte dos imigrantes foi se estabelecendo como proprietários de terras no interior de São Paulo é um fato demonstrado pelas estatísticas. Como visto no Capítulo 3, se em 1905 15\% das propriedades rurais pertenciam a estrangeiros, em 1920 esse percentual subiu para mais de 27\%. Alguns municípios do estado chegaram a ter os estrangeiros como maioria dos donos de estabelecimentos rurais. No entanto, quem foram então os estrangeiros que adquiriram essas terras? Foram os colonos transportados com subsídios do governo para o trabalho nas fazendas que, após um tempo, conseguiram acumular pecúlio suficiente? Foram os que se dedicaram ao trabalho no meio urbano? Ou foram aqueles imigrantes espontâneos que já chegavam com alguma poupança de seus países de origem? Este capítulo busca indicar possíveis caminhos para responder a essas questões.

\subsection{Identificando os imigrantes proprietários}

Informações estatísticas individuais registradas ao longo do tempo oferecem evidências valiosas em temas como assimilação de imigrantes, mobilidade socioeconômica e intergeracional na análise histórica. ${ }^{5}$ No entanto, encontrar um

mostra que a prática de subdivisão de grandes propriedades também ocorria no meio da região cafeeira do estado e durante o período de alta produção. Cánovas, "A emigração,” 236.

${ }^{3}$ Holloway, Imigrantes; Font, "Changing"; Boris Fausto, Historiografia da imigração para São Paulo (São Paulo: Sumaré/FAPESP, 1991).

${ }^{4}$ Hall, "Origins"; Bassanezi, Fazenda; Dean, Rio Claro; José de Souza Martins, O cativeiro da terra (São Paulo: Contexto, 2010); Stolcke, Cafeicultura, 78-80.

5 Como exemplos de trabalhos usando cruzamento de dados históricos pode-se citar: Abramitzky, Boustan e Eriksson, "Europe's"; Abramitzky, Boustan e Eriksson, "Have the poor"; Abramitzky, Boustan e Eriksson, "A Nation of Immigrants"; Jason Long e Joseph Ferrie, "Intergenerational occupational mobility in Great Britain and the United States since 1850," The American Economic Review 103 (2013): 1109-37; Laura Salisbury, "Selective migration, wages, and occupational mobility in nineteenth century America," Explorations in Economic History 53 (2014); James J. Feigenbaum, "Intergenerational 
mesmo indivíduo em duas ou mais bases de dados diferentes sem um identificador comum - como um número de passaporte ou de registro civil - representa um grande desafio para análise. Erros de transcrição, mudanças nas grafias e ocorrência de homônimos dificultam a tarefa de encontrar a correspondência exata entre fontes de dados distintas, independentemente do método utilizado. Recentemente, historiadores econômicos vêm utilizando diferentes métodos para automatizar essa tarefa e minimizar os possíveis erros e inconsistências. ${ }^{6}$

Os trabalhos que buscam encontrar indivíduos em bases distintas sugerem que um bom método de associação deve satisfazer quatro critérios: 1) acurácia, gerando o mínimo de falsos positivos possível; 2) eficiência, criando o máximo de correspondências verdadeiras possível; 3) representatividade, ou seja, deve criar uma amostra que represente o mais fielmente possível a população de interesse; e 4) replicabilidade para que pesquisadores possam implementá-lo mesmo em situações de recursos computacionais limitados. ${ }^{7}$ Neste capítulo, emprega-se um método que buscou contemplar essas recomendações e atender aos objetivos propostos.

\subsubsection{Realizando o matching entre as bases de dados}

O principal objetivo deste capítulo é identificar quem eram os imigrantes que adquiriram terras no estado de São Paulo no início do século XX. Para tanto, foi feito o cruzamento dos nomes de proprietários agrícolas estrangeiros listados na Estatística Agrícola de 1905 com os registros de matrícula de imigrantes da Hospedaria de Imigrantes de São Paulo. Uma vez que são duas bases inteiramente distintas, sem um identificador individual comum, as informações de nome, nacionalidade e data de entrada na Hospedaria foram utilizadas para identificar os imigrantes. Esse método está sujeito a erros e resultados não-únicos (ou seja, mais de um resultado para uma busca de um determinado nome). Para contornar esse problema e ter o maior número possível de

Mobility during the Great Depression," Working Paper (2015); James J. Feigenbaum, "Multiple Measures of Historical Intergenerational Mobility: Iowa 1915 to 1940," Economic Journal 128, n. 612 (2018); Pérez, "The (South)"; Pérez, "Intergenerational"; William J. Collins e Marianne H. Wanamaker, "Up from Slavery? African American Intergenerational Economic Mobility Since 1880," NBER Working Paper No. 23395 (May 2017); Monasterio e Lopes, "Brasil sem imigrantes".

${ }^{6}$ Ron Goeken et al, "New Methods of Census Record Linking," Historical Methods 44, n. 1 (jan./mar. 2011): 7-14; James J. Feigenbaum, “A Machine Learning Approach to Census Record Linking,” Working Paper (March 28, 2016); Ran Abramitzky, Roy Mill e Santiago Pérez, "Linking Individuals Across Historical Sources: a Fully Automated Approach," Historical Methods (2019); Ran Abramitzky et al, “Automated Linking of Historical Data," NBER Working Paper No. 25825 (Jun. 2020).

7 Abramitzky et al, "Automate," 2; Abramitzky, Mill and Pérez, "Linking," 2-3. 
resultados verdadeiros, diante das restrições impostas pelas bases de dados, adotou-se um método semiautomático de correspondência dos dados, conforme detalhado abaixo. Optou-se também por não incluir imigrantes portugueses na amostra justamente pela existência de grande número de homônimos e, por consequência, resultados não-únicos que impossibilitam a correspondência (matching) verdadeira. ${ }^{8}$

Para a realização do método semiautomático de correspondência, foram criadas duas bases de dados paralelas. Uma contém os registros de matrícula da Hospedaria de Imigrantes e a outra os registros dos proprietários estrangeiros listados na Estatística Agrícola de 1905. Primeiro, selecionaram-se as variáveis identificadoras. No caso, as únicas variáveis possíveis são nome e nacionalidade - as únicas comuns aos dois bancos de dados - e as datas dos registros da Hospedaria de Imigrantes. Em seguida, para simplificar, optou-se por comparar apenas os indivíduos que se enquadrassem em determinadas "variáveis de bloqueio", isto é, aquelas para as quais os erros são muito improváveis - por exemplo: indivíduos raramente informam errado sua nacionalidade, de forma que seria improvável deixar passar um matching positivo ao considerar indivíduos que declararam diferentes nacionalidades. ${ }^{9}$

O passo seguinte foi criar, para cada indivíduo em cada uma das bases, uma lista ordenada contendo todas as palavras do nome. Em seguida, para mapear similaridades na grafia dos nomes nessas listas em uma distância numérica, usou-se a medida de distância contínua de strings (conjunto de caracteres) de Jaro-Winkler, que foi especificamente criada para comparar nomes, sendo desenvolvida em um contexto de correspondência de registros. ${ }^{10}$ A medida Jaro-Winkler calcula uma função do número de caracteres que coincidem e que requerem uma transposição entre os dois strings que se estão comparando. A medida varia de 0 (nenhum caractere coincide) a 1 (todos os caracteres coincidem). Para cada palavra na base da Estatística Agrícola de 1905, computa-se a pontuação de Jaro-Winkler em relação a todas as palavras na base da Hospedaria de Imigrantes de São Paulo. Após estimar a probabilidade de que cada par de indivíduos fosse uma correspondência verdadeira, definiu-se uma pontuação mínima

\footnotetext{
${ }^{8}$ Os termos "correspondência" e "matching" serão utilizados como equivalente daqui em diante.

9 Abramitzky, Mill e Pérez, "Linking," 6-7. É possível que tenham havido casos em que a nacionalidade anotada pelo agente de imigração não condizia com a nacionalidade do imigrante, o que pode ter ocorrido, por exemplo, com alguns austríacos oriundos da região do Tirol italiano. Por falarem italiano, alguns desses imigrantes foram registrados como sendo de nacionalidade italiana. Ainda assim, é a melhor forma de bloqueio possível que foi encontrada.

10 String é qualquer sequência ordenada de caracteres, que correspondem a números, letras ou símbolos. Utilizou-se a distância contínua de Jaro-Winkler nos moldes de Abramitzky, Mill e Pérez, "Linking," 3.
} 
para escolher qual correspondência usar na análise. No caso, adotou-se 0,8 como a pontuação mínima aceitável. Ou seja, a correspondência adotada foi bastante elevada, uma vez que o índice varia de 0 a 1, como mencionado. Para cada nome da Estatística Agrícola de 1905 obteve-se, assim, as correspondências na base da Hospedaria, até um máximo de 20 matchings. Dessa forma, realizou-se um mapeamento no qual para cada proprietário estrangeiro da Estatística Agrícola de 1905 há uma lista com possíveis matchings dos registros da Hospedaria. Por fim, realizou-se uma verificação manual dos resultados a fim de definir se e qual dos possíveis resultados seria a correspondência mais provável para aquele determinado indivíduo.

Fazer a verificação final das correspondências manualmente implica alguns problemas. O mais importante talvez seja a questão da replicabilidade do método, uma vez que este depende de certo grau de subjetividade na escolha da correspondência verdadeira. Apesar desse problema, a condição dos dados impede, de qualquer forma, a automatização completa do processo. A título de ilustração, um imigrante que saía da Hospedaria para uma determinada localidade pode ter adquirido propriedades rurais em outras localidades completamente diferentes. Essa diferença entre o destino do imigrante e o local onde comprou terras não permite, por exemplo, usar o local de destino do imigrante no processo de correspondência das bases. $\mathrm{O}$ abrasileiramento dos nomes dos proprietários rurais na Estatística Agrícola de 1905 é outro empecilho para o matching e requer verificação manual dos resultados do processo empreendido. De toda forma, nenhum método é capaz de alcançar acurácia perfeita. ${ }^{11}$

A Tabela 4.1 abaixo apresenta os resultados obtidos da correspondência aqui descrita anteriormente. Como pode se observar, o procedimento de matching produziu uma amostra final com 652 proprietários rurais estrangeiros de um universo de 6.144. Os números variaram consideravelmente entre as nacionalidades. Enquanto foi possível mapear apenas 3,3\% dos alemães e aproximadamente 10\% dos italianos, localizaram-se na Hospedaria 32\% dos espanhóis e 27\% dos austríacos donos de terra em 1905.

\footnotetext{
11 Ao testarem diversos métodos automatizados para realizarem a correspondência de duas versões distintas de transcrição do Censo Norte-Americano de 1940, Abramitzky et al. mostraram que entre 7 e $14 \%$ dos nomes e 17 e $32 \%$ dos sobrenomes tinham problemas de transcrição e que mesmo tentando linkar um censo a ele mesmo só foi possível localizar entre 43 e $67 \%$ das observações. Esses resultados decorrem da qualidade da transcrição e pela existência de nomes comuns, que tornam difícil encontrar seu match verdadeiro. Abramitzky et al, "Automate," 5-6.
} 
Tabela 4.1 - Amostra resultante do processo de matching, por nacionalidade (estado de São Paulo, 1905)

\begin{tabular}{cccc}
\hline Nacionalidade & $\begin{array}{c}\text { Total de proprietários } \\
\text { rurais em 1905 }\end{array}$ & $\begin{array}{c}\text { Total de proprietários } \\
\text { localizados }\end{array}$ & $\begin{array}{c}\text { Taxa de localizados, em } \\
\%\end{array}$ \\
\hline Italianos & 4.804 & 469 & 9,8 \\
Espanhóis & 411 & 132 & 32,1 \\
Austríacos & 89 & 24 & 27,0 \\
Alemães & 636 & 21 & 3,3 \\
Franceses & 55 & 1 & 1,8 \\
Belgas & 24 & 1 & 4,2 \\
Suecos & 10 & 2 & 20,0 \\
Dinamarqueses & 9 & 1 & 11,1 \\
Suíço & 31 & 1 & 3,2 \\
Turcos & 26 & 0 & 0,0 \\
Norte Americano & 38 & 0 & 0,0 \\
Sírios & 11 & 0 & 0,0 \\
\hline Total & 6.144 & 652 & 10,6
\end{tabular}

Fonte: São Paulo, Estatística Agrícola. Registro de Matrícula da Hospedaria de Imigrantes, Memorial do Imigrante, Arquivo Público do Estado de São Paulo.

Os valores resultantes do procedimento adotado que são apresentados na Tabela 4.1 acima estão subestimados. A questão dos homônimos no mesmo grupo de entrada na Hospedaria acabou resultando em falsos positivos, isto é, mais de uma correspondência na Hospedaria a um proprietário na Estatística Agrícola. Na verificação manual dos resultados, adotou-se um procedimento mais conservador e foram descartadas todas as observações em que não foi possível determinar a correspondência verdadeira. Tal problema foi particularmente recorrente para os espanhóis e italianos. Os falsos positivos observados quase dobrariam a amostra obtida e o matching final teria sido da ordem de aproximadamente $20 \%$ do total de proprietários estrangeiros listados em 1905. Portanto, ainda que a correspondência aqui obtida seja de 10,6\% do total de proprietários estrangeiros no estado de São Paulo em 1905, pode-se supor que os dados são representativos da realidade devido à cautela na consideração e descarte dos falsos positivos. Na próxima seção, serão apresentados os resultados gerais do procedimento de matching e os resultados por nacionalidades.

\subsection{Resultados da correspondência entre as bases de dados}

A década de 1890 foi o período com maior entrada de estrangeiros durante toda a época da grande imigração no estado de São Paulo, assim como foi o período com 
maior número de imigrantes que se tornaram proprietários rurais. Na amostra obtida pelo matching entre as bases de dados da Hospedaria de Imigrantes de São Paulo e da Estatística Agrícola de 1905 descrito na seção anterior, 70\% dos proprietários mapeados passaram pela Hospedaria entre 1890 e 1899, com dois anos se destacando: 1891, com $20 \%$ e 1895, com $11 \%$. Poucos foram os proprietários estrangeiros mapeados que passaram pela Hospedaria muito no início da série de registros, ou seja, antes de 1890, ou muito tarde, depois de 1900 e antes de 1904. Apenas 9\% dos imigrantes identificados chegaram a São Paulo entre 1884 a 1887 e menos de 6\% o fizeram após 1900. Esses dados corroboram o notado por observadores, viajantes e na literatura: o tempo médio para um imigrante adquirir terras trabalhando como colono nas fazendas girava em torno de dez anos. ${ }^{12} \mathrm{O}$ número de proprietários localizados nos registros da Hospedaria diminuiu significativamente após 1900, indicando que imigrantes que conseguiram comprar terras não o fizeram logo após sua chegada a São Paulo.

Dentre os imigrantes proprietários localizados, a vasta maioria $(90,8 \%)$ era de homens listados como chefes de família nos registros da Hospedaria. Ou seja, eram imigrantes com esposa e filhos ou ao menos com algum outro familiar. Esse resultado também corrobora as afirmações de que o imigrante com família, com todos os membros aptos ao trabalho no campo, teria mais facilidade de acumular pecúlio e adquirir terras. ${ }^{13}$ Apenas $1 \%$ dos mapeados foi registrado como filhos, mostrando que, em 1905, talvez ainda fosse cedo para se falar em ascensão social significativa dos descendentes dos estrangeiros chegados ao estado durante a imigração em massa. As mulheres praticamente não tiveram representação entre os proprietários estrangeiros mapeados, pois foram encontradas apenas duas no procedimento de correspondência realizado. ${ }^{14}$

Com relação à ocupação dos imigrantes, não há informação para 333 dos 652 proprietários encontrados na amostra após o matching. Agricultores, camponeses e lavradores correspondiam a $41 \%$ do total. Além desses, havia também jornaleiros

\footnotetext{
${ }^{12}$ Louis Albert Greffé, Visions du Brésil (São Paulo: Francisco Alves e Cia, 1912), 267; Dean, Rio Claro; Bassanezi, "Fazenda," 272.

${ }^{13}$ Greffe, Visions, 267; Belli, “A Italia”; Stolcke, Agricultura, 20, Holloway, Imigrantes, 214.

${ }^{14}$ Vidal Luna, Herbert Klein e William Summerhill mostraram que em 1905 apenas 6\% dos proprietários rurais do estado eram mulheres, muitas das quais herdeiras de propriedades já consolidadas. Vidal Luna, Herbert Klein e William Summerhill, “A agricultura paulista em 1905,” Estudos Econômicos 44, n. 1 (jan./mar. 2014): 165, 175. Sobre o papel da mulher imigrante na agricultura cafeeira, ver: Maria Izilda dos Santos Mattos, Oswaldo Truzzi, Carla F. Conceição, "Mulheres imigrantes: presença e ocultamento (interiores de São Paulo, 1880-1930)," Revista Brasileira de Estudos Populacionais 35, n. 3 (2018).
} 
$(6,2 \%)$, carpinteiros $(0,3 \%)$, jardineiros $(0,3 \%)$ e profissões urbanas, como alfaiates, oleiros, ferreiros e sapateiros, embora correspondendo a apenas $0,1 \%$ do total. Até 1900 a política de imigração paulista tendeu a ser mais rígida, significando que apenas os imigrantes agricultores e aptos para o trabalho nas fazendas receberiam o auxílio, o que leva a crer que, apesar de não termos dados de ocupação para metade dos proprietários aqui analisados, estes também eram em sua grande maioria agricultores. A hipótese levantada por parte da literatura de que a maioria dos imigrantes que adquiriram terras não haviam sido os chegados para o trabalho no campo não parece se sustentar na amostra aqui apresentada.

Entre os imigrantes proprietários localizados, apenas 9,5\% chegaram ao estado de São Paulo de forma espontânea entre 1884 e 1904. Outros 15\% vieram com auxílio do governo estadual, mais $21 \%$ por conta do governo geral e $10 \%$ sob auspício da Sociedade Promotora de Imigração. Não consta informação sobre a forma de chegada, se espontânea ou subsidiada, para $47 \%$ dos proprietários mapeados, mas parece provável que a maioria era também de imigrantes subsidiados, especialmente no período de 1886 a 1904, quando a imigração espontânea ainda era baixa. ${ }^{15}$ Se se recordar que a política de subsídios posta em prática pela Sociedade Promotora de Imigração e pelo governo de São Paulo preferia imigrantes pobres e sem recursos, pode-se supor que, ao menos na amostra obtida com o matching, há sinais de ascensão socioeconômica desses colonos, como será visto a seguir. ${ }^{16}$

A maioria das unidades agrícolas da amostra - 496 ou 76,7\% do total - era pequena propriedade, com menos de 25 alqueires. Essas propriedades controlavam pouco menos de $28 \%$ da terra da amostra. Com exceção de 27 dessas propriedades, todas estavam em cultivo, sendo o café produzido em metade delas. ${ }^{17}$ As culturas alimentares também tinham espaço na área cultivada desses pequenos proprietários. Milho era cultivado em 326 das 496 propriedades, arroz em 145 delas, feijão em 200, e batatas, mandioca, legumes em 80 propriedades. Outras 117 unidades - 18\% do total eram médias propriedades (entre 25 e 100 alqueires), controlando $32 \%$ da terra da

\footnotetext{
15 Thomas Holloway mostra, através dos dados divulgados pelos Anuários Estatísticos do Estado, que entre 1893 e 1900 os imigrantes subvencionados correspondiam a mais de $90 \%$ das entradas na Hospedaria. Holloway, Imigrantes, 90-1.

16 Ver Capítulo 1 para as discussões sobre as políticas de atração de imigrantes implementadas em São Paulo.

${ }^{17}$ Essas 27 propriedades sem cultivo podem ter sido terras recém-adquiridas por ocasião da Estatística Agrícola de 1905 ou talvez de imigrantes que já conseguiram comprar terras esperando valorização futura.
} 
amostra. Todas estavam em cultivo, com o café presente em $75 \%$ delas. Somente $29-$ ou 4,4\% da amostra - eram de grandes propriedades (100 a 500 alqueires), que, apesar do baixo número, ocupavam $40 \%$ da terra. Apenas quatro dessas grandes propriedades eram incultas, sendo as outras dominadas pela produção cafeeira e de alimentos. Havia um único latifúndio (maior do que 500 alqueires), de 700 alqueires, com uma área cultivada de 42 alqueires dedicados à produção de café. A amostra apresenta mais terra ocupada por pequenas propriedades $(29,7 \%)$ do que o observado no Capítulo 3 para o conjunto total de propriedades estrangeiras no estado de São Paulo, onde os pequenos proprietários possuíam apenas $13 \%$ da terra e os grandes proprietários e latifundiários controlavam $67 \%$ das terras.

A mobilidade geográfica dos imigrantes também pode ser retratada na amostra. Entre os estrangeiros mapeados, 95\% deles obtiveram terras em municípios diferentes dos quais se dirigiram inicialmente para o trabalho na fazenda. Se observada a agregação por regiões onde os imigrantes dirigiram-se primeiramente como colonos e onde se estabeleceram como proprietários, os dados retratam uma mobilidade um pouco menor: $77 \%$ dos imigrantes que adquiriram terras mudaram de região no estado de São Paulo. O heatmap abaixo ilustra esses deslocamentos (Figura 4.1).

Pela Figura 4.1 abaixo nota-se que a Araraquarense foi a principal localidade onde os estrangeiros adquiriram terras, 77 dos 275 casos observados. Boa parte dos imigrantes que foram como colonos para as zonas vizinhas - em especial a Paulista e Mogiana - tornaram-se proprietários de terra na região da Araraquarense. Dos imigrantes da amostra que se dirigiram para a região da Paulista após a saída da Hospedaria, 36\% (26) adquiriram terras na Araraquarense. Em comparação, apenas $20 \%$ (15) dos que foram para a Paulista adquiriram terras na própria região. Dos imigrantes mapeados que foram para a Mogiana se dirigiram após saírem da Hospedaria, $21 \%$ (14) compraram terras na Araraquarense e 19\% (13) se tornaram proprietários na própria Mogiana. Aqueles imigrantes que saíram da Hospedaria para trabalhar nas fazendas nos municípios da Araraquarense parecem ter encontrado mais facilidade para permanecerem na mesma região, visto que a maioria (14 ou 60\%) não migrou para outras localidades para se fixarem como proprietários. Dos colonos que trabalharam na Capital, 23\% (14) preferiram adquirir terras na Araraquarense. A exceção nessa amostra são os colonos que haviam ido para as fazendas da zona Central, 
que buscaram comprar terras na própria Central (12 ou $40 \%$ deles) ou na vizinha Mogiana (9 ou 22,5\%).

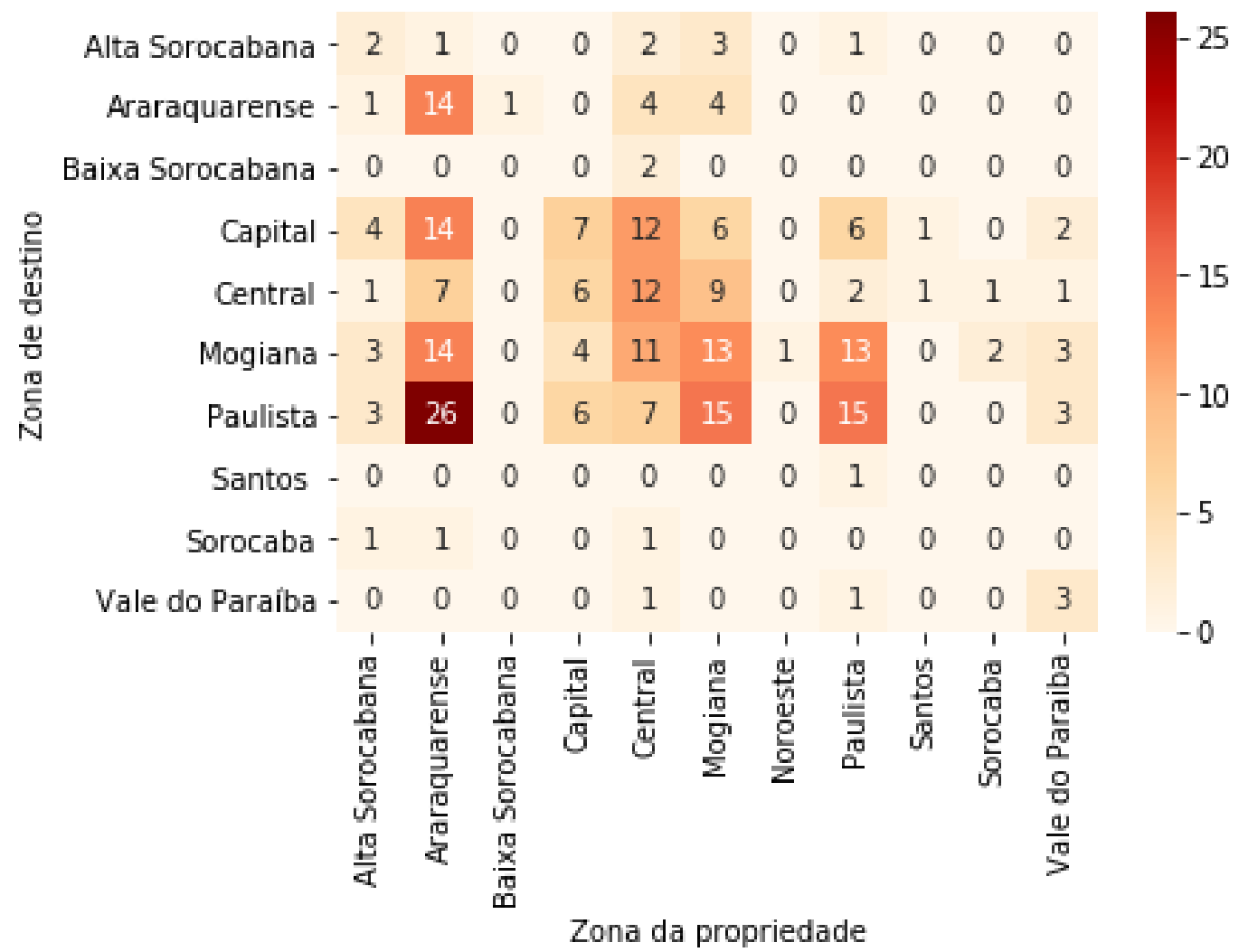

Figura 4.1 - Heatmap de localização inicial e localização das propriedades de imigrantes, por zona de São Paulo, 1905.

Nota: Esse mapa foi criado com informações de 275 imigrantes proprietários para os quais existem registros da localidade para onde foram como colonos e da localidade da propriedade adquirida.

Fontes: São Paulo, Estatística Agrícola; Registro de Matrícula da Hospedaria de Imigrantes, Memorial do Imigrante, Arquivo Público do Estado de São Paulo.

Nos quase vinte anos entre os primeiros registros na Hospedaria e a Estatística Agrícola de 1905 pode-se supor que, para uma parcela expressiva dos imigrantes, tornou-se viável que adquirissem propriedades pequenas, nos municípios das zonas de fronteira agrícola, em especial da Araraquarense, após alguns anos de trabalho nas fazendas. Porém, o panorama geral dos resultados obtidos com o matching modifica-se quando se observam as nacionalidades em separado. A eguir, serão analisados os resultados para os italianos, espanhóis, alemães e austríacos. Essas quatro nacionalidades representam $80 \%$ do total de propriedades de estrangeiros recenseadas em 1905 e 99\% dos proprietários encontrados na correspondência descrita anteriormente. 


\subsubsection{Os Italianos}

Os italianos foram a principal nacionalidade em trânsito pela Hospedaria de Imigrantes de São Paulo entre 1884 e 1904. Nesses vinte anos, mais de 521.000 imigrantes italianos - representando $73 \%$ do total de imigrantes - foram registrados na Hospedaria e empregaram-se nas fazendas paulistas. Foram também, em termos de números, os principais proprietários estrangeiros no estado de São Paulo registrados na Estatística Agrícola de 1905, sendo donos de 4.823 propriedades rurais - equivalente a $62 \%$ das propriedades de estrangeiros e $10 \%$ do total de propriedades rurais do estado. A amostra do matching retornou uma correspondência de 9,8\% entre os proprietários listados na Estatística Agrícola e os italianos recebidos pela Hospedaria.

A área média das propriedades dos italianos na amostra era de 23 alqueires. Das 463 propriedades encontradas na correspondência feita, $80 \%$ eram pequenas, $16 \%$ médias, 3,6\% grandes e 0,2\% latifúndios. Os italianos em geral se fixaram nas áreas de fronteira e nas regiões cafeeiras já em declínio, especialmente os pequenos proprietários. Aproximadamente $25 \%$ das pequenas propriedades se encontravam na Araraquarense, $21 \%$ na Central e $10 \%$ na Capital. A Mogiana mostrou-se uma área viável para os italianos se estabelecerem, tendo $17 \%$ dos pequenos e $40 \%$ dos grandes proprietários, sendo a região onde se identificou o único latifúndio da amostra. As médias propriedades da amostra localizaram-se principalmente na Araraquarense (40\%), região de fronteira agrícola, na região cafeeira da Mogiana (19\%) e na Central (16\%), onde o café já vinha perdendo importância em 1905. A Tabela 4.2 abaixo apresenta esses dados. 
Tabela 4.2 - Tamanho e localização das propriedades mapeadas dos italianos no estado de São Paulo, por região, 1905

\begin{tabular}{ccccc}
\hline & Pequenas & Médias & Grandes & Latifúndios \\
\hline Capital & 39 & 2 & & \\
Vale do Paraíba e Litoral Norte & 20 & 1 & 1 & \\
Sorocaba & 4 & 1 & 1 & \\
Central & 79 & 12 & 1 & \\
Mogiana & 66 & 11 & 3 & \\
Paulista & 42 & 29 & 3 & \\
Araraquarense & 96 & 2 & & \\
Noroeste & 1 & 2 & & \\
Alta Sorocabana & 23 & & & \\
Baixa Sorocabana & 1 & & & \\
Santos e Litoral Sul & 1 & & & \\
\hline
\end{tabular}

Fonte: São Paulo, Estatística Agrícola. Registro de Matrícula da Hospedaria de Imigrantes, Memoria do Imigrante, Arquivo Público do Estado de São Paulo.

Alguns observadores e viajantes da época parecem ter nutrido uma visão otimista da situação dos colonos italianos em São Paulo. A opinião por eles manifestada era que a vida nas fazendas oferecia melhores condições financeiras e sociais do que as existentes no país de origem e, durante a alta do café, havia facilidade de lucro e oportunidades para acúmulo de pecúlio. ${ }^{18}$ Outro ponto frequentemente afirmado era que "um pouco de boa vontade", "uma vida modesta" e o trabalho duro seriam suficientes para o imigrante ascender socialmente em um período de tempo não muito longo. ${ }^{19}$

O sucesso do colono italiano em solo paulista foi tema de diversos relatórios ministeriais e consulares e reportagens de contemporâneos. Nesses documentos, exaltava-se a perseverança do lavrador imigrante e os frutos de seu trabalho aparecendo na forma de pequenas propriedades espalhadas pelo estado. Antonio Piccarolo, historiador e jornalista socialista, por exemplo, relatou que conduziu um inquérito em 1913 visando avaliar a situação dos italianos colonos no estado. As "numerosíssimas respostas" que obteve, dizia o autor, haviam sido unânimes em afirmar que "os numerosos italianos proprietários de terras (...) eram todos ex-colonos" e que entre os colonos que preferiram não regressar à Itália havia a tendência de se tornarem pequenos

\footnotetext{
18 Antonio Piccarolo, “As condições econômicas do Imigrante,” Correio Paulistano, 28/01/1913, 3; Louis Albert Greffé, viajante francês, afirmou que "vindo então uma família ou um agrupamento de famílias com uma pequena reserva de capital e uma vontade de trabalho sobre as aptidões e os gostos pela cultura, é moralmente certo que eles encontrarão no Brasil, e particularmente no estado de São Paulo, as condições de sucesso que poucos países de colonização podem oferecer”. Greffé, Visions, 267.

${ }^{19}$ Antonio Piccarolo, “As condições,” 3; Greffé, Visions, 272. Pio di Savoia, "Lo stato,” 210.
} 
proprietários. ${ }^{20}$ B. Belli, Ministro das Relações Exteriores da Itália, observou em seu relatório acerca da imigração italiana nos anos de 1909 e 1910 que as condições dos italianos que haviam adquirido terras em São Paulo eram "plenamente satisfatórias" do ponto de vista moral, econômico ou de posição social e que não era "pequeno o número dos bons colonos que, em períodos de tempo não muito longos, poderiam chegar a condições que lhes permitissem adquirir terras". Uma família numerosa, composta de alguns membros aptos ao trabalho agrícola, conseguiria uma remuneração suficiente para seu sustento e para poupança, embora famílias formadas apenas de marido, mulher e filhos de pequena idade poderiam sofrer privações. ${ }^{21}$

Alfredo Ellis Jr., em seu trabalho sobre a população do estado de São Paulo, ao tratar dos imigrantes afirmou que os italianos, especialmente os da do pré-Primeira Guerra Mundial, haviam todos sido assimilados na economia e sociedade paulistas: "Vieram paupérrimos e em 20, 30, ou 40 anos subiram na roda da fortuna, à custa de mil capítulos de tenacidade, de privações, de sacrifícios, de inteligência e de economia. Hoje (...) são proprietários e muitos deles, hoje velhos patriarcas, que vieram meninos há vários decênios, são até respeitáveis coronéis no nosso interior e chefes políticos influentes moldados à feição paulista". ${ }^{22}$

A historiografia recente não apresenta consenso com relação ao destino dos imigrantes como proprietários. Michael Hall, por exemplo, valendo-se dos boletins oficiais do governo italiano e também de relatos de viajantes contemporâneos, afirmou que os salários defasados, as péssimas condições a que eram submetidos e o alto custo de vida seriam um impedimento para o imigrante italiano conseguir acumular poupança. Apenas em circunstâncias especiais algum pecúlio era alcançado e seria necessário que o imigrante viesse em uma família numerosa e composta por membros em idade ativa para que todos pudessem contribuir para a renda familiar. Esses imigrantes deveriam também se estabelecer em fazendas localizadas próximas das sedes dos municípios, o que os desvincularia da necessidade de adquirir bens no armazém da fazenda e proporcionaria condições para a venda de gêneros alimentícios no meio urbano. Para o autor, os resultados da Estatística Agrícola de 1905 seriam um retrato do fracasso da capacidade do imigrante adquirir terras. ${ }^{23}$

\footnotetext{
${ }^{20}$ Antonio Piccarolo, "As condições," 3.

${ }^{21}$ B. Belli, “A Itália e a Imigração," Correio Paulistano, 02/07/1911, 4.

${ }^{22}$ Ellis Jr., Populações, 153.

${ }^{23}$ Hall, "Origins," 146-50, 180-1.
} 
Thomas Holloway, por sua vez, não negou as péssimas condições de vida e trabalho e dificuldades às quais os colonos italianos muitas vezes estavam submetidos. No entanto, o autor afirma que agentes consulares, viajantes e observadores, ao mesmo tempo em que relatavam os abusos, também descreveram que muitos conterrâneos conseguiram ascender econômica e socialmente trabalhando nas fazendas de café. Para o autor, grande parte dos imigrantes que se tornaram fazendeiros muito provavelmente começaram como colonos, já que o trabalho no café era virtualmente o único emprego rural disponível e os que tiveram sucesso no meio urbano provavelmente não se tornariam fazendeiros. Holloway partiu da premissa de que os imigrantes chegados a São Paulo condiziam com os interesses da política imigratória vigente: eram pobres e sem recursos, dependentes da passagem subsidiada e colocação nas fazendas. Logo, os imigrantes que compraram terras o teriam feito acumulando capital por meio do trabalho como colonos. Analisando a Estatística Agrícola de 1905, o autor notou que, em 34 dos 97 municípios da região cafeeira e de fronteira paulistas, imigrantes eram donos de mais de $30 \%$ das propriedades recenseadas. Nessas áreas estavam 55\% do total de propriedades rurais do estado à época. ${ }^{24}$

Holloway também destaca que a grande mobilidade dos imigrantes, permitindo, ao final de um contrato de trabalho, procurar fazendas que oferecessem melhores remunerações; a imigração em famílias, com muitos membros em idade de trabalho ativa; o papel da renda não-monetária, ou seja, das roças de subsistência, tornaram viável ao imigrante, em condições ideais, acumular capital e adquirir propriedades. Ainda assim, muitos não teriam conseguido se tornar proprietários se não fosse pela expansão da fronteira agrícola e pelas crises do café. Os que conseguiram se beneficiar dos contratos de colono para acumular recursos e se tornar proprietários independentes o fizeram apenas depois de muitos anos de trabalho, poupança e baixo consumo - o mesmo que preconizavam os viajantes que visitaram o estado no período. ${ }^{25}$

Herbert Klein, da mesma forma que Holloway, não negou que os colonos sofreram exploração nas mãos dos fazendeiros e que muitas famílias italianas tiveram experiências difíceis durante seu período de trabalho nas fazendas. Apesar disso, para o autor, não haveria dúvidas quanto à capacidade do colono de acumular poupança e

\footnotetext{
${ }^{24}$ Thomas Holloway, "The coffee colono of São Paulo, Brazil: migration and mobility, 1880-1930," in Land and Labour in Latin America: Essays on the Development of Agrarian Capitalism in the nineteenth and twentieth centuries, eds. Kenneth Duncan e Ian Rutledge (Cambridge University Press, 1978), 311-3. ${ }^{25}$ Holloway, "The coffee," 318-9.
} 
adquirir terras. No início, os italianos teriam comprado pequenas propriedades em terras marginais das regiões de exploração mais antigas ou nas fronteiras agrícolas. Para Klein seria "óbvio que os italianos se tornaram proprietários de terras significativos desde o início [da imigração em massa]". ${ }^{26}$

A visão extremamente positiva de Antonio Piccarolo e Alfredo Ellis Jr., de que a maioria ou todos os colonos italianos teriam se tornado proprietários não encontra respaldo na amostra obtida pelo matching nas seções anteriores. Por outro lado, apesar do resultado do matching dos italianos proprietários com os em trânsito pela Hospedaria ter sido baixo, a amostra obtida parece confirmar o que preconizam autores otimistas como Thomas Holloway e Herbert Klein. Além disso, o sucesso relativo dos imigrantes dependia de regiões em que encontravam melhores condições para adquirir terra. Os italianos proprietários, como mostrado no capítulo anterior, estavam mais presentes na Central e Araraquarense. Na Mogiana, esses italianos superavam todas as outras nacionalidades. A amostra reflete esse cenário: a quase totalidade (96\%) dos italianos que se tornaram proprietários eram chefes de família, chegados para o trabalho nas fazendas ainda nos anos 1890 e adquiriram terras nas áreas então de fronteira ou onde o café já não dominava a agricultura.

De fato, a aquisição de terras pelos italianos não foi homogênea em toda a zona cafeeira, algo que já foi observado no capítulo anterior. Fernando Antônio Abrahão, analisando os inventários post mortem para a comarca de Campinas (região Central) entre 1870 e 1940, mostrou que produtor rural era a principal ocupação entre os inventariados, chegando a $23,2 \%$ do total. O autor destaca a presença de produtores rurais entre os italianos a partir de 1895, indicando a aquisição de terras como uma realidade para os italianos chegados em períodos anteriores à grande imigração para São Paulo. Abrahão aponta também um número crescente de proprietários rurais nos inventários do período de 1920 a 1940. O autor encontrou 48 produtores rurais entre os 173 inventários analisados no período, o que sugere que os italianos que chegaram para o trabalho nas fazendas de café do município teriam obtido terras em Campinas. ${ }^{27}$ Em 1905, existiam 88 proprietários italianos em Campinas listados na Estatística Agrícola. Destes, no matching aqui realizado foram encontrados registros na Hospedaria de Imigrantes para apenas cinco italianos (5,6\% do total). É razoável supor, visto que

\footnotetext{
${ }^{26}$ Herbert S. Klein, "A integração dos italianos no Brasil, na Argentina e Estados Unidos," Novos Estudos CEBRAP 25 (Out., 1989): 104-6.

27 Abrahão, "Padrões," 61-3.
} 
Abrahão encontrou evidências de proprietários rurais entre os inventariados mais antigos de sua amostra, que os italianos que figuravam como proprietários rurais no município também fossem aqueles que haviam chegado em levas anteriores a 1884, especialmente pelo fato de Campinas estar em uma região onde a cafeicultura já vinha perdendo importância no início do século XX.

Carlos Bacellar mostrou que mesmo na área de Ribeirão Preto, no coração da Mogiana, durante o apogeu do café no início do século XX, os sitiantes estrangeiros teriam surgido logo no final do século XIX, estabelecendo-se em terras de menor valor e somente adquirindo propriedades maiores e melhores com as sucessivas crises do café e, em especial, com a crise de $1929 .{ }^{28}$ Em 1905, 38 italianos possuíam propriedades rurais em Ribeirão Preto, $14 \%$ dos quais (5 proprietários) haviam chegado pela Hospedaria de Imigrantes, percentual este acima da média encontrada na amostra obtida para essa nacionalidade $(9,8 \%)$. Desses cinco proprietários, quatro possuíam pequenas propriedades e um uma propriedade média, todos dedicando toda a área cultivável à produção cafeeira. Diferentemente do caso de Campinas, um número possivelmente maior de italianos que chegaram por meio do programa de subsídios para o trabalho nas fazendas cafeeiras parecem ter conseguido, então, obter terras em Ribeirão Preto.

Já Oswaldo Truzzi, examinando os colonos italianos em São Carlos, chega a uma conclusão distinta da apresentada para Ribeirão Preto. Para o autor, seria enganosa a noção de que os colonos estavam, aos poucos, transformando-se em pequenos proprietários, ao menos antes de 1930. Os caminhos que levariam o imigrante de colono a proprietário seriam mais demorados, envolvendo uma ou duas gerações, e a migração para os municípios atuaria como um degrau nessa ascensão. ${ }^{29} \mathrm{O}$ aumento do preço das terras com a expansão dos cafezais nos anos 1890 e começo do 1900 tornava-se um impedimento para a aquisição de propriedades rurais pelos estrangeiros. Truzzi usou os dados do Almanach de São Carlos de 1894 para mostrar que eram raros os sobrenomes estrangeiros dentre os proprietários de terra listados no município. $\mathrm{O}$ autor também fez uso da Estatística Agrícolas de 1905 para mostrar que em 1904-5 havia apenas 61 propriedades rurais pertencentes a estrangeiros dentre as 313 listadas no município.

\footnotetext{
${ }^{28}$ Carlos de Almeida Prado Bacellar, "O apogeu do café na Alta Mojiana," in Na estrada do Anhanguera: uma visão regional da história paulista, orgs. Carlos de Almeida Prado Bacellar e Lucilia Reis Brioschi (São Paulo: Humanitas, 1999), 150.

${ }^{29}$ O Almanaque de São Carlos de 1928 retrataria esse caminho de negócios que os italianos trilhariam no anseio de conseguir se tornar proprietários de terra: "passando da roça ao pequeno commercio, do pequeno ao grande commercio,' da pequena a grande industria, e do commercio e da industria (...) a proficientes sitiantes ou abastados fazendeiros". Truzzi, "Café," 89.
} 
Além disso, a área média das propriedades dos imigrantes seria muito inferior à dos nacionais. ${ }^{30}$ De fato, no geral, as propriedades rurais dos italianos em 1905 possuíam tamanho médio de 25 alqueires, frente aos 41 dos estrangeiros como um todo e 56 alqueires dos nacionais. No entanto, dos 40 italianos com propriedade rural no município de São Carlos, quatro - ou $10 \%$ do total - foram encontrados na amostra obtida do matching da Estatística Agrícola com a Hospedaria, percentual dentro da média $(9,8 \%)$ encontrada na amostra. Dessa forma, parece razoável supor que os italianos em São Carlos não estavam tão distantes da aquisição de um pedaço de terra, seguindo a tendência dos conterrâneos no restante do estado.

Truzzi afirma também que as grandes propriedades em São Carlos sobreviveram mesmo quando a produção cafeeira na região declinou e a despeito dos efeitos das crises do café e de 1929. ${ }^{31}$ É possível, porém, que, não vendo oportunidade de aquisição de terras na região, parte dos colonos localizados inicialmente em São Carlos tenham seguido em direção à fronteira agrícola do estado de São Paulo ou para outras zonas aonde fosse mais fácil comprar terras, um fenômeno recorrente que foi identificado no exercício do matching realizado, conforme notado antes.

Nas regiões de Ribeirão Preto e São Carlos, os salários vinham caindo drasticamente no começo do século XX em comparação com a segunda metade dos anos 1890. Em Ribeirão Preto os salários nominais que oscilavam entre $70 \$ 000$ e $90 \$ 000$ réis pelo trato de 1.000 pés de café e $\$ 500$ pela colheita de um alqueire nos anos 1890, declinaram para $50 \$ 000$ a $70 \$ 000$ pelo trato e a $\$ 300$ pela colheita em 1903 . Em São Carlos, os valores passaram de $100 \$ 000$ pelo trato para $60 \$ 000$ e $\$ 400$ pela colheita. ${ }^{32} \mathrm{Na}$ amostra obtida pelo matching, os italianos proprietários chegaram ao estado de São Paulo justamente nos anos 1890 e se dirigiram para as fazendas de café dessas regiões. Esses salários melhores podem ter ajudado os colonos a formarem poupança e tornado a aquisição de terra mais factível nas regiões cafeeiras, antes da queda das remunerações nos anos seguintes. De fato, na amostra, 58\% das pequenas, $75 \%$ das médias e $80 \%$ das grandes propriedades dos italianos estavam localizadas nas regiões cafeeiras da Mogiana e Paulista, bem como na região da Araraquarense. Os italianos proprietários identificados na amostra seguiram a tendência geral dos italianos

\footnotetext{
30 Truzzi, "Café," 87-93.

31 Oswaldo Truzzi, "Percursos e descaminhos da italianidade no interior paulista," in Anais do $37^{\circ}$ Encontro Anual da ANPOCS (Águas de Lindóia, set. 2013), 10.

32 Pio di Savoia, "Lo stato," 198; 202.
} 
proprietários do estado como o principal grupo de estrangeiros a obter terras na região da Mogiana. Por outro lado, os espanhóis e alemães não tiveram o mesmo destino, como será visto nas próximas subseções.

\subsubsection{Os Espanhóis}

De 1884 a 1904 foram registrados 87.505 espanhóis na Hospedaria de Imigrantes em São Paulo, o equivalente a $12,3 \%$ do total de imigrantes registrados na Hospedaria no período. O levantamento das propriedades rurais do estado em 1905 revelou a existência de 411 propriedades pertencentes a esta nacionalidade. Com o procedimento de matching realizado, obteve-se uma amostra com 132 proprietários de terra espanhóis com passagem pela Hospedaria, 32,6\% do total de proprietários espanhóis, o maior percentual entre todas as nacionalidades analisadas.

Os resultados encontrados diferem do que é afirmado por parte da literatura. Para José de Souza Martins, os espanhóis que se aventuraram nas fazendas paulistas tinham um perfil diferentes daquele de outras nacionalidades europeias que foram para São Paulo. Segundo o autor, em sua grande maioria camponeses pobres sem-terra, chegados tardiamente durante a crise da economia cafeeira, esses espanhóis não teriam se engajado em contratos tão vantajosos quanto os assinados pelos italianos anos antes. ${ }^{33}$ Souza Martins usa a Estatística Agrícola de 1905 para dar apoio a essa interpretação, afirmando que havia apenas 415 espanhóis listados como proprietários de terra no estado de São Paulo.

Vanessa Dias, estudando a mobilidade social dos espanhóis no município de Franca com inventários post-mortem, chegou a resultado similar ao afirmar que as possibilidades que o trabalho na fazenda cafeeira oferecia para a formação de pecúlio eram poucas para que fosse possível aos espanhóis tornarem-se proprietários. Segundo a autora, a grande maioria dos que haviam adquirido terras em Franca possuíam propriedades com menos de 10 alqueires e nenhum imigrante possuía terras com mais de 50 alqueires. Muitos teriam comprado propriedades em conjunto, dividindo-as com parentes ou amigos. A autora sugere também que essas propriedades podem ter sido adquiridas como forma de pagamento por serviços prestados a fazendeiros ou compradas a preços baixos por terem se desvalorizado no mercado em um período de

\footnotetext{
${ }^{33}$ Martins, “A imigração,” 11.
} 
crise na cafeicultura. ${ }^{34}$ De fato, Franca não parece, ao menos logo no início do século $\mathrm{XX}$, ter sido um ambiente propício para os estrangeiros adquirirem terras. Das 384 propriedades em Franca listadas na Estatística Agrícola, apenas 14 pertenciam a estrangeiros e nenhuma a espanhóis.

Herbert Klein elaborou uma interpretação oposta à de José Souza Martins e Vanessa Dias. Ainda que, de fato, as condições encontradas pelos espanhóis na chegada possam ter sido piores, segundo o autor um número significativo de colonos conseguiu poupar e comprar terras, apesar dos percalços e das explorações sofridas nas fazendas de café. ${ }^{35}$ Deve ser levado em conta, como mostrado no Capítulo 3, que na época da Estatística Agrícola, em 1904-05, a imigração espanhola estava apenas começando a aumentar em São Paulo. Foi apenas com a proibição por parte do governo italiano da imigração subsidiada para São Paulo, em 1903, que os espanhóis passaram a compor um grupo significativo de imigrantes e alcançaram a liderança nas entradas no estado até 1920. No Censo Demográfico de 1920, os espanhóis aparecem em terceiro lugar entre os estrangeiros proprietários de terra, com 3.530 propriedades. ${ }^{36}$ Enquanto os italianos e portugueses aumentaram suas propriedades em 2,5 vezes entre 1905 e 1920, os espanhóis deram um salto de oito vezes e meia no mesmo período. ${ }^{37}$

Uma possível hipótese que explicaria os resultados obtidos na amostra, de que $32,6 \%$ dos espanhóis que se tornaram donos de terra teriam passado pela Hospedaria, é que as condições - econômicas e sociais - na Espanha no começo do século XX eram mais adversas que nos outros países europeus, como a Itália. ${ }^{38} \mathrm{O}$ retorno à pátria não

\footnotetext{
34 Vanessa Dias, "Inserção às avessas: a imigração espanhola em Franca-SP (19001955)" (Dissertação de Mestrado, UNESP, 2010).

${ }^{35}$ Klein, A imigração, 65-6.

${ }^{36}$ Brasil, Recenseamento 1920, v. III, 1a parte.

${ }^{37}$ É importante observar que é possível que, em 1920, uma parcela dos proprietários rurais listados como nacionais fossem, na verdade, filhos da primeira geração de italianos chegados ao estado de São Paulo no início da imigração em massa, o que não acontece com os espanhóis, visto serem de uma imigração mais tardia.

${ }^{38}$ Cristobal Botella, contemporâneo do movimento imigratório espanhol, escreveu em 1888 que as causas da imigração espanhola residiam não no aumento populacional ou no "espírito aventureiro" da população, mas sim na miséria, na falta de trabalho e de subsistência. Cristóbal Botella, El problema de la emigración (Madrid: Tipografia de los huérfanos, 1888): 160-1. Blanca Sanchez-Allonso, estudando os determinantes da imigração espanhola, também ressalta a questão da pobreza e afirma que o aumento da renda per capita na Espanha estava positivamente relacionada com a emigração, já que permitia aos espanhóis financiarem suas passagens para o Novo Mundo. Blanca Sánchez-Alonso, "Those Who Left and Those Who Stayed behind: Explaining Emigration from the Regions of Spain, 1880-1914," The Journal of Economic History 60, n. 3 (Sep. 2000). Para Herbert Klein, os espanhóis chegados ao Brasil com passagens subsidiadas seriam mais pobres que os que emigravam para outras partes do Novo Mundo, além de emigrarem com famílias, diminuindo as possibilidades de retorno à pátria. Klein, A imigração, 32. Ver, também: Cánovas, “A emigração,” 40-3; 199-204.
} 
parecia ser uma possibilidade para a maioria desses espanhóis, o que levaria os imigrantes a investirem os recursos ganhos nas fazendas durante sua permanência em São Paulo ou na re-emigração para outros países. As estatísticas de entrada e saída de imigrantes pelo porto de Santos mostram que, entre 1894 e 1901, dos quase 70.000 espanhóis entrados, apenas 14.100 deixaram o estado, o que representa um coeficiente geral de fixação de $80 \% .{ }^{39}$ Em comparação, no mesmo período, o coeficiente de fixação para os italianos foi de apenas $56 \%$, e dos portugueses, $47 \% .{ }^{40}$ Posteriormente, entre 1905 e 1927, o coeficiente de fixação para os espanhóis foi de 55,5\%, ou seja, mais da metade dos espanhóis que chegou permaneceru no estado no período. Esse coeficiente continuou bastante superior ao dos italianos $(15,6 \%)$ e portugueses $(46,1 \%) .{ }^{41}$ Ainda que não haja estatísticas de saídas descriminadas por nacionalidade destino para o período (1886 a 1905) abordado por este capítulo, para anos posteriores os dados mostram que de 1911 e 1919, dos 121.990 espanhóis entraram no estado de São Paulo pelo porto de Santos, 22.457 deixaram o estado em direção à Argentina e ao Uruguai e 20.310 em direção à Europa. ${ }^{42}$

Marília Dalva Cánovas deu outra contribuição importante sobre a trajetória dos imigrantes espanhóis. A partir de relatos colhidos de imigrantes espanhóis e seus descendentes estabelecidos na região de Villa Novaes entre 1880 e 1930, então pertencente ao município de Jaboticabal, de registros civis e de compra e venda de terras, e do cruzamento de informações com os registros de matrícula da Hospedaria de Imigrantes, Cánovas reconstituiu a trajetória e permanência desse grupo de estrangeiros na região. ${ }^{43}$

Divergindo do que afirma José de Souza Martins, mas apresentando um argumento diferente do exposto por Herbert Klein, Cánovas aponta que, ao menos no caso de Villa Novaes, os espanhóis dirigidos às fazendas paulistas não eram necessariamente representantes das classes sociais mais baixas, sem posses ou condições financeiras; muitos possuíam algum pecúlio e até mesmo propriedades rurais

\footnotetext{
${ }^{39} \mathrm{O}$ coeficiente geral de fixação é calculado pela razão entre o saldo migratório de cada nacionalidade pela quantidade de entrados dessa nacionalidade em um determinado período em questão.

${ }^{40}$ São Paulo, Relatório... Antonio Candido Rodrigues 1901, 120-1.

${ }^{41}$ São Paulo, Relatório da Agricultura apresentado ao Dr. Julio Prestes de Albuquerque, Presidente do Estado, pelo Dr. Fernando Costa, Secretário da Agricultura (São Paulo, s/d, s/e.), 177.

${ }^{42}$ São Paulo, Relatórios da Agricultura... 1911-1920. Em outro trabalho, eu mostrei que entre 1896 e 1904 cerca de 20\% das saídas de imigrantes do porto de Santos eram em direção ao Rio da Prata. Lanza, "Imigração," 143.

${ }^{43}$ Cánovas, "A emigração," 153-5.
} 
em suas localidades natais. Cánovas sustenta, a partir de relatos desses imigrantes, que o trabalho nas fazendas e a possibilidade de produção de alimentos permitiam, após algum tempo (entre 2 e 6 anos), a compra de pequenas propriedades pela família ou em conjunto com outras famílias. ${ }^{44}$ A autora também observa que era comum o deslocamento em busca de terras mais baratas em outras regiões. ${ }^{45}$

Fernando Antônio Abrahão também afirma que os espanhóis estabelecidos em Campinas não eram tão pobres quanto o apresentado pela historiografia. O autor relata espanhóis no município atuando em diversas atividades urbanas, como industriais, artesãos, profissionais liberais, além de figurarem também como proprietários rurais. ${ }^{46}$

João Paulo da Silva, estudando a inserção e assimilação de espanhóis no interior do estado de São Paulo, segue a mesma linha de Cánovas e Abrahão e sustenta que os espanhóis chegados a Sorocaba para o trabalho nas fazendas eram de origem rural e possuíam pequenas propriedades em suas regiões natais. $\mathrm{O}$ autor também cita a situação econômica da Espanha no final do século XIX e começo do XX como motivadora para que esses espanhóis deixassem suas propriedades e emigrassem para o interior de São Paulo. $^{47}$

A amostra obtida por matching para o caso dos espanhóis condiz com o que foi apresentado no Capítulo 3 sobre a localização das propriedades desses imigrantes espanhóis e confirma também o que foi exposto por Klein, Cánovas, Abrahão e Silva. Dos 131 imigrantes espanhóis mapeados com propriedade de terra no estado de São Paulo em 1905, 38 deles possuíam terras na Araraquarense e 17 na Alta Sorocabana, zonas de fronteira agrícola do estado naquele momento. Os espanhóis tendiam a se estabelecer nessas zonas, onde a terra era mais barata e ainda estavam sendo abertas à ocupação por pequenos proprietários. A amostra indica também esse grupo se estabelecendo em regiões onde o café vinha perdendo importância, como a Central (com 28 proprietários) - como ocorreu no município de Campinas, estudado por Abrahão e que teve, dentre os 641 proprietários rurais, 14 de origem espanhola, dos quais quatro foram localizados nos registros da Hospedaria. Outro exemplo ocorreu na zona cafeeira da Paulista (19 proprietários). Diferentemente do caso italiano, apenas três propriedades de espanhóis foram encontradas na amostra na região da Mogiana. Em

\footnotetext{
${ }^{44}$ Cánovas, "A emigração," 202, notas 387-8; 226-8; 264-5; 268-9.

${ }^{45}$ Cánovas, "A imigração," 234 e ss.

${ }^{46}$ Abrahão, "Padrões," 71-2.

${ }^{47}$ Silva, "Espanhóis," 118-21.
} 
1905, na Mogiana o preço médio do alqueire de terra (140\$) era 30\% mais elevado do que na Alta Sorocabana (105\$) e Central (102\$), 10\% mais alto que na Araraquarense (125\$) e $240 \%$ maior do que que na Noroeste (58\$), indicando que, para os espanhóis, talvez o valor da terra na principal zona cafeeira do estado fosse proibitivo.

Dos estabelecimentos rurais pertencentes aos espanhóis identificados no matching, $81 \%$ eram pequenas propriedades, com menos de 25 alqueires. Apenas 24 propriedades possuíam tamanho médio, sendo que Araraquarense, Paulista e Alta Sorocabana reuniam 16 delas. Havia apenas 3 propriedades grandes, duas localizadas na zona de Sorocaba e uma na Central, e nenhum latifúndio entre os espanhóis proprietários mapeados. A tabela 4.3 abaixo apresenta esses dados. Na amostra obtida, as propriedades dos espanhóis possuíam, em média, 17,7 alqueires, frente aos 23 alqueires dos italianos, 45 dos austríacos e 47 dos alemães. Assim como para o caso dos italianos, $81 \%$ dos estabelecimentos rurais dos espanhóis eram pequenas propriedades. Por outro lado, $19 \%$ das propriedades eram médias (frente a $16 \%$ dos italianos) e $2,3 \%$ eram grandes propriedades (frente a $3,6 \%$ para os italianos).

Tabela 4.3 - Tamanho e localização das propriedades mapeadas dos espanhóis no estado de São Paulo, por região, 1905

\begin{tabular}{ccccc}
\hline & Pequenas & Médias & Grandes & Latifúndios \\
\hline Capital & 6 & & & \\
Vale do Paraíba e Litoral Norte & 9 & 1 & 2 & \\
Sorocaba & 1 & 2 & 1 & \\
Central & 25 & 1 & \\
Mogiana & 2 & 5 & \\
Paulista & 14 & 7 & & \\
Araraquarense & 31 & 1 & \\
Noroeste & 1 & & \\
Alta Sorocabana & 12 & 1 & \\
Baixa Sorocabana & & & \\
Santos e Litoral Sul & 2 & & \\
\hline
\end{tabular}

Fonte: São Paulo, Estatística Agrícola de 1905; Registro de Matrícula da Hospedaria de Imigrantes, Memoria do Imigrante, Arquivo Público do Estado de São Paulo.

Apesar da entrada de espanhóis no estado de São Paulo ter sido uma imigração tardia, a amostra aqui obtida corrobora a interpretação de Marília Cánovas e Herbert Klein sobre o acesso à terra por esses imigrantes. Apesar de que os primeiros espanhóis possam não ter encontrado contratos tão vantajosos nas fazendas, como o retorno à 
pátria não parecia ser uma opção, restava a alternativa de comprar propriedades rurais menores, localizadas em regiões mais distantes dos centros cafeeiros onde a terra era mais acessível e barata. O fato do procedimento realizado ter retornado $33 \%$ de correspondência entre os espanhóis listados como donos de terra na Estatística Agrícola e os registrados na Hospedaria é mais um indício de que os imigrantes mais pobres, vindos para o trabalho nas fazendas, conseguiram comprar terras no estado de São Paulo.

\subsubsection{Os Alemães}

A imigração alemã para São Paulo remonta aos primórdios das experiências de colonização e de emprego da mão de obra livre nas fazendas paulistas. No período da grande imigração para São Paulo, os alemães perderam importância frente aos italianos, portugueses e espanhóis. Entre 1884 e 1904 passaram pela Hospedaria apenas 9.283 imigrantes germânicos, correspondendo a $1,3 \%$ do total dos imigrantes. Os resultados obtidos do mapeamento dos proprietários de origem alemã surpreenderam, porém. A Estatística Agrícola de 1905 apontou a existência de 665 alemães como proprietários de terra no estado de São Paulo naquele ano. No entanto, apenas 21 - ou seja, 3,3\% - dos imigrantes alemães da Hospedaria aparecem listados como proprietários de terra naquele ano, o que pode significar que os alemães chegados ao estado entre 1884 e 1904 não tenham obtido condições para adquirir terras ou que tenham se dedicado a outras atividades após deixarem as fazendas de café. Esse resultado condiz com o levantado por Warren Dean em seu estudo sobre Rio Claro. O autor afirma, ao analisar as propriedades rurais no município em 1905, que os proprietários alemães listados não seriam imigrantes de primeira geração, vindos com a imigração em massa, mas sim imigrantes mais antigos; e que, na verdade, os estrangeiros de origem germânica não se dedicavam mais à agricultura. ${ }^{48}$

Diante do baixo número obtido tanto pelo procedimento de matching quanto por Warren Dean, vale examinar com mais detalhe e outras informações as características dos proprietários alemães em São Paulo. ${ }^{49}$ Conforme observado em outro capítulo, as primeiras experiências bem documentadas de trabalhadores germânicos nas fazendas

\footnotetext{
${ }^{48}$ Dean, Rio Claro.

49 Os resultados detalhados da análise e dos dados citados a seguir serão publicados na forma de um capítulo intitulado "E 'fizeram América'? Mobilidade socioeconômica dos primeiros colonos de Ibicaba. In: Ibicaba, 200 anos: em comemoração ao colóquio do bicenentenário, organizadores Leonardo Antonio Santin Gardenal e Bruno Gabriel Witzel De Souza (Cordeirópolis: Prefeitura Municipal, 2021).
} 
paulistas datam da década de 1840, com as iniciativas do senador Nicolau Vergueiro. A firma do senador e filhos - a Vergueiro \& Cia. - contratou 423 imigrantes alemães sob o sistema de parceria em um novo experimento, a Colônia Senador Vergueiro, localizada na fazenda Ibicaba, então em Limeira.. ${ }^{50}$ A partir deste momento, a fazenda Ibicaba tornou-se um modelo na província de São Paulo e a colônia chegou a abrigar 900 estrangeiros. Na década de 1850, a província recebeu pouco mais de 6.700 imigrantes, dentre os quais imigrantes de língua alemã, havendo um crescimento substancial das colônias particulares nos moldes da experiência de Vergueiro. ${ }^{51}$ Em fins da década de 1850, porém, as queixas frequentes dos colonos acerca dos maus tratos e dívidas acumuladas levaram a revoltas e protestos em diversas colônias. O episódio mais famoso foi a Revolta dos Colonos, ou dos Parceiros, ocorrida em Ibicaba em 185657, que marcou o início do declínio do sistema de parceria. ${ }^{52} \mathrm{~A}$ documentação existente desse primeiro experimento realizado por Vergueiro nos permitiu localizar não apenas ex-colonos como proprietários na Estatística Agrícola de 1905 como também seus possíveis descendentes.

A identificação de imigrantes em diferentes fontes foi possível graças às listas de registros existentes na Fazenda Ibicaba, arrolando os imigrantes engajados como colonos na colônia Senador Vergueiro. Essas listas incluem uma de abertura da colônia, de 1846, contendo os 84 chefes de família alemães; um levantamento das contas de 72 colonos feito pelo vice-cônsul Suíço, Charles Perret-Gentil, como parte de uma obra de propaganda em favor da colonização pelo sistema de parceria; e uma lista com os nomes de 99 colonos saídos da fazenda Ibicaba até 1857, elaborada pelos proprietários da Vergueiro \& Cia, muito possivelmente com o objetivo de divulgar a prosperidade alcançada por aquelas famílias. ${ }^{53}$

Combinando essas três listas e excluindo os nomes que se repetiam, obteve-se uma lista única com 128 nomes e sobrenomes germânicos de colonos da Ibicaba.

\footnotetext{
${ }^{50}$ Forjaz, O Senador; Stolcke e Hall, "Introdução"; Costa, Da monarquia, cap. 5; Lamounier, "Between," 156-61.

${ }^{51}$ Vergueiro \& Cia foi responsável por introduzir uma boa parte desses imigrantes. Sobre os contratos de imigração, ver Gonçalves (2010). As estatísticas disponíveis de entrada de imigrantes em São Paulo na década de 1850 apenas trazem números em separado para os portugueses (2.571) e espanhóis (37). O restante figura sob a sigla "Diversos" (3.666) no quais, certamente, estavam os alemães que se dirigiram para as colônias da província. São Paulo, Relatório da Agricultura... 1900.

52 Sobre a revolta de Ibicaba, ver as memórias de seu líder, o mestre-escola suíço Thomas Davatz (1941).

${ }^{53}$ Essas listas encontram-se reproduzidas em: José Eduardo Heflinger Jr., A revolta dos parceiros na Ibicaba (Limeira: Unigráfica, 2009), 25, 29-30, 62.
} 
Desses nomes, foram localizados nove proprietários na Estatística Agrícola de $1905 .^{54}$ Embora seja possível que algumas dessas pessoas sejam descendentes dos pioneiros, que compartilhavam o nome e sobrenome de seus antepassados, é também razoável que alguns deles fossem pessoas mais idosas, que haviam passado sua infância (e talvez adolescência) em Ibicaba e ainda estavam vivas em 1905.

Todos os nove ex-colonos que aparecem na Estatística Agrícola de 1905 adquiriram propriedades em Limeira ou em municípios próximos à antiga colônia, como por exemplo São Carlos, Rio Claro e Campinas. Um dos ex-colonos possuía três propriedades, elevando o total da amostra a onze propriedades. Com exceção de dois proprietários, para os quais não foram encontrados dados, os outros sete se dedicavam à produção de gêneros alimentícios, como milho, feijão e arroz, enquanto cinco plantavam café. Em relação ao tamanho dessas propriedades, não havia latifundiários entre os antigos colonos da Ibicaba. Das onze propriedades, quatro tinham menos de 25 alqueires, seis tinham entre 28 e 50 alqueires e apenas uma propriedade pode ser considerada grande, com 200 alqueires. ${ }^{55} \mathrm{O}$ tamanho médio das propriedades desses excolonos era de 40 alqueires, superior tanto às propriedades dos italianos (que era de 23 alqueires) quanto dos espanhóis (17,7 alqueires) listadas no mapeamento apresentado anteriormente.

Além dos nove proprietários mencionados, a busca pelos sobrenomes dos 128 ex-colonos na Estatística Agrícola de 1905 retornou ainda 66 possíveis parentes com propriedades. Os municípios próximos à Ibicaba concentraram boa parte desses estabelecimentos. Em Rio Claro estavam treze deles, seguido por Limeira (8), Pirassununga (7), Campinas (4) e São Carlos (2). O restante das propriedades (32) estava espalhado por todo estado, em municípios de zonas de fronteira agrícola como Bauru, na região Noroeste, até regiões já antigas como a Capital. Em termos de tamanho, 25 unidades eram pequenas propriedades, 19 médias, 20 grandes e 3 formavam latifúndios. Dentre esses latifúndios, encontravam-se as unidades de grandes cafeicultores, como Francisco Schmidt, que sozinho possuía oito propriedades com 2.500 alqueires de terra e 1,6 milhão de pés de café. Havia também pequenos sitiantes, dedicados exclusivamente ao cultivo de alimentos. As listas mencionadas - de contas

\footnotetext{
${ }^{54}$ São eles Jacob Seckler, João Fahl, José Schaefer, Guilherme Hummel, Luiz Sass, Jacob Sass, Jacob Lahr, Jacob Scholl e Felippe Rigo. Todos os nomes foram abrasileirados no registro da Estatística Agrícola de 1905.

55 Os nove ex-colonos que aparecem como donos de terra em 1905 possuíam um total de onze propriedades rurais. Um dos ex-colonos, Luiz Sass, possuía três propriedades em Limeira.
} 
dos parceiros e de saída da colônia - indicam também que um saldo positivo durante a estada na fazenda (de 1847 a 1850 e/ou de 1850 a 1857), ou uma poupança acumulada ao sair propriedade (em 1857), parece ter sido um fator importante na capacidade das famílias em tornarem-se proprietárias de terra, uma vez que foi possível identificar os próprios colonos e seus possíveis descendentes entre os proprietários em 1905.

Dos 665 alemães proprietários rurais listados na Estatística Agrícola de 1905, a correspondência com os registros da Hospedaria de Imigrantes de São Paulo retornou apenas 21 nomes. A busca na Estatística Agrícola utilizando os nomes e sobrenomes de 128 ex-colonos da Ibicaba retornou nove ex-colonos e 66 possíveis parentes como donos de terra em 1905. Warren Dean, ao que tudo indica, tinha razão. No exposto até aqui, os alemães que se tornaram proprietários rurais até 1905 não foram os que passaram pela Hospedaria no período da imigração em massa. A última nacionalidade analisada no matching, os austríacos, teve destino e trajetória similares aos alemães.

\subsubsection{Os Austríacos}

À época da imigração em massa, o que se considerava como "austríaco" difere do elemento austríaco conhecido atualmente. Até 1918 o Império Austro-Húngaro englobava limites territoriais muito além dos que hoje definem a Áustria e a Hungria. Poloneses, húngaros, romenos, eslovenos, croatas, italianos, tchecos, eslovacos, alemães de territórios austríacos, da Romênia e da Hungria eram incluídos no chamado "imigrante austríaco". Essa multietnicidade levou a problemas nos registros das estatísticas de imigração. $\mathrm{Na}$ ausência do controle dos emigrantes na origem, as estatísticas emigratórias ficavam a cargo dos portos de saída, o que gerou um grande número desses imigrantes classificados conforme os critérios de cada porto ou de acordo com a autodefinição do próprio imigrante. ${ }^{56}$ Uma etnia dentre esses imigrantes austríacos que se transferiram para São Paulo formava maioria: os tiroleses. ${ }^{57}$

Essa etnia dos austríacos tem sua origem na região de Trento-Tirol, hoje província autônoma italiana que pertenceu ao Império Austro-Húngaro até 1918. Apesar dos trentinos - ou tiroleses - poderem ter sido registrados como italianos na Hospedaria de Imigrantes, grande parte dos imigrantes classificados como austríacos em trânsito

\footnotetext{
${ }^{56}$ Ursula Prutsch, A emigração de austríacos para o Brasil (1876-1938) (Brasília: Embaixada Austríaca no Brasil, 2011), 3-7.

${ }^{57}$ Renzo Grosselli, Da schiavi Bianchi a coloni. Un progetto per la fazenda - Contadini trentini (veneti e Lombardi) nelle foreste brasiliane. Parte IV - São Paulo 1875-1914 (Trento: Provincia Autonoma di Trento, 1991), 154.
} 
pela Hospedaria de Imigrantes tinham, de fato, sobrenomes muito mais similares aos de origem italiana que germânica. ${ }^{58}$ Entre 1884 e 1904, passaram pela Hospedaria pouco mais de 18.000 austríacos, o equivalente a 2,6\% do total de imigrantes registrados na Hospedaria. Na Estatística Agrícola de 1905 constavam 89 proprietários de terras austríacos; 59 dos quais possuíam sobrenomes de origem italiana, que Renzo Grosselli considera "sobrenomes tipicamente trentinos". ${ }^{59} \mathrm{O}$ procedimento de correspondência realizado retornou uma amostra com 24 proprietários identificados pelo cruzamento das fontes. Destes, 18 possuíam sobrenomes de origem italiana.

Em São Paulo, os austríacos, assim como os alemães, localizaram-se principalmente nas zonas Central (16\%) e Paulista (34,5\%), em especial nos municípios de Campinas, Pirassununga, Itu, Descalvado, Piracicaba, Araras e São Carlos. A Mogiana (23\%) aparece em seguida, com Ribeirão Preto $(27,7 \%)$ como o principal destino desses imigrantes na região. ${ }^{60}$ Nessas mesmas zonas encontram-se as propriedades localizadas na amostra dos austríacos. De fato, há informação do destino após a saída da Hospedaria de 11 dos 24 proprietários identificados. Seis deles originalmente instalaram-se como colonos em Ribeirão Preto. Ainda que nenhum deles tenha adquirido terras no município, suas propriedades continuaram na Mogiana, nos municípios de Pitangueiras e Amparo.

A área média das propriedades dos austríacos na amostra é de 40 alqueires, bem superior à registrada dos italianos (23) e espanhóis $(17,7)$ e equivalente à dos alemães. Dos 24 proprietários mapeados, 17 possuíam pequenas propriedades. Na Mogiana estavam seis delas, seguida pela Paulista, com três propriedades, e Araraquarense e Central, com duas cada. Cinco propriedades eram médias, localizadas na Paulista (2), Central (2) e Araraquarense (1). A correspondência entre as fontes retornou, também, dois grandes proprietários austríacos. O maior era Antônio Furlan (grafado nas estatísticas como Turlan), que possuía uma propriedade em Piracicaba com 310 alqueires, dos quais apenas 10 alqueires estavam em cultivo, com 14.000 pés de café, além de arroz e milho. Em seguida vinha a propriedade de Luigi Negri e irmãos, também em Piracicaba, com uma propriedade de 295 alqueires, com a maior produção

\footnotetext{
${ }^{58}$ Grosselli, Da schiavi, 166

${ }^{59}$ São Paulo, Estatística Agrícola. O autor afirma também que pelo menos 70 trentinos foram inclusos nas estatísticas como sendo italianos. Além disso, Grosselli ressalta que deveriam ser incorporados os trentinos proprietários de terra de Itu que não constavam na Estatística Agrícola de 1905. Como visto no capítulo 3, alguns municípios não tiveram os resultados do levantamento estatístico publicados em separado. Grosselli, Da schiavi, 367.

${ }^{60}$ Registros de Matrícula, Hospedaria de Imigrantes, 1882-1920.
} 
cafeeira da amostra: 40.000 pés cultivados em 20 alqueires. Negri havia entrado na Hospedaria em 1884 e se instalado em São Bernardo, dirigindo-se em algum momento para o interior de São Paulo.

Assim como os alemães, a imigração austríaca para o Brasil tem origem anterior aos anos da imigração em massa. A crise econômica vivida pelo Império AustroHúngaro na segunda metade do século XIX, os embargos econômicos impostos pela Itália aos produtos da região, o empobrecimento generalizado do grande número de camponeses que compunham a população tirolesa, e a obrigação do serviço militar contribuíram para que os habitantes do Império buscassem refúgio no Brasil e em outros países. ${ }^{61}$ Os primeiros austríacos chegaram ao Brasil em 1859, dirigindo-se para as colônias no Espírito Santo. Nos anos seguintes, as províncias do sul do país foram o destino principal desses estrangeiros. Em São Paulo, em 1877, os primeiros austríacostrentinos foram para o trabalho na fazenda Sete Quedas, de Joaquim Bonifácio do Amaral, Visconde de Indaiatuba, localizada em Campinas. ${ }^{62}$ Renzo Grosselli reconstituiu a trajetória de algumas primeiras famílias trentinas chegadas à essa colônia e às colônias de Saltinho e Salto Grande, em Campinas e Amparo, respectivamente. Assim como no caso dos alemães contratados para o trabalho na Ibicaba, foi possível encontrar informações para alguns desses colonos e seus descendentes na Estatística Agrícola de 1905.

Entre 1877 e 1883, as famílias Vitti, Forti, Correr, Brunelli, Stenico, Degasperi e Cristofoletti foram contratadas pelo Visconde de Indaiatuba para a colônia Saltinho, sob o sistema de parceria, pelo prazo de 9 anos, recebendo $500 \$ 000$ por alqueire de café colhido, sem extras pelo trato dos cafezais, e com direito ao uso das terras para plantio de cereais. ${ }^{63}$ Findos os 9 anos do contrato, as famílias Vitti e Forti permaneceram na fazenda do Visconde até 1887, quando se mudaram para Rio Claro. ${ }^{64}$

\footnotetext{
${ }^{61}$ Everton Altmayer Leopoldino, "O dialeto tretino da Colônia Tirolesa de Piracicaba: aspectos fonéticos e lexicais" (Tese de doutorado, FFLCH/USP, 2014), 78-81.

${ }^{62}$ Para uma história detalhada do início da imigração austríaca ao Brasil e para São Paulo, ver Leopoldo, 90-116. O Visconde de Indaiatuba, após a proibição pelo governo alemão da imigração para o Brasil, recorreu aos trentinos como substitutos, classificando-os como imigrantes de grande moralidade, união e apegados ao trabalho. Chegando em grandes famílias, não demorariam em se emancipar e quitar os débitos contraídos na contratação. Além disso, segundo o fazendeiro, seriam elementos certos para contribuir à civilização do país. Cf. José Bonifácio do Amaral, Visconde de Indaiatuba, "Introdução ao trabalho livre em Campinas," in Monografia histórica do município de Campinas, orgs. Carlos Francisco de Pádua (Rio de Janeiro: Serviço Gráfico do IBGE, 1952), 245.

${ }^{63}$ É importante notar que diversas famílias com o mesmo sobrenome, provavelmente parentes, instalaram-se nas colônias do Visconde de Indaiatuba. Grosselli apresenta uma relação com todos os imigrantes trentinos que entraram nas colônias de Saltinho e Santo Grande entre 1877 e 1883 e nela é
} 
Em 1893, os Vitti e os Forti compraram juntos a Fazenda Santanna, em Piracicaba, com 300 alqueires de extensão, por 100:000\$000, dos quais 5:000\$000 foram pagos à vista e o restante, acrescido de juros de $9 \%$ ao ano, devendo ser pago em 1901 com os frutos da colheita do café. Os Vitti compraram sua parte com o dinheiro acumulado no trabalho como colonos na fazenda do Visconde de Indaiatuba e com empréstimos contraídos junto a familiares estabelecidos na cidade de Rio Claro. Os Forti, por sua vez, recorreram a Cícero Bastos para obter o capital necessário para quitar sua parte. ${ }^{65}$

As famílias Correr, Brunelli, Stenico, Degasperi, Cristofoletti e outros membros da família Forti partiram juntas da colônia de Sete Quedas para trabalharem como colonos na fazenda Monte Alegre, em Piracicaba, de propriedade de Joaquim Rodrigues do Amaral, onde permaneceram por mais cinco anos. Também em 1893, esse grupo firmou contrato com João Batista Ponto e Firmino Bueno de Oliveira para a compra da fazenda Santa Olímpia, fundando uma colônia trentina no município de Piracicaba. ${ }^{66} \mathrm{O}$ pagamento pela fazenda contou com a obtenção de empréstimos também juntamente a Cícero Bastos, com altos juros e mediante a hipoteca da fazenda e das colheitas futuras de café. ${ }^{67}$ É possível notar que existia uma verdadeira rede de ajuda mútua entre esses imigrantes trentinos para a aquisição e quitação de terras no estado de São Paulo, seja pela aquisição em conjunto de propriedades, seja pela contratação de empréstimos com os mesmos financiadores ou com conterrâneos.

A Estatística Agrícola de 1905 traz também as propriedades descritas acima, além de austríacos e italianos trentinos proprietários oriundos das colônias do Visconde de Indaiatuba. A propriedade comprada pelos Vitti e Forti em 1893 em Piracicaba aparece listada sob o nome de Angelo Vitti e Cia, com 211 alqueires, 89 a menos do que na época da compra e com metade de sua área cultivada coberta por 30.000 cafeeiros. Além disso, Vitti aparece listado como sendo italiano, e não austríaco. A fazenda comprada em conjunto pelos Correr, Brunelli, Stenico, Degasperi, Cristofoletti e Forti aparece na Estatística Agrícola de 1905 como pertencente a "José Fortes e Cia",

possível verificar diversos imigrantes com o mesmo sobrenome, inclusive chegados em épocas diferentes. Grosselli, Da schiavi, 382-5.

${ }^{64}$ Leopoldino, "O dialeto," 111-3.

${ }^{65}$ Grosselli, Da schiavi, 375.

${ }^{66}$ Ver: Leopoldino, “O dialeto,” 110-20; Grosselli, Da schiavi, 376.

${ }^{67}$ Grosselli, Da schiavi, 376-7. 
austríaco. A propriedade tinha 150 alqueires, dos quais 28,5 alqueires estavam em cultivo com 12.000 pés de café, além de milho, arroz e feijão.

Renzo Grosselli apresenta quatro listas de trentinos estabelecidos em 1877 e 1883 como colonos nas fazendas de Saltinho e Salto Grande. Essas listas, combinadas, possuem 84 sobrenomes únicos. Foi possível localizar propriedades de 26 possíveis parentes desses colonos e cinco propriedades dos antigos colonos. 12 propriedades estavam em Piracicaba, onde os trentinos fundaram sua colônia nos anos 1890, ou em municípios próximos, como Rio Claro e Rio das Pedras. Outros 16 colonos trentinos adquiriram terras nas municipalidades das antigas colônias, Campinas e Amparo, bem como na vizinhança, em Serra Negra, Itapira e Itatiba. Apenas três adquiriram propriedades em áreas mais distantes, em São José do Rio Pardo, Dois Córregos e Botucatu. Todos os 31 proprietários trentinos possuíam pequenas e médias propriedades, voltadas ao café e ao cultivo de alimentos. O número de proprietários aqui encontrado pode estar subestimado já que, como visto, era comum a prática de compra em conjunto de propriedades.

Diferentemente dos alemães, os austríacos - e em especial esses da região de Trento/Tirol - parecem ter sido mais bem-sucedidos no acesso à terra. Foi possível encontrar $27 \%$ dos imigrantes em trânsito pela Hospedaria dentre os listados como proprietários em 1905, além de imigrantes chegados em períodos anteriores, nas primeiras experiências com trabalhadores livres. O associativismo - a compra de terras em conjunto, a ajuda mútua entre familiares e conterrâneos - parece ter colaborado para que os austríacos tivessem mais chances de acesso à terra, o mesmo que o observado para os espanhóis.

\section{Conclusões}

Este capítulo foi iniciado com a apresentação de uma petição de fazendeiros sãocarlenses feita ao Secretário da Agricultura em 1913 solicitando a promoção da imigração asiática, visto que os imigrantes europeus localizados na região haviam todos se tornado proprietários de terra, graças aos bons salários pagos pelos fazendeiros. Colocou-se em dúvida como talvez exagerado o cenário descrito pelos fazendeiros sãocarlenses. Claramente, não é correto dizer que as oportunidades foram iguais para todos os colonos estrangeiros e que a compra de uma propriedade rural era uma realidade generalizada. Por outro lado, não é possível afirmar que todos os imigrantes chegados 
com subsídios para o trabalho nas fazendas depararam-se com condições tão adversas que tornaram impossível a aquisição de terras.

Os autores pessimistas e otimistas apresentados neste capítulo oferecem argumentos válidos, mas que são ainda, em grande medida, hipóteses, e nenhuma parece poder ser tomada de forma absoluta para todos os períodos e todas as nacionalidades. Diversos relatos de cônsules, representantes de governos e viajantes que visitaram fazendas no interior do estado no começo do século XX afirmam que, apesar das condições difíceis enfrentadas pelos colonos, havia, em uma mesma região, famílias que trabalhavam e logravam acumular pecúlio e adquirir terras, enquanto outras não eram tão bem-sucedidas. ${ }^{68}$

Ao longo do capítulo, buscou-se averiguar se o acesso à terra pelos imigrantes que passaram pela Hospedaria de Imigrantes, estrangeiros pobres vindos em sua grande maioria com subsídios do governo de São Paulo em busca de uma vida melhor, foi uma realidade. Com esse objetivo, foram cruzados os nomes dos imigrantes listados como proprietários de terra na Estatística Agrícola de 1905 com os registros de matrícula dos imigrantes da Hospedaria de Imigrantes de São Paulo entre 1884 e 1904. Nesses 20 anos, passaram pela Hospedaria de Imigrantes mais de 650.000 estrangeiros. O recenseamento das propriedades rurais feito pela Secretaria da Agricultura em 1905 revelou a existência de 6.144 propriedades de estrangeiros. Foi possível localizar, através do modelo de matching adotado, 657 desses proprietários. ${ }^{69}$

Os dados obtidos na amostra indicam que $70 \%$ dos imigrantes proprietários localizados passaram pela Hospedaria entre 1890 e 1899, sugerindo que imigrantes que conseguiram comprar terras não o fizeram logo após sua chegada a São Paulo e que o tempo médio de trabalho antes do imigrante acumular pecúlio suficiente girava em torno de dez anos. A vasta maioria dos imigrantes localizados $(90,8 \%)$ eram homens registrados como chefes de família, corroborando as afirmações da historiografia que o imigrante vindo em família, com todos os membros aptos ao trabalho no campo, teria mais facilidade de acumular pecúlio e adquirir terras. Apesar de não haver informação de ocupação para metade da amostra obtida, $41 \%$ dos proprietários mapeados eram agricultores. Não parece incorreto supor que a grande maioria dos imigrantes para os quais não há informação de ocupação fosse também formada por agricultores, dadas as

\footnotetext{
${ }^{68}$ Savioa, "Lo stato," 203; 210.

${ }^{69}$ Excluindo os portugueses.
} 
regras da política de subsídios implementada pelo governo de São Paulo. Nesse último ponto, a hipótese levantada por alguns autores, de que parte dos imigrantes que adquiriram terras não teriam sido os vindos para o trabalho no campo, com exceção do caso alemão, não parece se sustentar na amostra aqui apresentada.

Outra questão importante verificada na amostra obtida foi a mobilidade geográfica dos imigrantes proprietários. 95\% deles obtiveram terras em municípios diferentes dos quais se dirigiram inicialmente para o trabalho nas fazendas, parecendo ter sido mais fácil comprar terras nas regiões onde o café ainda estava ganhando presença na época, como a Araraquarense e a Alta Sorocabana. Tal fato sugere que o sucesso dos imigrantes era em grande medida dependente de conseguirem deslocar-se para regiões em que encontravam melhores condições para adquirir terra.

Apesar do resultado geral apontar que apenas $10 \%$ dos imigrantes proprietários rurais em 1905 haviam passado pela Hospedaria de Imigrantes, quando observados os resultados por nacionalidade, o cenário é diferente. Neste capítulo, analisou-se também os resultados da amostra para quatro nacionalidades: os italianos, os espanhóis, os alemães e os austríacos. A partir dessa análise, concluiu-se que a aquisição de terras pelos imigrantes da Hospedaria variou conforme a origem.

Os italianos foram o maior grupo de estrangeiros com entrada pela Hospedaria e que figuraram como proprietários na Estatística Agrícola de 1905. No procedimento de correspondência efetuado no capítulo, dos 4.823 proprietários rurais italianos do estado de São Paulo, 9,8\% passaram pela Hospedaria de Imigrantes. As propriedades identificadas se concentraram nas regiões cafeeiras da Mogiana e da Araraquarense, além da Central. O tamanho médio das terras era de 26 alqueires e seus proprietários haviam chegado ao estado no auge da expansão cafeeira dos anos 1890 , quando as remunerações pagas eram maiores e as possibilidades de pecúlio parecem ter sido mais favoráveis, permitindo aquisição de terra nas regiões cafeeiras para os italianos.

Já no caso dos espanhóis, segundo grupo analisado, obteve-se maior percentual de proprietários localizados entre todas as nacionalidades analisadas, 33,6\% dos 411 donos de terras listados na Estatística Agrícola de 1905. Imigrantes tardios, é possível que os contratos firmados pelos espanhóis nas lavouras cafeeiras não tenham sido tão vantajosos ou com salários no mesmo nível que os encontrados pelos italianos chegados no início da imigração em massa para São Paulo. Para os espanhóis, também, o retorno 
à pátria não parece ter sido uma alternativa. Esses dois fatores combinados podem explicar o resultado obtido na amostra. Adquirindo propriedades pequenas, com tamanho médio de 17,7 alqueires, localizadas na fronteira agrícola do estado, em regiões como a Noroeste, Alta Sorocabana e Araraquarense onde a terra era mais barata, os espanhóis imigrantes em São Paulo buscavam investir no próprio estado seus ganhos como colonos nas fazendas.

Para os alemães que chegaram a São Paulo durante a imigração em massa, o resultado obtido demonstra que a compra de uma propriedade rural não foi uma realidade frequente. Foram localizados nos registros da Hospedaria apenas 3,2\% dos proprietários listados na Estatística Agrícola de 1905. Talvez surpreendentemente, foram encontrados como proprietários rurais no estado os alemães chegados anteriormente, na década de 1850, para as primeiras experiências com trabalho livre nas fazendas lideradas por Ibicaba, de propriedade do Senador Vergueiro.

O caso dos austríacos foi um dos mais interessantes. Dos 89 proprietários rurais austríacos em São Paulo em 1905, 24 (27\%) haviam passado pela Hospedaria, a segunda maior correspondência da amostra, atrás apenas dos espanhóis. Cruzando listas de colonos que migraram entre 1877 e 1883 para o trabalho nas colônias de Saltinho e Santo Grande, foi possível identificar cinco desses colonos e 26 possíveis descendentes. As propriedades dos austríacos localizados foram, ao lado das adquiridas pelos alemães, as maiores da amostra, com tamanho médio de 40 alqueires.

Um resultado final importante do capítulo foi que, nos dois casos com maior correspondência da amostra (os espanhóis e os austríacos), o associativismo - a compra de terras em conjunto, a ajuda mútua entre familiares e conterrâneos - parece ter colaborado substancialmente para que tivessem mais chances de acesso à terra. 


\section{CONCLUSÕES GERAIS}

O objetivo desta tese foi tratar das políticas fundiárias, das propriedades rurais de imigrantes e da mobilidade econômica dos imigrantes por meio do acesso à terra no estado de São Paulo entre 1886 e 1920. Ao longo do século XIX e começo do XX, os temas imigração e acesso à terra estiveram entrelaçados intimamente. No período, coexistiu o debate na política paulista entre promoção da imigração para a colonização e como alternativa à escassez de trabalho esperada nas fazendas após o fim da escravidão.

No primeiro capítulo, foi mostrada justamente a relação entre as políticas de terra e imigração na província de São Paulo na visão dos diversos atores que compunham o governo e a elite paulista, através de debates e posições de políticos e fazendeiros durante todo o século XIX e começo do XX. A ideia de se estabelecer imigrantes como proprietários rurais remonta às primeiras iniciativas de colonização propostas pelo governo provincial e se estenderam por todo o período estudado. Personagens contrários a essa política, em especial na elite agrária, argumentavam que o país necessitava de braços para a lavoura e não de povoamento. No entanto, a análise realizada dos debates políticos travados na Assembleia Legislativa de São Paulo, nos jornais da época, assim como nos discursos dos presidentes de província (e, posteriormente, estado) e dos secretários da agricultura, revelou que existiram vozes que defendiam o acesso à terra pelos imigrantes. Ainda assim, para essas poucas vozes o acesso à propriedade deveria ocorrer em sintonia com os interesses dos cafeicultores, servindo para fixar o imigrante na terra, como reserva de mão de obra para as fazendas na época das colheitas e para diminuir os custos dos fazendeiros com o colonato.

Nos anos 1880, duas sociedades de promoção à imigração se destacaram nos debates públicos: a Sociedade de Imigração de São Paulo - filial paulista da Sociedade Central de Imigração, com sede no Rio de Janeiro - e a Sociedade Promotora de Imigração - formada pelos cafeicultores e políticos paulistas. A defesa do acesso à pequena propriedade por estrangeiros foi marca característica da Sociedade de Imigração. A Sociedade Promotora foi responsável por articular entre o governo de São Paulo e os cafeicultores todo o serviço de introdução de imigrantes para o trabalho nas fazendas, relegando a segundo plano a questão da aquisição de terra por esses indivíduos. A existência da Sociedade Promotora garantiu que o sistema de imigração 
de São Paulo continuasse sem grandes problemas durante a transição do Império para a República. atendendo os principais interesses dos grandes proprietários de terra.

Com a promulgação da Constituição de 1891, as terras devolutas passaram para os estados e estes tiveram liberdade para legislar em matéria fundiária e de imigração. As leis de terras aprovadas no estado de São Paulo nada mais foram do que continuações da política vigente na época imperial e pouco inovaram sobre o acesso à terra pelos imigrantes. Os projetos de lei propostos que tratavam da doação de terra a estrangeiros, ou que propunham a alienação da terra com o objetivo de incentivar a vinda e criar uma corrente imigratória para o estado, não tiveram vez no parlamento. A visão que predominou era a de que o imigrante deveria chegar em São Paulo comprometido com o trabalho nas grandes fazendas cafeeiras, onde se aclimataria e acumularia pecúlio para, com o tempo, adquirir uma propriedade rural. Apenas ao longo das primeiras décadas do século XX as elites política e agrária se deram conta que era necessário fazer algo mais e incluir o acesso à terra como forma de atrair e manter os imigrantes. O governo paulista passou a atuar na fundação de núcleos coloniais e a incentivar o parcelamento e loteamento das áreas impróprias para o café das grandes fazendas e o assentamento de imigrantes em pequenos lotes de terra. Dessa forma, a elite cafeeira garantiria para si as melhores terras e teria uma reserva de trabalhadores na época das colheitas. O ideário que norteava a formação da pequena propriedade para os imigrantes era um só: servir aos interesses dos grandes cafeicultores.

Apesar da visão dominante da imigração para o trabalho nas fazendas e das políticas restritivas de acesso à terra, muitos imigrantes de fato conseguiram se tornar proprietários rurais em São Paulo no começo do século XX. Como o fim de estudar essas propriedades rurais de estrangeiros em São Paulo, um primeiro passo foi mapear o fluxo e localização dos imigrantes no estado, trabalho este realizado no Capítulo 2. Havia uma lacuna nos dados oficiais sobre a localização dos imigrantes em São Paulo no início do programa de subsídios. Dessa forma, usando uma fonte ainda pouco explorada pela historiografia, os registros de matrícula da Hospedaria de Imigrantes, foi possível mapear o destino tomado pelos imigrantes da Hospedaria para municípios e regiões de São Paulo. Esses registros foram transcritos pelos funcionários do Arquivo Público do Estado de São Paulo, mantendo as informações originais contidas nos livros de matrícula, dando origem a uma base de dados com 1,5 milhão de observações. Após limpeza, sistematização e organização dessa base, foi possível traçar um panorama 
detalhado do movimento dos imigrantes em São Paulo para todo o período estudado, de 1886 até 1920.

Como esperado, os imigrantes da Hospedaria tiveram como principal destino as regiões cafeeiras do estado. Se entre 1886 e 1900 a Mogiana e a Paulista eram as regiões que mais receberam esses imigrantes, de 1901 a 1920 nota-se um deslocamento para as zonas da Araraquarense, Alta Sorocabana e, mais tarde, Noroeste, conforme o café se espalhava pelo estado. Por meio da análise da distribuição desses imigrantes entre as diversas regiões do estado ao longo do tempo, foi possível verificar a tendência de concentração de algumas nacionalidades em determinadas regiões. Foi possível, também, acompanhar o deslocamento da onda migratória, sempre em direção à fronteira agrícola do estado do período analisado.

A seguir, no Capítulo 3, outras questões importantes foram abordadas: quantos, onde se localizavam e de quais nacionalidades eram os proprietários de terra estrangeiros em São Paulo. Com a Estatística Agrícola de 1905 e o recenseamento agrícola do Censo de 1920, foi traçado um quadro da participação dos imigrantes na agricultura paulista do começo do século XX. Se, em 1905, os estrangeiros possuíam $15 \%$ das propriedades rurais e controlavam 9\% das terras do estado de São Paulo em mãos de particulares, em 1920 esses percentuais passaram para, respectivamente, 27,2\% e 14\%. O número de propriedades de estrangeiros no período aumentou em 2,6 vezes, enquanto o número de propriedades de brasileiros aumentou em apenas $30 \%$.

Em 1905, as propriedades rurais dos estrangeiros encontravam-se principalmente nas regiões de fronteira agrícola ou onde o café começava a perder importância, possivelmente por serem estas regiões onde as terras eram mais baratas. Na região da Araraquarense localizavam-se $20 \%$ desses estabelecimentos, seguida pela Paulista com $18 \%$ e Central, com 17,3\%. Na Mogiana, principal região cafeeira naquele ano, havia apenas $14,8 \%$ das propriedades dos imigrantes. O Censo de 1920 indicou uma mudança no perfil de localização dessas propriedades. Ainda que Araraquarense, Paulista e Mogiana seguissem sendo as principais regiões onde os imigrantes adquiriram propriedades, houve uma diminuição na participação de estrangeiros entre os donos de estabelecimentos rurais nas duas últimas e um deslocamento em direção às regiões de fronteira agrícola, isto é, a Alta Sorocabana e a Noroeste. Tanto em 1905 quanto em 1920, regiões onde o café não predominava e para onde poucos imigrantes haviam ido quase não registraram propriedades rurais de estrangeiros. 
Um coeficiente simples (Spearman) permitiu analisar a correlação entre, de um lado, a quantidade de propriedades de imigrantes em relação ao total de propriedades rurais em cada município paulista e, de outro, as áreas cultivadas com café, milho, feijão e arroz em relação à área cultivada total em cada município, em 1905 e 1920. Os resultados confirmaram a tendência dos estrangeiros acompanharem a expansão da fronteira agrícola em São Paulo na aquisição de suas propriedades rurais. Foi calculado também um índice que relacionou o número de propriedades de uma nacionalidade específica em uma região do estado de São Paulo e o total de propriedades daquela nacionalidade no estado. Os resultados mais uma vez confirmaram, tanto para 1905 quanto para 1920, a presença de propriedades de estrangeiros acompanhando o deslocamento do cultivo cafeeiro no estado.

As pequenas e médias propriedades somavam 92,4\% do total das propriedades dos estrangeiros em São Paulo em 1905. A grande presença de propriedades pequenas e médias entre os estrangeiros proprietários não significou, contudo, uma distribuição mais equitativa da terra. Os pequenos e médios proprietários dominavam apenas $33,1 \%$ da área total e 56,3\% da área cultivada. Os poucos estrangeiros que figuravam entre os latifundiários, com propriedades com mais de 100 alqueires, controlavam mais de $40 \%$ da área total, ainda que cultivassem apenas $16 \%$ do total da área cultivada. Surpreendentemente, a distribuição de terras entre estrangeiros se mostrou até mesmo mais desigual que entre os brasileiros. O cálculo do coeficiente de Gini resultou em 0,789 para todas as propriedades de estrangeiros. O mesmo cálculo, considerando apenas as propriedades dos nacionais, indicou um coeficiente menor, de 0,776.

A análise dos dados revelou que os proprietários estrangeiros faziam um uso mais intensivo de suas terras, cultivando, em média, 18,3\% da área total, frente a apenas $12,5 \%$ no caso dos nacionais. Observou-se, também, que, em comparação aos proprietários brasileiros, os estrangeiros dedicavam maiores parcelas de suas terras para o cultivo tanto do café quanto de culturas alimentares. Em termos de produção, os estrangeiros cultivaram $15 \%$ do café, $12 \%$ de todo o milho, $14,5 \%$ do feijão e $17,5 \%$ do arroz produzidos no estado de São Paulo em 1905. Os dados revelaram também que $40 \%$ de toda a cana-de-açúcar produzida no estado vieram de propriedades de estrangeiros. O Censo de 1920, por não apresentar a produção de cada gênero agrícola em cada município por nacionalidade, não permitiu avaliar a produção das propriedades pertencentes aos estrangeiros. No entanto, um levantamento do Ministério da 
Agricultura sobre a produção cafeeira em São Paulo realizado em 1923 demonstrou que $30 \%$ dos pés de café e $40 \%$ das propriedades rurais produzindo café pertenciam a estrangeiros. Esses números, novamente, parecem surpreendentes e uma indicação da extensão da propriedade de terra por imigrantes, a despeito das restrições e falta de políticas públicas de acesso à terra no início da grande imigração.

No quarto e último capítulo desta tese, buscou-se examinar se os estrangeiros pobres, vindos em sua grande maioria com os subsídios oferecidos pelo governo de São Paulo, conseguiram a tão almejada aquisição de terras. Para alcançar esse objetivo, foi realizado o cruzamento entre os nomes dos 6.144 proprietários estrangeiros de terra listados na Estatística Agrícola de 1905 e os de mais de 650.000 imigrantes da Hospedaria de Imigrantes registrados entre 1884 e 1904. Pelo procedimento de matching entre as bases de dados, obteve-se uma amostra com 657 indivíduos, pouco mais de $10 \%$ dos estrangeiros donos de terra em 1905 que também foram localizados nos registros da Hospedaria.

A amostra obtida permitiu analisar diversas características dos imigrantes proprietários. Foi possível observar que o acesso à terra demandou tempo, já que $70 \%$ dos proprietários localizados passaram pela Hospedaria entre 1890 e 1899. As afirmações da historiografia sobre o imigrante com família ter mais condições de acumular pecúlio e adquirir terra encontram respaldo na análise amostra, uma vez que 90,8\% dos imigrantes proprietários identificados eram chefes de família. Alguns autores argumentam que parte dos imigrantes que conseguiram comprar terras não seria os que foram para o trabalho nas fazendas. Porém, essa hipótese que não se sustenta na amostra obtida, pois $41 \%$ dos proprietários mapeados eram de fato agricultores. Apesar de não existir a informação sobre a ocupação para metade da amostra, não seria incorreto assumir, em vista das regras da política de subsídios do governo, que a maioria também era de agricultores. A mobilidade geográfica dos imigrantes, outro ponto apontado pela historiografia, foi verificada na amostra: 95\% dos imigrantes proprietários adquiriram terras em municípios distintos dos quais se dirigiram inicialmente para o trabalho nas fazendas. Mais ainda, a amostra indica que parece ter sido mais fácil a aquisição de propriedades rurais onde o café ainda estava ganhando espaço em 1905, como as regiões da Araraquarense e a Alta Sorocabana.

Os resultados apresentados no capítulo contribuem também com respostas para um dilema clássico da literatura sobre o tema: se esses imigrantes subsidiados, mais 
pobres, tiveram ou não condições de se tornarem proprietários rurais. Apesar do resultado do matching ter sido baixo, a amostra obtida parece confirmar o que afirmavam os autores mais otimistas: não obstante os percalços sofridos, o acesso à terra era uma possibilidade real aberta para os colonos estrangeiros. Ainda assim, essa realidade variou de acordo com as nacionalidades.

Quando observados os resultados encontrados por nacionalidades, nota-se que para os colonos alemães chegados durante o período da grande migração a possibilidade de adquirir terras parece ter sido mínima. Por sua vez, os espanhóis enfrentaram uma situação exatamente oposta, pois $33 \%$ proprietários dessa nacionalidade foram localizados na Hospedaria. Para os italianos, maior grupo de estrangeiros a entrar no estado entre 1886 e 1920, o acesso à terra parece ter ocorrido apenas para uma parte dos colonos. Com relação aos austríacos que se tornaram proprietários, $28 \%$ passaram pela Hospedaria de Imigrantes. Foi possível averiguar também que, em 1905, havia proprietários imigrantes que chegaram em São Paulo tão cedo quanto 1850, como no caso de alguns alemães colonos da fazenda Ibicaba, ou 1877, no caso dos austríacos colonos em Salto Grande e Saltinho, na região de Campinas. Não apenas parte desses ex-colonos, mas seus possíveis descendentes aparecem como proprietários de terra em 1905 no estado de São Paulo.

Nos 34 anos analisados nesta tese foi possível ver a consolidação dos estrangeiros que se tornaram proprietários e sua crescente importância na participação da agricultura paulista. Os resultados obtidos mostram que não houve mudanças substancial da ordem agrária vigente, não houve substituição das grandes propriedades pelas pequenas ou uma diminuição da importância da produção cafeeira no período analisado. Houve, por outro lado, uma evolução da situação do imigrante, que se mostrou capaz de ocupar um lugar crescente entre os proprietários rurais de São Paulo. Apesar dos interesses dos grandes fazendeiros, ou por conta deles, os imigrantes parecem ter alcançado em número expressivo o sonho que os motivou a emigrar, ou seja, a aquisição de um pedaço de terra e possivelmente melhores condições de vida.

Os dados e análise que aqui foram apresentados poderão servir para futuros estudos comparativos sobre imigração e estrutura fundiária em outras regiões da América Latina e, mais amplamente, podem contribuir para o estudo da desigualdade no acesso à terra e seus efeitos no longo prazo. Outros trabalhos utilizando a mesma 
técnica de cruzamento de dados empregada nesta tese poderão ajudar a verificar a mobilidade socioeconômica dos imigrantes em outros ramos fora do meio rural. 


\section{REFERÊNCIAS}

\section{Fontes Primárias}

Assembleia Legislativa de São Paulo (ALESP). Câmara dos Deputados de São Paulo. $\begin{array}{llllll}\text { Projecto } & n & & \end{array}$ de Disponível em: https://www.al.sp.gov.br/repositorioAH/Acervo/Alesp/Documentos/C_1t017/0007 1895.pdf. Acesso em: 27 nov. 2018.

Assembleia Legislativa de São Paulo (ALESP). Projeto n. 206 de 1896. Manda executar com alterações a Lei $n .323$ de 22 de junho de 1895 e respectivo regulamento $n .343$ de 10 de março de 1896. Disponível em: https://www.al.sp.gov.br/repositorioAH/Acervo/Alesp/Documentos/C 1t024/0206 1896.pdf, Acesso em: 22 mai. 2018.

Assembleia Legislativa de São Paulo (ALESP). Parecer n. 60 da Comissão de Obras Públicas e Fazenda, 19 de junho 1899. Disponível em: https://www.al.sp.gov.br/repositorioAH/Acervo/Alesp/Documentos/115/0007_18 95.pdf Acesso em: 12 nov. 2018.

Assembleia Legislativa de São Paulo (ALESP). Projeto n. 3, de 1901, do Senado. Disponível em: https://www.al.sp.gov.br/repositorioAH/Acervo/Alesp/Documentos/136/0003_190 1.pdf, Acesso em: 29 jan. 2019.

Assembleia Legislativa de São Paulo (ALESP). Projeto n. 3-A, de 1901, do Senado. Disponível em: https://www.al.sp.gov.br/repositorioAH/Acervo/Alesp/Documentos/136/003A_19 01.pdf. Acesso em: 29 jan. 2019.

Assembleia Legislativa de São Paulo (ALESP). Lei n 1045-C de 27 de dezembro de 1906, dispõe sobre a imigração e colonização no território do Estado. Disponível em: $\quad$ https://www.al.sp.gov.br/repositorio/legislacao/lei/1906/lei-1045C27.12.1906.html Acesso em: 05 dez. 2018.

Assembleia Legislativa de São Paulo (ALESP). Parecer n. 16 de 1907 das Comissões de Obras e Justiça, 19 de julho de 1907. Disponível em: https://www.al.sp.gov.br/repositorioAH/Acervo/Alesp/Documentos/115/0007_189 5.pdf Acesso em: 12 nov. 2018.

Assembleia Legislativa de São Paulo (ALESP). Parecer n. 53 da Commissão de Colonização, Terras Públicas e Minas do Senado 25 de novembro de 1914. Disponível

em: https://www.al.sp.gov.br/repositorioAH/Acervo/Alesp/Documentos/CX_117/0022 1914.pdf Acesso em: 18 dez. 2018.

Assembleia Legislativa de São Paulo (ALESP). Parecer n. 15 de 1925, Comissão de Agricultura $e$ Fazenda. Disponível em: https://www.al.sp.gov.br/repositorioAH/Acervo/Alesp/Documentos/046/0006_191 4.pdf Acesso em: 20 nov. 2018.

Assembleia Legislativa de São Paulo (ALESP). Representação dos habitantes da vila de Campos Novos do Paranapanena sobre terras devolutas naquela localidade. 19 de abril de $1895 . \quad$ Disponível em: https://www.al.sp.gov.br/repositorioAH/Acervo/Alesp/Documentos/129/0015 189 3.pdf Acesso em: 19 maio 2018. 
Brasil. Anais da Câmara dos Deputados. Disponível em: http://imagem.camara.leg.br/pesquisa_diario_basica.asp. Múltiplos acessos.

Brasil. Annaes do Senado do Imperio do Brazil, Segunda Sessão da Primeira Legislatura de 27 de abril a 14 de junho de 1827. Rio de Janeiro, 1910. Livro 1.

Brasil. Annaes do Senado do Imperio do Brazil, Segunda Sessão da Primeira Legislatura de 16 de junho a 12 de setembro de 1827. Rio de Janeiro, 1910. Livro 2.

Brasil. Annaes do Senado do Imperio do Brazil, Segunda Sessão da Primeira Legislatura de 27 de abril a 20 de junho de 1830. Rio de Janeiro, 1914. Livro 1.

Brasil. Anais do Senado do Império do Brasil. Anno de 1848. Brasília: Senado Federal, 1978. Livro 5.

Brasil, Ministério da Viação e Obras Públicas, Estatística das estradas de ferro do Brasil, relativa ao ano de 1920. Rio de Janeiro: Soares Dias \& C., 1924.

Brasil. Fallas do Throno desde o anno de 1823 até o anno de 1889. Rio de Janeiro: Imprensa Nacional, 1889.

Brasil. Collecção das Leis do Imperio do Brazil de 1808. Rio de Janeiro: Imprensa Nacional, 1891.

Brasil. Ministerio da Agricultura. Industria e Commercio. Directoria Geral de Estatistica - Recenseamento do Brazil - realizado em 1 de Setembro de 1920. V. III. 1 e 2 parte. Rio de Janeiro: Typ. Da Estatistica. 1923.

São Carlos. Representação a favor da imigração japonesa, 1912, Fundo Secretaria da Agricultura, Acervo APESP, cx. 3.7.1435, doc. 25.

São Paulo. Annaes da Assembleia Legislativa Provincial de São Paulo, 1889.

São Paulo. Relatorio com que o Exmo. Sr. Dr. José Luiz de Almeida Couto, presidente da província de São Paulo, passou a administração ao 1 Vice-Presidente Exmo. Sr. Dr. Francisco Antonio de Souza Queiroz Filho. São Paulo: Typographia do Correio Paulistano, 1886.

São Paulo. Relatorio apresentado á Assembléa Legislativa Provincial de São Paulo pelo presidente da provincia, Barão do Parnahyba, no dia 17 de janeiro de 1887. São Paulo: Typ. a Vapor de Jortge Seckler \& Comp., 1887.

São Paulo. Relatório com que o Dr. Francisco de Paula Rodrigues Alves passou a administração da Província de São Paulo ao Dr. Francisco Antônio Dutra Rodrigues, $1^{o}$ vice-presidente, no dia 27 de abril de 1888. São Paulo: Seckler, 1888.

São Paulo. Relatório apresentado ao Exm. Sr. Presidente da Província de São Paulo pela Commissão Central de Estatistica. São Paulo: Leroy King Bookwalter, Typographia King, 1888.

São Paulo. Câmara dos Deputados de São Paulo. Projecto n. 7 de 1895 Disponível em: https://www.al.sp.gov.br/repositorioAH/Acervo/Alesp/Documentos/C_lit017/0007 1895.pdf. Acesso em: 27 nov. 2018.

São Paulo. Relatório apresentado ao cidadão Dr. Presidente do Estado pelo Dr. Theodoro Dias de Carvalho Junior, ano de 1895. São Paulo: Typ. A Vap.Espindola, Siqueira \& Comp., 1896. 
São Paulo. Boletim da Agricultura $2^{\mathrm{a}}$ série, n. 1, anno de 1901. São Paulo: Red. da Revista Agrícola, 1901.

São Paulo. Relatório apesentado ao Dr. Domingos Correa de Matos, Vice-Presidente do Estado pelo Dr. Antonio Candido Rodrigues, Secretário da Agricultura, ano de 1901. São Paulo: Typ. Diario Oficial, 1902.

São Paulo. Relatório do anno de 1900 apresentado em 13 de janeiro de 1902 ao cidadão Dr. Bento Pereira Bueno, Secretário de Estado dos Negócios do Interior e da Justiça, pelo Dr. Antonio de Toledo Piza, Director. São Paulo: Typ do Diario Official, 1903.

São Paulo. Relatório apesentado ao Dr. Bernardino de Campos, Presidente do Estado pelo Dr. João Batista de Mello Peixoto, Secretário da Agricultura, ano de 1902. São Paulo: Typ. Diario Oficial, 1903.

São Paulo. Relatório de 1903 pelo Dr. Luiz de T. Piza e Almeida, Secretário da Agricultura. São Paulo: Typ. Diario Oficial, 1904.

São Paulo. Decreto n. 1.323, de 23 de Outubro De 1905. Approva as instrucções para o levantamento da estatistica agricola e zootechnica do Estado de São Paulo. Disponível

em:

https://www.al.sp.gov.br/repositorio/legislacao/decreto/1905/decreto-1323-

23.10.1905.html Acesso em: 26 fev. 2019.

São Paulo. Secretaria de Agricultura, Commercio e Obras Públicas do Estado de São Paulo. Estatistica agricola e zootechnica do estado de São Paulo no anno agricola de 1904-1905. São Paulo: Tip. Brazil, 1907.

São Paulo. Secretaria de Agricultura, Commercio e Obras Públicas do Estado de São Paulo. Estatistica Agrícola e Zootechnica 1934-1935. São Paulo: Directoria de Estatística, Indústria e Commercio, 1936.

São Paulo. Secretaria dos Negócios da Agricultura, Comércio e Obras Públicas do Estado de São Paulo. Relatório apresentado ao Dr. Jorge Tibiriçá, Presidente do Estado, pelo Dr. Carlos Botelho, Secretário da Agricultura. Anno de 1906. São Paulo: Typographia Brazil de Rothschild \& Co. 1907.

São Paulo. Secretaria da Agricultura, Commercio e Obras Públicas, Departamento Estadual do Trabalho. A Imigração e as condições do trabalho em São Paulo. São Paulo: Typ Brasil, de Rothschild \& cia. 1915.

São Paulo, Secretaria da Agricultura, Commercio e Obras Públicas do Estado. Boletim do Departamento Estadual do Trabalho 5, n. 19, $2^{\circ}$ trim. 1916.

São Paulo. Secretaria de Estado dos Negocio da Agricultura, Commercio e Obras Pública, Parecer n. 1572, de 17 de julho de 1916. Disponível em: https://www.al.sp.gov.br/repositorioAH/Acervo/Alesp/Documentos/046/0006_191 4.pdf Acesso em: 20 nov. 2018.

São Paulo. Repartição de Estatística e Archivo de São Paulo. Annuario Estatístico de São Paulo (Brasil). Diversos anos.

São Paulo, Departamento Estadual De Estatística, Anuário Estatístico do Estado de São Paulo. v. 1 - Estatísticas físicas, demográficas, sociais e culturais. Ano de 1944. São Paulo: Industria Gráfica Siqueira S/A, 1948. 
São Paulo. "Livros de Registro da Hospedaria de Imigrantes." Disponível em: http://www.arquivoestado.sp.gov.br/site/acervo/memoria_do_imigrante/pesquisa_li vros_Hospedaria.

Sociedade Promotora de Immigração de S. Paulo. Relatório apresentado ao Ilmo. E Exmo. Sr. Visconde de Parnahyba Presidente da Província de São Paulo pela Sociedade Promotora de Immigração. In Exposição com que o Exmo. Sr. Visconde de Parnahyba passou a administração da Província de São Paulo ao Exm. Sr. Dr. Francisco de Paula Rodrigues Alves Presidente desta Provincia no dia 19 de novembro de 1887. São Paulo: Typ. Jorge Seckler \& Comp. Anexo A4, 1888.

Sociedade Promotora de Immigração de S. Paulo. Relatorio da Directoria ao Exm. Sr. Conde de Parnahyba, presidente da Provincia de S. Paulo. São Paulo: Typ. Jorge Seckler \& Comp, 1888.

Sociedade Promotora De Imigração. Actas. Manuscrito. Arquivo do Estado de São Paulo (AESP). Fundo Imigração, C05529.

\section{Jornais}

A Immigração

Gazetta de Campinas

A Província de São Paulo

O Estado de São Paulo

Correio Paulistano

\section{Sites}

“Estações ferroviárias do Brasil.” Múltiplos acessos. http://estacoesferroviarias.com.br/.

“Cidades@.”Múltiplos acessos. https://cidades.ibge.gov.br/.

"Histórico da Formação dos Municípios." Múltiplos acessos. http://produtos.seade.gov.br/produtos/500anos/index.php?tip=hist.

\section{Bibliografia}

Abrahão, Fernando Antônio. "Padrões de riqueza e mobilidade social na economia cafeeira: Campinas, 1870-1940.” Tese de Doutorado, FFLCH-USP, 2015.

Abramitzky, Ran et al. "Automated Linking of Historical Data." NBER Working Paper No. 25825 (Jun. 2020).

Abramitzky, Ran, Leah Platt Boustan, e Katherine Eriksson. "A Nation of Immigrants: Assimilation and Economic Outcomes in the Age of Mass Migration." Journal of Political Economy 122, n. 3 (June/2014): 467-506.

Abramitzky, Ran, Leah Platt Boustan, e Katherine Eriksson. "Europe's Tired, Poor, Huddled Masses: Self-Selection and Economic Outcomes in the Age of Mass Migration." American Economic Review 102 (2012): 1832-56. 
Abramitzky, Ran, Leah Platt Boustan, e Katherine Eriksson. "Have the poor always been less likely to migrate? Evidence from inheritance practices during the Age of Mass Migration.” Journal of Development Economics 102 (2013): 2-14.

Abramitzky, Ran, Roy Mill, and Santiago Pérez. "Linking Individuals Across Historical Sources: a Fully Automated Approach.” Historical Methods (April, 2019): 94-111.

Amaral, José Bonifácio do, Visconde de Indaiatuba. "Introdução ao trabalho livre em Campinas." In Monografia histórica do município de Campinas, organizado por Carlos Francisco de Pádua, 243-55. Rio de Janeiro: Serviço Gráfico do IBGE, 1952.

Andrada e Silva, Raul de. "José Bonifácio, o pensador reformista." Revista de História 45, n. 92 (1972): 403-9.

Assis Brasil, Joaquim. Do Governo Presidencial na Republica Brasileira. Lisboa: Companhia Editora Nacional, 1896.

Bacellar, Carlos de Almeida Prado. "O apogeu do café na Alta Mojiana." In Na estrada do Anhanguera: uma visão regional da história paulista, organizadores Carlos de Almeida Prado Bacellar e Lucilia Reis Brioschi. São Paulo: Humanitas, 1999.

Bassanezi, Maria Silvia C. B e Rosana Baeninger. "Uma fonte para os estudos de população: os registros da Hospedaria de imigrantes de São Paulo." Textos NEPO, n. 7 (Jun. 1986): 25-40.

Bassanezi, Maria Silvia C. B. "Fazenda Santa Gertrudez: uma abordagem quantitativa das relações de trabalho em uma propriedade rural paulista, 1895-1930." Tese de Doutorado, UNESP, Rio Claro, 1973.

Bassanezi, Maria Silvia C. B. "Família e força de trabalho no colonato. Subsídios para a compreensão da dinâmica demográfica no período cafeeiro." Textos NEPO, n. 8 (Jul. 1986).

Bassanezi, Maria Silvia C. B. et al. Repertório de legislação brasileira e paulista referente à imigração. São Paulo: Editora Unesp/Fapesp, 2008.

Bassanezi, Maria Silvia C. B., et al. Atlas da imigração internacional em São Paulo, 1850-1950. São Paulo: UNESP, 2008.

Bassanezzi, Maria Silvia C. B. e Priscila M. S. Francisco (Eds.). Estado de São Paulo: Estatística agrícola e zootécnica, 1904-1905 [CD-ROM]. Campinas: Nepo/Unicamp, 2003.

Beiguelman, Paula. “A Grande Imigração em São Paulo II.” Revista de História (1968): 145-57.

Beiguelman, Paula. Formação do Povo no Complexo Cafeeiro: aspectos políticos. São Paulo: Pioneira, 1975.

Botella, Cristóbal. El problema de la emigración. Madrid: Tipografia de los huérfanos, 1888.

Brioschi, Lucila R. "Fazendas de Criar." In Na Estrada do Anhangüera. Uma Visão Regional da História Paulista, editado por Carlos de A. P. Bacellar e Lucila R. Brioschi, 56-89. São Paulo: Humanitas, 1999.

Buarque de Holanda, Sérgio. "As colônias de parceria." In História Geral da Civilização Brasileira. II. O Brasil Monárquico: Reações e Transações, organizado por Sérgio Buarque de Holanda, 289-307. Rio de Janeiro: Bertand Brasil, 1987. 
Buarque de Holanda, Sérgio. "Prefácio do Tradutor." In Memórias de um colono no Brasil, por Thomas Davatz. São Paulo: Livraria Martins, 1941.

Camargo, José Francisco. Crescimento da população do Estado de São Paulo e seus aspectos econômicos. São Paulo: Instituto de Pesquisas Econômicas, 1981. 2v. (1952).

Cánovas, Marília D. K. “A emigração espanhola e a trajetória do imigrante na cafeicultura paulista: o caso de Villa Novaes, 1880-1930." Tese de Doutorado, FFLCH/USP, 2001.

Chiswick, Barry, e Timothy Hatton. "International Migration and the Integration of Labor Markets." IZA Discussion Papers n. 559 (2002).

Colistete, Renato Perim, e Maria Lucia Lamounier. "Land Inequality in a Coffee Economy: São Paulo During the Early Twentieth Century." Department Of Economics, FEA-USP. Working Paper Series 1 (2014).

Colistete, Renato. "Regiões e Especialização na Agricultura Cafeeira: São Paulo no Início do Século XX”. Revista Brasileira de Economia 69, n. 3 (jul./set. 2015): 331-354.

Collins, William, e Marianne H. Wanamaker. "Up from Slavery? African American Intergenerational Economic Mobility Since 1880." NBER Working Paper No. 23395 (May 2017).

Costa, Juan Solorzano y. El estado de São Paulo (Brasil). Estudio acerca de la verdadera situación del mismo en 1912-13. São Paulo: Talleres tipográficos del "Diario Español”, 1913.

Dantas, Humberto. "Imigração e População Estrangeira em São Paulo". Boletim do Serviço de Imigração e Colonização, n. 4 (dez. 1941): 101-16.

Davatz, Thomas. Memorias de um colono no Brasil (1850). São Paulo: Martins, 1951.

Dean, Warren. "Latifundia and Land Policy in Nineteenth-Century Brazil." The Hispanic American Historical Review 51, n. 4 (Nov. 1971): 606-65.

Dean, Warren. "A pequena propriedade dentro do complexo cafeeiro: Sitiantes no município de rio claro, 1870-1920.” Revista de História 53, n. 106 (1976): 187-94.

Dean, Warren. Rio Claro: um sistema brasileiro de grande fazenda (1820-1920). Rio de Janeiro: Ed. Paz e Terra, 1977.

Deffontaines, Pierre. "Pays et paysages de l'État de Saint-Paul (Brésil). Première esquisse de division régionale. (primier article)." Annales de Géographie, 45 (May 1936): 50-71.

Deffontaines, Pierre. "Pays et paysages de l'État de Saint-Paul (Brésil). Première esquisse de division régionale. (deuxième article)." Annales de Géographie, 45 (May 1936): 160-74.

Denis, Pierre. Brazil. Londres: T. Fisher Unwin, 1911.

Dias, Vanessa. "Inserção às avessas: a imigração espanhola em Franca-SP (19001955).” Dissertação de Mestrado, UNESP, 2010.

Ellis Jr., Alfredo. Populações Paulistas. São Paulo: ED. Nacional, 1934.

Engerman, Stanley L., e Kenneth L. Sokoloff. "Once Upon a Time in the Americas: Land and Immigration Policies in the New World." In Understanding Long-Run Economic Growth: Geography, Institutions, and the Knowledge Economy, editado 
por Dora L. Costa and Naomi R. Lamoreaux, 13-48. University of Chicago Press, 2008.

Fausto, Boris. Historiografia da imigração para São Paulo. São Paulo: Sumaré/FAPESP, 1991.

Feigenbaum, James. "Intergenerational Mobility during the Great Depression." Working Paper (2015).

Feigenbaum, James. "A Machine Learning Approach to Census Record Linking." Working Paper (March 28, 2016).

Feigenbaum, James. "Multiple Measures of Historical Intergenerational Mobility: Iowa 1915 to 1940.” Economic Journal 128, n. 612 (2018): 446-81.

Ferlini, Vera Lúcia e Elizabeth Fillipini. "Os Núcleos Coloniais Paulistas em Perspectiva Historiográfica.” Revista Brasileira de História 25 (1993): 147-66.

Ferreira, Luiz Mateus da Silva. "Terra, Trabalho e Indústria na Colônia de Imigrantes Dona Francisca (Joinville), Santa Catarina, 1850-1920". Tese de Doutorado, FFLCH/USP, 2019.

Ferrie, Joseph P., e Thimothy J. Hatton. "Two centuries of international migration." IZA Discussion Paper n. 7866 (Dec. 2013).

Font, Maurício. "Changing patterns in the Social Organization of the Coffee Export Sector in São Paulo, 1889-1930." Center for Research on Social Organization, University of Michigan Working Paper 268 (1982).

Forjaz, Djalma. O Senador Vergueiro: sua vida e sua época, 1778-1859. São Paulo: Diario Official, 1924.

Gadelha, Regina M. d'Aquino. "Os núcleos coloniais e o processo de acumulação cafeeira (1850-1920). Contribuição ao estudo da colonização em São Paulo.” Tese de Doutorado, FFLCH/USP, 1982.

Ghirardello, Nilson. À beira da linha: formações urbanas da Noroeste Paulista. São Paulo: Editora UNESP, 2001.

Gifun, Frederick V. "Ribeirão Preto, 1880-1914: The Rise of a Coffee County, or the Transition to Coffee in São Paulo as Seen Through the Development of Its Leading Producer.” Ph.D. diss., University of Florida, 1972.

Goeken, Ron, Lap Huynh, T. A. Lynch, and Rebecca Vick. "New Methods of Census Record Linking." Historical Methods 44, n. 1 (jan./mar. 2011): 7-14.

Gonçalves, Paulo C. "Mercadores de Braços. Riqueza e acumulação na organização da emigração europeia para o Novo Mundo.” Tese de Doutorado, FFLCH/USP, 2008.

Gonçalves, Paulo C. "A Hospedaria de Imigrantes de São Paulo: um novo espaço para o recrutamento de braços europeus pela economia cafeeira." In Brasil-Portugal. Pontes sobre o Atlântico: múltiplos olhares sobre a e/imigração, organizado por Lená Medeiros de Menezes e Fernando Sousa, 251-264. Rio de Janeiro: EdUERJ, 2017.

Gonçalves, Paulo C., Lélio Luiz de Oliveira e Pablo Oller Mont Serrath. "São Paulo e os sentidos da colonização." Revista História, Dossiê História da Colonização em Terras Paulistas: Dinâmicas e Transformações (Séculos XVI a XX) 39 (2020): 142.

Greffé, Louis Albert. Visions du Brésil. São Paulo: Francisco Alves e Cia, 1912. 
Grosselli, Renzo. Da schiavi Bianchi a coloni. Um progetto per la fazenda - Contadini trentini (veneti e Lombardi) nelle foreste brasiliane. Parte IV - São Paulo 18751914. Trento: Provincia Autonoma di Trento, 1991.

Hall, Michael. "Origins of mass migration in Brazil, 1871-1914." PhD Thesis, Columbia University, 1969.

Hall, Michael. "Reformadores de Classe Média no Império Brasileiro: A Sociedade Central de Imigração." Revista de História XXVII, v. LIII (1976): 147-71.

Hatton, Timothy J., e Jeffrey G. Williamson. "International Migration And World Development: A Historical Perspective." NBER Working Papers Series (1992).

Hatton, Timothy J., e Jeffrey G. Williamson. "What Drove the Mass Migrations from Europe in the Late Nineteenth Century?" Population and Development Review 20, n. 3 (Sep., 1994).

Hatton, Timothy J., e Jeffrey G. Williamson. The age of mass migration. New York: Oxford University Press, 1998.

Hatton, Timothy J., e Jeffrey G. Williamson. "What fundamentals drive world migration?” NBER Working Paper 9159 (2002).

Hatton, Timothy J., e Jeffrey G. Williamson. "International migration in the long-run: positive selection, negative selection and policy." NBER Working Paper 10529 (2004).

Heflinger Jr, José Eduardo. A revolta dos parceiros na Ibicaba. Limeira: Unigráfica, 2009.

Holloway, Thomas. "Migrations and mobility: immigrants as laborers and landowners in the coffee zone of São Paulo, Brazil, 1886-1934." PhD thesis, University of Wisconsin, 1974.

Holloway, Thomas. "The coffee colono of São Paulo, Brazil: migration and mobility, 1880-1930." In Land and Labour in Latin America, editado por Kenneth Duncan, Ian Rutledge and Colin Harding, 301-21. Cambridge University press, 1977.

Holloway, Thomas. Imigrantes para o café. São Paulo: Paz e Terra, 1984.

Hutter, Lucy Maffei. Imigração italiana em São Paulo (1880-1889): os primeiros contatos do imigrante com o Brasil. São Paulo: IEB, 1972.

Klein, Herbert. "A integração dos italianos no Brasil, na Argentina e Estados Unidos”, Novos Estudos CEBRAP 25 (out. 1989): 95-117.

Klein, Herbert. "A integração social e econômica dos portugueses no Brasil nos finais do século XIX e no século XX.” Análise Social 121, n. 2 (1993): 17-37.

Klein, Herbert. A imigração espanhola no Brasil. São Paulo: Ed. Sumaré, 1994.

Klein, Herbert. "European and Asian Migration to Brazil". In The Cambridge Survey of World Migration, edited by Robin Cohen, 208-14. Cambridge: Cambridge University Press, 1995.

Klein, Herbert. "Migração Internacional na História das Américas." In Fazer a América, org. Boris Fausto, 13-32. São Paulo: EDUSP, 2000.

Lamounier, Maria Lucia. "Between slavery and free labour: experiments with free labour and patterns of slave emancipation in Brazil and Cuba c.1830-1888". PhD thesis, The London School of Economics and Political Science (LSE), 1993.

Lamounier, Maria Lucia. "Ferrovias, agricultura de exportação e mão de obra no Brasil do século XIX.” Tese de Livre Docência, FEARP/USP, 2008. 
Lanza, André Luiz e Maria Lúcia Lamounier. "A América Latina como destino dos imigrantes: Brasil e Argentina (1870-1930).” Cadernos PROLAM/USP (Online) 14, n. 27 (2015): 90-107.

Lanza, André Luiz, e Maria Lúcia Lamounier. "O fluxo migratório entre São Paulo e Buenos Aires: deslocamentos, nacionalidades e motivações (1890-1930)." HIb: Revista de Historia Iberoamericana 10, n. 1 (2017): 34-58.

Lanza, André Luiz. "E 'fizeram américa'? Mobilidade socioeconômica dos primeiros colonos da Ibicaba." In Ibicaba, 200 anos: em comemoração ao colóquio do bicenentenário, eds., Leonardo Antonio Santin Gardenal e Bruno Gabriel Witzel De Souza (Cordeirópolis: Prefeitura Municipal, no prelo).

Leopoldino, Everton Altmayer, "O dialeto tretino da Colônia Tirolesa de Piracicaba: aspectos fonéticos e lexicais". Tese de doutorado, FFLCH/USP, 2014.

Levy, Maria Stella Ferreira. "O papel da migração internacional na evolução da população brasileira (1872-1972).” Revista de Saúde Pública 8 (1974): 49-90.

Lima, Angel Bernadete. “Nós declaramos guerra ao latifúndio!': Propostas, ações e ideais de imigração/colonização da Sociedade central de Immigração (1883-1891)." Dissertação de mestrado, UFSC, Florianópolis, 2015.

Lima, Rui Cirne. Pequena história territorial do Brasil: sesmarias e terras devolutas. Goiânia: Ed. UFG, 2002.

Long, Jason, e Joseph P. Ferrie. "Intergenerational occupational mobility in Great Britain and the United States since 1850." The American Economic Review 103 (2013): 1109-1137.

Luna, Francisco e Klein, Herbert. An Economic and Demographic History of São Paulo, 1850-1950. Stanford: Stanford University Press, 2018.

Luna, Francisco, Herbert Klein e William Summerhill. "A agricultura paulista em 1905." Estudos Econômicos 44, n. 1 (jan./mar. 2014): 153-84.

Maciel, Laura A. e Maria A. M. Antonacci, "Espanhóis em São Paulo: modos de vida e experiências de associação." Projeto História 12 (out. 1995): 173-92.

Marcondes, Renato L. "O Café em Ribeirão Preto (1890-1940)." História Econômica \& História de Empresas 10, n. 1 (2007): 171-92.

Marcondes, Renato L. "A estrutura fundiária e cafeeira de dois municípios do oeste paulista: Campinas e Ribeirão Preto no início do século XX." Revista de História 165 (jul./dez, 2011): 403-24.

Martinho Prado Júnior - in memoriam, por Martinho Prado Júnior. São Paulo, 1943.

Martins, José de Souza. “A imigração espanhola para o Brasil e a formação da força-detrabalho na economia cafeeira: 1880-1930.” Revista de História 121 (ago./dez. 1989): 5-26.

Martins, José de Souza. O cativeiro da terra, 9. ed. São Paulo: Contexto, 2010.

Matos, Maria Izilda Santos de e Sênia Bastos. "Portugueses em São Paulo. Registros e Ingressos (1912): Hospedaria do Imigrante - Listas de Bordo e Livros de Registro." In Nas duas margens. Os portugueses no Brasil, editado por Ismenia Martins e Maria Izilda Santos de Matos, 269-87. Porto: CEPESE/Afrontamento, 2009.

Mattos, Maria Izilda dos Santos e Oswaldo Truzzi. "Colonização e fronteiras: portugueses, presença, trabalho e lutas nos interiores de São Paulo". História 39, 
Dossiê História da Colonização em Terras Paulistas: Dinâmicas e Transformações (Séculos XVI a XX) (2020).

Mattos, Maria Izilda dos Santos, Oswaldo Truzzi e Carla F. Conceição. "Mulheres imigrantes: presença e ocultamento (interiores de São Paulo, 1880-1930)." Revista Brasileira de Estudos Populacionais 35, n. 3 (2018).

Melendez, José Juan Pérez. "Reconsiderando a política de colonização no Brasil Imperial: os anos da Regência e o mundo externo." Revista Brasileira de História 34, n. 68 (2014): 35-60.

Mesquita, Sergio Luiz Monteiro. "A Sociedade Central de Imigração e a Política Imigratória Brasileira (1883-1910)”. Dissertação de Mestrado, UERJ, 2000.

Milliet, Sergio. "A Mogiana e a Paulista". In Roteiros do café e outros ensaios, organizado por Sergio Milliet, 5-72. São Paulo: Coleção Departamento de Cultura, 1941.

Milliet, Sergio. "O desenvolvimento da pequena propriedade no estado de São Paulo (1939)". In Roteiros do café e outros ensaios, organizado por Sergio Milliet, 73121. São Paulo: Coleção Departamento de Cultura, 1941.

Milliet, Sergio. "Roteiros do café". In Roteiros do café e outros ensaios, organizado por Sergio Milliet, 5-72. São Paulo: Coleção Departamento de Cultura, 1941.

Monasterio, Leonardo. "Surnames and ancestry in Brazil", PLoS ONE.12, n. 5 (2017).

Monasterio, Leonardo e Daniel Lopes. "Brasil sem imigrantes: estimativas de longo prazo baseadas em microdados.” Texto para Discussão 2435 IPEA (nov. 2018).

Monbeig, Pierre. Pioneiros e fazendeiros de São Paulo. São Paulo: HUCITEC, 1984.

Motta, Marcia Maria. Nas fronteiras do poder. Rio de Janeiro: Vício de Leitura; Arquivo Público do Estado do Rio de Janeiro, 1998.

Mulhern, Joseph Martin. "After 1833: British Entanglement with Brazilian Slavery." Doctoral thesis, Durham University, 2018.

Murilo de Carvalho, José. Teatro das sombras: a política imperial. São Paulo: Vértice, 1988.

Nabuco, Joaquim, O Abolicionista. São Paulo: Publifolha, 2000.

Nabuco, Joaquim. Campanha abolicionista no Recife: eleições de 1884, discursos de Joaquim Nabuco. Rio de Janeiro: Typ. de G. Leuzinger \& Filhos, 1885.

Nascimento, Leonardo. "Trabalho e prestígio social: os espanhóis em São Paulo" In História econômica da Primeira República, organizado por Sergio Silva e Tamás Szmrecsányi. São Paulo: Edusp/Imprensa Oficial/Hucitec, 2002.

Paiva, Odair da Cruz, e Soraya Moura. Hospedaria de Imigrantes de São Paulo. São Paulo: Paz e Terra, 2004.

Paiva, Odair da Cruz. "Arquivos da Imigração no Contexto da Hospedaria de Imigrantes de São Paulo.” Patrimônio e Memória 5, n. 2 (dez. 2009): 82-97.

Pérez, Santiago. "Intergenerational Occupational Mobility across Three Continents." The Journal of Economic History 79 (Jun. 2019): 383-416.

Pérez, Santiago. "The (South) American Dream: Mobility and Economic Outcomes of First-and Second-Generation Immigrants in Nineteenth-Century Argentina". The Journal of Economic History 77 (2017): 971-1006.

Pestana, Paulo R. O café em São Paulo. São Paulo: Typographia Levi, 1927. 
Petri, Kátia Cristina, “"Mandem vir seus parentes': a Sociedade Promotora de Imigração em São Paulo (1886-1896)." Dissertação de Mestrado, PUC-SP, 2010.

Petrone, Maria Thereza Schorer. "Imigração." In O Brasil republicano. Sociedade e instituições (1889-1930), organizado por Boris Fausto, 95-133, v. 2. Rio de Janeiro: Bertrand Brasil, 1997.

Petrone, Maria Thereza Schorer. Imigrantes e a pequena propriedade. São Paulo: Brasiliense, 1982.

Pio di Savoia, Gherardo "Lo stato di San Paolo (Brasile) e l'emigrazione italiana" in Bolletino dell'emigrazione anno 1905, editado por Ministerio degli Affari Esteri. Roma: Tipografia nacionalide di G. Bertero, 1906.

Prado Jr, Caio. "Distribuição da propriedade fundiária rural no estado de São Paulo" [Publicado originalmente em Geografia, n. 1, v. 1, 1935]. Boletim Geográfico, n. 29 (out. 1945): 692-700.

Prado, Eduardo. "A imigração no Brasil." Boletim do Serviço de Imigração e Colonização 4 (dez. 1941): 111-3.

Prutsch, Ursula. A emigração de austríacos para o Brasil (1876-1938). Brasília: Embaixada Austríaca no Brasil, 2011.

Rapoport, Mário. Historia económica, política y social de la Argentina, 1880-2000. Buenos Aires: Editorial Macchi, 2000.

Rebouças, André. A democracia rural Brazileira. Rio de Janeiro, 1875.

Rebouças, André. Agricultura Nacional: estudos economicos: propaganda abolicionista e democratica, setembro de 1874 a setembro de 1883. Rio de Janeiro: A. J. Lamoureux, 1883.

Retsö, Dag. "Emigration from the Nordic countries to Brazil 1880-1914." Iberoamericana - Nordic Journal of Latin American and Caribbean Studies 45, n. 1 (2016): 6-18.

Ricciardi, Adelino R. "Parnaíba, o pioneiro da imigração." Revista do Arquivo Municipal XLIV (fev. 1938).

Rocha, Rudi, Claudio Ferraz e Rodrigo Soares. "Human Capital Persistence and Development." American Economic Journal: Applied Economics 9, n. 4 (2017): 105-36.

Salisbury, Laura. "Selective migration, wages, and occupational mobility in nineteenth century America." Explorations in Economic History 53 (2014): 40-63.

Sanches, Almir Teubl. "A questão de terras no início da República: o Registro Torrens e sua (in)aplicação.” Dissertação de Mestrado, FDUSP, 2008.

Sánchez-Alonso, Blanca. "Those Who Left and Those Who Stayed behind: Explaining Emigration from the Regions of Spain, 1880-1914." The Journal of Economic History 60, n. 3 (Sep. 2000): 730-755.

Silva, João Paulo da. "Espanhóis no interior de São Paulo: múltiplas possibilidades de incorporação". Tese de doutorado, UFSCAR, 2020.

Silva, Ligia Osório. Terras devolutas e latifúndio: efeitos da lei de 1850. Campinas: Editora da UNICAMP, 1996.

Stolcke, Verena e Michael Hall. "A introdução do trabalho livre nas fazendas de café de São Paulo." Revista Brasileira de História. 6 (set. 1983): 80-120. 
Stolcke, Verena. Cafeicultura. Homens, Mulheres e Capital (1850-1980). São Paulo: Editora Brasiliense, 1986.

Tavares Bastos, Aureliano C. Os Males do Presente e as Esperanças do Futuro. São Paulo: Cia Editora Nacional, 1939.

Tosi, Pedro Geraldo; Rogério Naques Faleiros e Rodrigo da Silva Teodoro. "Fragmentos de um modelo: pequenas fazendas de café e acumulação de capitais. Franca/São Paulo 1890-1914." História 24, n. 2 (2005): 291-327.

Trochim, Michael Robert. "Retreat from Reform: The fall of the Brazilian Empire 18881889." PhD diss., University of Illinois, 1983.

Truzzi, Oswaldo e João Pedro Volante. "Percursos migratórios intergeracionais e dinâmicas de implantação de imigrantes estrangeiros no oeste paulista (18801950)." Tempo Social 31, n. 3 (2019): 161-191.

Truzzi, Oswaldo. "Café e indústria no interior de São Paulo (o caso de São Carlos)." Dissertação de Mestrado, EAESP/FGV, 1985.

Truzzi, Oswaldo. "Percursos e descaminhos da italianidade no interior paulista," in Anais do $37^{\circ}$ Encontro Anual da ANPOCS. Águas de Lindóia, set. 2013.

Udaeta, Rosa Guadalupe Soares. "Nem Brás, nem Flores: Hospedaria de imigrantes da cidade de São Paulo (1875-1886).” Dissertação de Mestrado, FFLCH/USP, 2016.

Vangelista, Chiara. Os braços da lavoura. São Paulo: Hucitec, 1991.

Viotti da Costa, Emília. Da monarquia à república: momentos decisivos. São Paulo: Fundação Editora da UNESP, 1999.

Wegge, Simone A. "Chain Migration and Information Networks: Evidence from Nineteenth-Century Hesse-Cassel." The Journal of Economic History 58, n. 4 (Dec., 1998): 957-86.

Wegge, Simone A. "Occupational Self-selection of European Emigrants: Evidence from Nineteenth-Century Hesse-Cassel", European Review of Economic History 6, n. 3 (2002): 365-94.

Witzel de Souza, Bruno Gabriel. "From Bonded Laborers to Educated Citizens? Immigration, Labor Markets, and Human Capital in São Paulo, Brazil (18202010)." PhD diss, Georg-August-Universität Göttingen, 2019.

Witzel de Souza, Bruno Gabriel. "Imigração alemã e mercado de trabalho na cafeicultura paulista: um estudo quantitativo dos contratos de parceria." História Econômica \& História de Empresas 15, n. 2 (jul./dez. 2012): 81-109. 


\section{ANEXOS}

Anexo A1.1 - Núcleos coloniais existentes em São Paulo entre 1911 e 1918: população e produção

\begin{tabular}{|c|c|c|c|c|c|c|c|c|}
\hline & Ano & Extensão cultivada & Nacionais & Estrangeiros & Total & Agrícola & Extrativa e zootécnica & Total \\
\hline \multirow{8}{*}{ Bandeirantes } & 1911 & 377,7 & 207 & 234 & 441 & $21: 129 \$ 000$ & & $21: 129 \$ 000$ \\
\hline & 1912 & 412,12 & 539 & 365 & 904 & $50: 976 \$ 100$ & 1:000\$000 & $52: 036 \$ 000$ \\
\hline & 1913 & 520,64 & 597 & 443 & 1040 & $78: 824 \$ 250$ & $20: 575 \$ 400$ & $99: 299 \$ 650$ \\
\hline & 1914 & 763,92 & 719 & 395 & 1114 & $124: 146 \$ 550$ & $32: 338 \$ 200$ & $156: 484 \$ 750$ \\
\hline & 1915 & 754,59 & 889 & 400 & 1289 & $128: 802 \$ 500$ & $39: 795 \$ 000$ & $168: 597 \$ 500$ \\
\hline & 1916 & 717,32 & 922 & 358 & 1280 & $145: 086 \$ 550$ & $45: 912 \$ 000$ & $189: 998 \$ 550$ \\
\hline & 1917 & 816,83 & 938 & 313 & 1251 & $156: 274 \$ 710$ & $56: 929 \$ 000$ & $213: 308 \$ 700$ \\
\hline & 1918 & 886 & 1015 & 328 & 1343 & $215: 922 \$ 400$ & $66: 208 \$ 500$ & $282: 180 \$ 900$ \\
\hline \multirow{8}{*}{$\begin{array}{l}\text { Conde de } \\
\text { Parnahyba }\end{array}$} & 1911 & & & & 0 & & & \\
\hline & 1912 & 791 & 722 & 243 & 965 & $61: 983 \$ 000$ & $113: 702 \$ 000$ & $175: 685 \$ 000$ \\
\hline & 1913 & 791 & 722 & 243 & 965 & $145: 787 \$ 500$ & $97: 990 \$ 000$ & $243: 777 \$ 500$ \\
\hline & 1914 & 1021 & 847 & 290 & 1137 & $187: 739 \$ 900$ & $198: 154 \$ 000$ & $385: 893 \$ 900$ \\
\hline & 1915 & 1323 & 1029 & 816 & 1845 & $270: 441 \$ 000$ & $231: 442 \$ 500$ & $501: 883 \$ 500$ \\
\hline & 1916 & - & 1141 & 407 & 1548 & 489:612\$500 & $281: 788 \$ 000$ & $771: 400 \$ 500$ \\
\hline & 1917 & - & 1319 & 405 & 1724 & $1126: 552 \$ 710$ & $676: 560 \$ 000$ & $1803: 112 \$ 700$ \\
\hline & 1918 & - & 1514 & 394 & 1908 & $606: 631 \$ 677$ & $420: 253 \$ 000$ & $1026: 884 \$ 677$ \\
\hline \multirow{8}{*}{ Gavião Peixoto } & 1911 & 372 & 271 & 649 & 920 & $133: 350 \$ 000$ & $47: 634 \$ 000$ & $180: 984 \$ 000$ \\
\hline & 1912 & 1350 & 952 & 496 & 1448 & $145: 421 \$ 000$ & $3: 800 \$ 000$ & $149: 221 \$ 000$ \\
\hline & 1913 & 1350 & 1040 & 551 & 1591 & $194: 049 \$ 200$ & $7: 920 \$ 000$ & $201: 969 \$ 200$ \\
\hline & 1914 & 2887 & 1372 & 554 & 1926 & $137: 154 \$ 900$ & $63: 817 \$ 000$ & 200:971\$900 \\
\hline & 1915 & 3026 & 1296 & 816 & 2112 & $416: 639 \$ 300$ & $156: 968 \$ 000$ & $573: 607 \$ 300$ \\
\hline & 1916 & 3140 & 1396 & 930 & 2326 & 959:089\$000 & $258: 587 \$ 200$ & $1216: 626 \$ 200$ \\
\hline & 1917 & 3434 & 1552 & 976 & 2528 & $1171: 468 \$ 400$ & $889: 110 \$ 000$ & $1560: 578 \$ 400$ \\
\hline & 1918 & 3996 & 1612 & 1016 & 2628 & 1527:639\$800 & $226: 896 \$ 000$ & $1754: 035 \$ 800$ \\
\hline Jorge Tybirica & 1911 & 183,92 & 234 & 858 & 1092 & $219: 223 \$ 000$ & $130: 460 \$ 000$ & $349: 683 \$ 000$ \\
\hline
\end{tabular}




\begin{tabular}{|c|c|c|c|c|c|c|c|c|}
\hline & 1912 & 810,46 & 256 & 970 & 1226 & & & \\
\hline & 1913 & 1437 & - & - & & $271: 765 \$ 000$ & $158: 435 \$ 200$ & $430: 200 \$ 200$ \\
\hline & 1914 & 1664,5 & 472 & 900 & 1372 & $315: 860 \$ 000$ & $36: 108 \$ 500$ & $351: 968 \$ 500$ \\
\hline & 1915 & 1892 & 1401 & 686 & 2087 & $63: 533 \$ 400$ & $7: 900 \$ 000$ & $71: 433 \$ 400$ \\
\hline & 1916 & 1892 & 1457 & 730 & 2187 & 1099:415\$000 & $53: 343 \$ 000$ & $1252: 758 \$ 000$ \\
\hline & 1917 & 1892 & 1537 & 770 & 2307 & 1563:960\$000 & $158: 950 \$ 000$ & $1722: 910 \$ 000$ \\
\hline & 1918 & 1892 & 1956 & 891 & 2847 & $912: 300 \$ 000$ & $294: 634 \$ 000$ & $1206: 934 \$ 000$ \\
\hline \multirow{8}{*}{$\begin{array}{l}\text { Martinho Prado } \\
\text { Junior }\end{array}$} & 1911 & - & - & - & & - & - & \\
\hline & 1912 & 50 & 98 & 86 & 184 & $6: 445 \$ 000$ & & $6: 445 \$ 000$ \\
\hline & 1913 & 137,94 & 280 & 42 & 322 & $45: 016 \$ 000$ & $1: 113 \$ 000$ & $46: 129 \$ 000$ \\
\hline & 1914 & 104,86 & 186 & 70 & 256 & $47: 033 \$ 500$ & $1: 882 \$ 000$ & $49: 013 \$ 500$ \\
\hline & 1915 & 108,9 & 188 & 70 & 258 & $8: 530 \$ 000$ & $1: 580 \$ 000$ & $10: 110 \$ 000$ \\
\hline & 1916 & 219,22 & 185 & 85 & 270 & $20: 027 \$ 500$ & $16: 385 \$ 000$ & $86: 112 \$ 500$ \\
\hline & 1917 & 206,91 & 205 & 83 & 288 & $36: 070 \$ 900$ & $81: 441 \$ 289$ & $67: 512 \$ 189$ \\
\hline & 1918 & 3528 & 311 & 32 & 343 & $45: 737 \$ 000$ & $86: 827 \$ 500$ & $182: 564 \$ 000$ \\
\hline \multirow{8}{*}{ Monção } & 1911 & & & & 0 & & & \\
\hline & 1912 & 566,06 & 188 & 769 & 957 & $20: 724 \$ 000$ & $4: 620 \$ 000$ & $25: 344 \$ 000$ \\
\hline & 1913 & 1321 & 591 & 1074 & 1665 & $108: 683 \$ 000$ & $6: 860 \$ 000$ & $115: 543 \$ 000$ \\
\hline & 1914 & 2016,58 & 754 & 1174 & 1928 & $151: 745 \$ 000$ & 39:925\$000 & 191:070\$000 \\
\hline & 1915 & 3310 & 1035 & 1434 & 2469 & $325: 705 \$ 000$ & $26: 627 \$ 000$ & $352: 332 \$ 000$ \\
\hline & 1916 & 219,22 & 966 & 1375 & 2341 & $20: 027 \$ 500$ & $16: 385 \$ 000$ & $36: 412 \$ 189$ \\
\hline & 1917 & 206,91 & 1169 & 1674 & 2843 & $36: 070 \$ 000$ & $31: 441 \$ 289$ & $67: 512 \$ 189$ \\
\hline & 1918 & 3528 & 1387 & 1827 & 3214 & $45: 737 \$ 000$ & $86: 827 \$ 500$ & $132: 564 \$ 300$ \\
\hline \multirow{7}{*}{ Nova Europa } & 1911 & 1750 & 103 & 1328 & 1431 & $133: 780 \$ 000$ & $65: 825 \$ 500$ & $199: 605 \$ 500$ \\
\hline & 1912 & 2037 & 293 & 1458 & 1751 & $235: 820 \$ 000$ & $7: 390 \$ 000$ & $243: 210 \$ 000$ \\
\hline & 1913 & 2115 & 844 & 1069 & 1913 & $216: 107 \$ 000$ & $7: 573 \$ 000$ & $233: 680 \$ 000$ \\
\hline & 1914 & 2740 & 854 & 1111 & 1965 & $123: 230 \$ 000$ & $28: 400 \$ 000$ & $154: 630 \$ 000$ \\
\hline & 1915 & 2902 & 936 & 1170 & 2106 & $170: 950 \$ 000$ & 38:960\$000 & 209:910\$000 \\
\hline & 1916 & 2962,08 & 1058 & 1319 & 2377 & $418: 170 \$ 000$ & $207: 700 \$ 000$ & $625: 870 \$ 600$ \\
\hline & 1917 & 3455 & 1168 & 1365 & 2533 & $667: 580 \$ 000$ & $233: 620 \$ 000$ & $901: 200 \$ 000$ \\
\hline
\end{tabular}




\begin{tabular}{|c|c|c|c|c|c|c|c|c|}
\hline & 1918 & - & 1334 & 1443 & 2777 & $832: 500 \$ 000$ & $37: 490 \$ 000$ & $869: 990 \$ 000$ \\
\hline \multirow{8}{*}{ Nova Odessa } & 1911 & 1469 & 87 & 848 & 935 & $20: 954 \$ 000$ & 20:999\$500 & $41: 953 \$ 500$ \\
\hline & 1912 & 1649 & & & 0 & $125: 121 \$ 000$ & & $125: 121 \$ 000$ \\
\hline & 1913 & 1282 & 506 & 471 & 977 & $127: 182 \$ 000$ & $58: 539 \$ 500$ & $186: 021 \$ 500$ \\
\hline & 1914 & 1570 & 678 & 510 & 1188 & $116: 084 \$ 000$ & $29: 600 \$ 000$ & $145: 684 \$ 000$ \\
\hline & 1915 & 1361 & 726 & 527 & 1253 & $203: 253 \$ 000$ & $65: 505 \$ 600$ & $268: 758 \$ 000$ \\
\hline & 1916 & 1301 & 780 & 521 & 1301 & $217: 510 \$ 000$ & $70: 923 \$ 000$ & $288: 433 \$ 000$ \\
\hline & 1917 & - & - & - & & $244: 790 \$ 180$ & $55: 480 \$ 000$ & $300: 270 \$ 180$ \\
\hline & 1918 & - & - & - & & - & - & - \\
\hline \multirow{8}{*}{ Nova Veneza } & 1911 & 478 & 16 & 272 & 288 & $15: 115 \$ 000$ & $13: 279 \$ 000$ & $28: 394 \$ 000$ \\
\hline & 1912 & 625 & 67 & 407 & 474 & $28: 300 \$ 000$ & $46: 557 \$ 000$ & $74: 857 \$ 000$ \\
\hline & 1913 & 750 & 115 & 449 & 564 & $84: 331 \$ 000$ & $8: 900 \$ 000$ & $93: 231 \$ 000$ \\
\hline & 1914 & 980 & 123 & 488 & 611 & $71: 845 \$ 000$ & $33: 679 \$ 000$ & $83: 459 \$ 000$ \\
\hline & 1915 & 1125 & 131 & 518 & 649 & $94: 050 \$ 000$ & $11: 474 \$ 000$ & $105: 524 \$ 000$ \\
\hline & 1916 & 1185 & 86 & 576 & 662 & 232:051\$500 & $8: 835 \$ 000$ & $240: 886 \$ 500$ \\
\hline & 1917 & 1828 & 101 & 597 & 698 & $256: 127 \$ 900$ & $20: 810 \$ 500$ & $276: 938 \$ 400$ \\
\hline & 1918 & 2110 & 93 & 631 & 724 & $211: 602 \$ 950$ & $32: 966 \$ 000$ & $244: 568 \$ 950$ \\
\hline \multirow{8}{*}{ Pariquera Assu } & 1911 & 2129 & 1413 & 937 & 2350 & $226: 175 \$ 140$ & $72: 744 \$ 000$ & $298: 919 \$ 140$ \\
\hline & 1912 & 2153 & 1563 & 1043 & 2606 & $225: 700 \$ 950$ & $34: 492 \$ 000$ & $260: 192 \$ 000$ \\
\hline & 1913 & 2184 & 1650 & 1049 & 2699 & 231:017\$000 & $85: 755 \$ 500$ & $316: 772 \$ 500$ \\
\hline & 1914 & 2250 & 1731 & 1093 & 2824 & $220: 127 \$ 000$ & $82: 146 \$ 000$ & $302: 273 \$ 000$ \\
\hline & 1915 & 4101 & 1805 & 1087 & 2892 & 253:025\$000 & 63:998\$000 & $317: 023 \$ 000$ \\
\hline & 1916 & 4101 & 1834 & 1037 & 2871 & $252: 170 \$ 000$ & 202:050\$000 & $454: 220 \$ 000$ \\
\hline & 1917 & 4263 & 1892 & 1027 & 2919 & $303: 392 \$ 300$ & $247: 654 \$ 000$ & $551: 046 \$ 390$ \\
\hline & 1918 & 7084 & 2003 & 973 & 2976 & $422: 184 \$ 000$ & $102: 864 \$ 000$ & $525: 048 \$ 000$ \\
\hline \multirow{5}{*}{$\begin{array}{l}\text { Visconde de } \\
\text { Indaiatuba }\end{array}$} & 1911 & & & & 0 & & & \\
\hline & 1912 & & & & 0 & & & \\
\hline & 1913 & 387 & 517 & 116 & 633 & $7: 580 \$ 000$ & $241: 935 \$ 200$ & $249: 515 \$ 200$ \\
\hline & 1914 & 472 & 732 & 204 & 936 & $77: 479 \$ 000$ & $423: 588 \$ 000$ & $501: 067 \$ 000$ \\
\hline & 1915 & 560 & 923 & 243 & 1166 & $81: 867 \$ 000$ & $59: 970 \$ 000$ & $141: 887 \$ 000$ \\
\hline
\end{tabular}




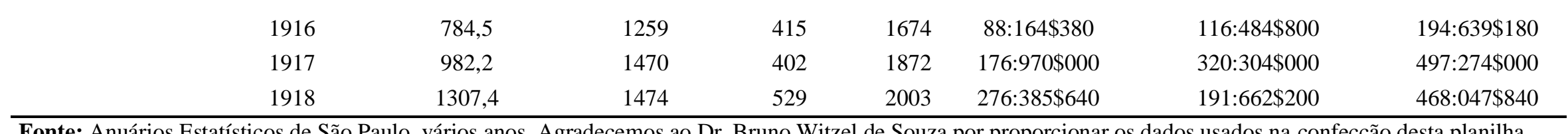

Fonte: Anuários Estatísticos de São Paulo, vários anos. Agradecemos ao Dr. Bruno Witzel de Souza por proporcionar os dados usados na confecção desta planilha. 
Anexo A2.1 - Mapeamento dos municípios do estado de São Paulo e seus desmembramentos entre 1905 e 1920

\begin{tabular}{|c|c|c|c|}
\hline Região & 1905 & 1920 & \\
\hline Alta Sorocabana & Agudos (1899) & Agudos & \\
\hline Mogiana & Amparo (1865) & Amparo & \\
\hline Paulista & Annapolis (1897) & Anápolis (Analândia) & \\
\hline Sorocaba & $\begin{array}{l}\text { Espirito Santo da Boa Vista } \\
\qquad(1906)\end{array}$ & Angatuba & \\
\hline Alta Sorocabana & $\begin{array}{l}\text { Remedos da Ponte do Tiete } \\
\qquad(1891)\end{array}$ & Anhembi & \\
\hline Baixa Sorocabana & & Apiaí & \\
\hline Baixa Sorocabana & Aplar (17/7) & Ribeira (1910) & \\
\hline Sorocaba & Araçariguama (1874) & Araçariguama & \\
\hline Paulista & Araraquara (1832) & Araraquara & \\
\hline Paulista & Araras (1879) & Araras & \\
\hline $\begin{array}{l}\text { Vale do Paraíba e } \\
\text { Litoral Norte }\end{array}$ & Areas (1857) & Areias & \\
\hline Central & Atibaia (1864) & Atibaia & \\
\hline $\begin{array}{l}\text { Alta Sorocabana } \\
\text { Alta Sorocabana }\end{array}$ & Avaré (1875) & $\begin{array}{c}\text { Avaré } \\
\text { Cerqueira Cesar (1917) }\end{array}$ & \\
\hline $\begin{array}{l}\text { Vale do Paraíba e } \\
\text { Litoral Norte }\end{array}$ & Bananal (1832) & Bananal & \\
\hline Araraquarense & Bariry (1890) & Bariri & \\
\hline $\begin{array}{l}\text { Paulista } \\
\text { Paulista }\end{array}$ & Barretos (1885) & $\begin{array}{c}\text { Barretos } \\
\text { Olimpia (1917) }\end{array}$ & \\
\hline Mogiana & & Batatais & \\
\hline Mogiana & Batataes (1839) & Altinópolis (1918) & \\
\hline Mogiana & & Brodósqui (1913) & \\
\hline Noroeste & & Bauru & \\
\hline $\begin{array}{l}\text { Noroeste } \\
\text { Noroeste }\end{array}$ & Bauru (1887) & $\begin{array}{c}\text { Avaí (1919) } \\
\text { Penápolis (1913) }\end{array}$ & \\
\hline Noroeste & & Pirajuí (1914) & Lins (1919) \\
\hline Paulista & & Bebedouro & \\
\hline Paulista & Bebedouro (1894) & $\begin{array}{l}\text { Monte Azul Paulista } \\
\text { (1914) }\end{array}$ & \\
\hline Araraquarense & Boa Esperança (1898) & Boa Esperança do Sul & \\
\hline Araraquarense & Bocaina (1891) & Bocaina & \\
\hline
\end{tabular}




Araraquarense
Alta Sorocabana
Central
Araraquarense
Vale do Paraíba e
Litoral Norte
Central
Vale do Paraíba e
Litoral Norte
Vale do Paraíba e
Litoral Norte
Mogiana
Mogiana
Central

Sorocaba

Alta Sorocabana

Alta Sorocabana

Alta Sorocabana

Santos e Litoral Sul

Baixa Sorocabana

$$
\begin{aligned}
& \text { Capital } \\
& \text { Central }
\end{aligned}
$$

Vale do Paraíba e

Litoral Norte

Mogiana

Alta Sorocabana

$$
\text { Capital }
$$$$
\text { Mogiana }
$$

Vale do Paraíba e

Litoral Norte

Vale do Paraíba e

Litoral Norte
Bom Sucesso

Botucatu (1855)

Braganca (1797)

Brotas (1859)

Buquira (1890)

Cabreúva(1859)

Caçapava (1855)

Santo Antonio da Bocaina

(Cachoeira Paulista) (1880)

Caconde (1864)

Cajuru (1865)

Campinas (1797)

Campo Largo de Sorocaba (1857)

Campos Novos do

Paranapanema (1885)

Cananea (1600)

Capão Bonito do

Paranapanema (1857)

São Paulo (1558)

Capivary (1832)

Caraguatatuba (1857)

Casa Branca (1841)

Cutia (1856)

Cravinhos (1897)

Cruzeiro (1871)

Cunha (1785)
Bom Sucesso

Botucatu

Bragança Paulista

Brotas

Buquira (Monteiro

Lobato)

Cabreúva

Caçapava

Cachoeira Paulista

Caconde

Cajuru

Campinas

Campo largo de

Sorocaba (Araçoiaba da

$$
\text { Serra) }
$$

Campos Novos Paulista

Platina (1915)

Assis (1917)

Palmital (1919)

Cananeia

Capão Bonito

São Paulo

Capivari

Caraguatatuba

Casa Branca

Conceição de Monte

Alegre

Cotia

Cravinhos

Cruzeiro

Cunha 
Paulista

Araraquarense

Araraquarense

Baixa Sorocabana

Mogiana

Alta Sorocabana

Alta Sorocabana

Mogiana

Vale do Paraíba e

Litoral Norte

Vale do Paraíba e

Litoral Norte

Sorocaba

Capital

Araraquarense

Mogiana

Vale do Paraíba e

Litoral Norte

Santos e Litoral Sul

Vale do Paraíba e

Litoral Norte

Central

Baixa Sorocabana

Baixa Sorocabana

Baixa Sorocabana

Santos e Litoral Sul

Capital

Sorocaba

Mogiana

Araraquarense

Araraquarense

Araraquarense

Baixa Sorocabana
Descalvado (1865)

Dous Córregos (1874)

Dourado (1897)

Xiririca (1842)

Espirito Santo do Pinhal

(1877)

Espirito Santo do Turvo

(1885)

Fartura (1891)

Franca (1821)

Guararema (1898)

Guaratinguetá (1844)

Guarehy (1880)

Guarulhos (1880)

Ibitinga (1890)

Santa Rita do Paraizó(1873)

Patrocínio de Santa Izabel

Iguape (1638)

Villa Bella (1805)

Indaiatuba(1859)

Iporanga (1873)

Lavinhas (1891)

Santo Antonio da Boa Vista

$$
\text { (1891) }
$$

Itanhaen (1561)

Itapecerica (1877)

Itapetininga (1771)

Itapira (1858)

Boa vista das Pedras (Itápolis)

Itararé (1893)
Descalvado

Dois Córregos

Dourado

Eldorado

Espirito Santo do

Pinhal

Espirito Santo do Turvo

Fartura

Franca

Guararema

Guaratinguetá

Guarei

Guarulhos

Ibitinga

Igarapava

Igaratá

Iguape

Ilhabela

Indaiatuba

Iporanga

Itaberá

Itaí

Itanhaém

Itapecerica da Serra

Itapetininga

Itapira

Itápolis

Novo Horizonte (1916)

Itajobi (1918)

Itararé 


\begin{tabular}{|c|c|c|}
\hline Central & Itatiba (1857) & Itatiba \\
\hline Alta Sorocabana & Itatinga (1896) & Itatinga \\
\hline Central & Itu (1657) & Itu \\
\hline Baixa Sorocabana & Faxina (1769) & Itapeva \\
\hline Baixa Sorocabana & Itaporanga (1871) & Itaporanga \\
\hline Mogiana & Ituverava $\left(1885_{-}\right.$ & Ituverava \\
\hline Paulista & & Jaboticabal \\
\hline Paulista & Jaboticabal (1867) & Guariba (1917) \\
\hline Paulista & & Piratininga (1913) \\
\hline $\begin{array}{c}\text { Vale do Paraíba e } \\
\text { Litoral Norte }\end{array}$ & Jacarehy (1653) & Jacareí \\
\hline Araraquarense & & Jau \\
\hline Araraquarense & Jahu (1866) & Barra Bonita (1912) \\
\hline Araraquarense & गанй $(1000)$ & $\begin{array}{c}\text { Bica de Pedra (Itapuí) } \\
\text { (1913) }\end{array}$ \\
\hline $\begin{array}{c}\text { Vale do Paraíba e } \\
\text { Litoral Norte }\end{array}$ & Jambeiro (1876) & Jambeiro \\
\hline Mogiana & Jardinópolis (1898) & Jardinópolis \\
\hline $\begin{array}{c}\text { Vale do Paraíba e } \\
\text { Litoral Norte }\end{array}$ & Jatahy & Jatai \\
\hline Central & $\begin{array}{c}\text { São João do Curralinho } \\
\text { (1895) }\end{array}$ & Joanópolis \\
\hline Central & Jundiaí (1655) & Jundiai \\
\hline $\begin{array}{c}\text { Vale do Paraíba e } \\
\text { Litoral Norte }\end{array}$ & Lagoinha $* 1880)$ & Lagoinha \\
\hline Paulista & Leme(1895) & Leme \\
\hline Alta Sorocabana & Lenções (1865) & Lençóis Paulista \\
\hline Paulista & Limeira (1842) & Limeira \\
\hline $\begin{array}{c}\text { Vale do Paraíba e } \\
\text { Litoral Norte }\end{array}$ & Lorena (1788) & Lorena \\
\hline Araraquarense & Mattao (1898) & Matão \\
\hline Araraquarense & Mineiros (1899) & Mineiros do Tiete \\
\hline Mogiana & Mococa (1871) & Mococa \\
\hline Mogiana & Mogy Mirim (1769) & Mogi-Mirim \\
\hline $\begin{array}{c}\text { Vale do Paraíba e } \\
\text { Litoral Norte }\end{array}$ & Mogy das Cruzes (1611) & Mogi das Cruzes \\
\hline
\end{tabular}


Mogiana

Capital

Araraquarense

Araraquarense

Araraquarense

Central

Vale do Paraíba e

Litoral Norte

Central

Mogiana

Mogiana

Vale do Paraíba e

Litoral Norte

Sorocaba

Mogiana

Araraquarense

Mogiana

Alta Sorocabana

Sorocaba

Sorocaba

Vale do Paraíba e

Litoral Norte

Vale do Paraíba e

Litoral Norte

Vale do Paraíba e

Litoral Norte

Central

Central

Alta Sorocabana

Paulista

Paulista

Paulista

Central

Paulista
Mogy guassu (1877)

Juqueri (Mairiporã) (1899)

Monte Alto (1896)

Monte Mor

Natividade

Nazareth

Nuporanga (1885)

Parahybuna (1857)

Parnahyba (1625)

Patrocínio do Sapucahy

(1885)

Pederneiras (1891)

Pedreira (1896)

Pereiras (1889)

Piedade (1857)

Pilar (1891)

Pindamonhangaba (1705)

Pinheiros (1881)

Vieira do Piquete (1891)

Piracaia (1859)

Piracicaba(1821)

Piraju (1880)

Pirassununga (1865)

Pitangueiras (1893)

Porto Feliz (1797)

Porto Ferreira (1896)
Mogi-Guaçu

Mairiporã

Monte Alto

Ariranha (1918)

Tabapuã (1919)

Monte Mor

Natividade da Serra

Nazaré Paulista

Orlândia

São Joaquim da Barra

(1917)

Paraibuna

Santana de Parnaíba

Patrocínio Paulista

Pederneiras

Pedreira

Pereiras

Piedade

Pilar do Sul

Pindamonhangaba

Pinheiros (Lavrinha)

Piquete

Piracaia

Piracicaba

Piraju

Pirassununga

Pitangueiras

Viradouro (1906)

Porto Feliz

Porto Ferreira 
Vale do Paraíba e

Litoral Norte

Vale do Paraíba e

Litoral Norte

Araraquarense

Baixa Sorocabana

Mogiana

Alta Sorocabana

Paulista

Central

Central

Alta Sorocabana

Central

Vale do Paraíba e

Litoral Norte

Paulista

Paulista

Alta Sorocabana

Alta Sorocabana

Alta Sorocabana

Alta Sorocabana

Vale do Paraíba e

Litoral Norte

Paulista

$$
\text { Capital }
$$

Mogiana

Santos e Litoral Sul
Queluz (1842)

Queluz

Redenção (1877)

Ribeirão Bonito (1890)

Ribeirão Branco (1892)

Ribeirão Preto (1871)

Rio Bonito (Bofete) (1880)

Rio Claro (1845)

Rio das Pedras (1894)

Salinópolis (1857)

Salto de Itu (1889)

Santa Bárbara do Rio Parto

(Águas de Santa Barbara)

(1876)

Santa Barbara (1869)

Santa Branca (1856)

Santa Cruz da Conceição

(1898)

Santa Cruz da das Palmeiras

(1885)

Palmeiras

Santa Cruz do Rio

Pardo

Santa Cruz do Rio

Pardo(1876)

Óleo (1917)

Salto Grande (1906)

Ourinhos

(1918)

Ipaussu (1915)

Santa Izabel (1832)

Santa Rita do Passa Quatro

(1885)

Santo Amaro (1832)

Santo Antônio d'Alegria

(1885)

Santos (1544)
Santa Isabel

Santa Rita do Passa

Quatro

Santo Amaro

Santo Antônio da

Alegria

Santos 
Vale do Paraíba e

Litoral Norte

Capital

Paulista

Mogiana

Vale do Paraíba e

Litoral Norte

Mogiana

Araraquarense

Araraquarense

Vale do Paraíba e

Litoral Norte

Vale do Paraíba e

Litoral Norte

Alta Sorocabana

Baixa Sorocabana

Central

Alta Sorocabana

Sorocaba

Vale do Paraíba e

Litoral Norte

Mogiana

Mogiana

Santos e Litoral Sul

Sorocaba

Mogiana

Mogiana

Vale do Paraíba e

Litoral Norte

Mogiana

Sorocaba

Mogiana

Araraquarense

Araraquarense
São Bento do Sapucahy

(1858)

São Bernardo (1889)

São Carlos (1865)

São Joao da Boa Vista (1859) São Joao da Boa Vista

São José do Barreiro (1859)

São Jose do Rio Pardo (1885)

São José do Rio Preto (1894)

São Jose dos Campos (1767) São Jose dos Campos

São Luiz do Paratinga (1773) São Luis do Paraitinga

São Manoel (1885)

São Miguel Archanjo (1889)

São Pedro(1881)

São Pedro do Turvo (1891)

São Roque (1832)

São Sebastiao (1875)

São Simão (1865)

São Vicente (1852)

Sarapuhy (1872)

Serra Negra (1859)

Sertãozinho (1896)

Silveiras (1842)

Socorro (1871)

Sorocaba (1661)

Tambahu (1892)

Ribeirãozinho (Taquaritinga)

(1892)
São Bento do Sapucaí

São Bernardo do

Campo

São Carlos

São Jose do Barreiro

São Jose do Rio Pardo

São Jose do Rio Preto

Catanduva (1917)

São Manuel

São Miguel Archanjo

São Pedro

São Pedro do Turvo

São Roque

São Sebastiao

São Simão

Santa Rosa do Viterbo

(1906)

São Vicente

Sarapui

Serra Negra

Sertãozinho

Silveiras

Socorro

Sorocaba

Tambaú

Taquaritinga

Santa Adélia (1916) 


$\begin{array}{ccc}\text { Sorocaba } & \text { Tatuhy(1844) } & \text { Tatuí } \\ \text { Vale do Paraíba e } & \text { Taubaté (1645) } & \text { Taubaté } \\ \text { Litoral Norte } & & \text { Tietê } \\ \text { Alta Sorocabana } & \text { Tietê (1842) } & \text { Conchas (1916) } \\ \text { Alta Sorocabana } & & \text { Laranjal Paulista (1917) } \\ \text { Alta Sorocabana } & \text { Tremembé (1896) } & \text { Tremembé } \\ \text { Vale do Paraíba e } & & \text { Ubatuba } \\ \text { Litoral Norte } & \text { Ubatuba (1637) } & \text { Una (Ibiúna) } \\ \text { Vale do Paraíba e } & \text { Una (1857) }\end{array}$

Fontes: IBGE Cidades. Disponível em: https://cidades.ibge.gov.br/ Acesso em: 09 ago. 2019.

Nota: Entre parênteses, o nome atual da cidade e sua data de fundação. Os municípios da coluna "1920" estão colocados alinhados com os municípios de 1905 dos quais foram desmembrados. 
Anexo A2.2 - Destino dos imigrantes portugueses saídos da Hospedaria, São Paulo, 1886-1920, por região

\begin{tabular}{cccc}
\hline Região & $1886-1900$ & $1901-1920$ & Total \\
\hline Alta Sorocabana & 771 & 5.106 & 5.877 \\
Araraquarense & 712 & 5.749 & 6.461 \\
Baixa Sorocabana & 29 & 388 & 417 \\
Capital & 5.113 & 21.199 & 26.312 \\
Central & 1.910 & 3.646 & 5.556 \\
Mogiana & 4.512 & 15.020 & 19.532 \\
Noroeste & 10 & 2.075 & 2.085 \\
Paulista & 3.778 & 10.799 & 14.577 \\
Santos e Litoral Sul & 536 & 641 & 1.177 \\
Sorocaba & 86 & 566 & 652 \\
Vale do Paraíba e Litoral Norte & 272 & 996 & 1.268 \\
\hline Total & 17.729 & 66.185 & 83.914
\end{tabular}

Fonte: Registro de Matrícula da Hospedaria de Imigrantes, Memoria do Imigrante, Arquivo Público do Estado de São Paulo.

Nota: Os dados aqui apresentados não representam o total da nacionalidade que passou pela Hospedaria, dado que não foi possível mapear todas as saídas, em especial no período de 1886 a 1900.

Anexo A2.3 - Destino dos imigrantes italianos saídos da Hospedaria, São Paulo, 18861920, por região

\begin{tabular}{cccc}
\hline Região & $1886-1900$ & $1901-1920$ & Total \\
\hline Alta Sorocabana & 8.497 & 12.319 & 20.816 \\
Araraquarense & 12.345 & 22.227 & 34.572 \\
Baixa Sorocabana & 360 & 900 & 1.260 \\
Capital & 23.027 & 10.518 & 33.545 \\
Central & 26.794 & 11.538 & 38.332 \\
Mogiana & 38.801 & 45.597 & 84.398 \\
Noroeste & 380 & 2.959 & 3.339 \\
Paulista & 44.423 & 32.734 & 77.157 \\
Santos e Litoral Sul & 312 & 418 & 730 \\
Sorocaba & 1.117 & 1.029 & 2.146 \\
Vale do Paraíba e Litoral Norte & 2.529 & 1.732 & 4.261 \\
\hline Total & 158.585 & 14.1971 & 300.556
\end{tabular}

Fonte: Registro de Matrícula da Hospedaria de Imigrantes, Memoria do Imigrante, Arquivo Público do Estado de São Paulo.

Nota: Os dados aqui apresentados não representam o total da nacionalidade que passou pela Hospedaria, dado que não foi possível mapear todas as saídas, em especial no período de 1886 a 1900. 
Anexo A2.4 - Destino dos imigrantes espanhóis saídos da Hospedaria, São Paulo, 18861920, por região

\begin{tabular}{cccc}
\hline Região & $1886-1900$ & $1901-1920$ & Total \\
\hline Alta Sorocabana & 2.165 & 17.214 & 19.379 \\
Araraquarense & 2.734 & 26.987 & 29.721 \\
Baixa Sorocabana & 80 & 883 & 963 \\
Capital & 3.571 & 19.643 & 23.214 \\
Central & 3.666 & 13.604 & 17.270 \\
Mogiana & 5.683 & 42.688 & 48.371 \\
Noroeste & 41 & 3.612 & 3.653 \\
Paulista & 5.086 & 25.928 & 31.014 \\
Santos e Litoral Sul & 146 & 768 & 914 \\
Sorocaba & 140 & 1.075 & 1.215 \\
Vale do Paraíba e Litoral Norte & 314 & 1.744 & 2.058 \\
\hline Total & 23.626 & 154.146 & 177.772
\end{tabular}

Fonte: Registro de Matrícula da Hospedaria de Imigrantes, Memoria do Imigrante, Arquivo Público do Estado de São Paulo.

Nota: Os dados aqui apresentados não representam o total da nacionalidade que passou pela Hospedaria, dado que não foi possível mapear todas as saídas, em especial no período de 1886 a 1900.

Anexo A2.5 - Destino dos imigrantes alemães saídos da Hospedaria, São Paulo, 18861920, por região

\begin{tabular}{cccc}
\hline Região & $1886-1900$ & $1901-1920$ & Total \\
\hline Alta Sorocabana & 207 & 476 & 683 \\
Araraquarense & 145 & 643 & 788 \\
Baixa Sorocabana & 24 & 40 & 64 \\
Capital & 583 & 901 & 1.484 \\
Central & 319 & 241 & 560 \\
Mogiana & 276 & 448 & 724 \\
Noroeste & 0 & 127 & 127 \\
Paulista & 340 & 906 & 1.246 \\
Santos e Litoral Sul & 2 & 329 & 331 \\
Sorocaba & 2 & 27 & 29 \\
Vale do Paraíba e Litoral Norte & 9 & 64 & 73 \\
Total & 1.907 & 4.202 & 6.109
\end{tabular}

Fonte: Registro de Matrícula da Hospedaria de Imigrantes, Memoria do Imigrante, Arquivo Público do Estado de São Paulo.

Nota: Os dados aqui apresentados não representam o total da nacionalidade que passou pela Hospedaria, dado que não foi possível mapear todas as saídas, em especial no período de 1886 a 1900. 
Anexo A3.1 - Panorama das propriedades agrícolas de São Paulo, por nacionalidade, 1905

\begin{tabular}{|c|c|c|c|c|c|c|c|c|c|}
\hline & Total & Brasileiros & Estrangeiros & Italianos & Alemães & Portugueses & Espanhóis & Austríacos & Diversos \\
\hline Número de propriedades & 49.301 & 41.465 & 7.836 & 4.823 & 665 & 1.566 & 412 & 89 & 269 \\
\hline Área total (ha) & 4.741 .410 & 4.319 .977 & 421.433 & 153.737 & 59.116 & 131.341 & 10.036 & 4.118 & 61.506 \\
\hline Área cultivada (ha) & 582.036 & 505.076 & 76.960 & 34.104 & 10.499 & 19.436 & 2.899 & 646 & 9.298 \\
\hline Área em mata (ha) & 1.453 .668 & 1.302 .684 & 150.984 & 42.338 & 18.821 & 59.230 & 2.210 & 2.013 & 26.361 \\
\hline Área em capoeira (ha) & 1.000 .684 & 923.993 & 76.691 & 30.252 & 9.166 & 21.667 & 2.520 & 691 & 12.155 \\
\hline Área em pasto (ha) & 1.352 .732 & 1.241 .326 & 111.406 & 45.619 & 20.062 & 29.845 & 2.357 & 716 & 12.756 \\
\hline Área imprestável (ha) & 77.752 & 73.658 & 4.094 & 1.428 & 469 & 1.152 & 54 & 52 & 939 \\
\hline Propriedades produzindo café & 22.231 & 17.687 & 4.544 & 2.852 & 397 & 923 & 193 & 66 & 114 \\
\hline Propriedades produzindo algodão & 1.478 & 1.356 & 122 & 66 & 15 & 15 & 10 & 2 & 14 \\
\hline Propriedades produzindo cana & 6.797 & 5.501 & 1.296 & 875 & 80 & 210 & 61 & 20 & 48 \\
\hline Propriedades produzindo arroz & 16.730 & 14.066 & 2.664 & 1.612 & 274 & 476 & 165 & 33 & 104 \\
\hline Propriedades produzindo feijão & 28.666 & 24.994 & 3.672 & 2.222 & 321 & 707 & 240 & 54 & 127 \\
\hline Propriedades produzindo milho & 36.866 & 31.224 & 5.642 & 3.527 & 503 & 1.016 & 326 & 76 & 200 \\
\hline Área total em produção cafeeira (ha) & 347.081 & 295.543 & 51.538 & 21.438 & 7.661 & 13.838 & 1.621 & 400 & 6.516 \\
\hline Total de pés de café & 684.795 .205 & 585.577 .595 & 99.217 .610 & 42.253 .500 & 14.852 .818 & 27.608 .810 & 3.272 .187 & 800.555 & 10.303 .740 \\
\hline Produção cafeeira (arrobas) & 36.324 .161 & 31.121 .299 & 5.202 .862 & 2.016 .343 & 800.795 & 1.371 .177 & 150.935 & 36.130 & 819.782 \\
\hline Área total em produção cana (ha) & 18.810 & 14.103 & 4.708 & 2.131 & 452 & 700 & 99 & 50 & 1.275 \\
\hline Produção cana (arrobas) & 1.832 .843 & 1.126 .451 & 706.392 & 132.454 & 9.340 & 50.876 & 2.520 & 1.570 & 500.085 \\
\hline Produção aguardente (litros) & 68.155 .570 & 47.997 .425 & 20.158 .145 & 8.248 .725 & 2.117 .930 & 2.726 .060 & 541.810 & 101.500 & 6.432 .720 \\
\hline Área total em produção de algodão (ha) & 4.367 & 4.172 & 195 & 79 & 32 & 54 & 4 & 3 & 21 \\
\hline Produção total de algodão & 841.143 & 617.010 & 224.133 & 12.063 & 5.360 & 12.410 & 750 & 400 & 6.150 \\
\hline Área total em produção de arroz (ha) & 24.749 & 20.401 & 4.349 & 1.849 & 379 & 683 & 167 & 46 & 1.220 \\
\hline Produção total de arroz (litros) & 105.782 .944 & 88.543 .262 & 17.239.682 & 8.494 .552 & 1.349 .180 & 3.293 .720 & 842.130 & 165.400 & 3.072 .200 \\
\hline Área total em produção de milho (ha) & 160.557 & 141.683 & 18.875 & 8.624 & 2.258 & 4.387 & 744 & 204 & 2.624 \\
\hline
\end{tabular}


Produção total de milho (litros) Área total em produção de feijão (ha)

Produção total de feijão (litros)

Trabalhadores nacionais empregados

Trabalhadores estrangeiros empregados $\begin{array}{lllllllll}822.102 .800 & 722.635 .660 & 99.467 .140 & 48.084 .285 & 10.536 .200 & 24.438 .415 & 4.358 .820 & 1.051 .500 & 10.786 .720\end{array}$

$\begin{array}{lllllllll}61.643 & 53.603 & 8.041 & 3.154 & 1.112 & 1.666 & 347 & 103 & 1.658\end{array}$

$\begin{array}{lllllllll}113.128 .635 & 96.690 .536 & 16.438 .099 & 6.277 .898 & 2.206 .645 & 3.545 .798 & 785.910 & 224.450 & 3.393 .598\end{array}$

$\begin{array}{lllllllll}201.736 & 186.504 & 15.232 & 4.566 & 2.474 & 4.931 & 466 & 136 & 2.635\end{array}$

$\begin{array}{lllllllll}226.957 & 183.503 & 43.454 & 19.131 & 7.031 & 8.763 & 1.508 & 516 & 6.510\end{array}$

Fonte: São Paulo, Estatística Agrícola 1905. 
Anexo A3.2 - Produção por classe de propriedade e nacionalidade, São Paulo, 1905

\begin{tabular}{cccccc}
\hline Estrangeiros & Pequena & Média & Grande & Latifúndio & Total \\
\hline Área total alqueire & $51.089,87$ & $87.305,68$ & $109.023,39$ & $172.814,31$ & $420.233,25$ \\
Área cultivada & $20.430,65$ & $22.695,30$ & $21.226,12$ & $12.592,50$ & $76.944,57$ \\
alqueire & $900.015,00$ & $1.501 .850,00$ & $1.651 .150,00$ & $1.149 .300,00$ & $5.202 .315,00$ \\
Café arroba & $98.345,00$ & $59.309,50$ & $97.830,00$ & $450.713,00$ & $706.197,50$ \\
Cana arroba & $137.088,00$ & $76.955,00$ & $10.090,00$ & & $224.133,00$ \\
Algodão arroba & $6.187 .276,50$ & $5.414 .955,00$ & $2.798 .450,00$ & $2.839 .000,00$ & $17.239 .681,50$ \\
Arroz litro & $34.078 .080,00$ & $31.253 .120,00$ & $21.611 .640,00$ & $2.490 .000,00$ & $99.432 .840,00$ \\
Milho litro & $4.903 .209,00$ & $3.895 .860,00$ & $3.454 .400,00$ & $4.182 .780,00$ & $16.436 .249,00$ \\
Feijão litro & $\%$ peq-total & $\%$ med-total & $\%$ grande-total & $\%$ lat-total & \\
& $12,16 \%$ & $20,78 \%$ & $25,94 \%$ & $41,12 \%$ & 1 \\
\hline Área total alqueire & $26,55 \%$ & $29,50 \%$ & $27,59 \%$ & $16,37 \%$ & 1 \\
Área cultivada & $17,30 \%$ & $28,87 \%$ & $31,74 \%$ & $22,09 \%$ & 1 \\
alqueire & $13,93 \%$ & $8,40 \%$ & $13,85 \%$ & $63,82 \%$ & 1 \\
Café arroba & $61,16 \%$ & $34,33 \%$ & $4,50 \%$ & $0,00 \%$ & 1 \\
Cana arroba & $35,89 \%$ & $31,41 \%$ & $16,23 \%$ & $16,47 \%$ & 1 \\
Algodão arroba & $34,27 \%$ & $31,43 \%$ & $21,73 \%$ & $12,56 \%$ & 1 \\
Arroz litro & $29,83 \%$ & $23,70 \%$ & $21,02 \%$ & $25,45 \%$ & 1 \\
Milho litro & & & & & \\
Feijão litro & Mequena & Média & Grande & Latifúndio & Total \\
\cline { 2 - 6 } Brasileiros & $649.299,67$ & $1.286 .842,74$ & $1.877 .870,66$ & $4.029 .236,62$ \\
Área cultivada & $64.399,06$ & $129.543,61$ & $210.656,07$ & $95.014,69$ & $499.613,42$ \\
alqueire & $1.885 .759,50$ & $7.016 .027,00$ & $15.262 .592,50$ & $6.879 .802,00$ & $31.044 .181,00$ \\
Café arroba & $17.576 .188,00$ & $25.204 .690,00$ & $29.116 .432,00$ & $14.875 .850,00$ & $86.773 .160,00$ \\
Arroz litro & $15.223,56$ & $\%$ med-total & $\%$ grande-total & $\%$ lat-total & \\
Milho litro & $106.856 .838,00$ & $188.485 .522,00$ & $248.778 .790,00$ & $149.808 .400,00$ & $693.929 .550,00$ \\
Feijão litro & $17.582 .449,00$ & $24.119 .337,62$ & $33.635 .595,00$ & $20.362 .929,00$ & $95.700 .310,62$ \\
Área total & $16,11 \%$ & $31,94 \%$ & $46,61 \%$ & 1 \\
Café arroba & $6,07 \%$ & $22,60 \%$ & $49,16 \%$ & $22,16 \%$ & 1 \\
Arroz litro & $20,26 \%$ & $29,05 \%$ & $33,55 \%$ & $17,14 \%$ & 1 \\
Milho litro & $15,40 \%$ & $27,16 \%$ & $35,85 \%$ & $21,59 \%$ & 1 \\
Feijão litro & $18,37 \%$ & $25,20 \%$ & $35,15 \%$ & $21,28 \%$ & 1 \\
\hline Fonal & & & &
\end{tabular}

Fonte: São Paulo, Estatística Agrícola 1905. 
Anexo A3.3 - Participação da área cultivada com cada produto em relação à área cultivada total nas propriedades de estrangeiros, por região do estado de São Paulo, 1905

\begin{tabular}{cccccccc}
\hline & Café & Cana-de-açúcar & Algodão & Arroz & Milho & Feijão & Diversas \\
\hline Capital & $0,6 \%$ & $3,71 \%$ & $0,0 \%$ & $0,4 \%$ & $20,4 \%$ & $10,3 \%$ & $41,5 \%$ \\
Vale do Paraíba e & $53,6 \%$ & $6,87 \%$ & $0,0 \%$ & $6,4 \%$ & $21,4 \%$ & $13,2 \%$ & $4,0 \%$ \\
Litoral Norte & & & & & & & \\
Sorocaba & $10,9 \%$ & $6,47 \%$ & $8,8 \%$ & $4,3 \%$ & $46,7 \%$ & $12,6 \%$ & $7,5 \%$ \\
Central & $34,6 \%$ & $15,0 \%$ & $0,9 \%$ & $5,1 \%$ & $32,0 \%$ & $8,0 \%$ & $4,2 \%$ \\
Mogiana & $84,3 \%$ & $5,16 \%$ & $0,01 \%$ & $7,3 \%$ & $24,7 \%$ & $17,5 \%$ & $0,5 \%$ \\
Paulista & $69,7 \%$ & $5,38 \%$ & $0,0 \%$ & $4,7 \%$ & $26,5 \%$ & $11,5 \%$ & $0,6 \%$ \\
Araraquarense & $74,4 \%$ & $3,33 \%$ & $0,0 \%$ & $5,8 \%$ & $19,6 \%$ & $4,4 \%$ & $0,1 \%$ \\
Noroeste & $45,5 \%$ & $4,66 \%$ & $0,0 \%$ & $6,0 \%$ & $37,8 \%$ & $7,6 \%$ & $0,4 \%$ \\
Alta Sorocabana & $69,1 \%$ & $4,33 \%$ & $0,5 \%$ & $3,2 \%$ & $22,1 \%$ & $4,5 \%$ & $0,6 \%$ \\
Baixa Sorocabana & $50,6 \%$ & $0,87 \%$ & $5,9 \%$ & $6,3 \%$ & $36,0 \%$ & $5,3 \%$ & $2,4 \%$ \\
Santos e Litoral Sul & $24,9 \%$ & $1,52 \%$ & $0,0 \%$ & $6,1 \%$ & $1,9 \%$ & $1,0 \%$ & $2,9 \%$ \\
\hline Total Geral & $66,9 \%$ & $6,12 \%$ & $0,3 \%$ & $5,6 \%$ & $24,4 \%$ & $10,4 \%$ & $1,6 \%$ \\
\hline
\end{tabular}

Fonte: São Paulo, Estatística Agrícola 1905 
a) $\%$ propriedades rurais de estrangeiros por municipio, 1905

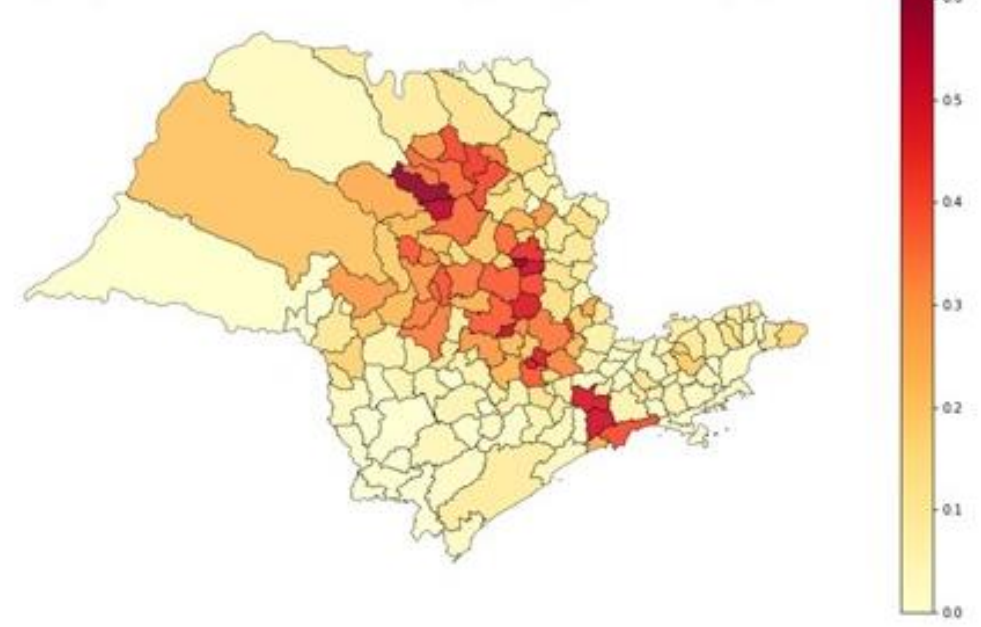

c) $\%$ área cultivada com milho, por municipio, 1905

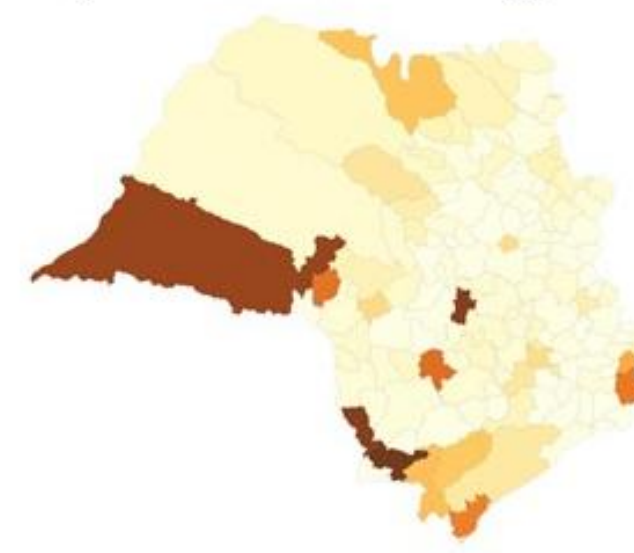

b) \% área cultivada com feijão, por municipio, 1905

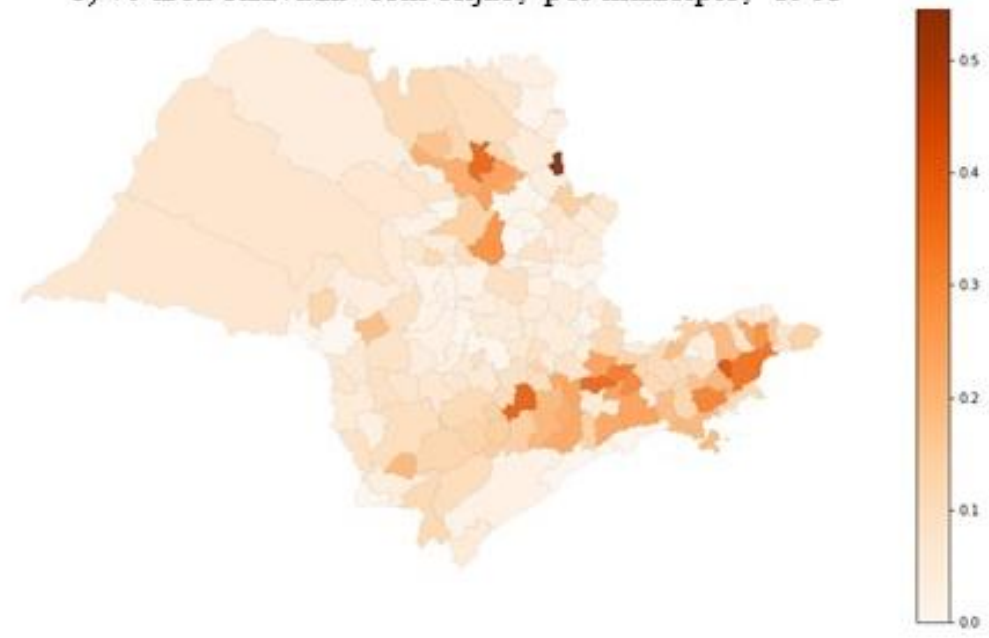

d) $\%$ área cultivada com arroz, por municipio, 1905

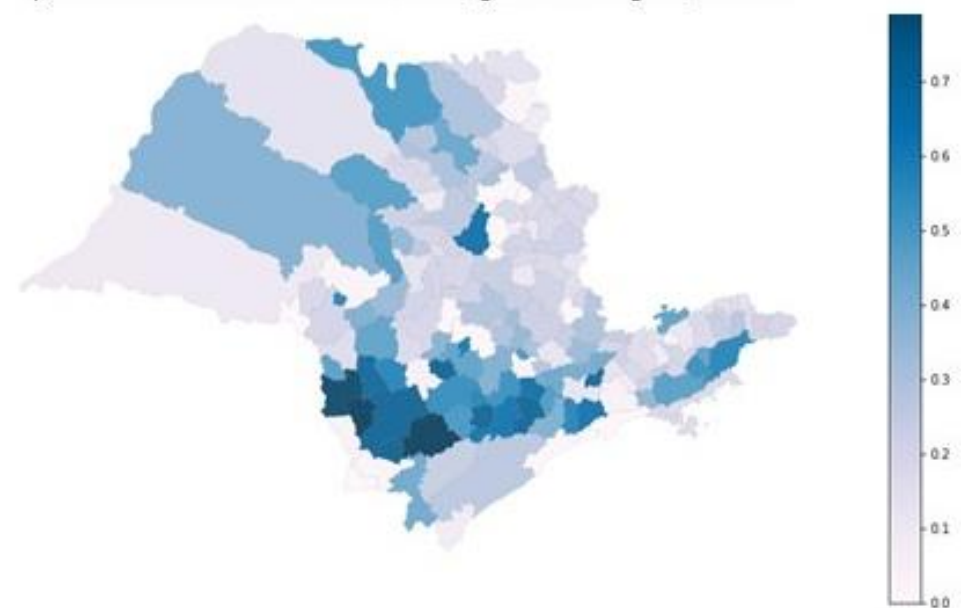

Anexo A3.3 - Mapas de localização de propriedades de estrangeiros e produção agrícola, 1905 Fonte: São Paulo, Estatística Agrícola. 
a) $\%$ propriedades rurais de estrangeiros por municipio, 1920

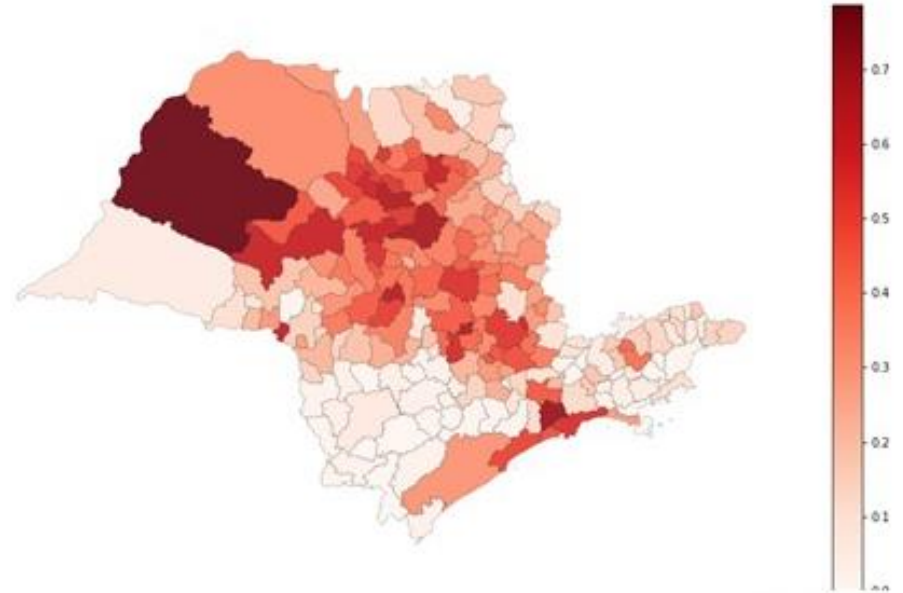

c) $\%$ área cultivada com milho, por municipio, 1920

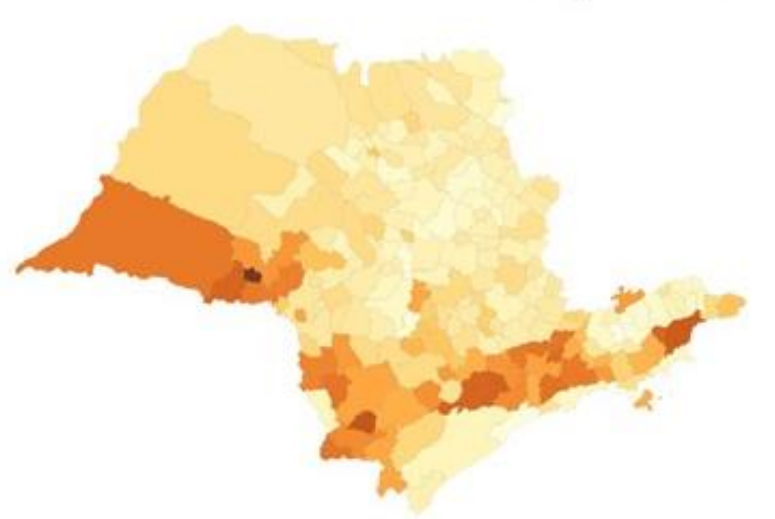

b) \% área cultivada com feijão, por municipio, 1920

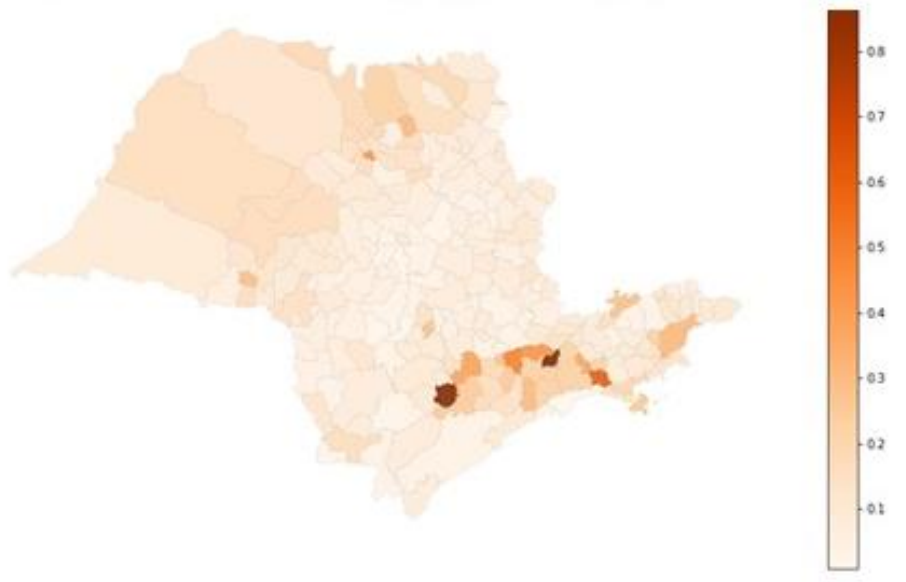

d) $\%$ área cultivada com arroz, por municipio, 1920

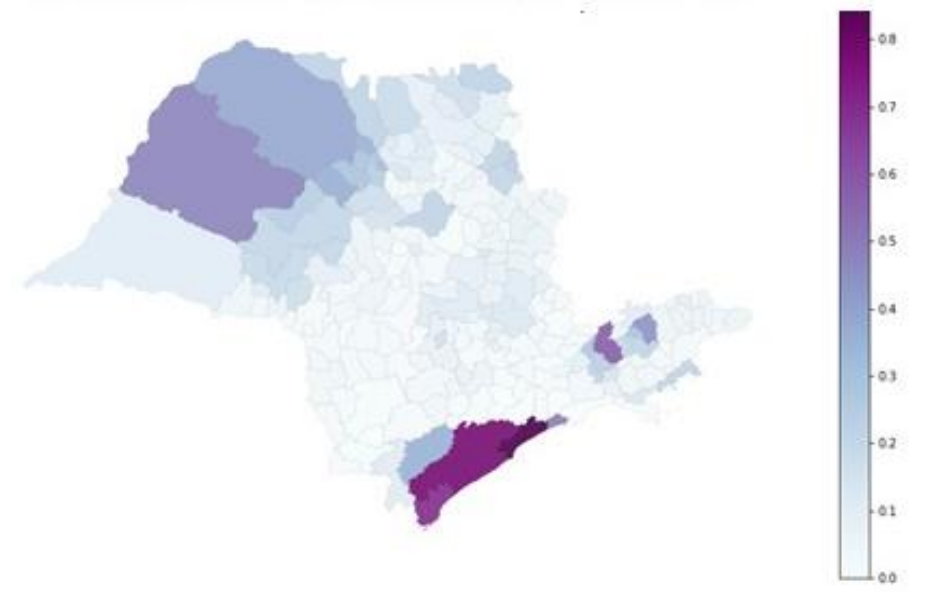

Anexo A3.4 - Mapas de localização de propriedades de estrangeiros e produção agrícola, 1920

Fonte: São Paulo, Estatística Agrícola. 
\% de Propriedades rurais de estrangeiros em São Paulo, 1905

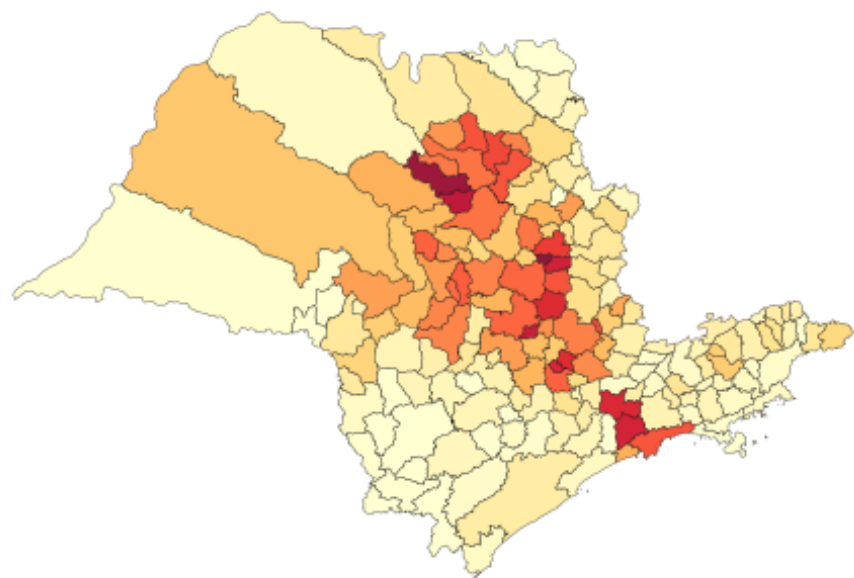

\% de Propriedades rurais de estrangeiros, por município, 1920

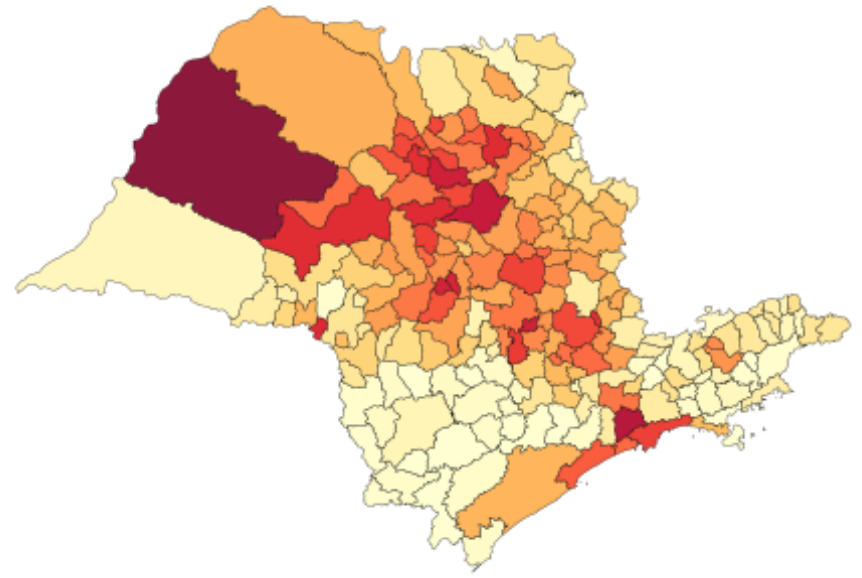

Participação do cafe na área cultivada, 1905

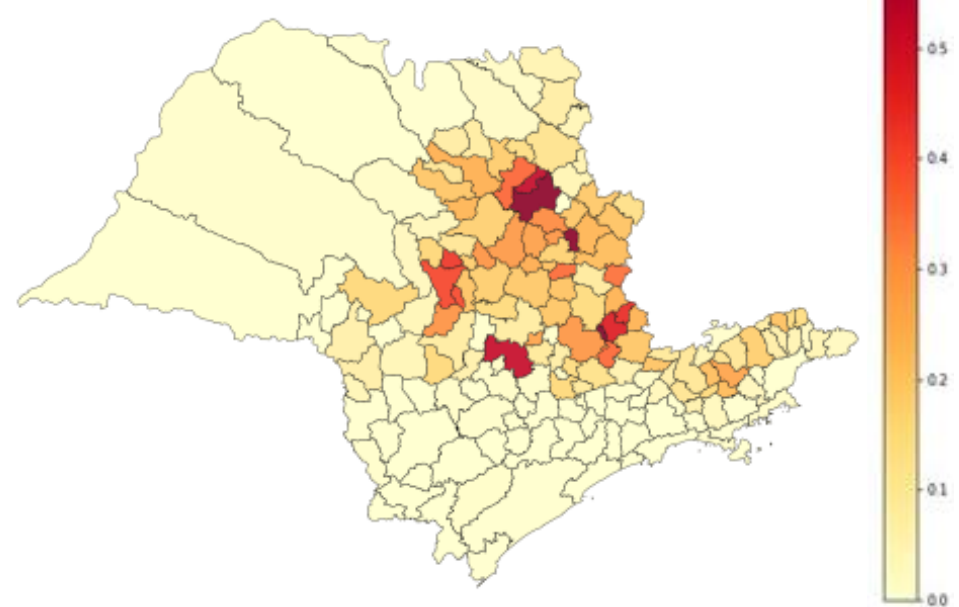

\% cafe na área total cultivada em 1919-1920

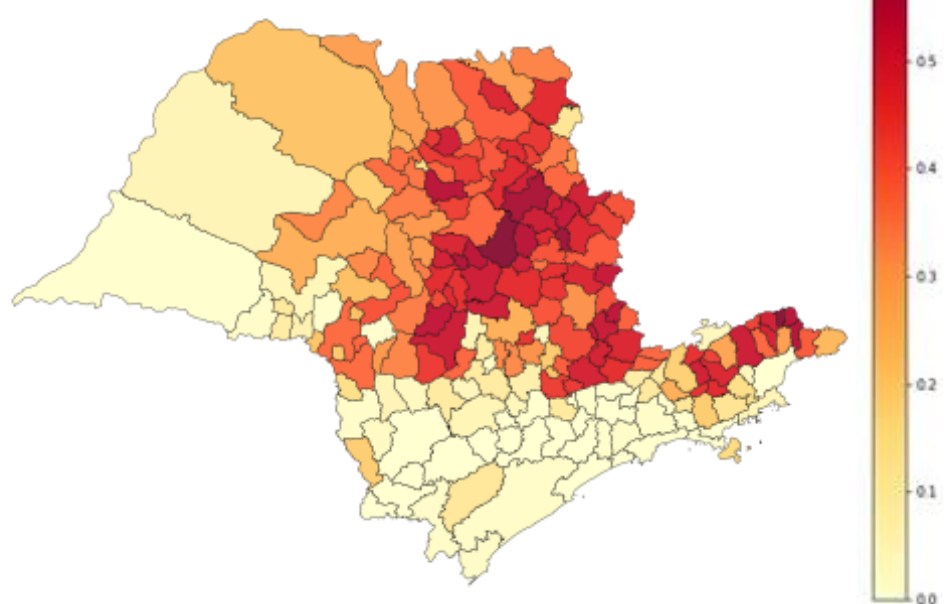

Anexo A3.5 - Mapas de localização de propriedades de estrangeiros e produção cafeeira em 1905 e 1920

Fonte: São Paulo, Estatística Agrícola. 